\title{
Development of the Town Data Base: Estimates of Exposure Rates and Times of Fallout Arrival Near the Nevada Test Site
}

Carol B. Thompson

Richard D. McArthur

Stan W. Hutchinson

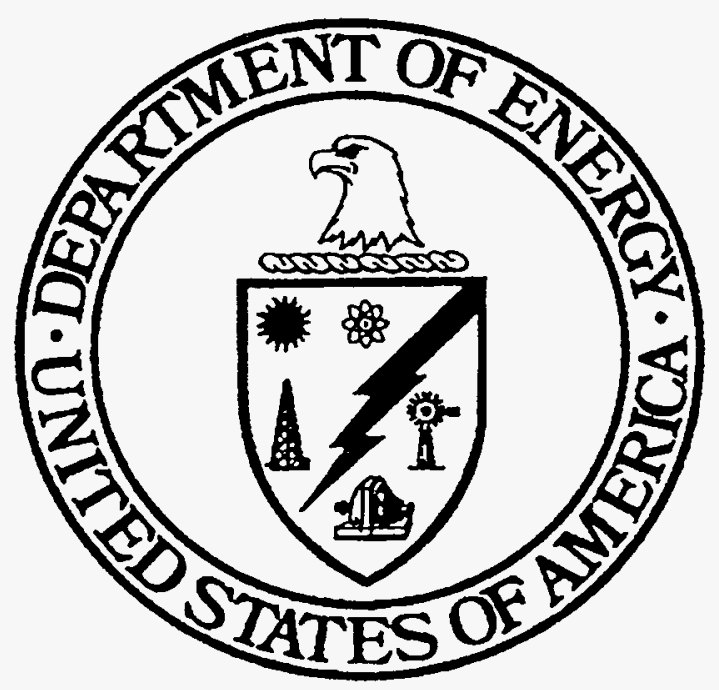

September 1994

U.S. Department of Energy

Nevada Operations Office

Las Vegas, Nevada 


\section{DISCLAIMER}

This report was prepared as an account of work sponsored by an agency of the United States Government. Neither the United States Government nor any agency thereof, nor any of their employees, make any warranty, express or implied, or assumes any legal liability or responsibility for the accuracy, completeness, or usefulness of any information, apparatus, product, or process disclosed, or represents that its use would not infringe privately owned rights. Reference herein to any specific commercial product, process, or service by trade name, trademark, manufacturer, or otherwise does not necessarily constitute or imply its endorsement, recommendation, or favoring by the United States Government or any agency thereof. The views and opinions of authors expressed herein do not necessarily state or reflect those of the United States Government or any agency thereof. 


\section{DISCLAIMER}

Portions of this document may be illegible in electronic image products. Images are produced from the best available original document. 


\title{
Development of the Town Data Base: Estimates of Exposure Rates and Times of Fallout Arrival Near the Nevada Test Site
}

\author{
by \\ Carol B. Thompson and Richard D. McArthur \\ Water Resources Center \\ Desert Research Institute \\ University and Community College System of Nevada \\ and \\ Stan W. Hutchinson \\ Mead Johnson Nutritional Group \\ Evansville, Indiana
}

Prepared for

Nevada Operations Office

U.S. Department of Energy

Las Vegas, Nevada

Under Contract Nos. DE-AC08-85NV10384 and DE-AC08-90NV10845

September 1994

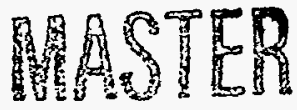

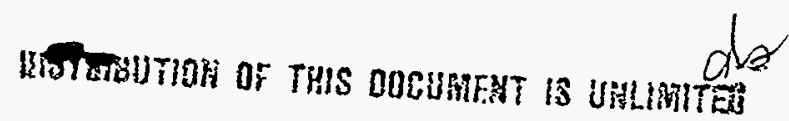




\title{
Development of the Town Data Base: \\ Estimates of Exposure Rates and Times of Fallout Arrival Near the Nevada Test Site*
}

\author{
Carol B. Thompson and Richard D. McArthur \\ Water Resources Center, Desert Research Institute \\ University and Community College System of Nevada \\ P.O. Box 19040, Las Vegas, Nevada 89132-0040 \\ and \\ Stan W. Hutchinson \\ Mead Johnson Nutritional Group \\ Evansville, Indiana 47721
}

KEY WORDS: ORERP; exposure rate; fallout arrival time; dose assessment

\begin{abstract}
As part of the U.S. Department of Energy's Off-Site Radiation Exposure Review Project, the time of fallout arrival and the $\mathrm{H}+12$ exposure rate were estimated for populated locations in Arizona, California, Nevada, and Utah that were affected by fallout from one or more nuclear tests at the Nevada Test Site. Estimates of exposure rate were derived from measured values recorded before and after each test by fallout monitors in the field. The estimate for a given location was obtained by retrieving from a data base all measurements made in the vicinity, decay-correcting them to $\mathrm{H}+12$, and calculating an average. Estimates were also derived from maps produced after most events that show isopleths of exposure rate and time of fallout arrival. Both sets of isopleths on these maps were digitized, and kriging was used to interpolate values at the nodes of a $10-\mathrm{km}$ grid covering the pattern. The values at any location within the grid were then estimated from the values at the surrounding grid nodes. Estimates of dispersion (standard deviation) were also calculated. The Town Data Base contains the estimates for all combinations of location and nuclear event for which the estimated mean $\mathrm{H}+12$ exposure rate was greater than three times background. A listing of the data base is included as an appendix. The information was used by other project task groups to estimate the radiation dose that off-site populations and individuals may have received as a result of exposure to fallout from Nevada nuclear tests.
\end{abstract}

*The work upon which this report is based was supported by the U.S. Department of Energy under Contracts DE-AC08-85NV10384 and DE-AC08-90NV10845. 


\section{CONTENTS}

ABSTRACT $\ldots \ldots \ldots \ldots \ldots \ldots \ldots \ldots \ldots \ldots \ldots \ldots \ldots \ldots \ldots \ldots \ldots \ldots \ldots$

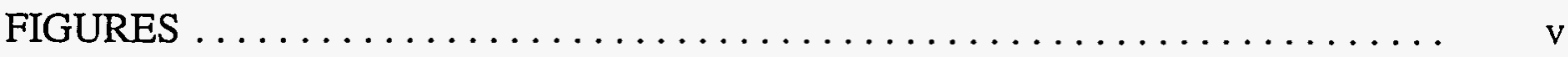

TABLES $\ldots \ldots \ldots \ldots \ldots \ldots \ldots \ldots \ldots \ldots \ldots \ldots \ldots \ldots \ldots \ldots$

ACKNOWLEDGMENTS $\ldots \ldots \ldots \ldots \ldots \ldots \ldots \ldots \ldots \ldots \ldots \ldots$ vi

1. INTRODUCTION $\ldots \ldots \ldots \ldots \ldots \ldots \ldots \ldots \ldots \ldots \ldots \ldots \ldots \ldots \ldots$

2. OVERVIEW OF THE METHODOLOGY $\ldots \ldots \ldots \ldots \ldots \ldots \ldots \ldots \ldots$

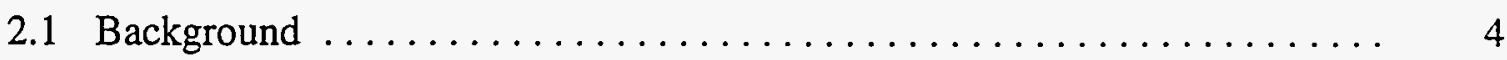

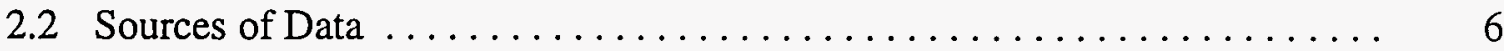

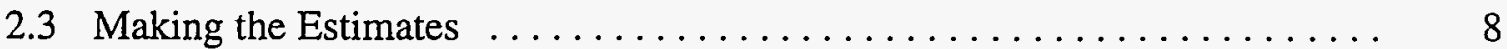

2.4 The Town Data Base ............................ 9

3. ESTIMATES FROM FALLOUT PATTERNS $\ldots \ldots \ldots \ldots \ldots \ldots \ldots \ldots \ldots$

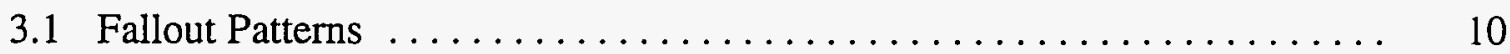

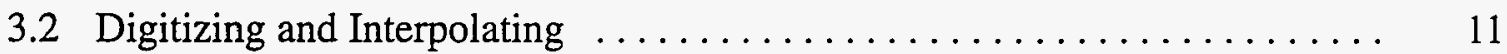

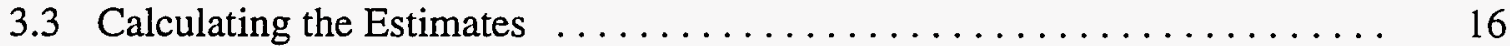

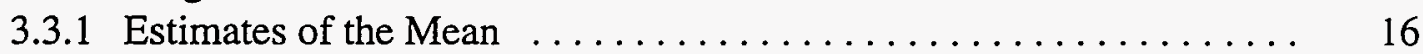

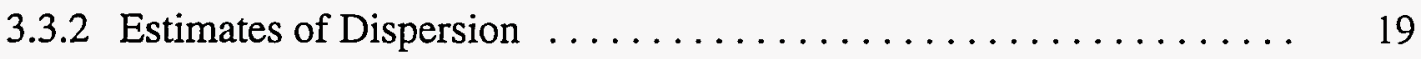

4. ESTIMATES FROM SURVEY METER DATA . . . . . . . . . . . . . . 20

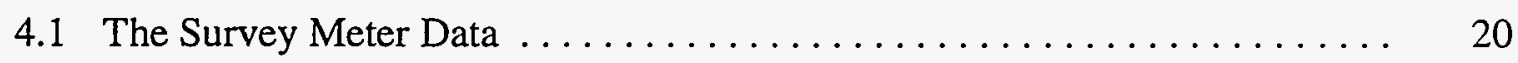

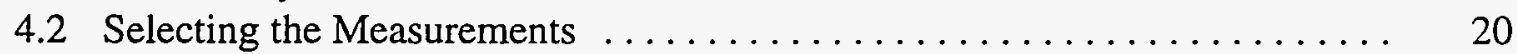

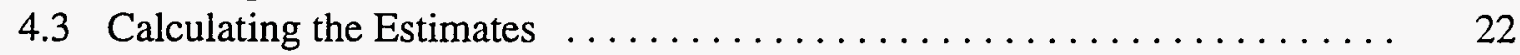

5. CREATING AND REVIEWING THE ESTIMATES . . . . . . . . . . . 25

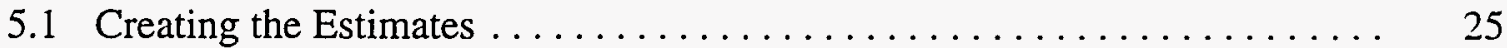

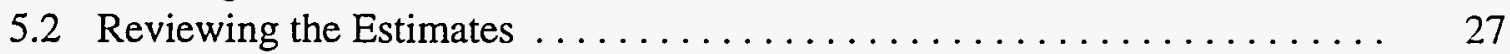

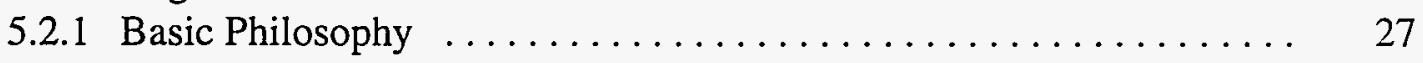

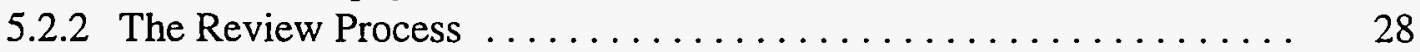

5.2 .3 Criteria for Review ....................... 31

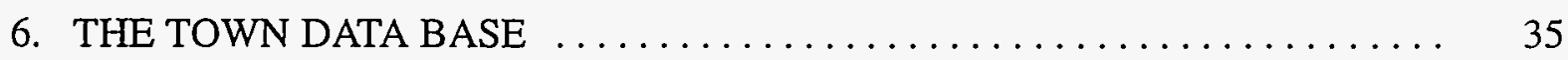

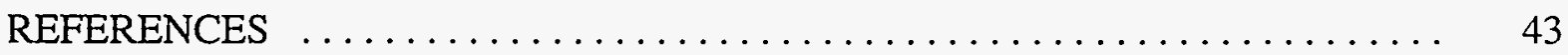

\section{APPENDICES}

Appendix A. Locations Considered for the Town Data Base . . . . . . . . 47

Appendix B. Record Format for the Town Data Base .............. 63

Appendix C. Selected Information from the Town Data Base . . . . . . . 67

Appendix D. Project Directive No. $10 \ldots \ldots \ldots \ldots \ldots \ldots \ldots \ldots \ldots \ldots$ 


\section{FIGURES}

1. The ORERP Phase I and Phase II regions $\ldots \ldots \ldots \ldots \ldots \ldots \ldots \ldots \ldots \ldots \ldots$

2. Typical form of an exposure rate profile $\ldots \ldots \ldots \ldots \ldots \ldots \ldots \ldots \ldots \ldots$

3. Isopleths of $\mathrm{H}+12$ exposure rate and time of fallout arrival from event EASY $\ldots 7$

4. Generalized flow diagram of the estimation process $\ldots \ldots \ldots \ldots \ldots \ldots \ldots .8$

5. Points of the 10-km grid superimposed on the fallout pattern from event EASY . $\quad 13$

6. Part of the EASY fallout pattern showing the interpolated exposure rates

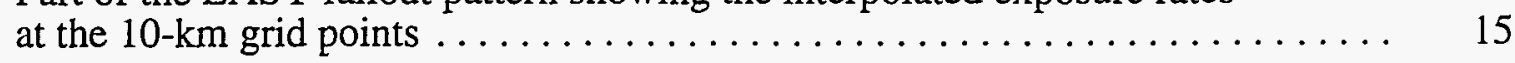

7. Situations where estimates can be calculated from the $10-\mathrm{km}$ grid $\ldots \ldots \ldots \ldots 18$

8. Locations at which survey meter data were collected for event HARRY $\ldots \ldots \quad 21$

9. Flow diagram of the FATHER procedure $\ldots \ldots \ldots \ldots \ldots \ldots \ldots \ldots \ldots \ldots .26$

10. Flow diagram of the post-FATHER procedure $\ldots \ldots \ldots \ldots \ldots \ldots \ldots \ldots .30$

11. The Decision Tracking Sheet used to document the review of the estimates $\ldots . .32$

12. Locations for which estimates were attempted $\ldots \ldots \ldots \ldots \ldots \ldots \ldots \ldots, 36$

13. Locations for which the Town Data Base contains estimates $\ldots \ldots \ldots \ldots \ldots$

TABLES

1. Case Letters Assigned to Estimates from Survey Meter Data ............ 29

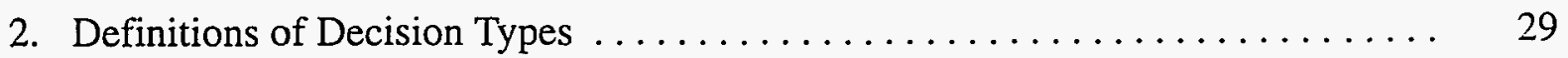

3. Distribution of Locations Used to Create the Town Data Base ........... 38

4. Events Used to Create the Town Data Base $\ldots \ldots \ldots \ldots \ldots \ldots \ldots \ldots \ldots$ 


\section{ACKNOWLEDGEMENTS}

Any project of this size could only be completed with the help of many people along the way. We would like to express our appreciation to our colleagues at the Desert Research Institute who helped make the road smoother, especially Jody Giacomini, who participated in the early development of the estimation process; Walter Lombardo, who helped in the early days with digitizing and processing the fallout maps; Gail Lucas, who provided the programming and data base update support for several major revisions of the Town Data Base from 1985 through the present; and Debi Noack, Karen Gray, Jerry Carter, and Rebecca Gardiner, who provided electronic publishing and graphics support for this and related documents. We also thank Martha DeMarre, John Harney, and Sheryl Pfeuffer of Reynolds Electrical \& Engineering Co., Inc., for their assistance in retrieving information and documents and checking estimates, and Dr. Lynn Anspaugh of Lawrence Livermore National Laboratory for providing historical and technical insights during the review of the estimates. 


\section{INTRODUCTION}

The Nevada Test Site (NTS) has been used as a testing area for nuclear weapons since 1951. More than 100 above-ground nuclear tests took place there before the Limited Test Ban Treaty banned atmospheric testing in 1963, and many of those tests, as well as a few subsurface tests, released radioactivity that was detected off-site (that is, beyond the boundaries of the NTS and the adjacent Nellis Air Force Range).

Protecting the public from exposure to radioactive fallout was a primary factor in choosing a remote desert location such as the NTS for nuclear testing, and it has always been an important element of the testing program. Radiation levels were (and still are) monitored routinely during and after every nuclear test. Before each atmospheric test, monitors were stationed on highways and in towns downwind of the NTS to record radiation levels in the hours before and after detonation. Other monitors in aircraft tracked the fallout cloud visually and with instruments until it dispersed. Occasionally residents were warned to stay indoors during passage of a fallout cloud, but the measured amounts of radiation were generally below the levels then considered hazardous to human health.

Nevertheless, public concerns about the effects of NTS fallout has continued at various levels since testing began. In the late 1970s, publicity about the number of leukemia cases in observers of the 1957 SMOKY test led to numerous claims against the government seeking compensation for health problems that might have been caused by fallout. In response to these claims and to many inquiries from Congress and the general public, the U.S. Department of Energy began the Off-Site Radiation Exposure Review Project (ORERP) in 1979.

The ORERP had two objectives. The first was to collect and organize at one central location all available documents and data pertaining to fallout in the off-site area and make this information accessible to the public. This objective was met through the development of the Coordination and Information Center, an archive of more than 250,000 documents on off-site fallout and related subjects.

The second objective was to reevaluate the radiation dose that off-site residents received from nuclear testing at the NTS, based on their age, occupation, and place of residence. The dose evaluation required the collective scientific expertise of several Department of Energy laboratories and contractors, which were assigned various tasks as follows:

- Data Collection - to identify and collect historical fallout measurements and other information necessary for dose evaluation (Reynolds Electrical \& Engineering Co., Inc., History Associates, Inc., and Holmes and Narver, Inc.).

- Fallout Verification - to create computer files containing the historical fallout data (Environmental Monitoring Systems Laboratory, U.S. Environmental Protection Agency [EPA-EMSL]) and to reevaluate fallout patterns (Weather Service Nuclear Support Office [WSNSO], National Oceanic and Atmospheric Administration).

- Data Analysis - to provide data analysis, quality assurance, and statistical support to the other task groups (Desert Research Institute, University and Community College System of Nevada).

- Pathway Analysis - to develop models for the transport of radionuclides from their deposition on the ground to ingestion by humans (Colorado State University). 
- Internal Dose - to develop estimates of organ doses resulting from ingestion and inhalation of fallout radionuclides (Lawrence Livermore National Laboratory).

- External Dose - to develop estimates of organ doses resulting from fallout radionuclides external to the body (Los Alamos National Laboratory).

The general role of the first three task groups was to provide information required as input to computer models developed by the last three task groups. The computer models could then be used to produce an estimate of radiation dose to populations or individuals based on information about residence and lifestyle histories. The original intent was to formalize this process into an Individual Dose Assessment model that would be available to the public. Reduced funding in the later years of the ORERP left the model incomplete; instead, the completed modules remain in the custody of the separate task groups to be activated as needed.

The work of the ORERP was overseen by an independent panel of physicians and scientists, the Dose Assessment Advisory Group, that met regularly to review the methods and results of the task groups. Additional information about the scope and methods of the ORERP can be found in Friesen (1985) and Church et al. (1990).

The goal of the dose assessment effort was to be able to estimate the radiation dose received by any person living in an area where fallout from the NTS was deposited. More than 70 nuclear events at the NTS caused off-site fallout, and more than 300 populated areas in Nevada and neighboring states received fallout from at least one event. To get results that were as accurate as possible, the radiation dose had to be calculated separately for each combination of event and populated area.

Ideally, the dose calculations would be based on the total external radiation exposure and the levels of radiation in the air, food, and water consumed by residents of the affected areas in the days and weeks after an event. Unfortunately, few such measurements were made in the 1950 s, the decade in which most fallout from the NTS occurred. What was measured on a routine basis was the rate of external exposure to gamma radiation. The ORERP scientists therefore decided to base their calculations on the large amount of historical data on exposure rates in the off-site region.

Most of the historical data are not in a form that can be used directly in the ORERP dose-estimation models. Instead, the data were used to estimate two intermediate quantities for every location that was affected by a given event: the time that the fallout cloud arrived and the exposure rate 12 hours after detonation. Such estimates were made for every nuclear event that resulted in measured off-site fallout and for every populated location that might have received fallout from at least one event. The estimates for locations that received a discernible amount of fallout from an event were entered into the Town Data Base for use in dose calculations.

The original focus of the dose evaluation was on the area considered to be most heavily affected by NTS fallout: Clark, Esmeralda, Lincoln, and Nye counties in Nevada and Washington County in Utah. The Town Data Base contains the estimates of arrival time and exposure rate for locations in this area, the Phase I region. Later, the ORERP scientists addressed the possibility that significant exposure might have occurred farther downwind from the NTS, and defined a Phase II region surrounding the Phase I region (Figure 1). The County Data Base contains the estimates for the Phase II region. It is similar in format to the Town Data Base although the methods used to create it were completely different (Beck and Anspaugh, 1991). 

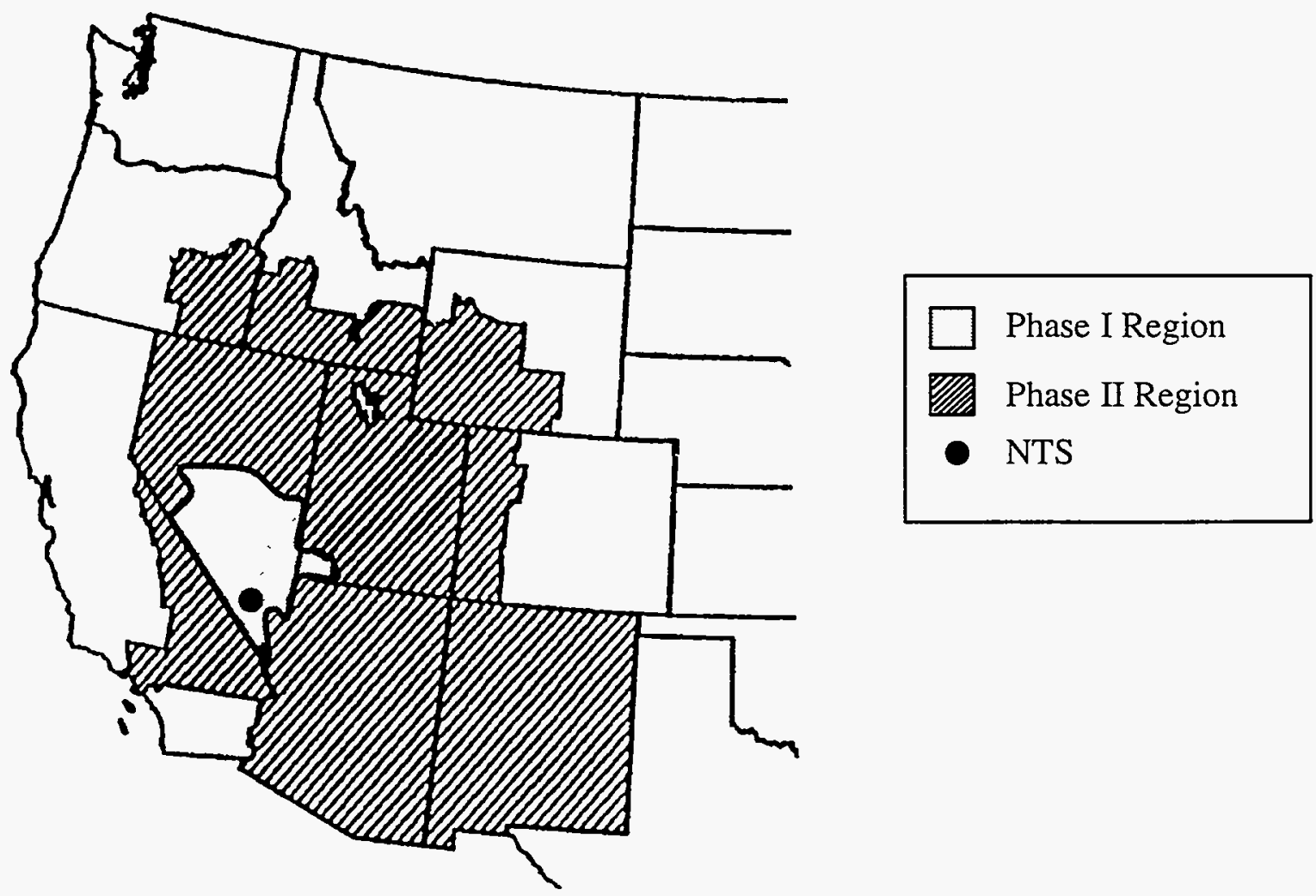

Figure 1. The ORERP Phase I and Phase II regions (adapted from Beck and Anspaugh, 1991).

This report describes in detail the methods used to create the Town Data Base. Its primary purpose is to document the process for scientists who may need to understand exactly how the estimates were derived. We recognize, however, that the subject of NTS fallout is of some interest to people outside the scientific community. We have therefore tried to provide in Section 2 more background information and a general outline of the estimation process at a level that can be understood by readers with a limited scientific background. Sections 3 and 4 cover the technical aspects of how the estimates were produced. Section 5 describes the computer programs used to create the estimates and the thorough review and quality assurance assessment given to the estimates before they were included in the data base. Finally, Section 6 describes the contents of the Town Data Base and provides some summary statistics. A complete listing of the estimates in the Town Data Base, sorted by location and event, is included in the appendices. 


\section{OVERVIEW OF THE METHODOLOGY}

\subsection{BACKGROUND}

A full explanation of how doses are calculated from exposure rates is beyond the scope of this report. For present purposes, it suffices to note that one important quantity in the calculations is the total exposure to gamma radiation at a given location resulting from a given event. The traditional unit of exposure, in the technical sense of the word, is the roentgen (R). In recent years the roentgen has been replaced by a new unit, coulomb $/ \mathrm{kg}(=3,876 \mathrm{R})$, but in keeping with the historical context of the data, we will use roentgens (more precisely, thousandths of a roentgen, $\mathrm{mR}$ ) in this report.

Relatively few direct measurements of exposure were made during the period of atmospheric testing. The instruments used by the radiation monitors measured the exposure rate, usually in milliroentgens per hour $(\mathrm{mR} / \mathrm{h})$. If the exposure rate is constant, the exposure can be calculated by multiplying the exposure rate by the duration of exposure. However, when a fallout cloud moves over a location, the exposure rate is constantly changing. It is at some background level until the fallout cloud arrives, then increases rapidly as the cloud passes over. Once the cloud has moved on, the exposure rate begins to decrease as a result of radioactive decay and, to a lesser extent, weathering of the radioactive particles into the soil. A graphical profile of exposure rate as a function of time typically has the form shown in Figure 2.

The exposure can be calculated from an exposure rate profile: It is the area under the curve from the time the fallout cloud arrives until the exposure rate returns to the background level. Once again, however, only in a few instances were enough data collected at one location for an exposure rate profile to be drawn. Usually an approximate profile, indicated by a dashed line in Figure 2, has to be used. The approximate profile is one that would result from an instantaneous arrival of fallout. If the time of fallout arrival (TA) is defined so the area under the true profile before TA (area A in Figure 2) is equal to the area between the true and approximate profiles after TA (area B), the exposures computed from the two profiles are equal.

Drawing an approximate profile requires three pieces of information: the time of fallout arrival, the exposure rate at one point in time after fallout arrival, and a function describing the decay of exposure rate over time. Determining these three quantities was therefore a crucial part of the dose evaluation project. This report describes how values were produced for two of these quantities, the time of fallout arrival and the exposure rate. (The third quantity, the decay function, received much attention in the early days of the ORERP. The initial calculations used a " $t^{-1.2}$ power curve" model based on earlier fallout studies. That model was determined to be too inaccurate (Anspaugh, 1981), although it was still used as an approximation in some situations. A more accurate decay function, the "sum of 11 exponentials" model, was later developed from the data of Hicks (1981) by the External Dose task group (Henderson and Smale, 1990).)

In principle, a measurement of exposure rate at any time after fallout arrival could be used in determining an exposure rate profile. However, the dose calculations are greatly simplified if the same point in time is used for all the profiles. The reference time chosen was 12 hours after detonation $(\mathrm{H}+12)$. This choice allowed comparison of the ORERP results with those of earlier studies, most of which also used $\mathrm{H}+12$ values. Unless otherwise noted, all references to calculated exposure rates mean the value at $\mathrm{H}+12$.

At this point, a complication arises because neither the time of fallout arrival nor the $\mathrm{H}+12$ exposure rate can be determined with absolute certainty. For example, the use of different kinds of 


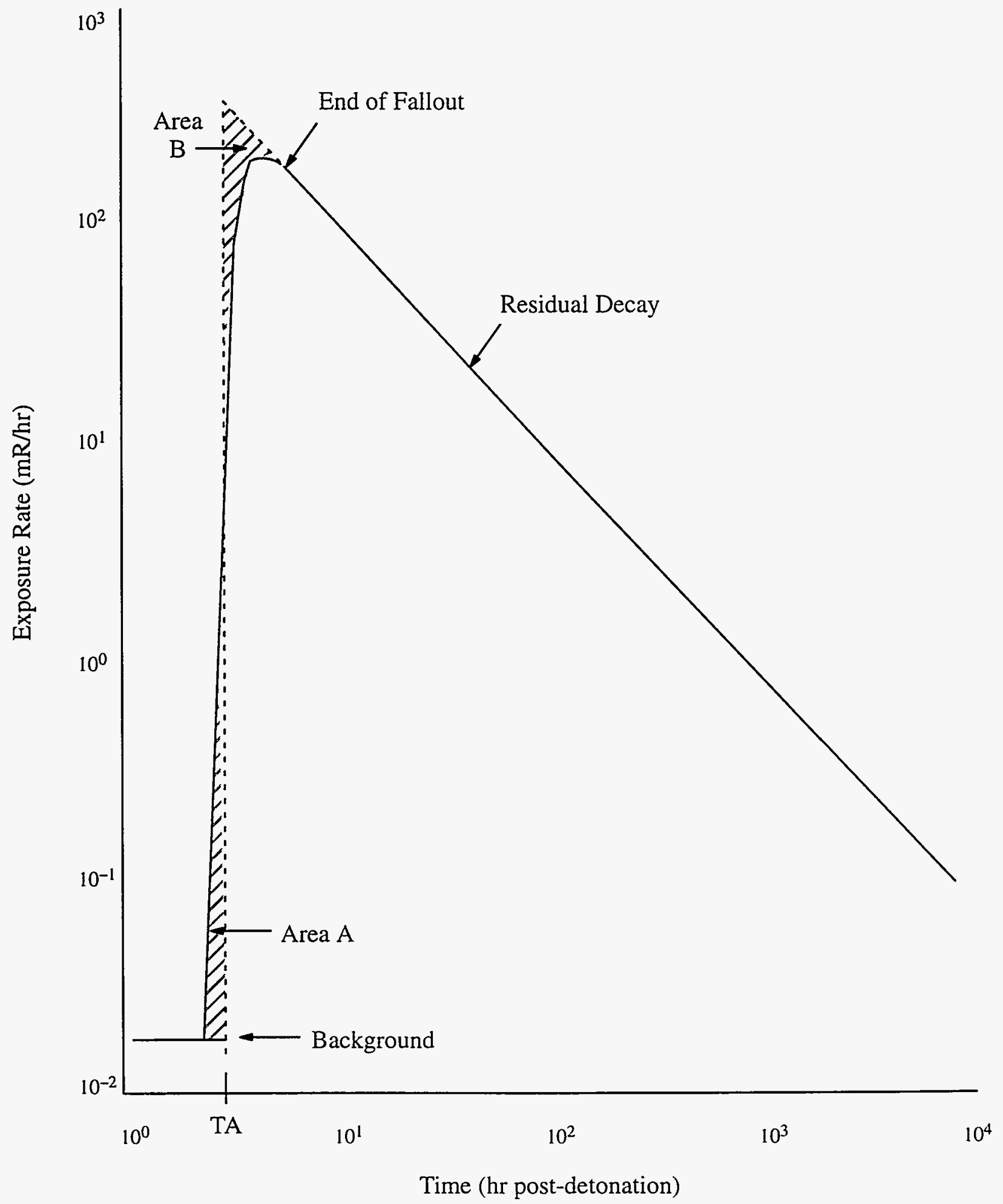

Figure 2. Typical form of an exposure rate profile. 
monitoring instruments, small-scale variations in weather conditions, and numerous other factors will cause variation in the measurements of exposure rate even after they are all decay-corrected to $\mathrm{H}+12$. The best that can be done is to compute an average value, which presumably will be close to the "true" value but which will always be accompanied by some degree of uncertainty.

Such uncertainties in the values of the input parameters will resuit in uncertainty in any calculated doses. The computer models used to calculate dose take these uncertainties into account, and compute a most probable dose or range of doses rather than a single definitive value. To enable the uncertainty in the calculated values of arrival time and exposure rate to be incorporated into the final dose estimates, the estimates of both quantities were assumed to have a particular probability distribution with some mean (a measure of central tendency) and standard deviation (a measure of dispersion about the mean). The estimates of time of fallout arrival were assumed to have a normal distribution, characterized by the arithmetic mean $X_{T}$ and standard deviation $S_{T}$. The estimates of exposure rate were assumed to have a lognormal distribution, characterized by the geometric mean $X_{E}$ and geometric standard deviation $S_{E}$.

The task at hand can therefore be summarized as follows: To estimate, from historical data on fallout deposition, the mean and standard deviation of the time of fallout arrival and the (geometric) mean and standard deviation of the $\mathrm{H}+12$ exposure rate for every populated area near the NTS that received fallout from an NTS event.

\subsection{SOURCES OF DATA}

Two major sources of information on fallout deposition were available: survey meter readings taken by monitors in the field and published maps showing patterns of fallout distribution.

The largest single body of data was the set of some 119,000 radiation measurements taken before and after each of more than 200 nuclear events by monitors who were trained in fallout survey techniques. Typically, monitors were stationed at numerous locations in towns and along roads, especially in the projected trajectory of fallout. They used portable instruments such as geiger counters and ion chambers to measure, for the most part, the external gamma exposure rate at three feet $(1 \mathrm{~m})$ above the ground. As the measurements were taken, the monitors recorded on log sheets the time and place, the instrument type, the gross radiation reading and a previously determined background level, and comments about the measurements or weather conditions. The logs were later evaluated along with other data to determine the extent of the fallout deposition and maximum readings, to prepare maps showing the distribution of fallout, and to estimate external exposures to residents of the affected areas. The results were usually written up as off-site surveillance or radiation safety reports, such as the ones by Collison (1953) and Placak (1962).

In the 1980 s, the log sheets were retrieved from storage and and the information in them was evaluated and computerized by EPA-EMSL. The resulting data file, the Survey Meter Data Base, is described in Grossman and Thompson (1993).

Fallout patterns were produced for 77 events in the 1950 s and 1960 s, primarily by the U.S. Weather Bureau. The patterns were based on the survey meter readings and the prevailing weather conditions at the time of the event. Most of the fallout patterns show isopleths of both exposure rate $(\mathrm{H}+12$, usually) and time of fallout arrival. An example is shown in Figure 3. As part of the ORERP, the WSNSO reanalyzed the patterns for 11 events using additional data (Quinn, 1990). 


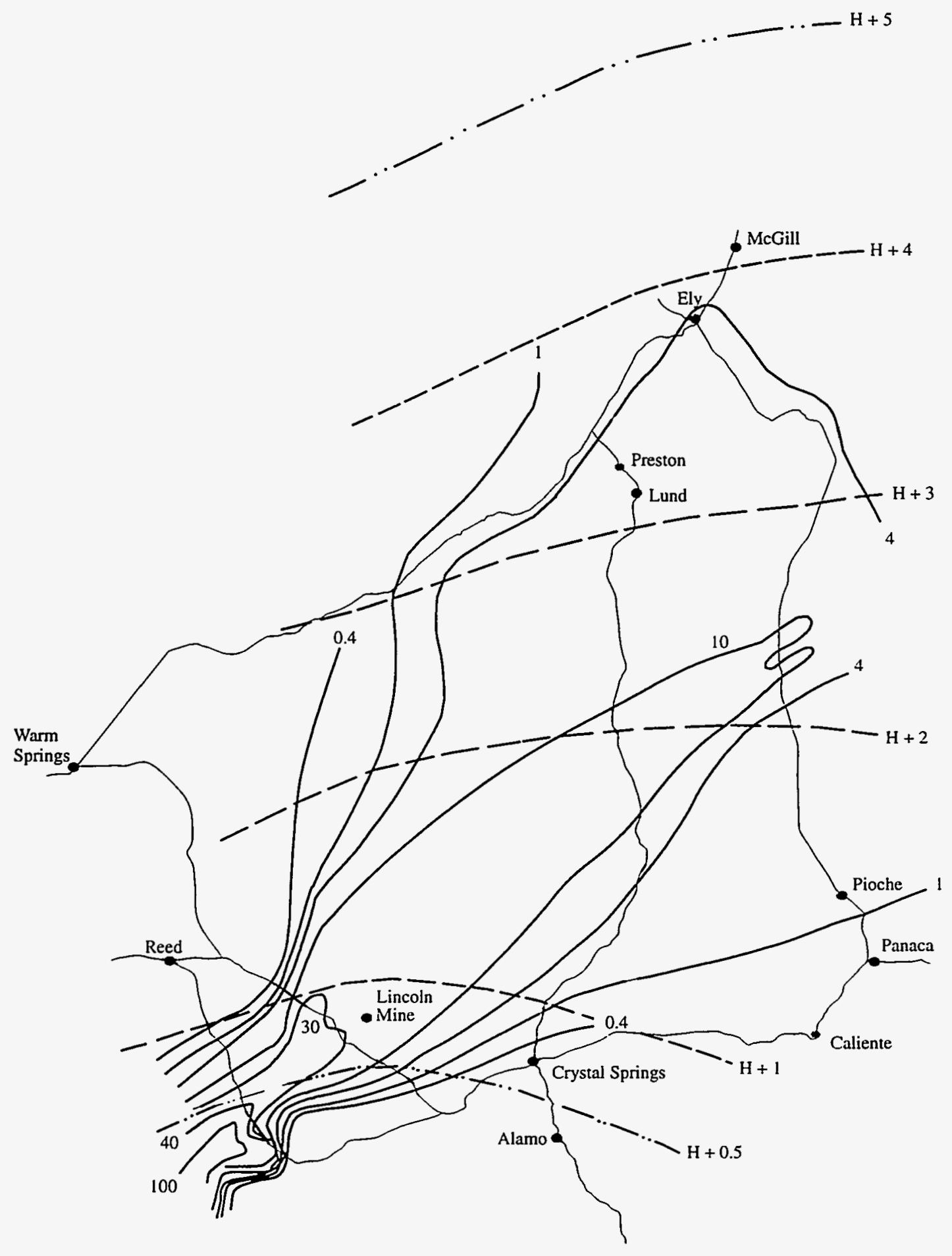

Figure 3. Isopleths of $\mathrm{H}+12$ exposure rate $(\mathrm{mR} / \mathrm{hr}$; solid lines) and time of fallout arrival ( $\mathrm{H}+$ hours; dashed lines) from event EASY. The $\mathrm{H}+0.5$ and $\mathrm{H}+5$ isopleths were added to the original map to aid in interpolation (see Section 3.1). Redrawn and modified from Quinn et al. (1986). 


\subsection{MAKING THE ESTIMATES}

At the start of the ORERP, a committee developed a list of 604 sites in Nevada, Utah, Arizona, and California that were considered populated areas and might have been affected by nuclear events at the NTS (Appendix A). All the sites were used in making and reviewing estimates, although not all of them are represented in the Town Data Base.

Estimates were produced separately from the survey meter data and the fallout patterns. If estimates for a given location and event were obtained from both sources, they were compared at the end of the process to determine which would be placed in the data base. Figure 4 shows a generalized flow diagram of the estimation process.

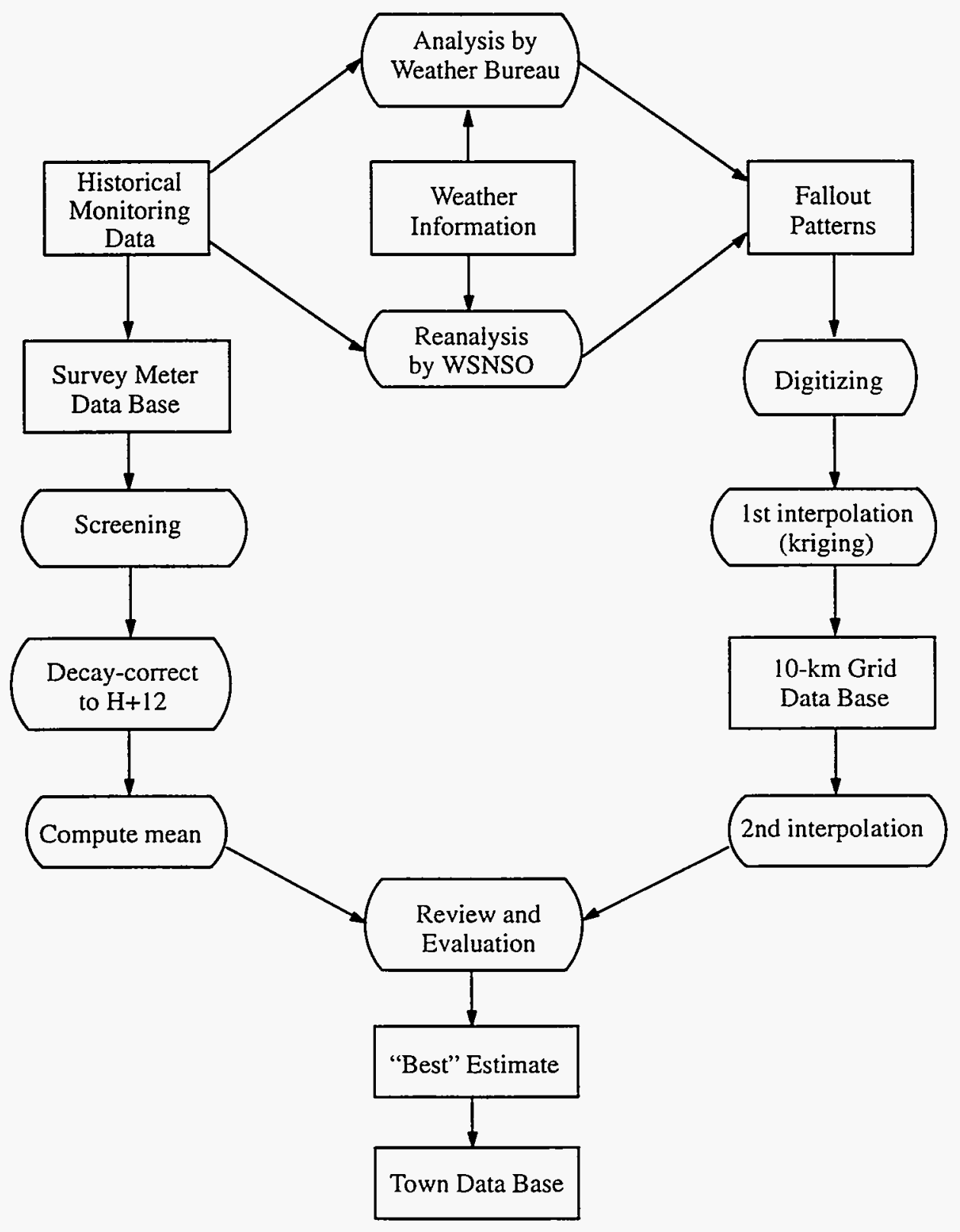

Figure 4. Generalized flow diagram of the estimation process. 
The first step in producing estimates from the fallout patterns was to digitize the isopleths, that is, convert the lines on the maps into a numerical form that could be used by computer programs. Next, an interpolation method called "kriging" was used to estimate both arrival time and exposure rate at the nodes of a square grid of points $10 \mathrm{~km}$ apart that covered the area of the isopleths on the fallout pattern. The collection of estimates at the grid nodes for all 77 events is called the $10-\mathrm{km}$ Grid Data Base. The values of $X_{E}$ and $X_{T}$ for any location were then interpolated from the estimates at the grid nodes surrounding the location, using a distance-weighted formula that gives greater importance to the values at the nodes closer to the location.

Because the survey meter data provide relatively little information about the time of fallout arrival, the $X_{T}$ values derived from the fallout patterns are the primary source of arrival time estimates in the Town Data Base. On the other hand, the survey meter data are the primary source of exposure rate estimates because they do not smooth the data as the fallout patterns do and because they provide a better representation of the dispersion.

Estimates for a given location were calculated from the survey meter data by first retrieving from the Survey Meter Data Base all measurements made within $2.5 \mathrm{~km}$ of the location. From these measurements were selected all those that were measurements of $\gamma$ radiation taken $1 \mathrm{~m}$ above the ground, taken at or after the estimated arrival time $\left(X_{T}\right)$, and considered usable (non-suspect) for dose calculations. A background value was then subtracted from each selected measurement, and the net value was decay-corrected to $\mathrm{H}+12$. An arithmetic mean and standard deviation were calculated and these were transformed, if possible, to a geometric mean and standard deviation.

Once estimates were created from both the fallout patterns and the survey meter data, an extensive and thorough review was performed. The objective of the review was to confirm the estimates with other available information, to resolve any apparent anomalies, and to select the locations with discernible amounts of fallout for inclusion in the Town Data Base.

\subsection{THE TOWN DATA BASE}

The Town Data Base contains the location and event information and parameter estimates for 1,910 combinations of location and nuclear event. It has at least one record for each of 74 events and each of 353 locations. Appendix B describes the format of the data base, while Appendix C contains a listing of the records.

The first version of the Town Data Base was created in 1985. Over the next few years, the data base was revised several times to incorporate different methods of calculation, improved analytical and review processes, and updated versions of the input data bases. The methods described in this report were used to create the fourth and final version. Version 4.0 of the Town Data Base was distributed to ORERP scientists in October 1989; it was followed by version 4.1 in February 1990. A final check of the data base was made in 1992 and 1993 to ensure that all decisions were properly documented and that the estimates reflected the final decisions. The last revision of the data base, version 4.2, includes a few minor changes resulting from this final check. These changes are noted on the listing in Appendix C. 


\section{ESTIMATES FROM FALLOUT PATTERNS}

\subsection{FALLOUT PATTERNS}

One important source of data for the estimates was the set of fallout patterns produced in the 1950s and 1960s to help assess the spread and the levels of fallout produced by each nuclear event. These patterns were hand-drawn isopleths developed from survey meter readings and information on the prevailing weather systems at the time of the event. Many of them were published in Nagler and Telegadas (1956), Goeke (1958), and Telegadas and Nagler (1960). Patterns from events conducted after 1958 have apparently not been published, but they can be obtained from the Coordination and Information Center at the address given at the end of the References.

The exposure rate patterns for most events were produced from survey meter readings that were normalized to $\mathrm{H}+12$. For some events where fallout did not extend far off the NTS, the exposure rates were normalized to $\mathrm{H}+1$. When the $\mathrm{H}+1$ isopleths were digitized, the exposure rate values were converted to $\mathrm{H}+12$ using the $t^{-1.2}$ model:

$$
E R(12)=E R(t) \cdot(12 / t)^{-1.2}
$$

where $t$ is the number of hours from detonation for the value on the map. For example, if the exposure rate is $0.4 \mathrm{mR} / \mathrm{hr}$ on an $\mathrm{H}+1$-hour map, the value at $\mathrm{H}+12$ is

$$
E R(12)=0.4(12 / 1)^{-1.2}=0.4(0.05)=0.02 \mathrm{mR} / \mathrm{hr} .
$$

Most fallout patterns also included isopleths of the time of fallout arrival. The exact meaning of this quantity was a subject of much discussion in the early stages of the ORERP. In general terms, the arrival time is the time, in hours after detonation, that the fallout cloud from a given nuclear event arrived at a given location. Several more precise or quantitative definitions can be given, and at least four possibilities were considered (Miller, 1982):

- the time when a substantial part of the fallout reached the ground (used by the Weather Bureau in creating original fallout patterns);

- the time when a time-of-arrival detector recorded a value $2 \mathrm{mR} / \mathrm{hr}$ above background (such detectors were used during Operation Plumbbob in 1957);

- the time of the maximum rate of fallout (used by the WSNSO in their reanalysis of fallout patterns); and

- the time that equalizes the two shaded areas $\mathrm{A}$ and $\mathrm{B}$ in Figure 2 so the area under the approximate curve is the same as the area under the true curve (Kennedy, 1981).

Values of time of fallout arrival derived using these definitions typically differ by 15 to 30 minutes down the center of a pattern and perhaps up to an hour near the outer edges. Such differences are considered small relative to the precision with which arrival time can be estimated. For the purposes of this report, the time of fallout arrival is defined as the quantity represented by the arrival time isopleths on the fallout patterns.

Arrival times were determined by examining profiles of exposure rate versus time where data were available. Where there were no profiles, winds-aloft data were analyzed to estimate the time 
that fallout particles would have arrived at a location. These arrival times were plotted on the fallout pattern map and isopleths were drawn to them.

Seventy-five fallout maps were located, giving patterns for 77 events which may have produced discernible fallout off-site (U. S. Department of Energy, 1989). (One map has patterns for both the SOCORRO and WRANGELL events, while another has patterns for SANFORD and DE BACA.) The names of all 77 events are included in Table 4 in Section 6. Ground monitoring data were taken before, during, and after many other nuclear events for which fallout patterns were not produced because the levels of exposure rate off the NTS were low.

In the early 1980s, the fallout patterns for 11 events (ANNIE, BADGER, BEE, BOLTZMANN, EASY, HARRY, NANCY, SIMON, SMALL BOY, SMOKY, and ZUCCHINI) were reanalyzed by the WSNSO using ground monitoring data, information about prevailing weather systems, and aerial survey data (Quinn, 1986a, 1986b, 1987; Quinn et al., 1981, 1982, 1984, 1986; Steadman, 1988; Steadman et al., 1983a, 1983b, 1984a, 1984b). The methods used were similar to those for the original analyses, though the survey meter data were more carefully assessed and questionable values were adjusted or discarded before the calculations were performed. For these 11 events, the revised patterns were used instead of the original patterns to produce estimates. The WSNSO also reviewed available information to provide isopleths of the time of fallout arrival for a few events which did not have arrival time isopleths on the original fallout pattern.

\subsection{DIGITIZING AND INTERPOLATING}

Estimates were obtained from each fallout pattern through a three-step process. First, the isopleths were digitized to convert them into a numerical form. Next, the digitized data were used along with an interpolation program to estimate values on a $10-\mathrm{km}$ square grid of points covering the fallout pattern. Finally, the grid estimates were used to interpolate values at the locations of interest within the grid. The first two steps are described in this section, and the third step is described in Section 3.3.

Digitizing was the method chosen to computerize the information from the hand-drawn exposure rate and arrival time isopleths. The procedure involved placing the fallout pattern on a digitizing pad and tracing each isopleth with a special pen that recorded the $\mathrm{X}$ and $\mathrm{Y}$ coordinates of the pen's location and the isopleth level whenever a button was pressed. The spacing of digitized points along the isopleths varied, with straight segments having fewer points than sharply curved segments. When the procedure was complete, each isopleth was represented in a computer file by a set of records, each containing the isopleth level and the coordinates of a point on that isopleth. Two such files were created for each pattern, one with the exposure rate isopleths, the other with the arrival time isopleths. After the digitizing was completed, every digitized pattern was plotted and compared with the original pattern to check for errors and to verify that the digitized version adequately represented the isopleths.

Early attempts to interpolate from the digitized arrival time data gave poor results in regions near the lowest and highest isopleths. To help provide more realistic interpolated values in these regions, two extra isopleths were drawn and digitized along with the original isopleths. One was drawn about midway between the end of the exposure rate isopleths nearest to the point of detonation and the first arrival time isopleth. This isopleth was given a value equal to half the value of the first arrival time isopleth. The second was drawn at the other end of the pattern, beyond the last arrival time isopleth at about the spacing of the previous two. This new isopleth was given a value equal 
to one more than the largest arrival time isopleth level. Figure 3 shows the two additional isopleths drawn for event EASY.

Also, the interpolation program estimates a value at each grid node from the nearest eight data points. To ensure having enough data in the area of each node, additional points were added between digitized points on each exposure rate isopleth. For isopleths greater than or equal to $40 \mathrm{mR} / \mathrm{hr}$, the maximum distance between digitized points was no more than $1 \mathrm{~km}$ and for isopleths less than $40 \mathrm{mR} / \mathrm{hr}$, the maximum distance was no more than $2 \mathrm{~km}$. Addition of points to the digitized isopleths of arrival time was not necessary because the isopleths were relatively straight.

All 75 historical fallout patterns were digitized in 1980 and 1981. Revised patterns were digitized as they were produced by the WSNSO.

The second step in obtaining estimates from the fallout patterns was using the digitized data to create a grid of equally spaced points, each having an estimate of exposure rate and time of fallout arrival. Some consideration was given at first to using a grid of points $5 \mathrm{~km}$ apart. Eventually, it was decided that interpolating to such a fine grid with such sparse data would be attempting to create more precision than existed in the fallout patterns. Instead, a $10-\mathrm{km}$ by $10-\mathrm{km}$ grid was selected. In examining the distance between isopleth lines, especially the ones for exposure rate, it was found that gradients were usually steep only in the region near the NTS, where there were very few locations of interest. The remainder of a pattern contained gradients that were less steep, so that estimates on a $10-\mathrm{km}$ grid covering the pattern could reflect the gradients well.

The grid origin was the same for all events: $37^{\circ}$ north latitude and $116^{\circ}$ west longitude, a location near Yucca Lake on the NTS. Figure 5 shows an example of the 10-km grid overlying the pattern of event EASY.

Two methods were used to interpolate from the digitized fallout patterns to the $10-\mathrm{km}$ grid. The modified Shepard's method (Foley, 1981) was initially preferred because it was easier to use. However, it did not give acceptable estimates in regions where values were changing rapidly. Early in 1982 , kriging was adopted as the method for creating the $10-\mathrm{km}$ grid estimates.

Kriging is an estimation method first developed by statisticians in the mining industry. It differs from classical spatial estimation methods in that it uses the correlation between values measured at a set of locations to estimate the value at an unmeasured location. In the present context, the measured locations are the digitized points on the isopleths, while the unmeasured locations are the nodes of the $10-\mathrm{km}$ grid. Kriging has some optimal properties from a statistical standpoint, and it provides an estimate of the uncertainty in the interpolated values (the kriging error). A discussion of kriging is beyond the scope of this report. Journel and Huijbregts (1978), David (1977), and Delfiner and Delhomme (1975) provide good explanations of the technique.

Kriging was carried out by first running each file of digitized data for an event through a computer program called GAMMA (Chiles, 1975) to compute the sample variogram, a function that expresses the spatial correlation of the data in terms of the distance between the observed values. The output from GAMMA was used to estimate the parameters defining the kriging model. The corresponding file of digitized points and these parameters were then input to the computer program BLUEPACK (Delfiner et al., 1976) to produce a set of kriged estimates at each node of the 10-km grid. BLUEPACK produces estimates on a rectangular grid of points specified by the user rather than on a grid in the shape of the fallout pattern. To provide estimates for exposure rate and arrival time 


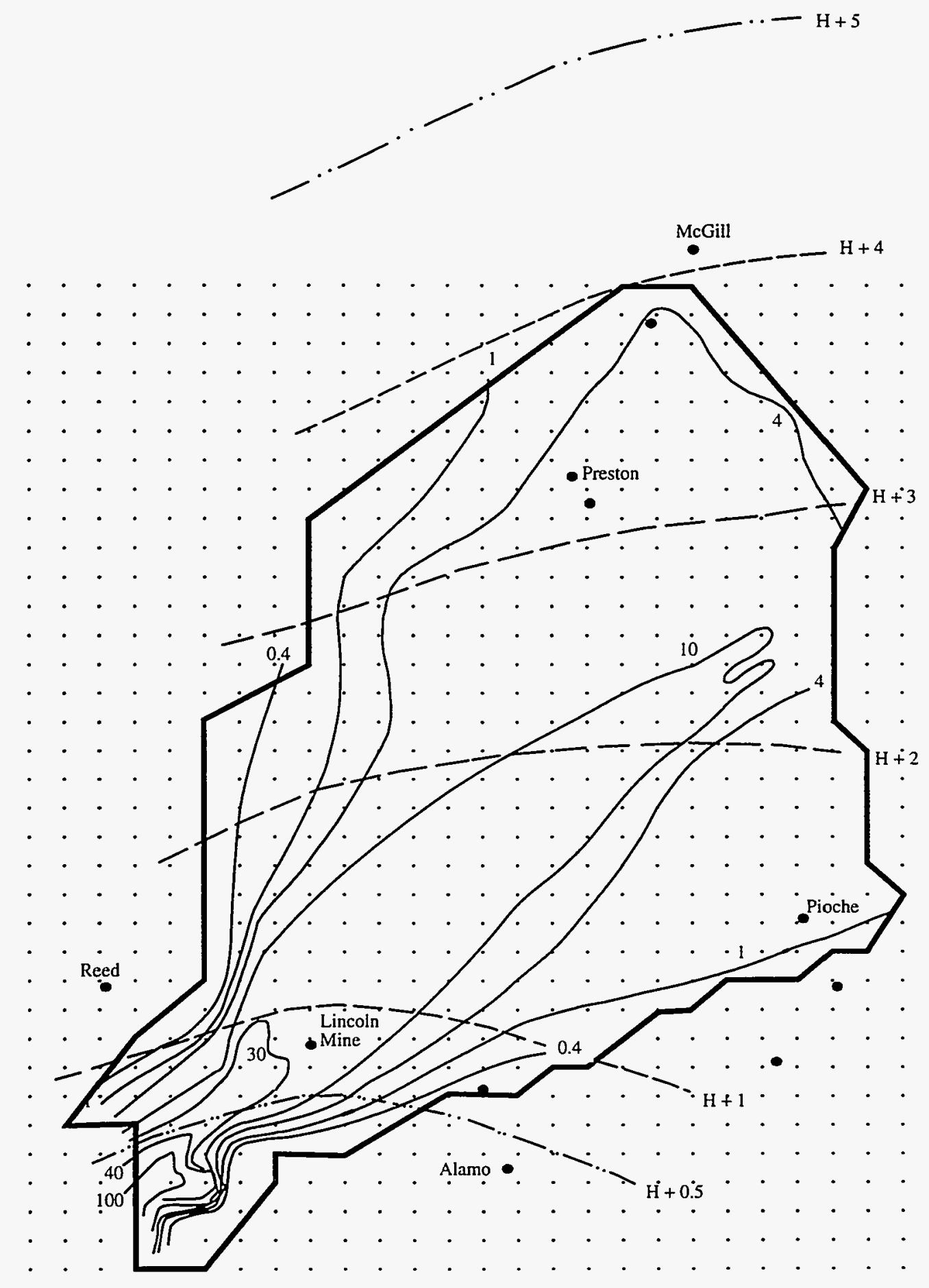

Figure 5. Points of the 10-km grid superimposed on the fallout pattern from event EASY. The solid black line encloses the grid points considered usable for calculating estimates. 
over the same area, the bounds of the rectangle for a given event were chosen to give the closest fit to the exposure rate isopleths. The grid overlay in Figure 5 is an example of the rectangle fit to a pattern.

Comparison of the grid estimates to the original isopleths showed that kriging performed well in interpolating to the grid nodes in the areas bounded by the actual data. Because the kriging estimates outside of these areas did not al ways reflect the expected decrease of exposure rate with distance from the NTS, a flagging procedure was developed to differentiate grid points. The grid nodes that most closely enclosed the exposure rate isopleths and all the nodes within that enclosure were flagged as nodes that were usable for estimation. Thus the set of grid estimates used in further calculations for an event was determined by the exposure rate isopleths. The same nodes were flagged for the arrival time estimates even though the isopleths for arrival time generally extended beyond those for exposure rate. In a few cases, estimates of exposure rate at nodes on the boundaries or in the center of the pattern did not change consistently with the gradient or had large kriging errors. These nodes were not flagged and were not used in further calculations for that event.

Figure 5 shows the grid points for event EASY that were flagged as usable for subsequent estimation. Figure 6 is a subset of the grid of exposure rate values showing an example of the interpolated fit.

The exposure rate and arrival time estimates for all nodes (flagged and unflagged) in the rectangle of the 10-km grid surrounding the isopleths for each event were combined to form the 10-km Grid Data Base. These rectangles cover the most current sets of isopleths for all 77 events with fallout patterns. Each record in the data base contains the values at a node for a given event. The fields associated with each node include the event name, the distance of the node from the grid origin in the north-south and east-west directions, the kriging estimates and kriging errors of exposure rate and arrival time, and the usability flag.

The grid estimates for event BANEBERRY required special treatment because the isopleths on the fallout pattern were in units of net infinite external gamma exposure $(\mathrm{mR})$ rather than $\mathrm{mR} / \mathrm{hr}$ as on the other maps. The isopleths were digitized and estimates were produced at the grid points using the $\mathrm{mR}$ units. Each grid estimate was then transformed to an estimate of $\mathrm{H}+12$ exposure rate with the equations

$$
\begin{aligned}
E & =\int_{T}^{\infty} E R(1) t^{-1.2} d t \\
E R(1) & =(E / 5) T^{0.2} \\
E R(12) & =E R(1)(12)^{-1.2} .
\end{aligned}
$$

Here $E$ is the interpolated exposure and $T$ is the interpolated arrival time at the grid point. The first equation expresses the exposure as a function of the exposure rate at $\mathrm{H}+1$ and time; the second follows from the first by integrating and solving for $E R(1)$; the third decay-corrects the exposure rate to $\mathrm{H}+12$ using equation (1). 


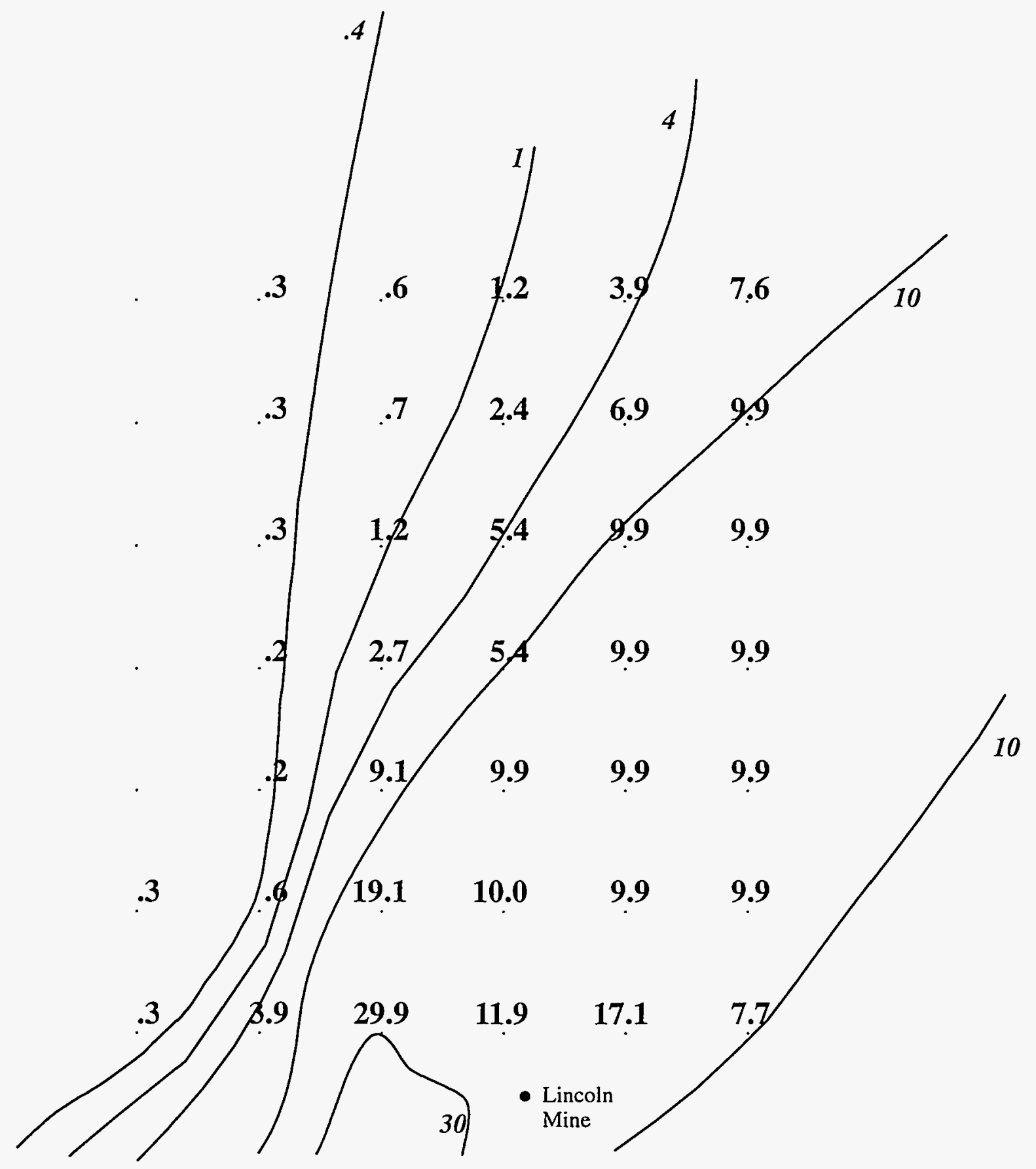

Figure 6. Part of the EASY fallout pattern showing the interpolated exposure rates $(\mathrm{mR} / \mathrm{hr})$ at the $10-\mathrm{km}$ grid points. 


\subsection{CALCULATING THE ESTIMATES}

The third part of the process was to calculate estimates for populated locations using the 10-km Grid Data Base.

\subsubsection{Estimates of the Mean}

A second interpolation scheme was developed to produce estimates of $X_{E}$ and $X_{T}$ for any location within one of the squares of the $10-\mathrm{km}$ grid. Because of the flagging process, a location could fall into a grid square with anywhere from 0 to 4 usable grid points. An estimate was made only if there were two or more usable grid points surrounding the location.

Consider first the estimate of the geometric mean of the exposure rate estimates at location $L$, $X_{E}(L)$. Let $E R_{i}$ be the estimated exposure rate at the $i$ th corner of the square surrounding $L$, and let $D_{i}$ be the Euclidean distance from $L$ to the $i$ th corner. The estimate of $X_{E}(L)$ is then calculated as

$$
X_{E}(L)=\exp \left[\sum_{i=1}^{n} K_{i} \ln \left(E R_{i}\right)\right],
$$

where $K_{i}$ is the distance-weight associated with $E R_{i}$, that is,

$$
K_{i}=\left(1 / D_{i}\right) / \sum_{j=1}^{n}\left(1 / D_{j}\right)
$$

and $n=2,3$, or 4 depending on the number of usable grid points. $K_{i}$ is inversely related to the distance of the location from the $i$ th corner.

The estimate of the (arithmetic) mean arrival time, $X_{T}(L)$, is calculated similarly, using normal values instead of logarithms:

$$
X_{T}(L)=\sum_{i=1}^{n} K_{i} T_{i}
$$

where $T_{i}$ is the estimated time of fallout arrival at the $i$ th corner.

As an example, consider the estimation of exposure rate for Leeds, Utah, from event HARRY. The data for the four surrounding grid points from the $10-\mathrm{km}$ Grid Data Base (distance east and north of the grid origin and interpolated exposure rate), as well as the calculated distance $D$ from Leeds (232 km east and $25.1 \mathrm{~km}$ north of the origin) and the weight $K$, are listed below:

$\begin{array}{cccccc}\text { Point on Grid } & \begin{array}{c}\text { east } \\ (\underline{\mathrm{km})}\end{array} & \begin{array}{c}\text { north } \\ (\underline{\mathrm{km}})\end{array} & \begin{array}{c}E R \\ (\mathrm{mR} / \mathrm{hr})\end{array} & \begin{array}{c}D \\ (\mathrm{~km})\end{array} & \underline{K} \\ \begin{array}{c}\text { upper left } \\ \text { upper right }\end{array} & 230 & 30 & 69 & 5.3 & .323 \\ \text { lower left } & 240 & 30 & 38 & 9.4 & .184 \\ \text { lower right } & 230 & 20 & 39 & 5.5 & .311 \\ & 240 & 20 & 49 & 9.5 & .182\end{array}$


Using $n=4$ in equation (2),

$$
\begin{aligned}
X_{E}(\text { Event HARRY at Leeds }) & =\exp [0.323 \ln (69)+0.184 \ln (38)+0.311 \ln (39)+0.182 \ln (49)] \\
& =\exp (3.89)=49 \mathrm{mR} / \mathrm{hr} .
\end{aligned}
$$

The above equations were used if the exposure rate values at all four corners of the square surrounding a location were flagged usable, as in Figure 7(a). Four points were not always available for an estimate, especially for locations near the borders of the exposure rate isopleths. If only three of the four points were flagged as usable, as in Figure 7(b), the weights $K_{i}$ were based only on the distances from those three corners. When three or four values were available, an estimate could be made for a location anywhere within the square. When only two of the four corners were flagged as usable, as in Figure 7(c), an estimate of $X_{E}$ was calculated only if the two usable corners were adjacent and if the location fell exactly on the line connecting these corners.

For any of the cases in Figure 7, $X_{E}$ was calculated from equations (2) and (3) and $X_{T}$ was calculated from equations (3) and (4) by changing the value of $n$ appropriately. These are the only situations for which $X_{E}$ was calculated. No estimate was calculated if fewer than two of the grid points were usable.

Sometimes $X_{E}$ could be estimated from the survey meter data (as described in Section 4) for a location outside the flagged area. A value of $X_{T}$ for those locations was estimated by extending the curvature of the existing arrival time isopleths manually and interpolating by eye. These subjective estimates were made to either the nearest half hour or hour depending on the density of the isopleths and the distance of the location from the isopleths.

The SMALL BOY event posed a special situation because there were only three isopleths for arrival time $(5,10$, and 15 hours), but the isopleths for exposure rate extended well past the 15-hour isopleth. Kriging creates grid estimates using available data and thus the $X_{T}$ values at grid points where no isopleths existed had a maximum value of $15 \mathrm{hr}$ and a minimum value of $5 \mathrm{hr}$. To develop $X_{T}$ values more consistent with the probable passage of the cloud, approximate isopleths were drawn for one-hour increments between the $\mathrm{H}+5$ and $\mathrm{H}+15$ isopleths. The approximate one-hour distance between isopleths was then used to create isopleths beyond 15 hours. The $X_{T}$ value for a location outside the published isopleths was then estimated visually from these additional isopleths.

Sometimes a value of $X_{E}$ could be estimated from survey meter data for an event for which there was no fallout pattern and thus no isopleths from which to estimate $X_{T}$. In such cases, an attempt was made to determine a value of $X_{T}$ from the survey meter data (possible if a series of measurements was made at the same location) or from contemporary reports that summarized those data. 


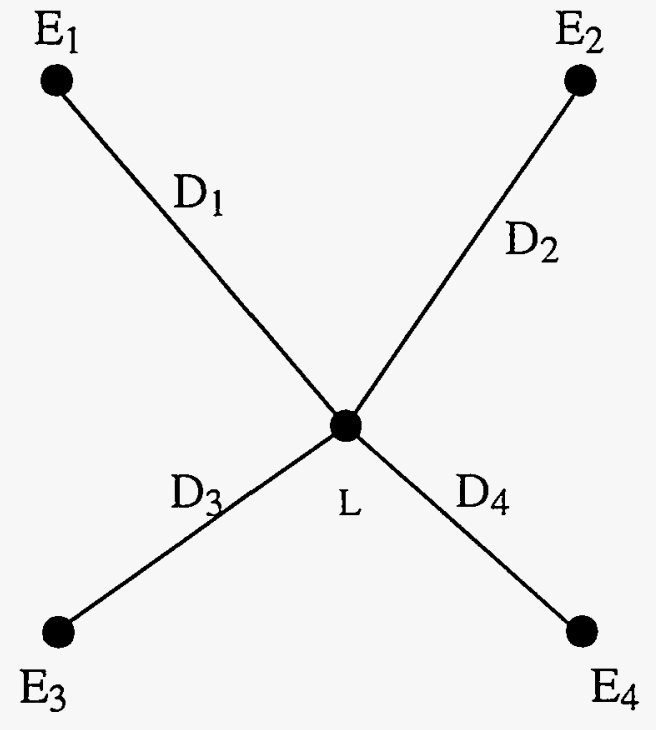

(a) 4 usable values

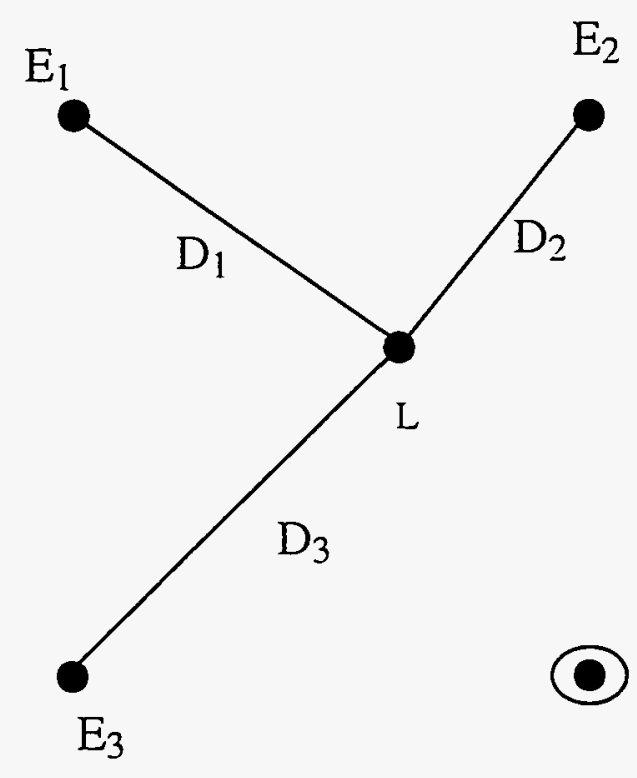

(b) 3 usable values
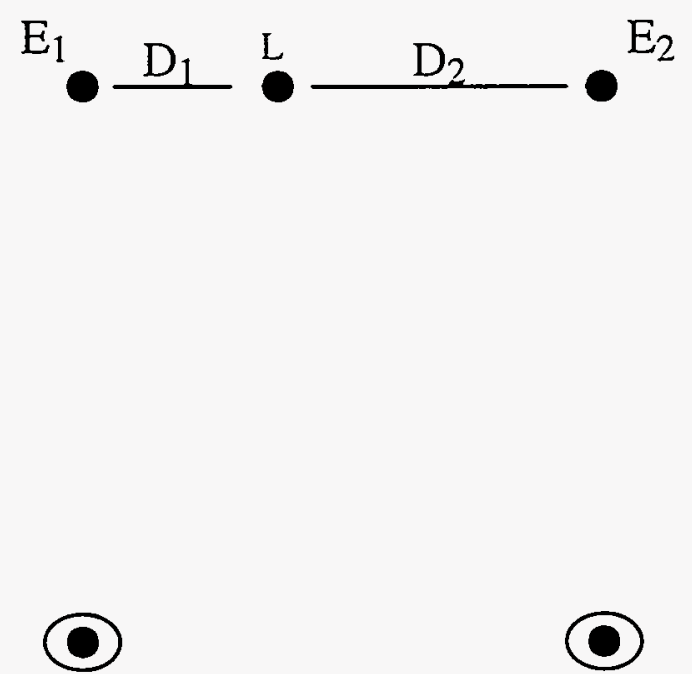

(c) 2 usable values

Figure 7. Situations where estimates can be calculated from the $10-\mathrm{km}$ grid. $L$ is the location for which estimates are to be made; the $E_{i}$ are values interpolated from a fallout pattern at the grid nodes; and $D_{i}$ is the distance from node $i$ to $L$. Values at circled grid nodes are not used in the calculation. 


\subsubsection{Estimates of Dispersion}

The kriging error associated with the estimate of exposure rate or arrival time at each node of the 10-km grid is a measure of precision of the estimate rather than a measure of dispersion for the statistical distribution of the estimate. Although values of $S_{E}$ and $S_{T}$ were interpolated from the kriging error, these values were not used as dispersion estimates. The estimates of both $X_{E}$ and $S_{E}$ produced directly from the survey meter measurements were deemed to better reflect the exposure rate distribution than the estimates produced from the fallout patterns. Thus, the $S_{E}$ for a location where $X_{E}$ could be estimated only from the fallout pattern for an event was based, if possible, on survey meter data from nearby locations.

The procedure was carried out after the data in the Survey Meter Data Base had been used to estimate $X_{E}$ and $S_{E}$ for as many locations as possible, as described in the next section. For a given location $L$ for which $X_{E}$ could not be estimated from the survey meter data but could be estimated from the fallout pattern, all locations within $12 \mathrm{~km}$ of $L$ that did have an $X_{E}$ value based on the survey meter data were selected. From the $S_{E}$ values for those locations, a pooled dispersion estimate $S_{E}(L)$ was calculated as

$$
S_{E}(L)=\exp \left[\sqrt{\sum_{i=1}^{m} \frac{\ln ^{2} S_{i}}{m}}\right],
$$

where $S_{i}$ is the $i$ th $S_{E}$ value and $m$ is the number of usable $S_{E}$ values. These calculations did not include any $S_{E}$ based on only one measurement. A default $S_{E}$ value of 1.4 was assigned to locations for which either no $S_{E}$ based on survey meter data was available or the available $S_{E}$ values were all based on only one measurement. This default value was the median value of all the $S_{E}$ values based on more than one measurement from the Survey Meter Data Base and used in the Town Data Base (the range of these values was 1.0 to 4.3). The default $S_{E}$ value represents a combination of variability from different instruments and variability from other sources of error present in the measurements taken at the locations.

To develop an estimate of dispersion for the distribution of time of fallout arrival, information was obtained from the scientists at the WSNSO about the variability found in their reanalysis of the fallout patterns for 11 events. For situations with simple meteorology, where the winds did not change much with time or distance, differences of 15 to 30 minutes were found between meteorologically derived fallout times and those obtained from profiles of exposure rate versus time. For situations with more complex meteorologic conditions, the differences were about an hour or more. In either case, the differences increased as the distance from the point of detonation increased. Because this is equivalent to an increase in the dispersion as the time from detonation increases, the dispersion estimate $S_{T}$ was made a function of time.

In most cases when $X_{T}$ was estimated from the $10-\mathrm{km}$ grid (that is, the location was within the flagged area of the fallout pattern), or when the location was just outside the isopleths where $X_{T}$ was easily determined, $S_{T}$ was set equal to $0.1 X_{T}$. For a location outside an event's isopleths where $X_{T}$ was estimated by manually extending the isopleths, $S_{T}$ was set equal to $0.15 X_{T}$. These formulas are somewhat generalized and subjective, but they provide a feasible alternative to the extensive analysis of data that would be required to obtain more accurate dispersion estimates for each event. Most time of arrival values are in a range of from 3 to 10 hours, so the estimated dispersions are of the same order of magnitude as the differences typically found in the WSNSO reanalyses (V. E. Quinn, Weather Service Nuclear Support Office, personal communication, 1987). 


\section{ESTIMATES FROM SURVEY METER DATA}

\subsection{THE SURVEY METER DATA}

The other major source of data for estimating exposure rate was the measurements of external gamma exposure rate taken by monitors in the field and later retrieved and entered into the Survey Meter Data Base. During fallout monitoring, collecting data was less important than ensuring public safety, and the intense scrutiny that the data have undergone in the last decade was not anticipated when the monitors were given instructions for taking measurements. More than 30 years have passed since much of the information was collected, making it difficult to detect or correct errors without some subjective interpretation. Even though the original data are not without errors or uncertainties, they are the best field measurement data available.

Initially, attempts were made to use the survey meter data with interpolants such as bicubic splines and kriging to create estimates on the $10-\mathrm{km}$ grid. It was felt that the estimates would be more rigorous and defensible if they were generated directly from actual measurements. However, because the data were taken primarily along roads and in towns, there were large areas in which no measurements were made (see Figure 8). As a result, the estimates produced by the interpolants were often inconsistent with the original data. The fallout patterns proved to be a better source of data for the interpolant estimation because data existed throughout the area of interest and because weather conditions were taken into account when the patterns were produced. On the other hand, the survey meter measurements probably provide the most accurate picture of the radiological condition in a given populated area at a given time. Therefore, $X_{E}$ and $S_{E}$ estimates created from survey meter measurements are usually given more credence than those derived from a fallout pattern.

\subsection{SELECTING THE MEASUREMENTS}

To estimate $X_{E}$ and $S_{E}$, the Survey Meter Data Base was first searched for all measurements within $2.5 \mathrm{~km}$ of the location of interest. Those measurements were screened to eliminate the ones that were not suitable for use in the estimation. The initial screening retained only measurements that were readings of $\gamma$ radiation taken $1 \mathrm{~m}$ above the ground, outside any vehicle or building, and at or after the estimated $X_{T}$ for the location. (Most estimates of $X_{T}$ were interpolated from the 10-km grid, but some were obtained by manually extending the isopleths or from reports or survey meter data (Section 3.3.1). In some cases, an $X_{T}$ value based on reports or survey meter data was used in place of one derived from the fallout patterns to give a more consistent estimate of $X_{E}$. See also the description of the estimation and review process in Section 5.)

Other measurements were rejected because they were considered unusable for dose calculations. The data in the Survey Meter Data Base were examined carefully when the data base was created, and some measurements were noted at that time as being suspect. The WSNSO scientists also reviewed the data for 11 events to determine which were the most reliable for reanalyzing the fallout patterns. Those data were flagged in the Survey Meter Data Base to be used for the individual exposure rate estimates as well. The WSNSO was later asked to review the remaining data for those events and assess whether each measurement was reliable enough for use in estimate calculations. Some data were rejected for use as a result of that assessment.

Another problem encountered with some of the survey meter data was due to the difficulty inherent in measuring low levels of radiation. Because of the random nature of radioactive decay, 


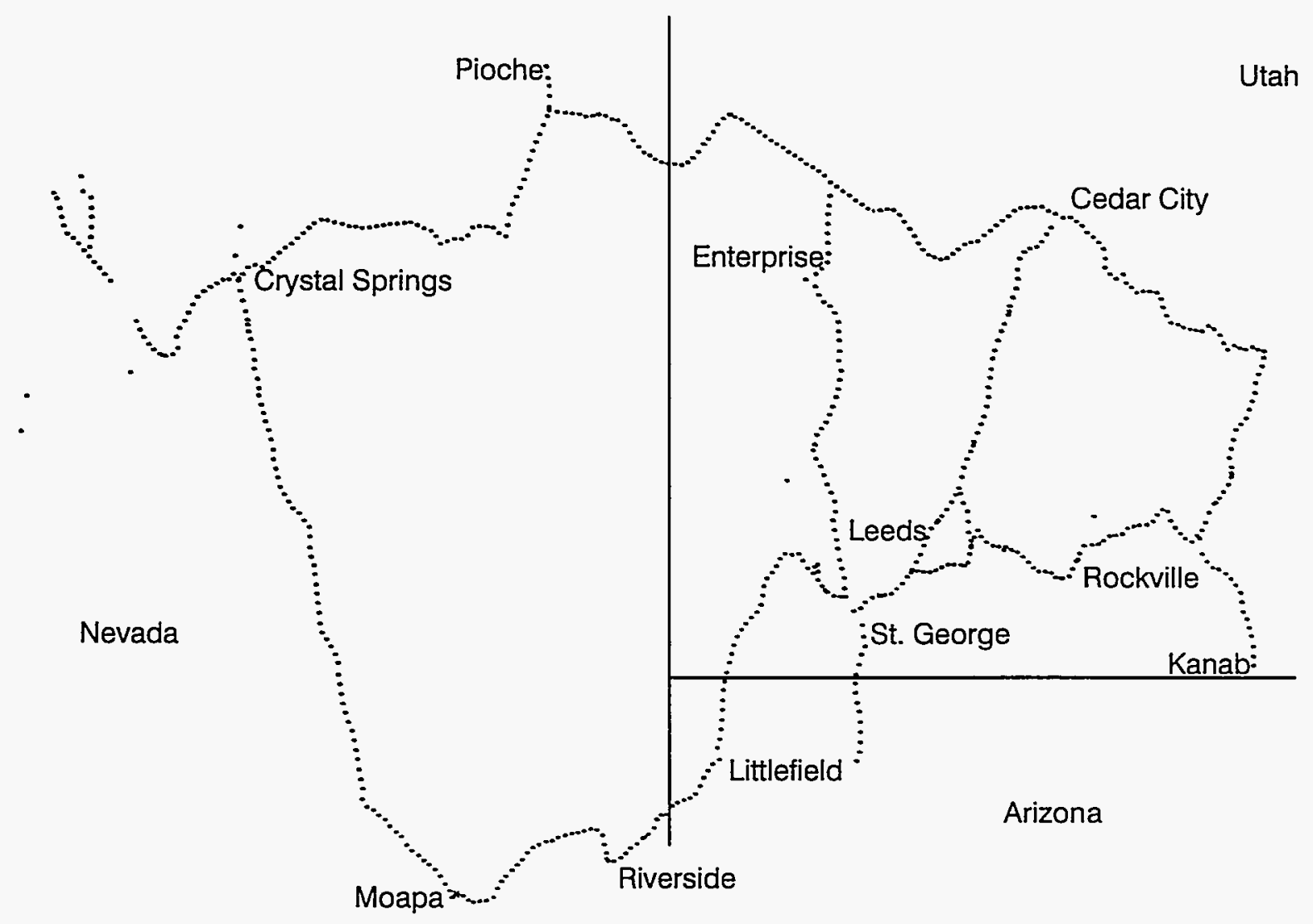

Figure 8. Locations at which survey meter data were collected for event HARRY (see also Quinn et al., 1981).

the number of gamma rays emitted will vary from one time interval to another. If the average number is small, the amount of variation will be relatively large, causing a relatively large uncertainty in the measured value. In general, the radiation level has to be at least twice as high as the natural background level to be detectable with the kinds of instruments used by the fallout monitors. Thus it was not always clear whether low values in the Survey Meter Data Base represented low levels of fallout or just variations in the measurement of the background level.

This problem was compounded if the low measurement had been made several days after the event. Although in theory the fallout will eventually decay to an arbitrarily low level, in practice the radiation level will never be less than the natural background. If a reading that is mostly background is decay-corrected back several days to $\mathrm{H}+12$, an inflated value will be obtained. For example, if an exposure rate $0.02 \mathrm{mR} / \mathrm{hr}$ above background was recorded at $\mathrm{H}+60$, the value normalized to $\mathrm{H}+12$ using equation (1) would be: 


$$
E R(12)=0.02(12 / 60)^{-1.2}=0.02(6.90)=0.14 \mathrm{mR} / \mathrm{hr}
$$

If the measurement was taken at $\mathrm{H}+100$, the $\mathrm{H}+12$ normalized value would be

$$
E R(12)=0.02(12 / 100)^{-1.2}=0.02(12.730)=0.25 \mathrm{mR} / \mathrm{hr}
$$

Such normalized values are not very reliable because the $0.02 \mathrm{mR} / \mathrm{hr}$ may represent just an unusually high reading of the background level rather than actual fallout. In addition, if such values were much greater than other normalized measurements for that location taken at earlier times (for example, if all other $\mathrm{H}+12$ values were less than $0.04 \mathrm{mR} / \mathrm{hr}$ ), both the $X_{E}$ and $S_{E}$ estimates would be higher than expected. If the estimates did not agree with other sources of information (reports, fallout maps, estimates for nearby locations), the data were reviewed and measurements may have been excluded from further use. Measurements were excluded for this reason only if they were taken more than 60 hours past detonation and had low net exposure rate values, on the order of 3 times background or less.

The problems arising from measured values near the background level were identified during the first attempts to create the Town Data Base. After much discussion among the ORERP's task group leaders and scientific advisors failed to reach a resolution, the project leaders mandated an interim solution in ORERP Project Directive No. 10. Although most of the specified procedures were later made obsolete by changes in the Survey Meter Data Base and in estimation methods, the directive is reproduced in Appendix D for the sake of completeness.

\subsection{CALCULATING THE ESTIMATES}

Once a set of usable measurements had been selected, a net exposure rate,

$$
N=\text { gross value }- \text { background value, }
$$

was calculated for each one. The monitors did not always record a background value for a measurement. If no background value was given in the Survey Meter Data Base, a default background value for an event was used. The normal background rate for each event processed was $0.02 \mathrm{mR} / \mathrm{hr}$ except for event HARRY. The reanalysis of the HARRY fallout pattern event by the WSNSO suggested that its normal background level was $0.05 \mathrm{mR} / \mathrm{hr}$ (Quinn et al., 1981).

In the WSNSO reanalyses of the 11 events, some survey meter measurements were found to be inconsistent with other supporting information. These measurements were annotated in the WSNSO reports with either correction factors $(0.5$ to 100$)$ or an indication of their reliability (for example, Steadman et al., 1983b). These same adjustments were applied to the net values before further calculations were made.

The next step was to decay-correct each net value to its value at $\mathrm{H}+12$ using a sum of 11 time-dependent exponential functions. The decay factor $d f$ is

$$
d f=\sum_{i=1}^{11} a_{i} \exp \left(-b_{i} t\right)
$$

where $t$ is the time (hr) from event occurrence until the measurement was taken and $a_{i}$ and $b_{i}$ are coefficients defining the exponential functions. Values of these coefficients for the various events 
were provided by R.W. Henderson of Los Alamos National Laboratory. The decay-corrected value was then calculated as

$$
E R(12)=N / d f .
$$

The last step was to calculate the geometric mean $X_{E}$ and standard deviation $S_{E}$ from the net exposure rate values. The usual method would involve taking the logarithm of each value and computing the statistics of the logarithms. In many instances, however, the calculated net exposure rate measurement was equal to 0 , so this method could not be used. Several alternatives were evaluated, including discarding the zero values or adding a small amount to each measurement before taking logarithms. Finally, a calculation procedure was developed based on the method of moments (Freund, 1971).

The first step was to compute the arithmetic mean and variance of the untransformed data by the usual formulas:

$$
X_{H}=\sum_{i=1}^{m} E R_{i} / m
$$

and

$$
S_{H}^{2}=\sum_{i=1}^{m} \frac{\left(E R_{i}-X_{H}\right)^{2}}{m-1}
$$

where $E R_{i}$ is the $i$ th value of $E R(12)$ and $m$ is the number of usable $E R(12)$ values for the location. These sample moments were then equated to their theoretical values (Aitchison and Brown, 1957):

$$
\begin{gathered}
X_{H}=\exp \left(X_{l}+S_{l}^{2} / 2\right) \\
S_{H}^{2}=\exp \left(2 X_{l}+S_{l}^{2}\right)\left[\exp \left(S_{l}^{2}\right)-1\right] .
\end{gathered}
$$

Solving (10) for $X_{l}$ and $S_{l}^{2}$ leads to

$$
\begin{gathered}
S_{l}^{2}=\ln \left[\left(S_{H} / X_{H}\right)^{2}+1\right], \text { the variance of the log-transformed measurements, and } \\
X_{l}=\ln \left(X_{H}\right)-S_{l}^{2} / 2, \text { the mean of the log-transformed measurements. }
\end{gathered}
$$

Finally,

$$
\begin{gathered}
X_{E}(L)=\exp \left(X_{l}\right) \text {, the geometric mean, and } \\
S_{E}(L)=\exp \left(S_{l}\right) \text {, the geometric standard deviation. }
\end{gathered}
$$


As an example, consider the usable survey meter data for event HARRY from Leeds, Utah. The number of hours from the time of the event (5:05 a.m. on 5/19/53), the net exposure rate value, and the $\mathrm{H}+12$ exposure rate calculated from (7) are given below:

$\begin{array}{rrr}\underline{\text { Hours }} & \begin{array}{c}N \\ (\mathrm{mR} / \mathrm{hr})\end{array} & \begin{array}{c}E R(12) \\ (\mathrm{mR} / \mathrm{hr})\end{array} \\ 6.0 & 59.95 & 25.7 \\ 14.2 & 31.95 & 38.2 \\ 35.9 & 5.95 & 21.2 \\ 108.3 & 4.20 & 47.0\end{array}$

Using these data, equations (8) through (12) give values of:

$$
X_{H}=33.0 \quad S_{H}=11.8 \quad X_{l}=3.44 \quad S_{l}^{2}=0.121
$$

Then

$$
\left.X_{E} \text { (Event HARRY at Leeds }\right)=\exp \left(X_{l}\right)=31 \mathrm{mR} / \mathrm{hr}
$$

and

$$
S_{E}(\text { Event HARRY at Leeds })=\exp \left(S_{l}\right)=1.4
$$

If there was only one measurement taken for a location, the $X_{E}$ value was equal to the value of $H$ calculated in equation (7). No value of $S_{E}$ could be calculated, so the default dispersion value of 1.4 (Section 3.3.2) was assigned to $S_{E}$. 


\section{CREATING AND REVIEWING THE ESTIMATES}

\subsection{CREATING THE ESTIMATES}

The estimates described in Sections 3 and 4 were calculated with a series of computer programs

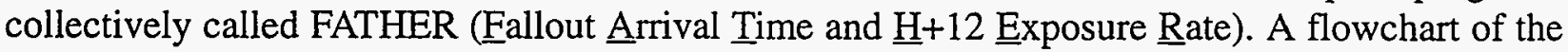
FATHER procedure is given in Figure 9. The description here is not a full documentation of the procedure, but it should provide enough of the general details to enable the following discussion of the estimate review process to be understood.

The first step of the procedure (program RETOFF) compared the latitude and longitude of a location with the bounds of the $10-\mathrm{km}$ grid rectangle for each event. If the location was within the grid rectangle, the program created estimates of the four parameters $X_{E}, S_{E}, X_{T}$, and $S_{T}$ for that location and event and wrote the estimates to a record called an "I" record. If the location was within the flagged area of usable 10-km grid values, the estimates of $X_{E}$ and $X_{T}$ were calculated as described in Section 3.3. The values of $S_{E}$ and $S_{T}$ were interpolated from the kriging errors; they were later replaced with better estimates of dispersion during the review. If the location was outside the flagged area (but still within the grid rectangle), all four estimates were given an unrealistically large value of 10,000 . A report was generated for each I record created to describe the grid values and distance weights used for the estimates.

If the location was outside the grid rectangle for all events in the 10-km Grid Data Base, a special record was created to make sure that the Survey Meter Data Base was checked for data from that location.

Program PRE checked each location against the Survey Meter Data Base to see if survey meter data existed for a given event. If so, an internal record was created for the next program. If an I record existed for the location and event, the $X_{T}$ value was included in the internal record. If not, the $X_{T}$ value was set to zero.

Program POS extracted the data for the location and event from the Survey Meter Data Base. Any data from within $2.5 \mathrm{~km}$ of the location were included without regard as to their usability for further calculations.

Program H12 looked at the resulting set of survey meter data and culled those that were less than $X_{T}$ or were otherwise unusable (Section 4.2). For each remaining measurement, the program calculated the net exposure rate, decay-corrected it using the 11-term exponential coefficients for the event, and calculated the geometric mean and standard deviation, if possible (Section 4.3). An " $R$ " record was generated for each location and event for which there is at least one measurement (usable or not) in the Survey Meter Data Base. The DETAILS report describes the records extracted, whether or not they were used, all calculations, and any comments from those records.

Finally, the REPORT program sorted the I and R records so all records for a given location and event were contiguous in the output file EXPOS. The complete set of estimates in the EXPOS file was then subjected to the review process. 


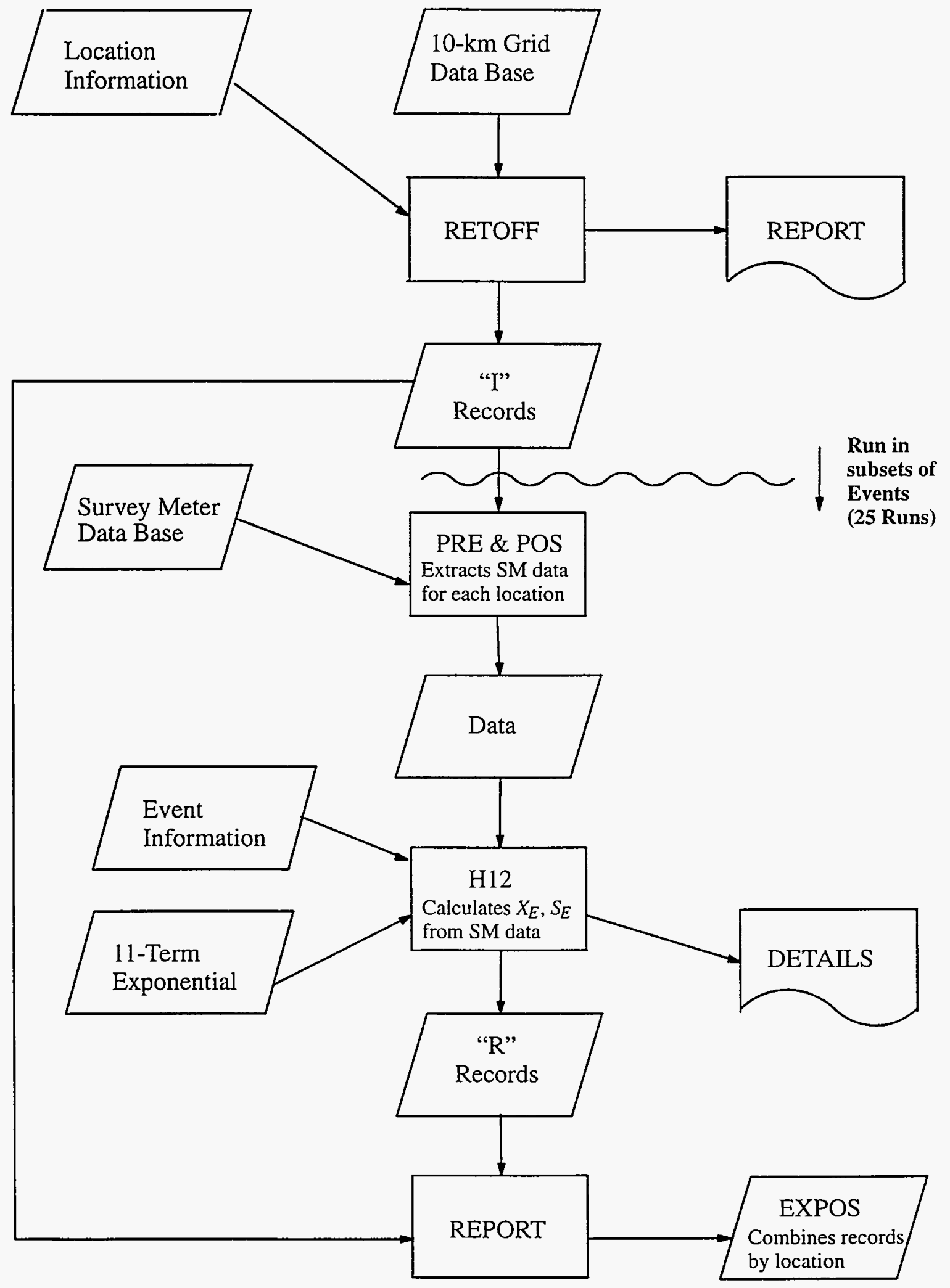

Figure 9. Flow diagram of the FATHER procedure. 


\subsection{REVIEWING THE ESTIMATES}

\subsubsection{Basic Philosophy}

More than 9,000 sets of estimates were generated by the FATHER procedure, but not all of them could be used in dose calculations. Often estimates were made from both the $10-\mathrm{km}$ grid and the survey meter data, and one or the other had to be chosen. Other estimates were considered questionable for one of several reasons. Thus, it was important to review the estimates and select the ones suitable for inclusion in the Town Data Base.

The most important criterion for including estimates in the data base was based on the concept of discernible fallout. As noted in Section 4.2, low levels of exposure rate are difficult to measure accurately. Discussions of this topic led to the decision to include in the Town Data Base only those estimates of geometric mean exposure rate $X_{E}$ that equaled or exceeded "discernible fallout." The definition of discernible fallout was taken to be three times the default background exposure rate for an event, that is, $0.15 \mathrm{mR} / \mathrm{hr}$ for event HARRY and $0.06 \mathrm{mR} / \mathrm{hr}$ for all other events.

For estimates that exceeded the level of discernible fallout, a hierarchy of information sources was established to determine which estimates would be used. Estimates of exposure rate calculated from the survey meter data were considered preferable because they were based on actual measurements made in the vicinity of the location of interest. Such estimates had the highest priority unless they were found to be inconsistent with estimates from other sources. Estimates based on the fallout patterns had second highest priority. Estimates from reports or other sources had lower priority and were only used if estimates calculated from the survey meter data were suspect. Estimates of time of fallout arrival were taken primarily from the fallout patterns and secondarily from reports or other sources.

The basic objective of the review was to ensure that the chosen estimates were "best" in the sense of being most consistent with the available sources of information. The process basically compared a location's estimates as produced in the FATHER runs with the fallout patterns and with estimates from nearby locations. Several secondary sources of information were also used to support the decisions made about the estimates. One source was the collection of off-site surveillance and radiological safety reports prepared after each event. These reports often contained information about the maximum exposure rate and the time of fallout arrival at several sites in the path of the cloud. They also provided commentary about unusual conditions.

Another important source of information for some locations was the County Data Base (Beck and Anspaugh, 1991). Although the Town Data Base was created to contain estimates for the Phase I region, many of the locations run through the estimation process described here were in the Phase II region. The resulting estimates for those locations were used as supplementary information in developing the County Data Base. Conversely, estimates from the County Data Base based on other sources of information were used to help resolve questions on the Town Data Base estimates. In fact, the estimates for fallout in Las Vegas from events APPLE-1, POST, SANFORD, and SOCORRO were produced by the methods used in Phase II. The fallout patterns for those events do not include Las Vegas, and survey meter data were not collected there because the city was upwind when the events were conducted. However, the gummed film data used for the County Data Base show that some fallout from those events did reach Las Vegas. To avoid giving an impression to the contrary, Beck and Anspaugh provided the necessary estimates for inclusion in the Town Data Base. 
During the review, it was important to recognize that the data were 30 to 40 years old and might contain errors which could not be resolved. Even the considerable review of data for the final version of the Survey Meter Data Base could not preclude errors in interpretation because of the lack of clarity of the information on the logs or the tedium of the encoding task. Although these were the best data available for the task, they do have limitations, and it is thus all the more important to consider uncertainty along with the actual estimate when the dose calculations are being made.

Any anomalies in the estimates or questions that could not be resolved were reviewed by the ORERP's Scientific Director, Dr. Lynn R. Anspaugh of Lawrence Livermore National Laboratory. Dr. Anspaugh's extensive background in the area of estimating radiation exposures, especially in connection with work at the NTS, provided additional insights into these questions. His directions for the assessment of a location's estimate were considered final.

\subsubsection{The Review Process}

The initial steps of the review were computerized to prevent having to check each estimate by hand, and to increase consistency and reduce subjectivity in the judgments to be made. The computer programs used several criteria to identify anomalies as potential indicators of errors that were not previously caught or of situations that had not been expected to influence the estimates. The purpose was to identify for review those estimates that met one or more of these criteria.

The first step in the review occurred during the FATHER procedure in program H12. After that program had calculated $X_{E}$ and $S_{E}$ values from the survey meter data, it assigned a case letter to each estimate. (Here and in the rest of this section, the word "estimate" refers collectively to the four estimated values $X_{E}, S_{E}, X_{T}$, and $S_{T}$.) The case letters provided an easy way to describe the estimate with respect to how many measurements were available, how many of them had net values of zero, whether or not the estimated $X_{E}$ was greater than discernible fallout, and so forth. The various cases are described in Table 1. In assigning the case letter, both the arithmetic and geometric mean of the data were examined, though only the geometric mean was actually used in an estimate. Also, note that an estimate was produced even if there were no usable survey meter data (Case A) to differentiate from the case where there were no data at all. The case letters were included in the printouts and records of the FATHER procedure and served as easy-to-recognize flags in the review.

The review process continued once all the estimates were created through FATHER. A flow diagram of the next steps is shown in Figure 10.

The first program in the post-FATHER procedure was DECCMB, which structured the estimates in the format of the Town Data Base. It also assigned a decision type and a tentative use code to each estimate. The decision type was based on the position of the location relative to the $10-\mathrm{km}$ grid rectangle and flagged area (see Figure 5) and the case letter assigned to estimates of $X_{E}$ from the survey meter data. The various decision types are defined in Table 2. They basically describe the existence and kinds of estimates available from both major sources for a given location. If a location had a record from both the $10-\mathrm{km}$ grid (I record) and the survey meter data (R record), each record was given the same decision type. The distribution of decision types from the initial FATHER run is also shown in Table 2.

The result of DECCMB was a set of potential records for the Town Data Base, with many locations having two records ( $\mathrm{I}$ and $\mathrm{R}$ ). The rest of the review process eliminated the records whose estimates did not meet various criteria. The use code assigned by DECCMB was a preliminary judgment as to whether the record should be used, but was subject to change upon further review. 
Table 1. Case Letters Assigned to Estimates from Survey Meter Data

\begin{tabular}{|c|c|c|c|c|c|c|c|}
\hline $\begin{array}{l}\text { Case } \\
\text { Letter }\end{array}$ & $\frac{\# \text { of } r}{\text { Total }}$ & $\frac{e a s u r e}{N=0}$ & $\frac{\text { nents }^{a}}{N>0}$ & $\begin{array}{l}\text { Relationship } \\
\text { of mean } \\
\text { to } \mathrm{DF}^{\mathrm{b}}\end{array}$ & $X_{E}$ & $S_{E}$ & Use \\
\hline $\bar{A}$ & 0 & - & - & - & -999 & -999 & No \\
\hline B & 1 & 0 & 1 & $<\mathrm{DF}$ & $\mathrm{GM}^{\mathrm{c}}$ & 0 & No \\
\hline C & 1 & 0 & 1 & $\geq \mathrm{DF}$ & GM & 1 & Yes \\
\hline D & $\mathrm{n}$ & $\mathrm{n}$ & 0 & - & 0 & 0 & No \\
\hline E & $\mathrm{p}$ & 0 & $\mathrm{p}$ & $<\mathrm{DF}$ & GM & 0 & No \\
\hline $\mathrm{F}$ & $\mathrm{p}$ & 0 & $\mathrm{p}$ & $\geq \mathrm{DF}$ & GM & $\mathrm{GSD}^{\mathrm{d}}$ & Yes \\
\hline G & $\mathrm{n}$ & $\mathrm{m}$ & $\mathrm{n}-\mathrm{m}$ & $<\mathrm{DF}$ & GM & 0 & No \\
\hline $\mathrm{H}$ & $\mathrm{n}$ & $\mathrm{m}$ & $n-m$ & $\geq \mathrm{DF}$ & GM & GSD & Yes \\
\hline I & $\mathrm{n}$ & 0 & $n$ & $\begin{array}{l}\mathrm{AM} \geq \mathrm{DF}^{\mathrm{e}} \\
0<\mathrm{GM}<\mathrm{DF}\end{array}$ & GM & 0 & No \\
\hline $\mathbf{J}$ & $\mathrm{n}$ & $\mathrm{m}$ & $\mathrm{n}-\mathrm{m}$ & $\begin{array}{l}\mathrm{AM} \geq \mathrm{DF} \\
0<\mathrm{GM}<\mathrm{DF}\end{array}$ & GM & 0 & No \\
\hline
\end{tabular}

${ }^{a} \mathrm{~N}-$ Net value for measurement $=$ gross value - background value; $p \geq 2, n \geq 1, m>0$

bDF - Discernible Fallout

${ }^{c} \mathrm{GM}$ - Geometric Mean

${ }^{d} \mathrm{GSD}$ - Geometric Standard Deviation

${ }^{\mathrm{e}} \mathrm{AM}$ - Arithmetic Mean

Table 2. Definitions of Decision Types

\begin{tabular}{|c|c|c|c|c|}
\hline $\begin{array}{l}\text { Decision } \\
\text { Type }\end{array}$ & $\begin{array}{l}\text { Location Relative } \\
\text { to } 10-\mathrm{km} \text { Grid }\end{array}$ & $\begin{array}{l}X_{E} \text { Estimate from } \\
\text { Survey Meter Data }\end{array}$ & $\begin{array}{l}\text { Record } \\
\text { Types }\end{array}$ & $\begin{array}{c}\text { \# of } \\
\text { Locations }\end{array}$ \\
\hline 1 & inside flagged area & none & $\mathrm{I}$ & 881 \\
\hline 2 & inside flagged area & $\geq \mathrm{DF}^{\mathrm{a}}$ & $\mathrm{I}, \mathrm{R}$ & 801 \\
\hline 3 & inside flagged area & $<\mathrm{DF}$ & $\mathrm{I}, \mathrm{R}$ & 202 \\
\hline 4 & outside grid rectangle & $<\mathrm{DF}$ & $\mathrm{R}$ & 2133 \\
\hline 5 & $\begin{array}{l}\text { inside grid rectangle, } \\
\text { outside flagged area }\end{array}$ & none & $\mathrm{I}$ & 2073 \\
\hline 6 & $\begin{array}{l}\text { inside grid rectangle, } \\
\text { outside flagged area }\end{array}$ & $<\mathrm{DF}$ & $\mathrm{I}, \mathrm{R}$ & 680 \\
\hline 7 & $\begin{array}{l}\text { inside grid rectangle, } \\
\text { outside flagged area }\end{array}$ & $\geq \mathrm{DF}$ & $\mathrm{I}, \mathrm{R}$ & 256 \\
\hline 8 & outside grid rectangle & $\geq \mathrm{DF}$ & $\mathrm{R}$ & $\frac{181}{7207}$ \\
\hline
\end{tabular}

aDF - Discernible Fallout 


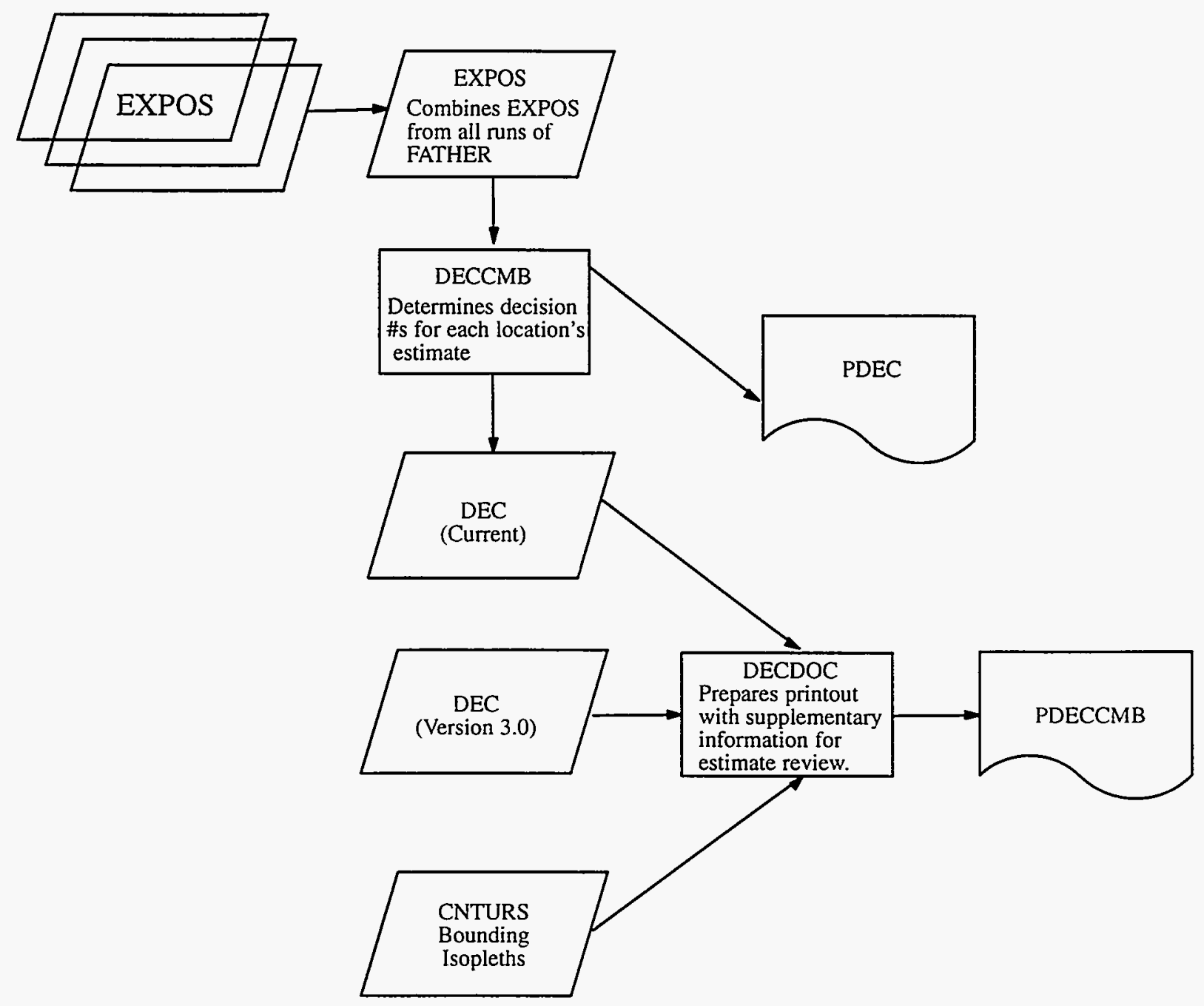

Figure 10. Flow diagram of the post-FATHER procedure leading to the PDECCMB printout for reviewing the estimates.

The next step was to process the estimates through program DECDOC, which produced one of the primary printouts (PDECCMB) used in the review process. The input to DECDOC included the bounding isopleths (the levels of the upper and lower isopleths of both exposure rate and arrival time that bounded a location) for each location within the flagged area of an event (file CNTURS). The DECDOC program also extracted the estimates from the previous FATHER run for comparison to those from the current run. The PDECCMB printout included, for every location, all estimates from both the $10-\mathrm{km}$ grid and the survey meter data from the previous and current runs of FATHER, the decision type for each estimate, and the bounding isopleth levels.

DECDOC also determined whether an $X_{E}$ or $X_{T}$ value was more than 25 percent outside either of its bounding isopleth levels. For example, if a location fell between the $1 \mathrm{mR} / \mathrm{hr}$ and $4 \mathrm{mR} / \mathrm{hr}$ exposure rate isopleths, the $X_{E}$ value would be compared to $0.75 \mathrm{mR} / \mathrm{hr}$ and $5.0 \mathrm{mR} / \mathrm{hr}$. If it was outside those bounds, that is, if it was smaller than the lower value or larger than the higher value, 
the printout would so indicate. This check on the isopleth bounds was one of the criteria used to identify estimates for review.

At this point, enough information and processing of estimates had been produced to begin the detailed review. The protocol identified criteria for whether the estimates for a location would or would not be reviewed. The primary estimate reviewed for a location was the one with highest priority (Section 5.2.1). If there were both an I and an $\mathrm{R}$ record for a location, the non-primary estimate would be reviewed as supporting information for a perceived anomaly.

Given the effort put into creating and reviewing the estimates, it was important to track, for potential historical review, decisions made about changes to estimates or their inclusion in the Town Data Base. If a location's estimate was to be reviewed, or if the results of the FATHER run were changed for any reason, a Decision Tracking Sheet (Figure 11) was filled out. This sheet tracked, with handwritten notes, the reason for the review, steps that were taken, pertinent information gleaned from other information sources, decisions made, and changes made to the estimate records. Entries were dated and initialed by the person making the entry. Some 1,300 Decision Tracking Sheets were produced during creation of the data base. The sheets and the checking printout (PDECCMB) have been archived in folders by event to document every estimate in the Town Data Base.

\subsubsection{Criteria for Review}

The estimate for a location was reviewed if any of the following conditions occurred:

- The estimate of $X_{E}$ or $X_{T}$ was more than 25 percent outside the bounding isopleth.

- The estimate of $X_{E}$ was at or above the level of discernible fallout, but the location was outside the flagged area on the fallout pattern.

- The estimate of $S_{E}$ was 2.0 or greater, indicating an unusual amount of variability in the data.

- The estimate of $X_{T}$ was less than $0.75 \mathrm{hr}$ or greater than or equal to $30 \mathrm{hr}$.

The following paragraphs give details concerning the review of estimates from the two sources.

Estimates from the $10-\mathrm{km}$ grid were considered usable if they were consistent with other information sources. The situation that most often caused these estimates to be checked was that they were more than 25 percent outside the bounding isopleths for a location on the fallout map. In some cases the $X_{T}$ value fell within these bounds but the $X_{E}$ estimate from the survey meter data, which depends on $X_{T}$, was anomalous.

There are two main reasons why an estimate from the 10-km grid might seem anomalous. First, the isopleths may have been very close so that more than one isopleth level fell between the grid nodes which were $10 \mathrm{~km}$ apart (an example is the region near the grid node with a value of .6 in Figure 6). This meant that the gradient of the isopleths was very steep and information provided to the interpolant forced it to create node estimates that had a wide range of values in a small area. Second, a node along the edge that represented an upturn in the gradient may have been mistakenly flagged for use. A node with a higher than usual kriging error for $X_{E}$, which should have been flagged as unusable, may also not have been caught.

In either case, the values at the nodes were compared to the isopleth levels. In the first case, this was a verification of the situation and a change was made only if the criteria for flagging a node's 
Town Data Base - 1989

Decision Tracking Sheet

DTS \#

Event Name:

Event \#

Event Subset

Location Name:

Ctrl \#

Run \#

Original Decision \#:

Case, if applicable:

Original Reviewer:

Date:

Reason for Review:

Use the remainder of this sheet and the next to describe what was checked, what was found, what was done in response to that and what decisions were made. Please reference computer file names for reruns and printout \#s used as reference or obtained as output from a rerun. Date and initial your comments here. The DTS \#, final decision and estimates should be marked on the PDECCMB listing. Copies of pages from printouts or other supporting documents can be attached to make the explanations easier to understand. Please mark each of these sheets with the DTS \# and a letter for reference purposes.

Town Data Base - 1989

Decision Tracking Sheet

DTS \#

Event \#

Ctrl \#

$\operatorname{Pg} 2$

Figure 11. The Decision Tracking Sheet used to document the review of the estimates. 
usability had not been adhered to. If the flags were changed, the affected estimates were rerun. There were only two incidents in the whole review where flags were changed. If the flags were not changed, the estimates were left as is and the review process was documented on the Decision Tracking Sheet.

When estimates from the survey meter data were selected for review, all pertinent sources of information were considered in attempting to resolve the potential anomaly: original logs or reports, encoding of data, estimates from the County Data Base, estimates from nearby locations, and whether $X_{T}$ was from the $10-\mathrm{km}$ grid or from a visual estimate. The possible causes of anomalies and the steps taken to try to resolve them included the following:

1. Data that were suspect because of conditions noted on the logs or because of the encoding of the data.

Steps: Correct the erroneous data or flag the data as not usable and rerun the estimate.

2. Circumstances such as weather conditions noted in reports or logs.

Step: Determine whether to use the estimate based on the effect of the circumstances. For example, high winds might cause resuspension of fallout and an unusually high exposure rate well after the time of fallout arrival.

3. A measurement less than the discernible fallout level was taken more than 60 hours after the event.

Step: Rerun the estimate excluding the measurement.

4. $X_{T}$ was too low based on the distribution of exposure rate values (that is, measurements taken before the fallout cloud arrived were included in the estimate of $X_{E}$ so that either $X_{E}$ was outside the isopleth bounds or $S_{E}$ exceeded 2.0).

Steps: If $X_{T}$ was estimated from the $10-\mathrm{km}$ grid, check the values at the grid nodes. If they are consistent with the isopleths, multiply $X_{T}$ by 1.1 and rerun the $X_{E}$ estimate. If $X_{T}$ was not estimated from the grid or the first step still leaves an anomaly, review the distribution of the available measurements or review reports to create a new estimate of $X_{T}$ and rerun the estimate.

5. Closeness of the isopleths indicated a steep gradient in a small area.

Steps: Confirm the variability of the measurements with respect to their distance from the location and the gradient represented on the fallout pattern. Identify measurements for further review and rerun the estimate if necessary.

6. Possible residual fallout from an earlier event.

Steps: Look at events that occurred within 75 days earlier that have an $X_{E}$ value greater than the $X_{E}$ value in review. Decay-correct any such previous values to $\mathrm{H}+12$ on the day of the current event, and compare each decay-corrected previous value to the current value: 
If a previous value is within an order of magnitude of the current value, consider the current value to represent fallout from the previous event and do not use it.

If a previous value is much lower than the current value, subtract the decay-corrected value for the previous event from the value for the current event, and use the difference as the new value of $X_{E}$. Set $S_{E}$ to the default value of 1.4 .

If a previous value is much higher than the current value, consider the current value as representing the fallout level from the previous event, based on review of other information sources.

If an apparent anomaly was not resolved with steps from the review described above, the estimate was reviewed by the ORERP's Scientific Director. The final decision about whether to include the estimate in the TDB was based on his judgment. 


\section{THE TOWN DATA BASE}

The Town Data Base includes the following information for 1,910 combinations of populated location and nuclear event where the estimated mean $\mathrm{H}+12$ exposure rate exceeded the level of discernible fallout:

Location:

Event:

Parameter Estimates:

Other: control number, state, county, township, location name, Universal Transverse Mercator coordinates, latitude, longitude

name, date

$X_{E}, S_{E}, X_{T}, S_{T}$

source of estimate, date of FATHER run, number of points, decision type, use code

The format of the records in the data base is given in Appendix B. Appendix C contains a list of the estimates in the Town Data Base sorted by state, county, and location. The number of events for which a location has an estimate differs from one location to another because of the varied paths taken by the fallout from the events and the places where survey meter measurements were taken.

The 604 locations in Arizona, California, Nevada, and Utah for which we attempted to make estimates are shown on Figure 12. Of these locations, the 353 shown on Figure 13 have at least one estimate in the Town Data Base. Table 3 gives a breakdown of those locations by county. The remaining locations did not receive a discernible amount of fallout from any NTS event.

Of the 77 nuclear events for which fallout patterns were available, 67 have an estimate for at least one location in the Town Data Base. We were able to make at least one estimate for 7 additional events from the survey meter data, so the total number of events represented in the data base is 74 . Survey meter data exist for 70 of those events. Table 4 lists all the events used in creating the Town Data Base along with the number of locations with estimates for those events.

The Town Data Base represents the culmination of a 13-year effort by the Desert Research Institute staff to produce the best possible estimates of exposure rate and time of fallout arrival locations near the NTS from the available historical data. This effort included the development of the estimation methods, the quality assessment of relevant input data bases, and a detailed review of the estimates. At the close of this task, these estimates have been used by the ORERP External Dose, Pathway Analysis, and Internal Dose task groups to produce estimates of radiation dose. The methodology used to create the Town Data Base can be used to generate estimates for other locations with relative ease. All the programs, data, and documentation for the data base have been archived at the Coordination and Information Center for future use if the need arises. 


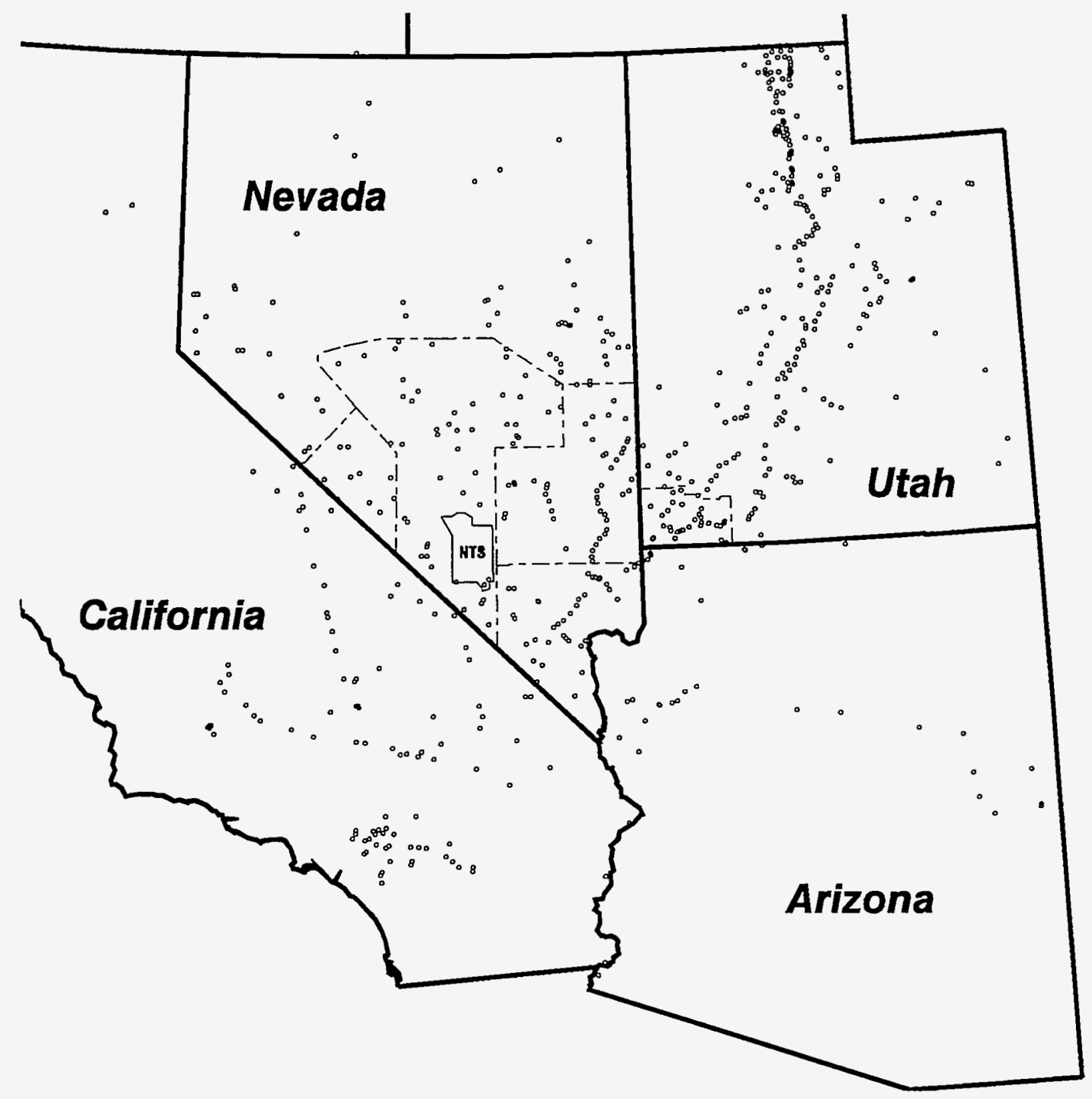

Figure 12. Locations for which estimates were attempted. The dashed lines outline the five counties in the ORERP Phase I region. 


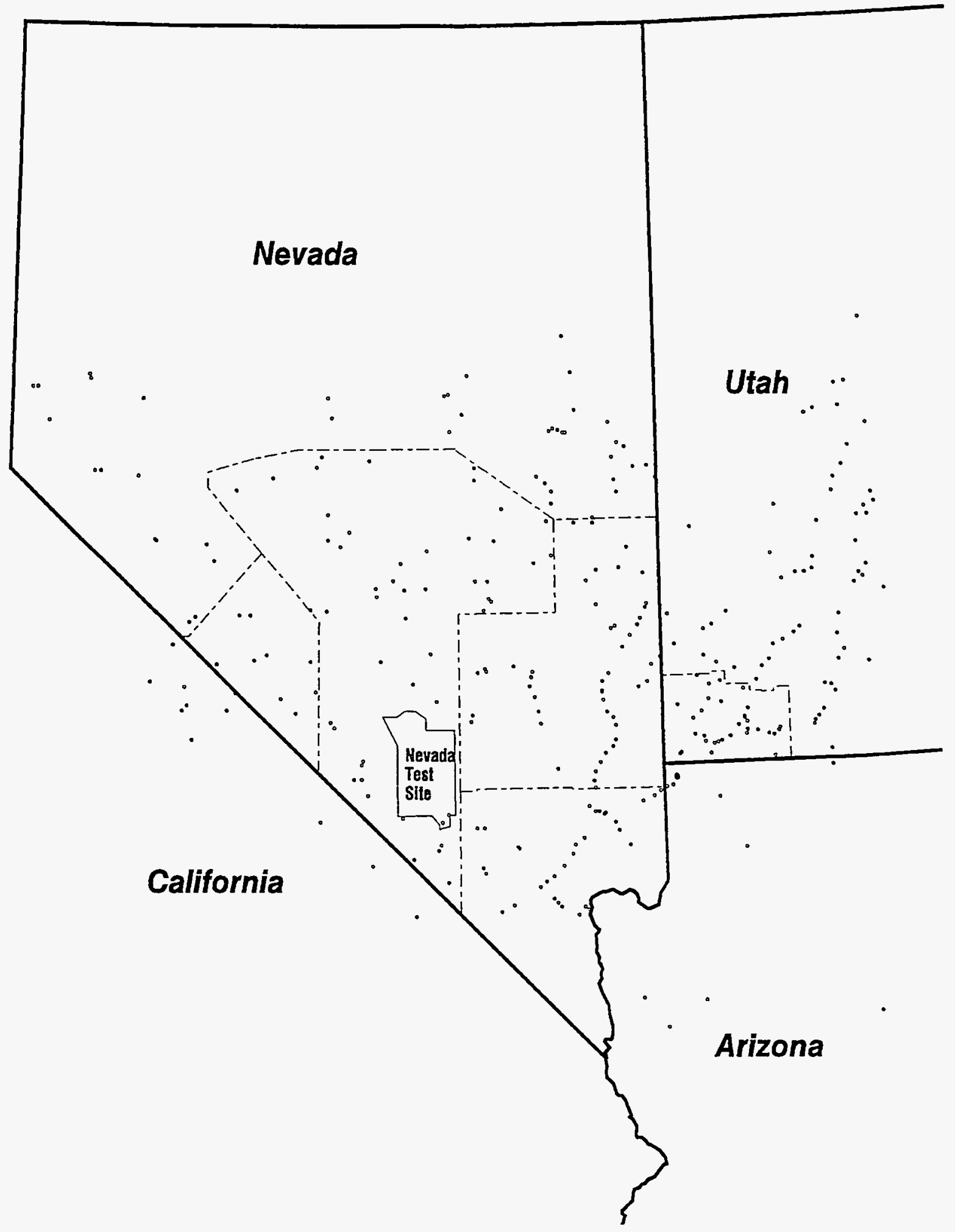

Figure 13. Locations for which the Town Data Base contains estimates. 
Table 3. Distribution of Locations Used to Create the Town Data Base

\begin{tabular}{|c|c|c|c|}
\hline State & County & $\begin{array}{l}\text { \# Locations } \\
\text { Attempted }\end{array}$ & $\begin{array}{l}\text { \# Locations in } \\
\text { Town Data Base }\end{array}$ \\
\hline \multirow[t]{6}{*}{ Arizona } & Apache & 4 & 0 \\
\hline & Coconino & 4 & 2 \\
\hline & Mohave & 27 & 12 \\
\hline & Navajo & 4 & 0 \\
\hline & Yuma & 4 & 0 \\
\hline & & 43 & 14 \\
\hline \multirow[t]{7}{*}{ California } & Inyo & 17 & 7 \\
\hline & Kern & 21 & 0 \\
\hline & Lassen & 2 & 0 \\
\hline & Mono & 5 & 4 \\
\hline & Riverside & 24 & 0 \\
\hline & San Bernardino & 32 & 0 \\
\hline & & 101 & 11 \\
\hline \multirow[t]{18}{*}{ Nevada } & Churchill & 1 & 1 \\
\hline & Clark & 39 & 33 \\
\hline & Douglas & 1 & 0 \\
\hline & Elko & 3 & 1 \\
\hline & Esmeralda & 9 & 9 \\
\hline & Eureka & 3 & 3 \\
\hline & Humboldt & 4 & 0 \\
\hline & Lander & 2 & 2 \\
\hline & Lincoln & 47 & 47 \\
\hline & Lyon & 3 & 3 \\
\hline & Mineral & 7 & 7 \\
\hline & Nye & 52 & 52 \\
\hline & Ormsby (Carson City) & 1 & 0 \\
\hline & Pershing & 1 & 0 \\
\hline & Storey & 1 & 1 \\
\hline & Washoe & 3 & 3 \\
\hline & White Pine & 23 & 23 \\
\hline & & $\overrightarrow{200}$ & 185 \\
\hline \multirow[t]{10}{*}{ Utah } & Beaver & 6 & 6 \\
\hline & Box Elder & 18 & 0 \\
\hline & Cache & 19 & 0 \\
\hline & Carbon & 8 & 6 \\
\hline & Daggett & 1 & 0 \\
\hline & Davis & 16 & 0 \\
\hline & Duchesne & 5 & 5 \\
\hline & Emery & 8 & 5 \\
\hline & Garfield & 10 & 6 \\
\hline & Grand & 1 & 0 \\
\hline
\end{tabular}


Table 3. (continued.)

\begin{tabular}{llcc}
\hline State & County & $\begin{array}{c}\text { \# Locations } \\
\text { Attempted }\end{array}$ & $\begin{array}{c}\text { \# Locations in } \\
\text { Town Data Base }\end{array}$ \\
\hline Utah & Iron & 16 & 16 \\
& Juab & 4 & 4 \\
& Kane & 8 & 8 \\
Millard & 14 & 14 \\
Morgan & 1 & 0 \\
& Piute & 5 & 5 \\
Rich & 5 & 0 \\
Salt Lake & 11 & 0 \\
San Juan & 2 & 0 \\
& San Pete & 13 & 13 \\
Sevier & 11 & 8 \\
& Summit & 6 & 4 \\
Tooele & 5 & 0 \\
& Uintah & 2 & 0 \\
Utah & 15 & 7 \\
& Wasatch & 4 & 4 \\
Washington & 32 & 32 \\
& Wayne & 4 & 0 \\
Weber & 10 & 0 \\
& 260 & 143 \\
\hline
\end{tabular}


Table 4. Events Used to Create the Town Data Base

\begin{tabular}{|c|c|c|c|c|c|c|}
\hline \multirow[b]{2}{*}{ Event } & \multirow[b]{2}{*}{ Date } & \multicolumn{4}{|c|}{ \# of Locations } & \multirow[b]{2}{*}{ Total } \\
\hline & & $\mathrm{AZ}$ & $\mathrm{CA}$ & NV & UT & \\
\hline \multicolumn{7}{|l|}{ Operation Jangle } \\
\hline SUGAR & $11 / 19 / 51$ & 0 & 0 & 40 & 0 & 40 \\
\hline UNCLE & $11 / 29 / 51$ & 0 & 0 & 45 & 0 & 45 \\
\hline \multicolumn{7}{|l|}{ Operation Tumbler-Snapper } \\
\hline CHARLIE $^{\mathrm{a}}$ & $04 / 22 / 52$ & 0 & 0 & 1 & 0 & 1 \\
\hline $\mathrm{DOG}^{\mathrm{a}}$ & $05 / 01 / 52$ & 0 & 0 & 4 & 0 & 4 \\
\hline EASY & $05 / 07 / 52$ & 0 & 0 & 34 & 0 & 34 \\
\hline FOX & $05 / 25 / 52$ & 0 & 0 & 33 & 33 & 66 \\
\hline GEORGE & $06 / 01 / 52$ & 0 & 0 & 27 & 0 & 27 \\
\hline HOW & $06 / 05 / 52$ & 0 & 0 & 27 & 0 & 27 \\
\hline \multicolumn{7}{|l|}{ Operation Upshot Knothole } \\
\hline ANNIE & $03 / 17 / 53$ & 4 & 0 & 11 & 25 & 40 \\
\hline NANCY & $03 / 24 / 53$ & 0 & 0 & 42 & 0 & 42 \\
\hline RUTH ${ }^{b}$ & $03 / 31 / 53$ & 0 & 0 & 0 & 0 & 0 \\
\hline $\mathrm{DIXIE}^{\mathrm{a}}$ & $04 / 06 / 53$ & 0 & 0 & 0 & 1 & 1 \\
\hline RAY & $04 / 11 / 53$ & 0 & 0 & 1 & 0 & 1 \\
\hline BADGER & $04 / 18 / 53$ & 5 & 0 & 19 & 0 & 24 \\
\hline SIMON & $04 / 25 / 53$ & 5 & 0 & 32 & 18 & 55 \\
\hline HARRY & $05 / 19 / 53$ & 7 & 0 & 31 & 47 & 85 \\
\hline GRABLE & $05 / 25 / 53$ & 0 & 0 & 28 & 0 & 28 \\
\hline CLIMAX & $06 / 04 / 53$ & 1 & 0 & 15 & 0 & 16 \\
\hline \multicolumn{7}{|l|}{ Operation Teapot } \\
\hline MOTH & $02 / 22 / 55$ & 0 & 0 & 3 & 0 & 3 \\
\hline TESLA & $03 / 01 / 55$ & 2 & 0 & 18 & 24 & 44 \\
\hline TURK & $03 / 07 / 55$ & 0 & 0 & 66 & 6 & 72 \\
\hline HORNET & $03 / 12 / 55$ & 4 & 0 & 28 & 2 & 34 \\
\hline BEE & $03 / 22 / 55$ & 1 & 0 & 10 & 0 & 11 \\
\hline ESS & $03 / 23 / 55$ & 4 & 0 & 15 & 2 & 21 \\
\hline APPLE-1 & $03 / 29 / 55$ & 0 & 0 & 28 & 27 & 55 \\
\hline POST & $04 / 09 / 55$ & 0 & 0 & 18 & 0 & 18 \\
\hline MET & $04 / 15 / 55$ & 0 & 0 & 19 & 26 & 45 \\
\hline APPLE-2 & $05 / 05 / 55$ & 0 & 0 & 56 & 20 & 76 \\
\hline ZUCCHINI & $05 / 15 / 55$ & 4 & 0 & 21 & 33 & 58 \\
\hline \multicolumn{7}{|l|}{ Operation Plumbbob } \\
\hline BOLTZMANN & $05 / 28 / 57$ & 0 & 1 & 48 & 0 & 49 \\
\hline WILSON & $06 / 18 / 57$ & 0 & 1 & 21 & 0 & 22 \\
\hline PRISCILLA & $06 / 24 / 57$ & 1 & 0 & 20 & 44 & 65 \\
\hline HOOD & $07 / 05 / 57$ & 0 & 0 & 33 & 17 & 50 \\
\hline DIABLO & $07 / 15 / 57$ & 0 & 0 & 49 & 1 & 50 \\
\hline $\mathrm{JOHN}^{\mathrm{a}}$ & $07 / 19 / 57$ & 0 & 0 & 1 & 1 & 2 \\
\hline KEPLER & $07 / 24 / 57$ & 0 & 8 & 24 & 0 & 32 \\
\hline OWENS & $07 / 25 / 57$ & 0 & 0 & 41 & 0 & 41 \\
\hline STOKES & $08 / 07 / 57$ & 0 & 0 & 1 & 0 & 1 \\
\hline SHASTA & $08 / 18 / 57$ & 0 & 0 & 39 & 0 & 39 \\
\hline DOPPLER & $08 / 23 / 57$ & 0 & 0 & 26 & 0 & 26 \\
\hline FRANKLIN PRIME & $08 / 30 / 57$ & 0 & 0 & 1 & 0 & 1 \\
\hline SMOKY & $08 / 31 / 57$ & 4 & 0 & 29 & 62 & 95 \\
\hline GALILEO & $09 / 02 / 57$ & 0 & 0 & 21 & 0 & 21 \\
\hline WHEELER $^{\mathrm{a}}$ & $09 / 06 / 57$ & 0 & 1 & 11 & 0 & 12 \\
\hline COULOMB-B & $09 / 06 / 57$ & 0 & 0 & 7 & 0 & 7 \\
\hline FIZEAU & $09 / 14 / 57$ & 0 & 0 & 12 & 0 & 12 \\
\hline
\end{tabular}


Table 4. (continued.)

\begin{tabular}{|c|c|c|c|c|c|c|}
\hline \multirow[b]{2}{*}{ Event } & \multirow[b]{2}{*}{ Date } & \multicolumn{4}{|c|}{ \# of Locations } & \multirow[b]{2}{*}{ Total } \\
\hline & & $\mathrm{AZ}$ & $\mathrm{CA}$ & $\mathrm{NV}$ & UT & \\
\hline NEWTON & $09 / 16 / 57$ & 0 & 0 & 16 & 3 & 19 \\
\hline WHITNEY & $09 / 23 / 57$ & 0 & 5 & 34 & 0 & 39 \\
\hline MORGAN & $10 / 07 / 57$ & 0 & 0 & 7 & 25 & 32 \\
\hline \multicolumn{7}{|l|}{ Operation Hardtack II } \\
\hline OTERO & $09 / 12 / 58$ & 0 & 0 & 0 & 0 & 0 \\
\hline EDDY & $09 / 19 / 58$ & 0 & 0 & 5 & 0 & 5 \\
\hline MORA $^{b}$ & $09 / 29 / 58$ & 0 & 0 & 0 & 0 & 0 \\
\hline HIDALGO & $10 / 05 / 58$ & 0 & 0 & 4 & 0 & 4 \\
\hline QUAY & $10 / 10 / 58$ & 0 & 2 & 5 & 0 & 7 \\
\hline LEA & $10 / 13 / 58$ & 0 & 0 & 11 & 0 & 11 \\
\hline HAMILTON & $10 / 15 / 58$ & 0 & 0 & 0 & 0 & 0 \\
\hline DONA ANA & $10 / 16 / 58$ & 0 & 0 & 0 & 0 & 0 \\
\hline VESTA & $10 / 17 / 58$ & 0 & 0 & 1 & 0 & 1 \\
\hline RIO ARRIBA & $10 / 18 / 58$ & 0 & 0 & 9 & 0 & 9 \\
\hline SOCORRO & $10 / 22 / 58$ & 0 & 0 & 1 & 0 & 1 \\
\hline WRANGELL & $10 / 22 / 58$ & 0 & 0 & 2 & 0 & 2 \\
\hline CATRON $^{\mathrm{b}}$ & $10 / 24 / 58$ & 0 & 0 & 0 & 0 & 0 \\
\hline DE BACA ${ }^{b}$ & $10 / 26 / 58$ & 0 & 0 & 0 & 0 & 0 \\
\hline SANFORD & $10 / 26 / 58$ & 0 & 0 & 2 & 0 & 2 \\
\hline CHAVEZ ${ }^{\mathrm{b}}$ & $10 / 27 / 58$ & 0 & 0 & 0 & 0 & 0 \\
\hline HUMBOLDT' & $10 / 29 / 58$ & 0 & 0 & 0 & 0 & 0 \\
\hline SANTA FE ${ }^{b}$ & $10 / 29 / 58$ & 0 & 0 & 0 & 0 & 0 \\
\hline \multicolumn{7}{|l|}{ Operation Nougat } \\
\hline ANTLER $^{\mathrm{a}}$ & $09 / 15 / 61$ & 0 & 0 & 2 & 0 & 2 \\
\hline DANNY BOY & 03/05/62 & 0 & 0 & 3 & 0 & 3 \\
\hline PLATTE & $04 / 14 / 62$ & 0 & 0 & 10 & 0 & 10 \\
\hline EEL & $05 / 19 / 62$ & 0 & 0 & 2 & 0 & 2 \\
\hline DES MOINES & $06 / 13 / 62$ & 0 & 0 & 11 & 0 & 11 \\
\hline \multicolumn{7}{|l|}{ Operation Storax } \\
\hline SEDAN & $07 / 06 / 62$ & 0 & 0 & 31 & 0 & 31 \\
\hline \multicolumn{7}{|l|}{ Operation Sunbeam } \\
\hline JOHNIE BOY & $07 / 11 / 62$ & 0 & 0 & 11 & 0 & 11 \\
\hline SMALL BOY & $07 / 14 / 62$ & 0 & 0 & 31 & 72 & 103 \\
\hline \multicolumn{7}{|l|}{ Operation Storax } \\
\hline BANDICOOT & $10 / 19 / 62$ & 0 & 1 & 15 & 0 & 16 \\
\hline \multicolumn{7}{|l|}{ Operation Niblick } \\
\hline PIKE & $03 / 13 / 64$ & 0 & 0 & 2 & 0 & 2 \\
\hline \multicolumn{7}{|l|}{ Operation Whetstone } \\
\hline SULKYa & $12 / 18 / 64$ & 0 & 0 & 1 & 0 & 1 \\
\hline PALANQUIN & $04 / 14 / 65$ & 0 & 0 & 13 & 0 & 13 \\
\hline \multicolumn{7}{|l|}{ Operation Flintlock } \\
\hline PIN STRIPE & $04 / 25 / 66$ & 0 & 0 & 6 & 0 & 6 \\
\hline \multicolumn{7}{|l|}{ Operation Crosstie } \\
\hline CABRIOLET & $01 / 26 / 68$ & 0 & 0 & 3 & 0 & 3 \\
\hline BUGGY & $03 / 12 / 68$ & 0 & 0 & 2 & 0 & 2 \\
\hline \multicolumn{7}{|l|}{ Operation Bowline } \\
\hline SCHOONER & $12 / 08 / 68$ & 0 & 0 & 43 & 7 & 50 \\
\hline Operation Emery & & & & & & \\
\hline BANEBERRY & $12 / 18 / 70$ & 0 & 0 & 14 & 0 & 14 \\
\hline
\end{tabular}

Notes:

"No fallout pattern was published (7 events)

${ }^{b} \mathrm{~A}$ fallout pattern was published, but no estimates of discernible fallout could be made ( 10 events) 


\section{REFERENCES}

Aitchison, J. and J.A.C. Brown, 1957. The Lognormal Distribution. Cambridge University Press, Cambridge, England.

Anspaugh, L.R., 1981. Stochastic modeling, assumptions and uncertainties, use of ICRP models for internal dose calculations. In Reporter's Transcript of Fourth Dose Assessment Advisory Group Meeting. U.S. Department of Energy, Nevada Operations Office, Las Vegas, Nevada. CIC \#017836.

Beck, H.L. and L.R. Anspaugh, 1991. Development of the County Data Base: estimates of exposure rates and times of arrival of fallout in the ORERP Phase-II area. Comparison with cumulative deposition-density estimates based on analyses of retrospective and historical soil samples. DOE/NV-320, U.S. Department of Energy, Nevada Operations Office, Las Vegas, Nevada. CIC \#091555.

Chiles, J.P., 1975. GAMMA: a program for computing semi-variograms. Center for Geostatistics, Fontainebleau, France.

Church, B.W., D.L. Wheeler, C.M. Campbell, R.V. Nutley and L.R. Anspaugh, 1990. Overview of the Department of Energy's Off-Site Radiation Exposure Review Project (ORERP). Health Phys. 59:503-510. CIC \#058001

Collison, T.D., 1953. Report to the test director: radiological safety operation: Operation Upshot-Knothole, Nevada Proving Grounds, March-June, 1953, WT-702 (REF). Field Command, Armed Forces Special Weapons Project, Albuquerque, New Mexico. CIC \#004347.

David, M., 1977. Geostatistical Ore Reserve Estimation. Elsevier Scientific Publishing Co., Amsterdam.

Delfiner, P. and J.P. Delhomme, 1975. Optimum interpolation by kriging. In J.C. Davis and M.J. McCullagh, eds., Display and Analysis of Spatial Data. John Wiley and Sons, Inc., London.

Delfiner, P., J.P. Delhomme and J.P. Chiles, 1976. BLUEPACK. Ecole Nationale Superieure des Mines de Paris, Fontainebleau, France.

Foley, T.A., Jr., 1981. Off-Site Radiation Exposure Review Project: Computer-aided surface interpolation and graphical display. DOE/DP/01253-45021, Water Resources Center, Desert Research Institute, Las Vegas, Nevada.

Freund, J.E., 1971. Mathematical Statistics. Prentice-Hall, Englewood Cliffs, New Jersey.

Friesen, H.N., 1985. Off-Site Radiation Exposure Review Project Fact Book. U.S. Department of Energy, Nevada Operations Office, Las Vegas, Nevada. CIC \#041478.

Goeke, R.H., 1958. Fallout patterns, Operation Plumbbob. U.S. Atomic Energy Commission, Las Vegas, Nevada. CIC \#000324. 
Grossman, R.F. and C.B. Thompson, 1993. Creation of a data base of survey meter readings in the western United States after nuclear tests. EPA/600/R-93/034, U.S. Environmental Protection Agency, Las Vegas, Nevada. CIC \#091725.

Henderson, R.W. and R.F. Smale, 1990. External exposure estimates for individuals near the Nevada Test Site. Health Phys. 59:715-721. CIC \#058019.

Hicks, H.G., 1981. Results of calculations of external gamma exposure rates from fallout and the related radionuclide compositions. UCRL-53152, Parts 1 through 8. Lawrence Livermore National Laboratory, Livermore, California. CIC \#017964-017971.

Journel, A.G. and Ch.J. Huijbregts, 1978. Mining Geostatistics. Academic Press, London.

Kennedy, N.C., 1981. Derivation of particle fallout times. In Reporter's Transcript of Fourth Dose Assessment Advisory Group Meeting, U.S. Department of Energy, Nevada Operations Office, Las Vegas. CIC \#017836.

Miller, F.L., 1982. Time of arrival position paper. In Reporter's Transcript of Fifth Dose Assessment Advisory Group Meeting, U.S. Department of Energy, Nevada Operations Office, Las Vegas. CIC \#018082.

Nagler, K.M. and K. Telegadas, 1956. The distribution of significant fallout from Nevada tests. U.S. Weather Bureau, Washington, D.C. CIC \#000690.

Placak, O.R., 1962. Final off-site report of the Project Sedan event. PNE-200F, U.S. Public Health Service, Las Vegas, Nevada. CIC \#0006211.

Quinn, V.E., 1986a. Analysis of Operation Upshot-Knothole nuclear test BADGER radiological and meteorological data. NVO-299, National Oceanic and Atmospheric Administration, Weather Service Nuclear Support Office, Las Vegas, Nevada. CIC \#061770.

Quinn, V.E., 1986b. Analysis of Operation Teapot nuclear test BEE radiological and meteorological data. NVO-304, National Oceanic and Atmospheric Administration, Weather Service Nuclear Support Office, Las Vegas, Nevada. CIC \#065155.

Quinn, V.E., 1987. Analysis of Operation Teapot nuclear test ZUCCHINI radiological and meteorological data. NVO-307, National Oceanic and Atmospheric Administration, Weather Service Nuclear Support Office, Las Vegas, Nevada. CIC \#065161.

Quinn, V.E., 1990. Analysis of meteorological and radiological data for selected fallout episodes. Health Phys. 59:577-592. CIC \#058009.

Quinn, V.E., V.D. Urban and N.C. Kennedy, 1981. Analysis of Upshot-Knothole 9 (HARRY) radiological and meteorological data. NVO-233, National Oceanic and Atmospheric Administration, Weather Service Nuclear Support Office, Las Vegas, Nevada. CIC \#015206.

Quinn, V.E., N.C. Kennedy and V.D. Urban, 1982. Analysis of Operation Plumbbob nuclear test SMOKY radiological and meteorological data. NVO-249, National Oceanic and Atmospheric Administration, Weather Service Nuclear Support Office, Las Vegas, Nevada. CIC \#039770. 
Quinn, V.E., N.C. Kennedy and C.R. Steadman, Jr., 1984. Analysis of Operation Dominic II nuclear test SMALL BOY radiological and meteorological data. NVO-285, National Oceanic and Atmospheric Administration, Weather Service Nuclear Support Office, Las Vegas, Nevada. CIC \#040033.

Quinn, V.E., V.D. Urban and N.C. Kennedy, 1986. Analysis of Operation Tumbler-Snapper nuclear test EASY radiological and meteorological data. NVO-297, National Oceanic and Atmospheric Administration, Weather Service Nuclear Support Office, Las Vegas, Nevada. CIC \#061769.

Richardus, P. and R.K. Adler, 1972. Map Projections for Geodesists, Cartographers and Geographers. North-Holland Publishing Co., Amsterdam.

Steadman, C.R., Jr., 1988. Analysis of Operation Upshot-Knothole nuclear test SIMON radiological and meteorological data. NVO-315, National Oceanic and Atmospheric Administration, Weather Service Nuclear Support Office, Las Vegas, Nevada. CIC \#51858.

Steadman, C.R., Jr., N.C. Kennedy and V.E. Quinn, 1983a. Analysis of Upshot-Knothole 1 (ANNIE) radiological and meteorological data. NVO-254, National Oceanic and Atmospheric Administration, Weather Service Nuclear Support Office, Las Vegas, Nevada. CIC \#040333.

Steadman, C.R., Jr., N.C. Kennedy and V.E. Quinn, 1983b. Analysis of Operation Plumbbob nuclear test BOLTZMANN radiological and meteorological data. NVO-260, National Oceanic and Atmospheric Administration, Weather Service Nuclear Support Office, Las Vegas, Nevada. CIC \#041637.

Steadman, C.R., Jr., N.C. Kennedy and V.E. Quinn, 1984a. Analysis of Operation Plumbbob nuclear test SMOKY aerial radiological data. NVO-275, National Oceanic and Atmospheric Administration, Weather Service Nuclear Support Office, Las Vegas, Nevada. CIC \#041758.

Steadman, C.R., Jr., N.C. Kennedy and V.E. Quinn, 1984b. Analysis of Operation Upshot-Knothole nuclear test NANCY radiological and meteorological data. NVO-282, National Oceanic and Atmospheric Administration, Weather Service Nuclear Support Office, Las Vegas, Nevada. CIC $\# 65159$.

Telegadas, K. and K.M. Nagler, 1960. Fallout patterns from Operation Hardtack, Phase II. U.S. Weather Bureau, Washington, D.C. CIC \#000323.

U.S. Department of Energy, 1989. Announced United States nuclear tests, July 1945 through December 1988. NVO-209 (Rev. 9), U.S. Department of Energy, Nevada Operations Office, Las Vegas, Nevada. CIC \#064994.

Note: Copies of documents with a CIC number may be obtained through the Coordination and Information Center, REECo, P.O. Box 98521, Las Vegas, NV 89193-8521. The documents are also available for public examination at 3084 South Highland Drive in Las Vegas. 


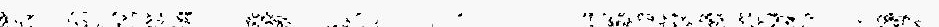




\title{
APPENDIX A \\ LOCATIONS CONSIDERED FOR THE TOWN DATA BASE
}

Table A-1 is an alphabetical list (by state, county, township, and location name) of the 604 locations for which we attempted to estimate exposure rate and time of arrival for at least one event. The 353 locations for which the estimates were considered usable for dose calculation (and which therefore have at least one record in the Town Data Base) are in bold.

Geographical positions are given by both Universal Transverse Mercator (UTM) coordinates and latitude-longitude. The UTM coordinates (Richardus and Adler, 1972) are given in a shortened form that was used in developing the Survey Meter Data Base because it could be determined with relative ease from 1:250,000 scale topographic maps produced by the U.S. Geological Survey. For example, the coordinates for Corn Creek in Clark County, Nevada (map NJ 11-12), are given as 11SPL4833, which is interpreted as follows:

\author{
11S is the Grid Zone designation \\ PL identifies the $100,000-\mathrm{m}$ square \\ 48 denotes $48,000 \mathrm{~m}$ east from the $\mathrm{SW}$ corner of square PL \\ 33 denotes $33,000 \mathrm{~m}$ north from the SW corner of square PL
}

UTM coordinates are not useful for calculating the distance between two locations because intermediate conversions are necessary and because a discontinuity in the UTM system occurs between Nevada and Utah. They were therefore converted to latitude and longitude in decimal format before being used in the estimation programs.

The control number is an identifier used in the estimation programs. 


\begin{tabular}{|c|c|c|c|c|c|c|}
\hline \multirow[t]{4}{*}{$\begin{array}{l}\text { ARIZONA } \\
\text { Apache }\end{array}$} & McNary & McNary & $12 \mathrm{SXN} 0570$ & 34.073 & 109.856 & 473 \\
\hline & Round Valley & Eagar & $12 S X N 5874$ & 34.111 & 109.290 & 477 \\
\hline & & Springerville & 12SXN5876 & 34.133 & 109.285 & 478 \\
\hline & St. Johns & St. Johns & $12 S X P 5019$ & 34.499 & 109.371 & 480 \\
\hline \multirow[t]{4}{*}{ Coconino } & Coconino & Flagstaff & 12SVP4195 & 35.193 & 111.653 & 484 \\
\hline & Kaibab & Fredonia & 12SUR6489 & 36.934 & 112.532 & 486 \\
\hline & Reservation & Page & 12SVR5885 & 36.907 & 111.477 & 488 \\
\hline & Williams & Williams & 12SUQ9201 & 35.243 & 112.192 & 490 \\
\hline \multirow[t]{26}{*}{ Mohave } & Kingman North & Catherine Ranger Sta. & 11SQK2301 & 35.224 & 114.555 & 693 \\
\hline & & Chloride & 11SQK5422 & 35.406 & 114.208 & 694 \\
\hline & & $\begin{array}{l}\text { Grasshopper Junction } \\
\text { Hackberry }\end{array}$ & $\begin{array}{l}\text { IISQK } 4820 \\
12 S T 05317\end{array}$ & $\begin{array}{l}35.389 \\
35.362\end{array}$ & $\begin{array}{l}114.275 \\
113.723\end{array}$ & 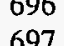 \\
\hline & & $\begin{array}{l}\text { Hackberry } \\
\text { Kingman }\end{array}$ & $\begin{array}{l}\text { 12SIQS317 } \\
\text { IISQJ6898 }\end{array}$ & $\begin{array}{l}35.362 \\
35.186\end{array}$ & $\begin{array}{l}113 . / 23 \\
114.062\end{array}$ & 493 \\
\hline & & Lake Mohave & $11 \mathrm{SQK} 1229$ & 35.479 & 114.668 & 699 \\
\hline & & Peach Springs & 12STQ8134 & 35.522 & 113.420 & 703 \\
\hline & & Truxton & 12STQ6829 & 35.474 & 113.562 & 706 \\
\hline & & Valentine & 12STQ5919 & 35.382 & 113.658 & 707 \\
\hline & & Walapai & 12STQ3915 & 35.341 & 113.877 & 708 \\
\hline & & Willow Beach & 1ISQKH/1 & 35.857 & 114.668 & 710 \\
\hline & Kingman South & Bullhead City & 11SQJ2192 & 35.144 & 114.579 & 692 \\
\hline & & Davis Dam & 11SQJ2295 & 35.170 & 114.567 & 695 \\
\hline & & Oatman & 11SQJ3979 & 35.022 & 114.385 & 702 \\
\hline & & Topock & 11SQJ3145 & 34.718 & 114.482 & 705 \\
\hline & & Warm Springs & 12STQ3816 & 35.350 & 113.888 & 709 \\
\hline & & Yucca & 11SQJ6163 & 34.873 & 114.150 & 712 \\
\hline & Mohave North & Beaver Dam & 12STR3988 & 36.899 & 113.934 & 690 \\
\hline & & Big Bend Ranch & 12STR3681 & 36.835 & 113.965 & 691 \\
\hline & & Colorado City & 12SUR2495 & 36.981 & 112.983 & 715 \\
\hline & & Hughes Ranch & IISQL6680 & 36.825 & 114.023 & 698 \\
\hline & & Kaibab Indian Reservation & 12SUR4585 & 36.895 & 112.745 & 927 \\
\hline & & Littlefield & 12STR4086 & 36.881 & 113.922 & 700 \\
\hline & & Moccasin & 12SUR4486 & 36.904 & 112.756 & 718 \\
\hline & & Mount Trumbull & 12STR9231 & 36.398 & 113.324 & 701 \\
\hline & & Short Creek & 12SUR2395 & 36.981 & 112.994 & 704 \\
\hline & & Wolf Hole & I2STR7370 & 36.745 & 113.548 & 711 \\
\hline \multirow[t]{4}{*}{ Navajo } & Little Colorado & Holbrook & 12SWP7663 & 34.903 & 110.173 & 501 \\
\hline & & Winslow & 12SWP2773 & 34.996 & 110.709 & 502 \\
\hline & Snowflake & Show Low & $12 \mathrm{SWN} 8990$ & 34.254 & 110.029 & 505 \\
\hline & & Snowflake & 12SWP8519 & 34.506 & 110.079 & 506 \\
\hline \multirow[t]{4}{*}{ Yuma } & Parker & Parker & 12SQH5082 & 34.150 & 114.288 & 509 \\
\hline & Somerton & Somerton & IISQG1408 & 32.596 & 114.708 & 511 \\
\hline & Yuma East & Yuma & 11SQG2222 & 32.725 & 114.623 & 514 \\
\hline & Yuma West & West Yuma & $11 S Q G 2022$ & 32.725 & 114.633 & 516 \\
\hline
\end{tabular}




\section{CALIFORNIA} Inyo

Bishop

Bishop

Laws

11 SLM7736

37.359

$118.394 \quad 519$

Death Valley

Death Valley Junction

11 SLM8140

37.396

118.350

738

Emigrant Springs Rang. Sta.

11SNL5217

36.293

116.426

727

Furnace Creek

36.493

117.228

729

Ryan

11SNL1333

36.439

116.860

732

Shoshone

Stove Pipe Wells

11 SNL3019

36.312

$116.671 \quad 753$

Tecopa

35.968

$116.284 \quad 754$

11SNK6581

36.610

$117.139 \quad 757$

Independence

Big Pine

Deep Springs

11SNK6967

35.842

$116.241 \quad 758$

Independence

$\begin{array}{llll}\text { 11SLM8514 } & 37.162 & 118.300 & 717 \\ 11 \text { SMM1336 } & 37.363 & 117.988 & 728\end{array}$

Lone Pine

Carago

Little Lake

Lone Pine

Olancha

South Haiwee

Kern

Arvin-Lamont

Arvin

Lamont

11 SLL9373

36.794

118.204

734

$\begin{array}{llll}11 \text { SML0820 } & 36.317 & 118.030 & 722\end{array}$

$\begin{array}{llll}11 S M K 1877 & 35.931 & 117.914 & 740\end{array}$

$\begin{array}{llll}11 \text { SML0551 } & 36.597 & 118.067 & 523\end{array}$

$\begin{array}{llll}11 S M L 0915 & 36.272 & 118.018 & 749\end{array}$

$\begin{array}{llll}11 S M K 1499 & 36.129 & 117.961 & 756\end{array}$

Kem

Bakersfield

Bakersfield

Delano

Delano

$\begin{array}{llll}11 \text { SLJ3397 } & 35.199 & 118.839 & 526\end{array}$

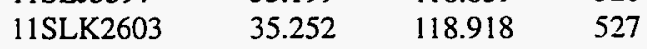

East Kern

Boron

Cantil

China Lake

Inyokern

Johannesburg

Mojave

Randsburg

$\begin{array}{llll}11 S L K 1715 & 35.358 & 119.019 & 529\end{array}$

$\begin{array}{llll}11 S K K 9761 & 35.769 & 119.251 & 535\end{array}$

$\begin{array}{llll}11 S M J 4173 & 34.995 & 117.651 & 719\end{array}$

$\begin{array}{llll}11 S M K 1207 & 35.299 & 117.973 & 721\end{array}$

$\begin{array}{llll}11 S M K 4145 & 35.644 & 117.657 & 724\end{array}$

$\begin{array}{llll}11 S M K 2745 & 35.643 & 117.811 & 735\end{array}$

$\begin{array}{llll}11 S M K 4314 & 35.364 & 117.632 & 736\end{array}$

$\begin{array}{llll}11 S L J 9379 & 35.045 & 118.178 & 537\end{array}$

$\begin{array}{llll}11 S L M 9379 & 35.045 & 118.178 & 537 \\ \text { IISMK4114 } & 35.364 & 117.654 & 750\end{array}$

McFarland-Delano Rur. McFarland

$\begin{array}{llll}11 S K K 9850 & 35.670 & 119.237 & 542\end{array}$

Ridgecrest Ridgecrest

$\begin{array}{llll}11 S M K 3942 & 35.617 & 117.679 & 538\end{array}$

Shafter Shafter

Tehachapi

Tehachapi

11 SKK9330

35.489

119.287

546

11 SLJ6887

35.114

118.453

548

Wasco

Wasco

11SKK8841

35.587

119.345

550

Westside

Ford City

Maricopa

South Taft

Taft

11SKJ7892

35.143

35.054

$119.442 \quad 552$

11 SKJ7689

35.116

119.406

11 SKJ7692

35.143

119.463

553

Taft Heights

11 SKJ7490

35.124

119.464

554

Susanville

10TFV9976

40.408

119.485

556

Lassen

Susanville

Westwood

10TFV7066

40.324

120.660

562

Westwood

Benton

Chalfant

11SLM7086

37.809

121.004

564

Mono South

1 ISLM7954

37.522

$118.482 \quad 716$

$118.374 \quad 723$ 


\begin{tabular}{|c|c|c|c|c|c|c|}
\hline & & Crest View & 11 SLM2580 & 37.747 & 118.991 & 725 \\
\hline & & Oasis & 11SMM2049 & 37.481 & 117.910 & 748 \\
\hline & & Tom's Place & 11SLM5258 & 37.554 & 118.681 & 759 \\
\hline Riverside & Alvord & Home Gardens & 11SMH5248 & 33.878 & 117.520 & 570 \\
\hline & Cathedral Cty-Palm Dsrt & Cathedral City & 11 SNH4937 & 33.779 & 116.464 & 572 \\
\hline & & Palm Desert & 11SNH5730 & 33.721 & 116.387 & 573 \\
\hline & Coachella Valley & Coachella & 11 SNH7327 & 33.677 & 116.217 & 576 \\
\hline & & Indio & 11SNH7131 & 33.720 & 116.214 & 577 \\
\hline & Corona & Corona & 11 SMH5047 & 33.859 & 117.545 & 579 \\
\hline & Desert Hot Springs & Desert Hot Springs & 11 SNH4658 & 33.961 & 116.500 & 581 \\
\hline & Edgemont-Sunnymead & Edgemont & 11SMH7454 & 33.920 & 117.277 & 583 \\
\hline & & Sunnymead & 11SMH7855 & 33.940 & 117.242 & 584 \\
\hline & Elsinore Valley & Elsinore & 11SMH7026 & 33.668 & 117.326 & 586 \\
\hline & & Lakeland Village & 11SMH6822 & 33.638 & 117.343 & 587 \\
\hline & Hemet-San Jacinto & Hemet & 11SNH0434 & 33.747 & 116.971 & 589 \\
\hline & & Hemet East & 11SNH0534 & 33.747 & 116.971 & 590 \\
\hline & & San Jacinto & 11SNH0438 & 33.783 & 116.957 & 591 \\
\hline & Jurupa & Glen Avon Heights & 11SMH5365 & 34.011 & 117.483 & 595 \\
\hline & & Mira Loma & 11SMH5162 & 33.994 & 117.535 & 596 \\
\hline & Norco & Norco & 11SMH5054 & 33.560 & 117.330 & 600 \\
\hline & Palm Springs & Palm Springs & 11SNH4343 & 33.830 & 116.544 & 602 \\
\hline & Palo Verde & Blythe & 11SQH2321 & 33.610 & 114.595 & 604 \\
\hline & Perris Valley & Perris & 11SMH7938 & 33.782 & 117.227 & 606 \\
\hline & Riverside & Riverside & 11SMH6055 & 33.953 & 117.395 & 608 \\
\hline & San Gorgonio Pass & Banning & 11SNH0954 & 33.925 & 116.875 & 610 \\
\hline & & Beaumont & 11SNH0454 & 33.929 & 116.976 & 611 \\
\hline & & Cabazon & 11SNH1953 & 33.917 & 116.786 & 612 \\
\hline San Bernardino & Arrowhead & Crestline & 11SMH7388 & 34.241 & 117.284 & 619 \\
\hline & Big Bear & Big Bear Lake & 11SNH0788 & 34.243 & 116.910 & 623 \\
\hline & Chino & Chino & 11SMH3664 & 34.012 & 117.688 & 625 \\
\hline & Colton & Colton & 11 SMH6870 & 34.073 & 117.312 & 627 \\
\hline & Fontana & Fontana & 11SMH6072 & 34.092 & 117.434 & 632 \\
\hline & Mojave Valley & Barstow & 11SMJ9860 & 34.879 & 117.027 & 621 \\
\hline & & Daggett & $11 S N J 1157$ & 34.852 & 116.885 & 726 \\
\hline & & Four Corners & 11 SMJ5172 & 34.986 & 117.542 & 731 \\
\hline & & Hinkley & 11SMJ8266 & 34.933 & 117.202 & 733 \\
\hline & & Manix & 11SNJ3771 & $34.8 / 0$ & 116.600 & $\begin{array}{l}039 \\
743\end{array}$ \\
\hline
\end{tabular}




\begin{tabular}{|c|c|c|c|c|c|c|}
\hline & & Yermo & 11 SNJ1562 & 34.897 & 116.841 & 762 \\
\hline & Montclair & Montclair & $11 \mathrm{SMH} 3670$ & 34.060 & 117.410 & 641 \\
\hline & Needles & Essex & 11 SPJ6145 & 34.731 & 115.246 & 730 \\
\hline & & Needles & 11SQJ1857 & 34.829 & 114.621 & 644 \\
\hline & Newberry-Baker & Baker & 11 SNK8402 & 35.254 & 116.082 & 714 \\
\hline & & Kelso & 11 SPJ2375 & 35.007 & 115.657 & 737 \\
\hline & & Ludlow & $11 S N J 7743$ & 34.723 & 116.164 & 742 \\
\hline & & Mountain Pass & $11 \mathrm{SPK} 3325$ & 35.456 & 115.539 & 745 \\
\hline & & Newberry & $11 S N J 2954$ & 34.825 & 116.688 & 747 \\
\hline & & Wheaton Springs & 11 SPK 3925 & 35.456 & 115.473 & 761 \\
\hline & & Zzyzx Springs & 11 SNJ8189 & 35.137 & 116.116 & 763 \\
\hline & Ontario & Ontario & 11 SMH4070 & 34.063 & 117.650 & 647 \\
\hline & Red Mountain-Trona & Camp Irwin & 11SNK2802 & 35.258 & 116.697 & 720 \\
\hline & & Red Mountain & $11 \mathrm{SMK} 4412$ & 35.346 & 117.621 & 751 \\
\hline & & Silver Lake & 11SNK8014 & 35.363 & 116.124 & 755 \\
\hline & & Trona & 11SMK6757 & 35.753 & 117.370 & 653 \\
\hline & Redlands & Redlands & 11SMH8367 & 34.061 & 117.181 & 650 \\
\hline & Rialto & Rialto & 11SMH6674 & 34.106 & 117.369 & 655 \\
\hline & San Bernardino & San Bernardino & 11SMH7576 & 34.121 & 117.276 & 658 \\
\hline & Morongo Valley & Amboy & 11 SPJ 1525 & 34.557 & 115.751 & 713 \\
\hline & Upland & Upland & $11 \mathrm{SMH} 4073$ & 34.097 & 117.647 & 664 \\
\hline NEVADA & & & & & & \\
\hline Churchill & New River & Fallon & I1SLP4771 & 39.472 & 118.784 & 5 \\
\hline Clark & Bunkerville & Bunkerville & 11SQL5673 & 36.765 & 114.137 & 789 \\
\hline & Goodsprings & Goodsprings & $11 S P K 4266$ & 35.825 & 115.433 & 822 \\
\hline & & Pop's Oasis & 11 SPK5261 & 35.778 & 115.323 & 870 \\
\hline & & State Line & $11 S P K 4642$ & 35.608 & 115.393 & 894 \\
\hline & Henderson & Henderson & $11 S P K 8289$ & 36.025 & 114.985 & 10 \\
\hline & Las Vegas & Apex & 11SPL8420 & 36.304 & 114.956 & 768 \\
\hline & & Arden & 11SPK5987 & 36.011 & 115.241 & 2005 \\
\hline & & Blue Diamond & $11 \mathrm{SPK} 4490$ & 36.041 & 115.407 & 781 \\
\hline & & Bonanza Boy Scout Camp & 11SPL1918 & 36.297 & 115.680 & 783 \\
\hline & & Cactus Springs & 11 SPL1448 & 36.568 & 115.731 & 791 \\
\hline & & Charleston Lodge & IISPL2114 & 36.260 & 115.658 & 795 \\
\hline & & Corn Creek & 11SPL4833 & 36.428 & 115.354 & 801 \\
\hline & & Desert Game Refuge & 11SPL4734 & 36.437 & 115.365 & 957 \\
\hline & & Dry Lake & 1ISPL9336 & 36.447 & 114.852 & 810 \\
\hline & & Garnet & 11SPL9129 & 36.384 & 114.876 & 816 \\
\hline & & Indian Springs & 11SPL2048 & 36.567 & 115.664 & 830 \\
\hline & & Las Vegas & & & & \\
\hline & & $\begin{array}{l}\text { (Junct US 91+US93) } \\
\text { Mountain Springs }\end{array}$ & $\begin{array}{l}\text { 11SPL6504 } \\
\text { 11SPK3485 }\end{array}$ & $\begin{array}{l}36.164 \\
35.997\end{array}$ & $\begin{array}{l}115.171 \\
115.518\end{array}$ & $\begin{array}{r}12 \\
2004\end{array}$ \\
\hline & & Nellis Air Force Base & $11 S P L 7612$ & 36.234 & 115.047 & 858 \\
\hline
\end{tabular}




\begin{tabular}{|c|c|c|c|c|c|c|}
\hline & \multirow{3}{*}{$\begin{array}{l}\text { North Las Vegas } \\
\text { Pittman } \\
\text { Whitney }\end{array}$} & \multirow{3}{*}{$\begin{array}{l}\text { 11SPL7008 } \\
\text { 11SPK7992 } \\
\text { 11SPK7695 }\end{array}$} & \multirow{3}{*}{$\begin{array}{l}36.199 \\
36.053 \\
36.081\end{array}$} & \multirow{3}{*}{$\begin{array}{l}115.114 \\
115.018 \\
115.050\end{array}$} & \multirow{3}{*}{$\begin{array}{r}13 \\
868 \\
910\end{array}$} \\
\hline & & & & & & \\
\hline & & & & & & \\
\hline & Logandale & Logandale & 11SQL2553 & 36.593 & 114.490 & 845 \\
\hline & \multirow[t]{2}{*}{ Mesquite } & Mesquite & 11SQL6177 & 36.800 & 114.080 & 851 \\
\hline & & Riverside & 11SQL4769 & 36.732 & 114.239 & 876 \\
\hline & \multirow[t]{7}{*}{ Moapa } & Crystal & 11SQL0041 & 36.490 & 114.772 & 804 \\
\hline & & Farrier & 11SQL0979 & 36.831 & 114.662 & 958 \\
\hline & & Glendale & 11SQL1760 & 36.658 & 114.577 & 819 \\
\hline & & Moapa & 11SQL1261 & 36.668 & 114.633 & 854 \\
\hline & & Moapa Indian Reservation & 11SQL0961 & 36.669 & 114.666 & 855 \\
\hline & & Searls Ranch & 11SQL1659 & 36.649 & 114.589 & 887 \\
\hline & & Warm Springs Ranch & 11SQL0465 & 36.706 & 114.721 & 907 \\
\hline & \multirow[t]{4}{*}{ Nelson } & Boulder City & 11SPK9683 & 35.969 & 114.831 & 18 \\
\hline & & Hoover Dam & 11SQK0487 & 36.003 & 114.742 & 827 \\
\hline & & Lake Mead Base & 11SQK0189 & 36.022 & 114.774 & 836 \\
\hline & & Nelson & 11SPK9753 & 35.698 & 114.828 & 859 \\
\hline & \multirow[t]{2}{*}{ Overton } & Overton & 11SQL2847 & 36.538 & 114.458 & 862 \\
\hline & & Overton Beach & 11SQL3736 & 36.437 & 114.361 & 2006 \\
\hline & Searchlight & Searchlight & 11SPK8926 & 35.456 & 114.922 & 886 \\
\hline Douglas & East Fork & Gardnerville-Minden & 11SKP6214 & 38.939 & 119.751 & 41 \\
\hline \multirow[t]{3}{*}{ Elko } & \multirow[t]{2}{*}{ Township 5} & Carlin & 11TNR7507 & 40.707 & 116.118 & 30 \\
\hline & & Elko & IITPR0420 & 40.821 & 115.772 & 31 \\
\hline & Township 6 & Wells & 11TPR7153 & 41.107 & 114.969 & 33 \\
\hline \multirow[t]{9}{*}{ Esmeralda } & Dist. 1, Goldfield & Goldfield & 11SMM8073 & 37.701 & 117.232 & 820 \\
\hline & \multirow[t]{2}{*}{ Dist. 2, Silver Peak } & Nivloc Mine & 11SMM3574 & 37.708 & 117.743 & 860 \\
\hline & & Silver Peak & 1SSMM4578 & 37.744 & 117.629 & 891 \\
\hline & Dist. 3, Fishlake & Dyer & 11SMM0571 & 37.678 & 118.082 & 932 \\
\hline & \multirow[t]{2}{*}{ Dist. 4, Lida } & Lida & 11SMM5645 & 37.448 & 117.503 & 841 \\
\hline & & Lida Junction & 11SMM8450 & 37.494 & 117.186 & 842 \\
\hline & Dist. 5, Gold Point & Gold Point & 11 SMM6834 & 37.349 & 117.366 & 821 \\
\hline & \multirow[t]{2}{*}{ Dist. 6, Millers } & Blair Junction & 11 SMN3208 & 38.014 & 117.780 & 2013 \\
\hline & & Coaldale & $11 S M N 2308$ & 38.013 & 117.882 & 799 \\
\hline \multirow[t]{3}{*}{ Eureka } & \multirow[t]{3}{*}{ Eureka } & Eureka & 11SNP9074 & 39.508 & 115.958 & 792 \\
\hline & & Fish Creek Ranch & 1ISNP9146 & 39.255 & 115.951 & 814 \\
\hline & & Ruby Hill Mine & 11SNP8773 & 39.499 & 115.993 & 882 \\
\hline \multirow[t]{3}{*}{ Humboldt } & Gold Run & Gold Run & 11TMR 1856 & 41.148 & 117.983 & 226 \\
\hline & McDermitt & McDermitt & 11TMS4149 & 41.988 & 117.718 & 250 \\
\hline & Paradise Valley & Paradise Valley & 11TMR5593 & 41.484 & 117.545 & 382 \\
\hline
\end{tabular}




\begin{tabular}{|c|c|c|c|c|c|c|}
\hline & Union & Winnemucca & 11TMR3935 & 40.961 & 117.730 & 53 \\
\hline \multirow[t]{2}{*}{ Lander } & Austin & Austin & 11SMP9471 & 39.485 & 117.075 & 772 \\
\hline & & Laboard Ranch & 11SMP9756 & 39.350 & 117.040 & 835 \\
\hline \multirow[t]{47}{*}{ Lincoln } & Alamo & Alamo & 11SPM6336 & 37.353 & 115.165 & 767 \\
\hline & & Ash Springs & 11SPM6047 & 37.453 & 115.196 & 770 \\
\hline & & Buckhorn Ranch & 11SPM6527 & 37.272 & 115.144 & 788 \\
\hline & & Crystal Springs & 11SPM5655 & 37.526 & 115.240 & 846 \\
\hline & & Dodge Constr. Camp & 11SPM1465 & 37.622 & 115.713 & 808 \\
\hline & & Groom Mine & 11SPM1033 & 37.334 & 115.763 & 823 \\
\hline & & Hiko & 11SPM5762 & 37.589 & 115.227 & 825 \\
\hline & & Lincoln Mine & 11SPM2166 & 37.630 & 115.634 & 843 \\
\hline & & Southpaw Mine & 11SPM4370 & 37.663 & 115.384 & 892 \\
\hline & & Tempiute & 11SPM2068 & 37.648 & 115.645 & 2010 \\
\hline & & Watertown & 11SPM0928 & 37.289 & 115.775 & 908 \\
\hline & & Whipple Ranch & 11SPM5866 & 37.624 & 115.215 & 909 \\
\hline & Caliente & Acoma & 11SQM5059 & 37.541 & 114.176 & 765 \\
\hline & & Ballow Ranch & 11SQM1451 & 37.478 & 114.585 & 2015 \\
\hline & & Barclay & 11SQM4355 & 37.507 & 114.256 & 775 \\
\hline & & Boyd & IISQM1545 & 37.424 & 114.575 & 786 \\
\hline & & Butler Ranch & 11 SPL7993 & 36.963 & 114.994 & 790 \\
\hline & & Caliente & 11SQM1965 & 37.603 & 114.524 & 60 \\
\hline & & Carp & 11SQM2310 & 37.107 & 114.496 & 793 \\
\hline & & Cloud & 11SQM2515 & 37.151 & 114.472 & 798 \\
\hline & & Crestline & 11SQM5372 & 37.657 & 114.137 & 803 \\
\hline & & Elgin & 11sQM1836 & 37.342 & 114.544 & 773 \\
\hline & & Etna & 11SQM1459 & 37.550 & 114.583 & 785 \\
\hline & & Galt & 11SQL1398 & 37.001 & 114.611 & 815 \\
\hline & & Hoya & 11SQL0991 & 36.939 & 114.658 & 828 \\
\hline & & Kyle & 11SQM2332 & 37.305 & 114.489 & 834 \\
\hline & & Leith & $11 \mathrm{SQM} 2526$ & 37.250 & 114.468 & 840 \\
\hline & & $\operatorname{Rox}$ & 11SQL0884 & 36.876 & 114.671 & 881 \\
\hline & & Stine & 11SQM1452 & 37.487 & 114.585 & 896 \\
\hline & & Vigo & 11SQM1705 & 37.063 & 114.564 & 904 \\
\hline & Panaca & Panaca & $11 \mathrm{SQM} 3085$ & 37.780 & 114.394 & 865 \\
\hline & Pioche & Atlanta & 11SQN3361 & 38.464 & 114.335 & 77 \\
\hline & & Bristol Silver Mine & 11SQN0917 & 38.074 & 114.623 & 78 \\
\hline & & Caselton Mine & 11SQM2199 & 37.909 & 114.491 & 79 \\
\hline & & Cole \& Dolan Ranch & $11 \mathrm{SQN} 2745$ & 38.321 & 114.409 & 80 \\
\hline & & Delmue & $11 \mathrm{SQM} 3694$ & 37.860 & 114.323 & 80 \\
\hline & & Donahue Ranch & $11 S Q N 4641$ & 38.280 & 114.193 & \\
\hline & & Geyser Maintenance Sta. & 11SQN0679 & 38.633 & 114.639 & 8 \\
\hline & & Geyser Ranch & 11SQN0683 & 38.669 & 114.637 & 818 \\
\hline & & Hollinger's Ranch & 11SQN4918 & 38.073 & 114.167 & 82 \\
\hline & & Pioche & $11 \mathrm{SQN} 2401$ & 37.926 & 114.457 & 86 \\
\hline & & Pony Springs & 11SQN0943 & 38.308 & 114.615 & 8 \\
\hline & & Rose Valley & 11SQN4202 & 37.930 & 114.252 & 87 \\
\hline & & Seven L. Ranch & $11 \mathrm{SQN} 4815$ & 38.046 & 114.179 & 88 \\
\hline & & Steward R. Ranch & 11SQN0135 & 38.238 & 114.709 & 85 \\
\hline & & Urretias Ranch & 11SPN9179 & 38.636 & 114.811 & 90 \\
\hline & & Ursine & 11SQN4407 & 37.975 & 114.227 & 90 \\
\hline \multirow[t]{3}{*}{ Lyon } & Fernley & Fernley & 11SLP0586 & 39.598 & 119.276 & 59 \\
\hline & Mason Valley & Weed Heights & 11SLP0817 & 38.978 & 119.222 & 67 \\
\hline & & Yerington & 11 SLP1317 & 38.979 & 119.164 & 6 \\
\hline
\end{tabular}




\begin{tabular}{|c|c|c|c|c|c|c|}
\hline \multirow[t]{6}{*}{ Mineral } & Hawthorne & $\begin{array}{l}\text { Babbitt } \\
\text { Hawthorne }\end{array}$ & $\begin{array}{l}\text { 11SLN5666 } \\
11 \text { SLN5765 }\end{array}$ & $\begin{array}{l}38.528 \\
38.519\end{array}$ & $\begin{array}{l}118.657 \\
118.646\end{array}$ & $\begin{array}{l}73 \\
74\end{array}$ \\
\hline & Luning & Luning & 11SLN9762 & 38.497 & 118.186 & 847 \\
\hline & Mina & Basalt & 11SLN8807 & 38.001 & 118.281 & 777 \\
\hline & & Mina & 11SMN0349 & 38.381 & 118.116 & 853 \\
\hline & & Montgomery Pass & 11SLN8303 & 37.964 & 118.337 & 744 \\
\hline & Schurz & Schurz & 11 SLP4313 & 38.949 & 118.817 & 885 \\
\hline \multirow[t]{42}{*}{ Nye } & Beatty & $\begin{array}{l}\text { Amargosa Hot Springs } \\
\text { (Hicks) }\end{array}$ & 11SNL2195 & 36.998 & 116.769 & 760 \\
\hline & & Ash Meadows & 11SNL6324 & 36.356 & 116.303 & 769 \\
\hline & & Beatty & 11SNL2184 & 36.899 & 116.769 & 778 \\
\hline & & Carrara & 11SNL2672 & 36.790 & 116.714 & 2007 \\
\hline & & Desert Rock & 11SNL8652 & 36.606 & 116.044 & 807 \\
\hline & & Johnnie & 11SNL8331 & 36.417 & 116.079 & 832 \\
\hline & & Lathrop Wells & 11SNL5455 & 36.636 & 116.401 & 838 \\
\hline & & Mercury & 11SNL9158 & 36.660 & 115.987 & 850 \\
\hline & & Pahrump & 11SNL9107 & 36.200 & 115.993 & 863 \\
\hline & & Pahrump Mining Co. & 11SNL8535 & 36.453 & 116.057 & 864 \\
\hline & & Rhyolite & 11SNL1584 & 36.899 & 116.837 & 877 \\
\hline & & Sarcobatus & IISMM9923 & 37.250 & 117.016 & 884 \\
\hline & & Scotty's Junction & 11SMM9627 & 37.286 & 117.050 & 954 \\
\hline & & Springdale & 11SNL2298 & 37.025 & 116.758 & 893 \\
\hline & Gabbs & Gabbs & 11SMP2102 & 38.860 & 117.916 & 83 \\
\hline & Manhattan & Belmont & 11 SNN1171 & 38.584 & 116.879 & 780 \\
\hline & & Manhattan & 11SMN9465 & 38.530 & 117.074 & 849 \\
\hline & & Parmon's Ranch & $11 \mathrm{SNN} 0460$ & 38.485 & 116.959 & 866 \\
\hline & Round Mountain & Bond Ranch & 11SMP8927 & 39.089 & 117.132 & 784 \\
\hline & & Millett & 11 SMP8519 & 39.017 & 117.179 & 852 \\
\hline & & Potts & 11 SNP2724 & 39.062 & 116.693 & 871 \\
\hline & & Round Mountain & 11SMN9484 & 38.701 & 117.074 & 880 \\
\hline & Tonopah & A \& B Mine & 11SNN4634 & 38.250 & 116.480 & 764 \\
\hline & & Adam's Ranch & 11SPN6980 & 38.649 & 115.063 & 766 \\
\hline & & Adaven (Sharps) & $11 \mathrm{SPN} 2321$ & 38.125 & 115.602 & 889 \\
\hline & & Bardoli Ranch & 11 SPN2234 & 38.243 & 115.611 & 776 \\
\hline & & Belew Ranch & 11 SPN2321 & 38.125 & 115.602 & 779 \\
\hline & & Blue Eagle School & 11 SPN2765 & 38.521 & 115.548 & 782 \\
\hline & & Clark's Station & 11SNN3322 & 38.142 & 116.629 & 797 \\
\hline & & Currant & 11SPN3389 & 38.737 & 115.475 & 805 \\
\hline & & Duckwater & $11 S P P 1110$ & 38.929 & 115.725 & 811 \\
\hline & & Fallini Ranch & 11SNN7228 & 38.194 & 116.183 & 813 \\
\hline & & Indian Creek Ranch & 11SPP1119 & 39.010 & 115.723 & 829 \\
\hline & & Ione & 11SMP5011 & 38.943 & 117.582 & 831 \\
\hline & & Johnnies Water & 11SNM8143 & 37.427 & 116.090 & 2011 \\
\hline & & Lockes & 11SPN0767 & 38.542 & 115.777 & 844 \\
\hline & & M \& M Mine & IISNN4634 & 38.250 & 116.480 & 848 \\
\hline & & Mellan & 11SNM3673 & 37.700 & 116.597 & 2008 \\
\hline & & Moon River Ranch & IISPN5948 & 38.363 & 115.185 & 856 \\
\hline & & Nyala Ranch & 1ISPN1234 & 38.244 & 115.725 & 861 \\
\hline & & Rattlesnake Maint. Sta. & 11SNN7357 & 38.455 & 116.169 & 873 \\
\hline & & Reed & 11SNM7679 & 37.752 & 116.142 & 874 \\
\hline
\end{tabular}




\begin{tabular}{|c|c|c|c|c|c|c|}
\hline & & Reveille Mill & 11SNN5606 & 37.997 & 116.367 & 875 \\
\hline & & Standard (Goldreed) & 11SNM6256 & 37.546 & 116.303 & 955 \\
\hline & & Stone Cabin Ranch & 11 SNN3228 & 38.196 & 116.640 & 897 \\
\hline & & Sunnyside & 11SPN7354 & 38.414 & 115.024 & 898 \\
\hline & & Tonopah & 11SMN8012 & 38.052 & 117.233 & 87 \\
\hline & & Tonopah Airport & 11SMN9311 & 38.044 & 117.085 & 900 \\
\hline & & Tybo & 11SNN5247 & 38.367 & 116.410 & 2009 \\
\hline & & Uhalde Ranch & 11SPN2519 & 38.107 & 115.579 & 901 \\
\hline & & Walch Pine Creek Ranch & 11SPN1912 & 38.045 & 115.649 & 905 \\
\hline & & Warm Springs & 11 SNN5527 & 38.186 & 116.377 & 906 \\
\hline $\begin{array}{l}\text { Ormsby } \\
\text { (Carson City) }\end{array}$ & Carson & Carson City & 11SKP6139 & 39.164 & 119.772 & 90 \\
\hline Pershing & Lake & Lovelock & 11TLQ7448 & 40.170 & 118.485 & 94 \\
\hline Storey & Virginia City & Virginia City & $11 S K P 7255$ & 39.311 & 119.650 & 633 \\
\hline \multirow[t]{3}{*}{ Washoe } & Reno & Reno & 11 SKP5980 & 39.533 & 119.809 & 102 \\
\hline & Sparks & Sparks & $11 S K P 6380$ & 39.534 & 119.763 & 105 \\
\hline & Wadsworth & Wadsworth & 11 SLP0489 & 39.625 & I19.289 & 959 \\
\hline \multirow[t]{23}{*}{ White Pine } & \multirow[t]{7}{*}{ Township 1, Ely } & East Ely & 11 SPP8446 & 39.241 & 114.873 & 110 \\
\hline & & Ely & 11 SPP8246 & 39.241 & 114.896 & 111 \\
\hline & & Kimberly & 11SPP7147 & 39.252 & 115.024 & 833 \\
\hline & & Lane City & 11SPP7848 & 39.260 & 114.942 & 837 \\
\hline & & McGill & 11 SPP9163 & 39.392 & 114.787 & 112 \\
\hline & & Ruth & 11 SPP7449 & 39.270 & 114.988 & 883 \\
\hline & & Warm Springs North & 11SPP8891 & 39.645 & 114.814 & 956 \\
\hline & Township 2, Hamilton & Eldorado & $11 S P P 0159$ & 39.372 & 115.833 & 739 \\
\hline & \multirow[t]{2}{*}{ Township 3, Preston } & Cove & $11 S P P 6113$ & 38.948 & 115.147 & 802 \\
\hline & & Preston & 11SPP6808 & 38.902 & 115.068 & 872 \\
\hline & \multirow[t]{2}{*}{ Township 4, Lund } & Gubler Ranch & 11SPN7393 & 38.766 & 115.014 & 824 \\
\hline & & Lund & $11 S P P 7302$ & 38.847 & 115.012 & 103 \\
\hline & Township 5, Cherry Crk & Cherry Creek & 11SPQ8118 & 39.890 & 114.888 & 796 \\
\hline & Township 6, Muncy & Lages Station & 11TQQ0338 & 40.080 & 114.600 & 45 \\
\hline & \multirow{8}{*}{ Township 7, Osceola } & Baker & 11SQP4922 & 39.009 & 114.130 & 774 \\
\hline & & D-X Ranch & 11SQP2539 & 39.168 & 114.401 & 812 \\
\hline & & $\begin{array}{l}\text { Eldridge Ranch } \\
\text { (Mt.Wheeler Inn) }\end{array}$ & 11SQP3136 & 39.140 & 114.333 & 746 \\
\hline & & Lehman Caves & 11SQP3821 & 39.003 & 114.257 & 839 \\
\hline & & Mounts Ranch & $11 \mathrm{SQP} 2128$ & 39.070 & 114.451 & 857 \\
\hline & & Rogers Ranch & $11 \mathrm{SQP} 1854$ & 39.305 & 114.477 & 878 \\
\hline & & Shoshone & 11SQP2502 & 38.835 & 114.413 & 890 \\
\hline & & Swalow Ranch & $11 S Q P 2311$ & 38.917 & 114.433 & 899 \\
\hline & Township 8, Neward & $\begin{array}{l}\text { Eldridge Ranch } \\
\text { (N of Eureka) }\end{array}$ & 11 SPP0588 & 39632 & 115.782 & 741 \\
\hline & & & & & & \\
\hline \multirow[t]{2}{*}{ Beaver } & \multirow[t]{2}{*}{ Beaver } & Adamsville & 12SUT4335 & 38.246 & 112.799 & 911 \\
\hline & & Beaver & 12SUT5637 & 38.266 & 112.651 & 122 \\
\hline
\end{tabular}




\begin{tabular}{|c|c|c|c|c|c|c|}
\hline & & $\begin{array}{l}\text { Greenville } \\
\text { Manderfield }\end{array}$ & $\begin{array}{l}\text { 12SUT5035 } \\
\text { 12SUT5746 }\end{array}$ & $\begin{array}{l}38.247 \\
38.348\end{array}$ & $\begin{array}{l}112.719 \\
112.642\end{array}$ & $\begin{array}{l}923 \\
931\end{array}$ \\
\hline & Milford-Minersville & Milford & 12SUT2451 & 38.387 & 113.020 & 124 \\
\hline & & Minersville & 12SUT3231 & 38.208 & 112.924 & 25 \\
\hline Boxelder & Bear River & Bear River City & 12TVB0607 & 41.606 & 112.134 & 128 \\
\hline & & Bothwell & 12TUB9519 & 41.713 & 112.268 & 129 \\
\hline & & Corinne & 12TVB0700 & 41.543 & 112.120 & 130 \\
\hline & & Elwood & 12TVB0516 & 41.687 & 112.147 & 131 \\
\hline & & Fielding & 12TVB0729 & 41.804 & 112.125 & 132 \\
\hline & & Garland & 12TVB0321 & 41.732 & 112.172 & 13 \\
\hline & & Tremonton & 12TVB0318 & 41.705 & 112.171 & 13 \\
\hline & Benchiand & Deweyville & 12TVB0918 & 41.705 & 112.099 & \\
\hline & & Honeyville & 12TVB1010 & 41.634 & 112.086 & 137 \\
\hline & Brigham City & Brigham City & 12TVA1596 & 41.508 & 112.024 & 13 \\
\hline & & Mantua & 12TVA2194 & 41.491 & 111.952 & 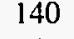 \\
\hline & & Perry & 12TVA1391 & 41.463 & 112.047 & 14 \\
\hline & & Willard & 12TVA1384 & 41.400 & 112.046 & 14 \\
\hline & Howell-Snowville & Howell & 12TUB8028 & 41.792 & 112.450 & \\
\hline & & Plymouth & 12TVB 0537 & 41.876 & 112.150 & \\
\hline & & Portage & 12TUB9748 & 41.974 & 112.249 & 1 \\
\hline & & Snowville & 12TUB5847 & 41.959 & 112.719 & \\
\hline & West Box Elder & Yost & 12ТTB8948 & 41.953 & 113.551 & 14 \\
\hline Cache & Hyrum & Hyrum & 12TVB2909 & 41.626 & 111.858 & 152 \\
\hline & & Nibley & 12TVB3014 & 41.672 & 111.846 & 15 \\
\hline & & Paradise & 12TVB3002 & 41.563 & 111.845 & 10 \\
\hline & Lewiston & Clarkston & 12TVB 1241 & 41.913 & 112.067 & \\
\hline & & Cornish & 12TVB2147 & 41.968 & 111.959 & \\
\hline & & Lewiston & 12TVB2947 & 41.969 & 111.862 & l. \\
\hline & & Richmond & 12TVB3341 & 41.915 & 111.813 & \\
\hline & & Trenton & 12TVB2241 & 41.914 & 111.946 & \\
\hline & Logan & Logan & 12TVB3121 & 41.735 & 111.835 & 02 \\
\hline & & Millville & 12TVB3115 & 41.681 & 111.835 & It \\
\hline & & North Logan & 12TVB3224 & 41.762 & 111.824 & \\
\hline & & Providence & 12TVB3217 & 41.699 & 111.823 & 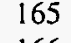 \\
\hline & & River Heights & 12TVB3119 & 41.717 & 111.835 & \\
\hline & Smithfield & Amalga & 12TVB2634 & 41.851 & 111.897 & \\
\hline & & Hyde Park & 12TVB3228 & 41.798 & 111.824 & \\
\hline & & Newton & 12TVB1834 & 41.851 & 111.993 & \\
\hline & & Smithfield & 12TVB3132 & 41.834 & 111.837 & \\
\hline & Wellsville & Mendon & 12TVB1818 & 41.706 & 111.991 & \\
\hline & & Wellsville & 12TVB2210 & 41.635 & 111.942 & \\
\hline Carbon & Helper & Castle Gate & 12SWU1198 & 39.729 & 110.877 & 177 \\
\hline & & Helper & 12SWU1292 & 39.675 & 110.865 & 17 \\
\hline & Price & Hiawatha & 12SVU9970 & 39.476 & 111.017 & 180 \\
\hline & & Price & 12SWU1683 & 39.593 & 110.819 & \\
\hline
\end{tabular}




\begin{tabular}{|c|c|c|c|c|c|c|}
\hline & & Wellington & 12SWU2377 & 39.539 & 110.738 & 182 \\
\hline & Scofield & Scofield & 12SVU8697 & 39.720 & 111.169 & 184 \\
\hline & Sunnyside & Dragerton & 12SWU5077 & 39.538 & 110.423 & 186 \\
\hline & & Sunnyside & 12SWU5278 & 39.547 & 110.400 & 187 \\
\hline Daggett & Daggett & Manila & 12TXA0737 & 40.974 & 109.734 & 190 \\
\hline Davis & North Davis & Clearfield & 12TVA1551 & 41.103 & 112.018 & 193 \\
\hline & & Clinton & 12TVA1054 & 41.129 & 112.078 & 194 \\
\hline & & East Layton & 12TVA2348 & 41.076 & 111.922 & 195 \\
\hline & & Fruit Heights & 12TVA2441 & 41.014 & 111.909 & 196 \\
\hline & & Kaysville & 12TVA2143 & 41.031 & 111.945 & 197 \\
\hline & & Layton & 12TVA 1946 & 41.058 & 111.969 & 198 \\
\hline & & South Weber & 12TVA2253 & 41.121 & 111.935 & 199 \\
\hline & & Sunset & 12TVA 1453 & 41.121 & 112.030 & 200 \\
\hline & & Syracuse & 12TVA 1049 & 41.084 & 112.077 & 201 \\
\hline & & West Point & 12TVA0952 & 41.111 & 112.089 & 202 \\
\hline & South Davis & Bountiful & 12TVA2626 & 40.879 & 111.884 & 204 \\
\hline & & Centerville & 12TVA2629 & 40.906 & 111.884 & 205 \\
\hline & & Farmington & 12TVA2536 & 40.969 & 111.897 & 206 \\
\hline & & North Salt Lake & 12TVA2321 & 40.833 & 111.919 & 207 \\
\hline & & West Bountiful & 12TVA2427 & 40.887 & 111.908 & 208 \\
\hline & & Woods Cross & 12TVA2425 & 40.869 & 111.907 & 209 \\
\hline Duchesne & Altamont & Altamont & 12TWV6168 & 40.357 & 110.287 & 212 \\
\hline & Duchesne & Duchesne & 12 TWV5145 & 40.151 & 110.407 & 214 \\
\hline & Myton & Myton & 12TWV8050 & 40.194 & 110.066 & 216 \\
\hline & Roosevelt & Roosevelt & 12TWV8761 & 40.292 & 109.982 & 218 \\
\hline & Tabiona & Tabiona & 12TWV2467 & 40.350 & 110.723 & 220 \\
\hline Emery & Castle Dale-Huntington & Castle Dale & 12SVU9840 & 39.206 & 111.028 & 223 \\
\hline & & Cleveland & 12SWU1355 & 39.341 & 110.854 & 224 \\
\hline & & Elmo & 12SWUI559 & 39.377 & 110.831 & 225 \\
\hline & & Huntington & 12SWU0353 & 39.323 & 110.971 & 227 \\
\hline & & Orangeville & 12SVU9542 & 39.224 & 111.063 & 228 \\
\hline & Emery-Ferron & Emery & 12SVU7808 & 38.917 & 111.259 & 230 \\
\hline & & Ferron & 12SVU8927 & 39.089 & 111.132 & 231 \\
\hline & Green River & Green River & 12SWU7316 & 38.987 & 110.162 & 233 \\
\hline Garfield & Escalante & Escalante & 12SVS4780 & 37.763 & 111.607 & 236 \\
\hline & Panguitch & Bear Valley Junction & 12SUT7502 & 37.954 & 112.428 & 913 \\
\hline & & Hatch & 12SUS7368 & 37.647 & 112.445 & 239 \\
\hline & & Hillsdale & 12SUS7875 & 37.711 & 112.389 & 928 \\
\hline & & Panguitch & I2SUS7387 & 37.818 & 112.448 & 240 \\
\hline & Tropic & Antimony & 12SVT1219 & 38.111 & 112.009 & 242 \\
\hline & & Bryce Canyon & 12SUS9765 & 37.623 & 112.172 & 917 \\
\hline & & Cannonville & 12SVS0658 & 37.561 & 112.069 & 243 \\
\hline
\end{tabular}




\begin{tabular}{|c|c|c|c|c|c|c|}
\hline & & Henrieville & 12SVS1258 & 37.562 & 112.002 & 244 \\
\hline & & Tropic & 12SVS0464 & 37.615 & 112.093 & 245 \\
\hline Grand & Moab & Moab & 12SXT2671 & 38.575 & 109.559 & 248 \\
\hline Iron & Beryl-Newcastle & Beryl & 12STS6797 & 37.887 & 113.655 & 9 \\
\hline & & Beryl Junction & 12STS6677 & 37.707 & 113.660 & 915 \\
\hline & & Hamlin Valley & 12STT3910 & 37.997 & 113.977 & 926 \\
\hline & & Lund & 12STT8609 & 38.000 & 113.442 & 93 \\
\hline & & Modena & 12STS4387 & 37.791 & 113.924 & 933 \\
\hline & & Newcastle & 12STS7671 & 37.656 & 113.544 & 936 \\
\hline & & Uvada & 11SQM6078 & 37.709 & 114.056 & 9 \\
\hline & & Zane & $12 S T T 7400$ & 37.916 & 113.576 & 947 \\
\hline & Cedar City & Cedar City & 12SUS1871 & 37.665 & 113.069 & 254 \\
\hline & & Colombia Mine & 12STS9066 & 37.614 & 113.384 & 963 \\
\hline & & Enoch & 12SUS2282 & 37.765 & 113.026 & 92 \\
\hline & & Hamilton Fort & 12SUS1266 & 37.619 & 113.135 & 92 \\
\hline & & Kanarraville & 12SUS0756 & 37.528 & 113.189 & 255 \\
\hline & Parowan & Paragonah & 12SUS4494 & 37.877 & 112.779 & 25 \\
\hline & & Parowan & 12SUS3990 & 37.840 & 112.835 & 258 \\
\hline & & Summit & 12SUS3085 & 37.793 & 112.936 & 942 \\
\hline Juab & Eureka & Eureka & 12SVV0423 & 39.949 & 112.129 & 261 \\
\hline & Nephi & Levan & 12SVU2679 & 39.554 & 111.867 & 26 \\
\hline & & Mona & 12SVV2707 & 39.807 & 111.858 & 264 \\
\hline & & Nephi & 12SVU2996 & 39.708 & 111.834 & 265 \\
\hline Kane & Kanab & Kanab & 12SUS6401 & 37.042 & 112.534 & 26 \\
\hline & Orderville & Alton & 12SUS6944 & 37.430 & 112.486 & 271 \\
\hline & & Duck Creek Forest Camp & 12SUS6150 & 37.483 & 112.577 & \\
\hline & & Glendale & 12SUS5931 & 37.312 & 112.596 & 27 \\
\hline & & Long Valley Junction & 12SUS6649 & 37.475 & 112.521 & 9 \\
\hline & & Mount Carmel & 12SUS5223 & 37.239 & 112.674 & \\
\hline & & Mount Carmel Junction & 12SUS5120 & 37.211 & 112.684 & 93 \\
\hline & & Orderville & 12SUS5526 & 37.266 & 112.640 & 273 \\
\hline Millard & Delta & Delta & 12SUU6457 & 39.349 & 112.584 & 27 \\
\hline & & Hinckley & 12SUU5754 & 39.320 & 112.664 & 2 \\
\hline & & Leamington & 12SUU9076 & 39.523 & 112.285 & 27 \\
\hline & & Lynndyl & 12SUU8275 & 39.513 & 112.378 & 279 \\
\hline & Fillmore & Black Rock & 12SUT2987 & 38.712 & 112.972 & 91 \\
\hline & & Cove Fort & 12SUT6273 & 38.592 & 112.590 & $9 !$ \\
\hline & & Fillmore & 12SUU8414 & 38.964 & 112.344 & 281 \\
\hline & & Kanosh & 12SUT7595 & 38.792 & 112.445 & 28 \\
\hline & & Meadow & 12SUUt70s & 38.882 & 112.423 & 203 \\
\hline & Garrison-Sevier Lake & Desert Range Exper. Sta. & 12STT6175 & 38.588 & 113.749 & 9 \\
\hline & & Garrison & $11 \mathrm{SQP} 5613$ & 38.926 & 114.052 & 92 \\
\hline & Scipio & Holden & 12SUU9028 & 39.091 & 112.277 & 286 \\
\hline & & Oak City & 12SUU8458 & 39.360 & 112.352 & 287 \\
\hline & & Scipio & 12SVU0544 & 39.237 & 112.106 & 28 \\
\hline
\end{tabular}




\begin{tabular}{|c|c|c|c|c|c|}
\hline Morgan & Morgan & Morgan City & 12TVA4343 & 41.033 & 111.684 \\
\hline \multirow[t]{5}{*}{ Piute } & Circleville & Circleville & 12SUT8925 & 38.163 & 112.272 \\
\hline & & Junction & 12SUT9332 & 38.226 & 112.228 \\
\hline & & Kingston & 12SUT9629 & 38.200 & 112.193 \\
\hline & & Piute Indian Reservation & 12SUT9938 & 38.281 & 112.160 \\
\hline & Marysvale & Marysvale & 12SUT9256 & 38.443 & 112.243 \\
\hline \multirow[t]{5}{*}{ Rich } & Garden City-Laketown & Garden City & 12TVB6743 & 41.935 & 111.404 \\
\hline & & Laketown & 12TVB7330 & 41.818 & 111.331 \\
\hline & & Pickleville & 12TVB6839 & 41.899 & 111.391 \\
\hline & Randolph-Woodruff & Randolph & 12TVB8512 & 41.657 & 111.186 \\
\hline & & Woodruff & 12TVA8696 & 41.512 & 111.173 \\
\hline \multirow[t]{11}{*}{ Salt Lake } & Bingham & Bingham Canyon & 12 TVV0288 & 40.534 & 112.163 \\
\hline & Jordan & Riverton & 12TVV2086 & 40.518 & 111.950 \\
\hline & & South Jordan & 12TVV2190 & 40.554 & 111.938 \\
\hline & & West Jordan & 12TVV2095 & 40.599 & 111.951 \\
\hline & Magna & Kearns & 12TVA 1500 & 40.643 & 112.011 \\
\hline & & Magna & 12TVA0706 & 40.697 & 112.106 \\
\hline & Midvale & Midvale & 12TVV2495 & 40.599 & 111.904 \\
\hline & & Sandy City & $12 \mathrm{tVV} 2593$ & 40.581 & 111.892 \\
\hline & Salt Lake City & Salt Lake City & 12TVA2510 & 40.734 & 111.894 \\
\hline & South Salt Lake & Murray & 12TVA2502 & 40.662 & 111.893 \\
\hline & & South Salt Lake & 12TVA2608 & 40.716 & 111.882 \\
\hline \multirow[t]{2}{*}{ Sanjuan } & Blanding & Blanding & $12 S X S 3465$ & 37.619 & 109.487 \\
\hline & Monticello & Monticello & $12 S X S 4693$ & 37.870 & 109.345 \\
\hline \multirow[t]{13}{*}{ Sanpete } & Gunnison & Centerfield & 12SVU2931 & 39.122 & 111.827 \\
\hline & & Fayette & 12TVU2642 & 39.221 & 111.863 \\
\hline & & Gunnison & 12SVU2934 & 39.149 & 111.827 \\
\hline & Manti & Ephraim & 12SVU5056 & 39.349 & 111.586 \\
\hline & & Manti & 12SVU4546 & 39.258 & 111.643 \\
\hline & & Mayfield & 12TVU3929 & 39.105 & 111.711 \\
\hline & & Sterling & 12 TVU4038 & 39.186 & 111.700 \\
\hline & Mount Pleasant-Moroni & Fairview & 12SVU6386 & 39.620 & 111.436 \\
\hline & & Fountain Green & 12SVU4586 & 39.619 & 111.646 \\
\hline & & Moroni & 12SVU5075 & 39.520 & 111.587 \\
\hline & & Mount Pleasant & 12SVU6077 & 39.539 & 111.471 \\
\hline & & Spring City & 12SVU5770 & 39.475 & 111.505 \\
\hline & & Wales & $12 \mathrm{SVU} 4570$ & 39.475 & 111.645 \\
\hline \multirow[t]{4}{*}{ Sevier } & Koosharem & Koosharem & $12 S V T 2362$ & 38.500 & 111.888 \\
\hline & Monroe & Elsinore & 12SVT0082 & 38.678 & 112.155 \\
\hline & & Joseph & 12SUT9476 & 38.623 & 112.223 \\
\hline & & Monroe & 12SVT0276 & 38.624 & 112.131 \\
\hline
\end{tabular}




\begin{tabular}{|c|c|c|c|c|c|c|}
\hline & Richfield & Annabella & 12SVT0885 & 38.706 & 112.063 & 360 \\
\hline & & Glenwood & 12SVT1491 & 38.760 & 111.995 & 361 \\
\hline & & Richfield & 12SVT0692 & 38.769 & 112.087 & 362 \\
\hline & & Sigurd & 12SVT1699 & 38.833 & 111.973 & 363 \\
\hline & Salina & Aurora & 12SVU1908 & 38.914 & 111.940 & 365 \\
\hline & & Redmond & 12 SVU2517 & 38.996 & 111.871 & 366 \\
\hline & & Salina & $12 S V U 2612$ & 38.951 & 111.859 & 367 \\
\hline Summit & Coalville & Coalville & 12TVA6629 & 40.908 & 111.409 & 370 \\
\hline & & Henefer & 12TVA5840 & 41.007 & 111.505 & 371 \\
\hline & Kamas & Francis & 12TVV7695 & 40.602 & 111.289 & 373 \\
\hline & & Kamas & 12TVV7699 & 40.638 & 111.289 & 374 \\
\hline & & Oakley & 12TVA7407 & 40.710 & 111.313 & 375 \\
\hline & Park City & Park City & 12TVA5700 & 40.647 & 111.514 & 377 \\
\hline Tooele & Dugway-Wendover & Wendover & $11 \mathrm{TQR} 5013$ & 40.727 & 114.045 & 380 \\
\hline & Onaqui & Ophir & 12TUV9369 & 40.362 & 112.266 & 383 \\
\hline & Tooele-Grantsville & Grantsville & 12TUV7695 & 40.593 & 112.471 & 385 \\
\hline & & Stockton & 12TUV8478 & 40.441 & 112.373 & 386 \\
\hline & & Tooele & 12TUV9087 & 40.523 & 112.304 & 387 \\
\hline Uintah & Vernal & Maeser & $12 T X V 8021$ & 39.917 & 108.899 & 393 \\
\hline & & Vernal & 12 TXV7925 & 40.458 & 109.531 & 394 \\
\hline Utah & American Fork & Alpine & 12TVV3478 & 40.447 & 111.784 & 398 \\
\hline & & American Fork & 12 TVV3270 & 40.375 & 111.806 & 399 \\
\hline & Goshen & Genola & 12SVV2828 & 39.996 & 111.849 & 401 \\
\hline & & Goshen & 12SVV2322 & 39.941 & MI.907 & 402 \\
\hline & Lehi & Lehi & 12TVV2871 & 40.383 & 111.854 & 404 \\
\hline & Orem & Orem & 12TVV4062 & 40.303 & 111.711 & 406 \\
\hline & Payson-Salem & Payson & 12TVV3733 & 40.042 & 111.744 & 408 \\
\hline & & Salem & 12TVV4334 & 40.051 & 111.674 & 409 \\
\hline & & Santaquin & $12 S V \sqrt{3325}$ & 39.969 & 111.790 & 410 \\
\hline & Pleasant Grove & Lindon & 12TVV3966 & 40.339 & 111.724 & 412 \\
\hline & & Pleasant Grove & 12TVV3768 & 40.357 & 111.747 & 413 \\
\hline & Provo & Provo & 12TVV4555 & 40.241 & 111.652 & 415 \\
\hline & Spanish Fork & Spanish Fork & 12TVV4540 & 40.105 & 111.651 & 417 \\
\hline & Springville-Mapleton & Mapleton & 12TVV5042 & 40.124 & 111.592 & 419 \\
\hline & & Springville & $12 T V V 4846$ & 40.160 & 111.616 & 420 \\
\hline Wasatch & Heber & Charleston & 12TVV6079 & 40.458 & 111.477 & 423 \\
\hline & & Heber City & 12TVV6584 & 40.503 & 111.418 & 424 \\
\hline & & Midway & $12 \mathrm{TVV} 6084$ & 40.503 & 111.477 & 425 \\
\hline & Strawberry Valley & Soldier Summit & 12 TVV9319 & 39.918 & 111.087 & 428 \\
\hline
\end{tabular}




\begin{tabular}{|c|c|c|c|c|c|c|}
\hline County & Township & Location Name & UTM & Lat $\left({ }^{\circ} \mathrm{N}\right)$ & Long $\left({ }^{\circ} \mathrm{W}\right)$ & Ctrl \# \\
\hline \multirow{32}{*}{ Washington } & \multirow[t]{5}{*}{ Enterprise } & Central & $12 S T S 6844$ & 37.410 & 113.626 & 431 \\
\hline & & Enterprise & 12STS6062 & 37.571 & 113.723 & 432 \\
\hline & & Mountain Meadow & 12STS6955 & 37.510 & 113.619 & 2014 \\
\hline & & Pine Valley & 12STS7841 & 37.386 & 113.513 & 961 \\
\hline & & Pinto & 12STS7857 & 37.530 & 113.518 & 965 \\
\hline & \multirow[t]{14}{*}{ Hurricane } & Anderson Junction & 12STS9628 & 37.273 & 113.306 & 912 \\
\hline & & Grafton & 12SUS1515 & 37.160 & 113.089 & 2001 \\
\hline & & Hilldale & 12SUR1998 & 37.007 & 113.039 & 2012 \\
\hline & & Hurricane & $12 S T S 9716$ & 37.165 & 113.291 & 434 \\
\hline & & Laverkin & 12STS9819 & 37.192 & 113.281 & 435 \\
\hline & & Leeds & $12 \mathrm{STS} 9123$ & 37.227 & 113.361 & 436 \\
\hline & & New Harmony & $12 S T S 9650$ & 37.471 & 113.312 & 437 \\
\hline & & Pintura & 12STS9935 & 37.337 & 113.274 & 938 \\
\hline & & Rockville & 12SUS1914 & 37.152 & 113.043 & 939 \\
\hline & & Springdale & 12SUS2317 & 37.179 & 112.999 & 438 \\
\hline & & Toquerville & 12STS9825 & 37.246 & 113.283 & 439 \\
\hline & & Vic's Place & 12STS9629 & 37.282 & 113.306 & 945 \\
\hline & & Virgin & 12SUS0618 & 37.185 & 113.191 & 440 \\
\hline & & Zion Lodge & $12 S U S 2419$ & 37.198 & 112.988 & 948 \\
\hline & \multirow{13}{*}{ St. George } & Bloomington & 12STS6803 & 37.041 & 113.614 & 2000 \\
\hline & & Castle Cliff & 12STS4405 & 37.053 & 113.884 & 962 \\
\hline & & Goldstrike & $12 S T S 4341$ & 37.377 & 113.908 & 964 \\
\hline & & Gunlock & 12STS5530 & 37.281 & 113.769 & 924 \\
\hline & & Harrisburg Junction & 12STS8415 & 37.153 & 113.437 & 2002 \\
\hline & & Ivins & $12 S T S 6316$ & 37.157 & 113.674 & 442 \\
\hline & & Middleton & 12STS7411 & 37.115 & 113.549 & 2003 \\
\hline & & Santa Clara & 12STS6412 & 37.121 & 113.661 & 444 \\
\hline & & Shivwits & 12STS5618 & 37.173 & 113.753 & 941 \\
\hline & & St. George & 12STS7110 & 37.105 & 113.582 & 443 \\
\hline & & Veyo & 12STS6235 & 37.328 & 113.691 & 944 \\
\hline & & Vic's Service Station & 12STS4304 & 37.044 & 113.895 & 946 \\
\hline & & Washington & $12 S T S 7712$ & 37.125 & 113.515 & 445 \\
\hline \multirow[t]{4}{*}{ Wayne } & Hanksville & Hanksville & 12 SWT2547 & 38.368 & 110.719 & 752 \\
\hline & \multirow[t]{3}{*}{ Loa } & Bicknell & 12SVT5243 & 38.331 & 111.554 & 449 \\
\hline & & Loa & 12SVT4450 & 38.393 & 111.646 & 450 \\
\hline & & Torrey & 12SVT6339 & 38.295 & 111.428 & 451 \\
\hline \multirow[t]{10}{*}{ Weber } & Ogden & Ogden & 12TVA 1963 & 41.211 & 111.972 & 454 \\
\hline & Ogden Valley & Huntsville & 12TVA3567 & 41.249 & 111.781 & 456 \\
\hline & \multirow[t]{3}{*}{ Weber North } & North Ogden & 12TVA 1973 & 41.301 & 111.973 & 458 \\
\hline & & Plain City & 12TVA0973 & 41.300 & 112.092 & 459 \\
\hline & & Pleasant View & 12TVA 1674 & 41.310 & 112.009 & 460 \\
\hline & \multirow[t]{3}{*}{ Weber Southeast } & South Ogden & 12TVA2061 & 41.193 & 111.959 & 462 \\
\hline & & Uintah & 12TVA2254 & 41.130 & 111.935 & 463 \\
\hline & & Washington Terrace & 12 TVA 1859 & 41.175 & 111.983 & 464 \\
\hline & \multirow[t]{2}{*}{ Weber Southwest } & Riverdale & 12TVA 1357 & 41.157 & 112.042 & 466 \\
\hline & & Roy & 12TVA1357 & 41.157 & 112.042 & 467 \\
\hline
\end{tabular}




\section{APPENDIX B}

\section{RECORD FORMAT FOR THE TOWN DATA BASE}

This is the basic format for the Town Data Base. Each set of three 132-character records contains all the information for an estimate.

Record 1

\begin{tabular}{|c|c|c|}
\hline & Blank & 1 \\
\hline \multirow[t]{2}{*}{ CNTRL } & Location control \# from REECO & $2-5$ \\
\hline & Blank & 6 \\
\hline \multirow[t]{2}{*}{ EVENT } & Event name (1st 10 characters) & $7-16$ \\
\hline & Blank & 17 \\
\hline \multirow[t]{2}{*}{ ORIG } & $\begin{array}{l}\text { Origin of estimate } \\
\mathrm{I}=10-\mathrm{km} \text { Grid Data Base; } \\
\mathrm{R}=\text { Survey Meter Data Base; } \\
\mathrm{X}=\text { County Data Base }\end{array}$ & 18 \\
\hline & Blank & 19 \\
\hline \multirow[t]{2}{*}{ RECNO } & Record Number - "1" & 20 \\
\hline & Blank & 21 \\
\hline \multirow[t]{2}{*}{$\mathrm{N}$} & Counter from FATHER runs & $22-27$ \\
\hline & Blank & 28 \\
\hline \multirow[t]{2}{*}{ YYMMDD } & Event date (year, month, day) & $29-34$ \\
\hline & Blank & 35 \\
\hline \multirow[t]{2}{*}{ STATE } & State abbreviation & $36-37$ \\
\hline & Blank & 38 \\
\hline COUNTY & County name for Location & $39-65$ \\
\hline PHASE & $\begin{array}{l}\text { Blank if location is in Phase I region, } \\
\text { "+" if not }\end{array}$ & 66 \\
\hline \multirow[t]{2}{*}{ RUN } & DRI run number & $67-68$ \\
\hline & Blank & 69 \\
\hline \multirow[t]{2}{*}{ TWNSHIP } & Township name for Location & $70-99$ \\
\hline & Blank & 100 \\
\hline LOCALE & Name for Location & $101-130$ \\
\hline $\mathrm{DEC}^{\mathrm{a}}$ & Decision \# & $131-132$ \\
\hline
\end{tabular}


Record 2

\begin{tabular}{|c|c|c|}
\hline & Blank & 1 \\
\hline \multirow[t]{2}{*}{ CNTRL } & Location control \# from REECO & $2-5$ \\
\hline & Blank & 6 \\
\hline \multirow[t]{2}{*}{ EVENT } & Event name (1st 10 characters) & $7-16$ \\
\hline & Blank & 17 \\
\hline \multirow[t]{2}{*}{ ORIG } & $\begin{array}{l}\text { Origin of estimate } \\
\mathrm{I}=10-\mathrm{km} \text { Grid Data Base; } \\
\mathrm{R}=\text { Survey Meter Data Base; } \\
\mathrm{X}=\text { County Data Base }\end{array}$ & 18 \\
\hline & Blank & 19 \\
\hline \multirow[t]{2}{*}{ RECNO } & Record Number - “2” & 20 \\
\hline & Blank & 21 \\
\hline UTM & UTM Coordinate for Location & $22-30$ \\
\hline \multirow[t]{2}{*}{$\mathrm{H} 12$} & $\mathrm{X}_{\mathrm{E}}$ Estimate (1PE10.1) & $31-40$ \\
\hline & Blank & 41 \\
\hline \multirow[t]{2}{*}{$\mathrm{H} 12 \mathrm{D}$} & $\mathrm{S}_{\mathrm{E}}$ Estimate (1PE10.2) & $42-51$ \\
\hline & Blank & 51 \\
\hline \multirow[t]{2}{*}{ TA } & $\mathrm{X}_{\mathrm{T}}$ Estimate (1PE10.1) & $53-62$ \\
\hline & Blank & 63 \\
\hline \multirow[t]{2}{*}{ TAD } & $\mathrm{S}_{\mathrm{T}}$ Estimate (1PE10.1) & $64-73$ \\
\hline & Blank & $74-75$ \\
\hline \multirow[t]{2}{*}{ DATE } & Date of FATHER run (YY/MM/DD) & $76-83$ \\
\hline & Blank & 84 \\
\hline \multirow[t]{2}{*}{ TIME } & Time of FATHER run & $85-92$ \\
\hline & Blank & $93-94$ \\
\hline \multirow[t]{2}{*}{ NP } & Number of points used in estimate & $95-98$ \\
\hline & Blank & 99 \\
\hline \multirow[t]{2}{*}{ USE } & $\begin{array}{l}\text { Usability code for estimate } \\
\text { (Y - yes; D - yes but no population) }\end{array}$ & 100 \\
\hline & Blank & 101 \\
\hline \multirow[t]{2}{*}{ EVNUM } & Event number & $102-104$ \\
\hline & Blank & 105 \\
\hline \multirow[t]{2}{*}{ RUN } & DRI Subset \# for Location & 106-107 \\
\hline & Blank & $108-130$ \\
\hline $\mathrm{DEC}^{\mathrm{a}}$ & Decision \# & $131-132$ \\
\hline
\end{tabular}


Record 3

\begin{tabular}{|c|c|c|}
\hline & Blank & 1 \\
\hline \multirow[t]{2}{*}{ CNTRL } & Location control \# from REECO & $2-5$ \\
\hline & Blank & 6 \\
\hline \multirow[t]{2}{*}{ EVENT } & Event name (1st 10 characters) & $7-16$ \\
\hline & Blank & 17 \\
\hline \multirow[t]{2}{*}{ ORIG } & $\begin{array}{l}\text { Origin of estimate } \\
\mathrm{I}=10-\mathrm{km} \text { Grid Data Base; } \\
\mathrm{R}=\text { Survey Meter Data Base; } \\
\mathrm{X}=\text { County Data Base }\end{array}$ & 18 \\
\hline & Blank & 19 \\
\hline \multirow[t]{2}{*}{ RECNO } & Record Number - "3" & 20 \\
\hline & Blank & 21 \\
\hline \multirow[t]{2}{*}{ ZSMX } & $\begin{array}{l}\text { Sum of } \mathrm{H}+12 \text { values used, if } \\
\text { SMDB data only(IPE11.3) }\end{array}$ & $22-32$ \\
\hline & Blank & 33 \\
\hline \multirow[t]{2}{*}{ ZSMX2 } & $\begin{array}{l}\text { Sum of } \mathrm{H}+12 \text { values squared, } \\
\text { if SMDB data only(1PE11.3) }\end{array}$ & $34-44$ \\
\hline & Blank & 45 \\
\hline \multirow[t]{2}{*}{ NAMEAN } & $\begin{array}{l}\text { Arithmetic mean of } \mathrm{H}+12 \\
\text { values, SMDB data only (1PE11.3) }\end{array}$ & $46-56$ \\
\hline & Blank & 57 \\
\hline \multirow[t]{2}{*}{ NASIG } & $\begin{array}{l}\text { Arithmetic std deviation of } \mathrm{H}+12 \\
\text { values, SMDB data only( } 1 \mathrm{PE} 11.3)\end{array}$ & $58-68$ \\
\hline & Blank & 69 \\
\hline \multirow[t]{2}{*}{$\mathrm{CASE}^{\mathrm{b}}$} & $\begin{array}{l}\text { Case code (If ORIG = R, A thru J; } \\
\text { if ORIG }=I, Z \text {.) }\end{array}$ & 70 \\
\hline & Blank & 71 \\
\hline \multirow[t]{2}{*}{ LONG } & Longitude for Location & $72-80$ \\
\hline & Blank & 81 \\
\hline \multirow[t]{2}{*}{ LAT } & Latitude for Location & $82-89$ \\
\hline & Blank & 90 \\
\hline \multirow[t]{2}{*}{ EVENT } & Event name (full 20 characters) & $91-110$ \\
\hline & Blank & $111-130$ \\
\hline $\mathrm{DEC}^{\mathrm{a}}$ & Decision \# & $131-132$ \\
\hline
\end{tabular}

Notes:

a. Determined by program DECCMB (Section 5.2.2)

b. Determined by program H12 (Section 5.1) 


\section{APPENDIX C}

\section{SELECTED INFORMATION FROM THE TOWN DATA BASE, VERSION 4.2}

Listed below are the estimates of exposure rate and time of fallout arrival for each location and event in the Town Data Base. The variable names are defined in Appendix B. An asterisk by an event name indicates that some values have been changed from the previous version of the data base.

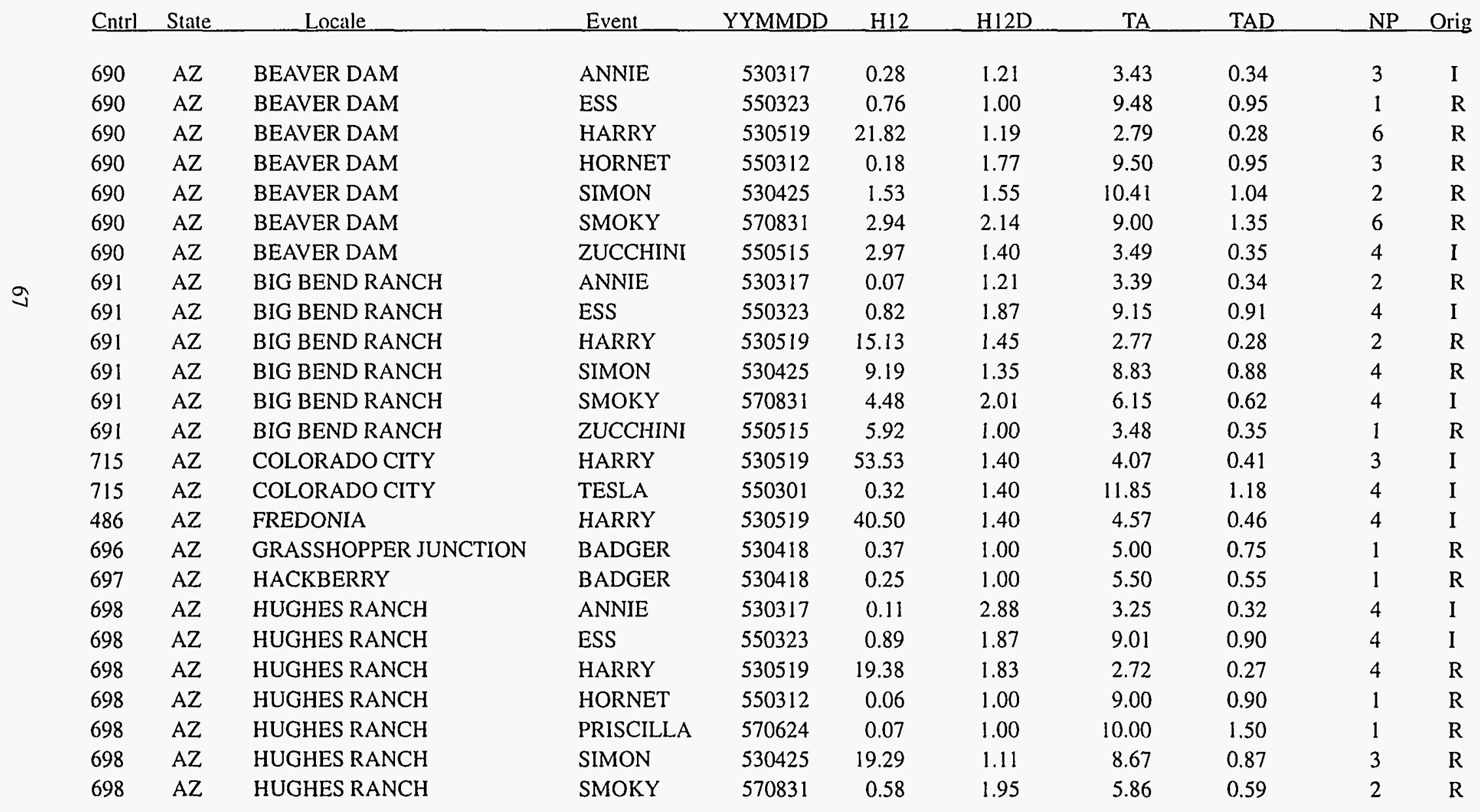


Cnirl State Locale

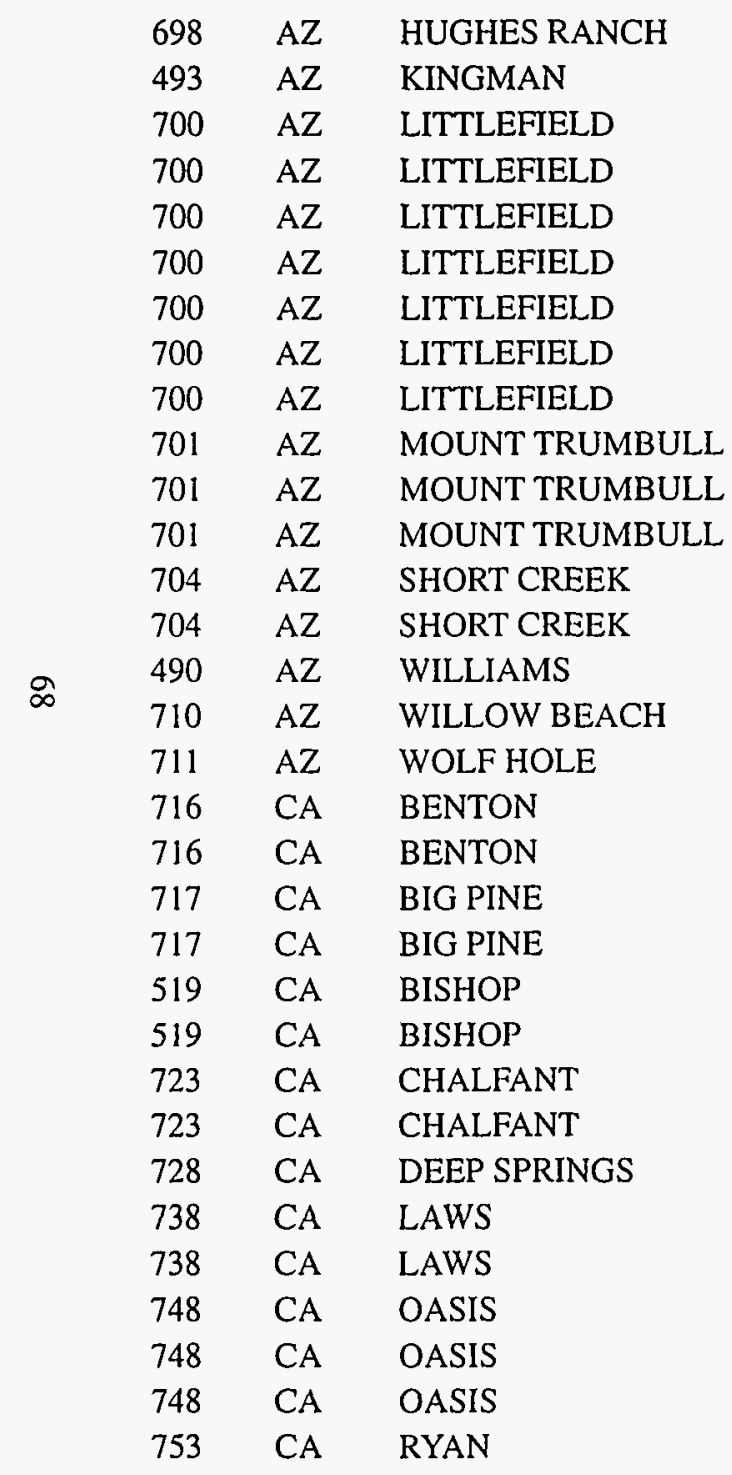

Event

YYMMDD

$\mathrm{H} 12$

H12D TA TAD NP Orig

$\begin{array}{lrrrrrrl}\text { ZUCCHINI } & 550515 & 2.06 & 1.00 & 3.39 & 0.34 & \mathrm{l} & \mathrm{R} \\ \text { BADGER } & 530418 & 0.25 & 1.01 & 5.50 & 0.82 & 2 & \mathrm{R} \\ \text { ANNIE } & 530317 & 0.21 & 1.21 & 3.47 & 0.35 & 3 & \mathrm{I} \\ \text { ESS } & 550323 & 0.76 & 1.00 & 9.52 & 0.95 & 1 & \mathrm{R} \\ \text { HARRY } & 530519 & 22.18 & 1.17 & 2.80 & 0.28 & 7 & \mathrm{R} \\ \text { HORNET } & 550312 & 0.29 & 1.00 & 9.50 & 0.95 & 2 & \mathrm{R} \\ \text { SIMON } & 530425 & 1.53 & 1.55 & 10.24 & 1.02 & 2 & \mathrm{R} \\ \text { SMOKY } & 570831 & 2.64 & 2.10 & 8.00 & 1.20 & 4 & \mathrm{R} \\ \text { ZUCCHINI } & 550515 & 2.60 & 1.40 & 3.54 & 0.35 & 4 & \mathrm{I} \\ \text { BADGER } & 530418 & 8.82 & 1.40 & 4.00 & 0.40 & 4 & \mathrm{I} \\ \text { CLIMAX } & 530604 & 4.00 & 1.40 & 8.27 & 0.83 & 4 & \mathrm{I} \\ \text { SIMON } & 530425 & 39.78 & 1.40 & 6.84 & 0.68 & 4 & \mathrm{I} \\ \text { HARRY } & 530519 & 54.10 & 1.40 & 4.05 & 0.41 & 3 & \mathrm{I} \\ \text { TESLA } & 550301 & 0.33 & 1.40 & 11.83 & 1.18 & 4 & \mathrm{I} \\ \text { BADGER } & 530418 & 0.10 & 1.00 & 7.50 & 1.13 & 1 & \mathrm{R} \\ \text { BEE } & 550322 & 0.44 & 1.40 & 4.00 & 0.40 & 4 & \mathrm{I} \\ \text { HORNET } & 550312 & 0.09 & 1.00 & 11.00 & 1.65 & 1 & \mathrm{R} \\ \text { KEPLER } & 570724 & 1.03 & 1.40 & 13.68 & 1.37 & 4 & \mathrm{I} \\ \text { WHITNEY } & 570923 & 0.38 & 1.00 & 13.70 & 2.06 & 2 & \mathrm{R} \\ \text { BOLTZMANN } & 570528 & 0.12 & 1.00 & 60.00 & 9.00 & 1 & \mathrm{R} \\ \text { KEPLER } & 570724 & 0.52 & 1.40 & 11.70 & 1.17 & 3 & \mathrm{I} \\ \text { KEPLER } & 570724 & 1.01 & 1.40 & 12.04 & 1.20 & 4 & \mathrm{I} \\ \text { WHITNEY } & 570923 & 0.34 & 1.00 & 12.50 & 1.88 & 1 & \mathrm{R} \\ \text { KEPLER } & 570724 & 1.04 & 1.40 & 12.61 & 1.26 & 4 & \mathrm{I} \\ \text { WHITNEY } & 570923 & 0.34 & 1.00 & 12.70 & 1.90 & 1 & \mathrm{R} \\ \text { KEPLER } & 570724 & 0.63 & 1.40 & 10.12 & 1.01 & 4 & \mathrm{I} \\ \text { KEPLER } & 570724 & 1.06 & 1.40 & 12.14 & 1.21 & 4 & \mathrm{I} \\ \text { WHITNEY } & 570923 & 0.28 & 1.00 & 12.00 & 1.80 & 1 & \mathrm{R} \\ \text { KEPLER } & 570724 & 0.73 & 1.21 & 9.66 & 0.97 & 3 & \mathrm{R} \\ \text { WHEELER } & 570906 & 0.09 & 1.00 & 15.00 & 2.25 & 1 & \mathrm{R} \\ \text { WHITNEY } & 570923 & 0.89 & 1.11 & 10.00 & 1.00 & 3 & \mathrm{R} \\ \text { QUAY } & 581010 & 0.10 & 1.40 & 4.94 & 0.49 & 4 & \mathrm{I}\end{array}$




\begin{tabular}{|c|c|c|c|c|c|c|c|c|c|c|}
\hline Cntrl & State & Locale & Event & YYMMDD & $\mathrm{H} 12$ & $\mathrm{H} 12 \mathrm{D}$ & $\mathrm{TA}$ & TAD & NP & Orig \\
\hline 754 & $\mathrm{CA}$ & SHOSHONE & BANDICOOT & 621019 & 0.09 & 1.72 & 5.36 & 0.80 & 4 & $\mathrm{R}$ \\
\hline 757 & $\mathrm{CA}$ & STOVEPIPE WELLS & QUAY & 581010 & 0.07 & 2.85 & 5.10 & 0.51 & 2 & $\mathrm{R}$ \\
\hline 757 & $\mathrm{CA}$ & STOVEPIPE WELLS & WILSON & 570618 & 0.37 & 1.00 & 10.50 & 1.58 & 2 & $\mathrm{R}$ \\
\hline 759 & $\mathrm{CA}$ & TOM'S PLACE & KEPLER & 570724 & 0.50 & 1.40 & 13.49 & 1.35 & 3 & I \\
\hline 764 & NV & A \& B MINE & APPLE-2 & 550505 & 0.88 & 2.37 & 4.76 & 0.48 & 4 & I \\
\hline 764 & NV & A \& B MINE & BANEBERRY & 701218 & 0.15 & 1.61 & 8.08 & 0.81 & 4 & I \\
\hline 764 & NV & A \& B MINE & BOLTZMANN & 570528 & 63.54 & 1.31 & 4.38 & 0.44 & 3 & $\mathrm{R}$ \\
\hline 764 & NV & A \& B MINE & GALILEO & 570902 & 2.68 & 1.27 & 12.00 & 1.20 & 4 & $\mathbf{R}$ \\
\hline 764 & NV & A \& B MINE & GEORGE & 520601 & 0.45 & 1.40 & 5.56 & 0.56 & 4 & I \\
\hline 764 & NV & A \& B MINE & HOW & 520605 & 8.99 & 1.35 & 4.00 & 0.40 & 4 & I \\
\hline 764 & NV & A \& B MINE & JOHNIE BOY & 620711 & 0.11 & 1.62 & 2.57 & 0.26 & 9 & $\mathrm{R}$ \\
\hline 764 & NV & A \& B MINE & LEA & 581013 & 0.12 & 1.52 & 11.00 & 1.10 & 4 & I \\
\hline 764 & NV & A \& B MINE & OWENS & 570725 & 0.21 & 1.00 & 4.50 & 0.45 & 1 & $\mathrm{R}$ \\
\hline 764 & NV & A \& B MINE & PALANQUIN & 650414 & 0.20 & 2.37 & 8.16 & 0.82 & 4 & I \\
\hline 764 & NV & A \& B MINE & SCHOONER & 681208 & 0.06 & 1.66 & 4.02 & 0.40 & 4 & I \\
\hline 764 & NV & A \& B MINE & SUGAR & 511119 & 0.44 & 1.40 & 2.00 & 0.20 & 4 & I \\
\hline 764 & NV & A \& B MINE & TURK & 550307 & 0.44 & 1.24 & 10.77 & 1.08 & 3 & I \\
\hline 765 & NV & ACOMA & APPLE-I & 550329 & 3.19 & 1.40 & 4.00 & 0.40 & 4 & I \\
\hline 765 & NV & ACOMA & FOX & 520525 & 1.17 & 1.40 & 9.09 & 0.91 & 4 & I \\
\hline 765 & NV & ACOMA & HARRY & 530519 & 11.99 & 1.40 & 3.61 & 0.36 & 4 & $I$ \\
\hline 765 & NV & ACOMA & MET & 550415 & 46.63 & 1.40 & 4.00 & 0.40 & 4 & I \\
\hline 765 & NV & ACOMA & MORGAN & 571007 & 0.10 & 1.40 & 3.16 & 0.32 & 3 & I \\
\hline 765 & NV & ACOMA & PRISCILLA & 570624 & 1.00 & 1.40 & 7.29 & 0.73 & 3 & I \\
\hline 765 & NV & ACOMA & SIMON & 530425 & 1.00 & 1.40 & 13.77 & 1.38 & 4 & I \\
\hline 766 & NV & ADAM'S RANCH & APPLE-2 & 550505 & 0.71 & 1.40 & 6.17 & 0.62 & 4 & I \\
\hline 766 & NV & ADAM'S RANCH & DIABLO & 570715 & 6.32 & 1.00 & 11.21 & 1.12 & 1 & $\mathrm{R}$ \\
\hline 766 & NV & ADAM'S RANCH & DOPPLER & 570823 & 0.53 & 1.40 & 9.29 & 0.93 & 4 & I \\
\hline 766 & NV & ADAM'S RANCH & EASY & 520507 & 5.65 & 1.40 & 2.84 & 0.28 & 3 & I \\
\hline 766 & NV & ADAM'S RANCH & GRABLE & 530525 & 0.94 & 1.40 & 3.00 & 0.30 & 4 & I \\
\hline 766 & NV & ADAM'S RANCH & HOOD & 570705 & 0.17 & 1.07 & 7.00 & 0.70 & 4 & $\mathrm{R}$ \\
\hline 766 & NV & ADAM'S RANCH & NANCY & 530324 & 3.21 & 1.22 & 5.36 & 0.54 & 2 & $\mathrm{R}$ \\
\hline 766 & NV & ADAM'S RANCH & OWENS & 570725 & 0.11 & 1.40 & 5.29 & 0.53 & 4 & I \\
\hline 766 & NV & ADAM'S RANCH & SCHOONER & 681208 & 0.33 & 1.00 & 6.27 & 0.63 & 1 & $\mathrm{R}$ \\
\hline
\end{tabular}




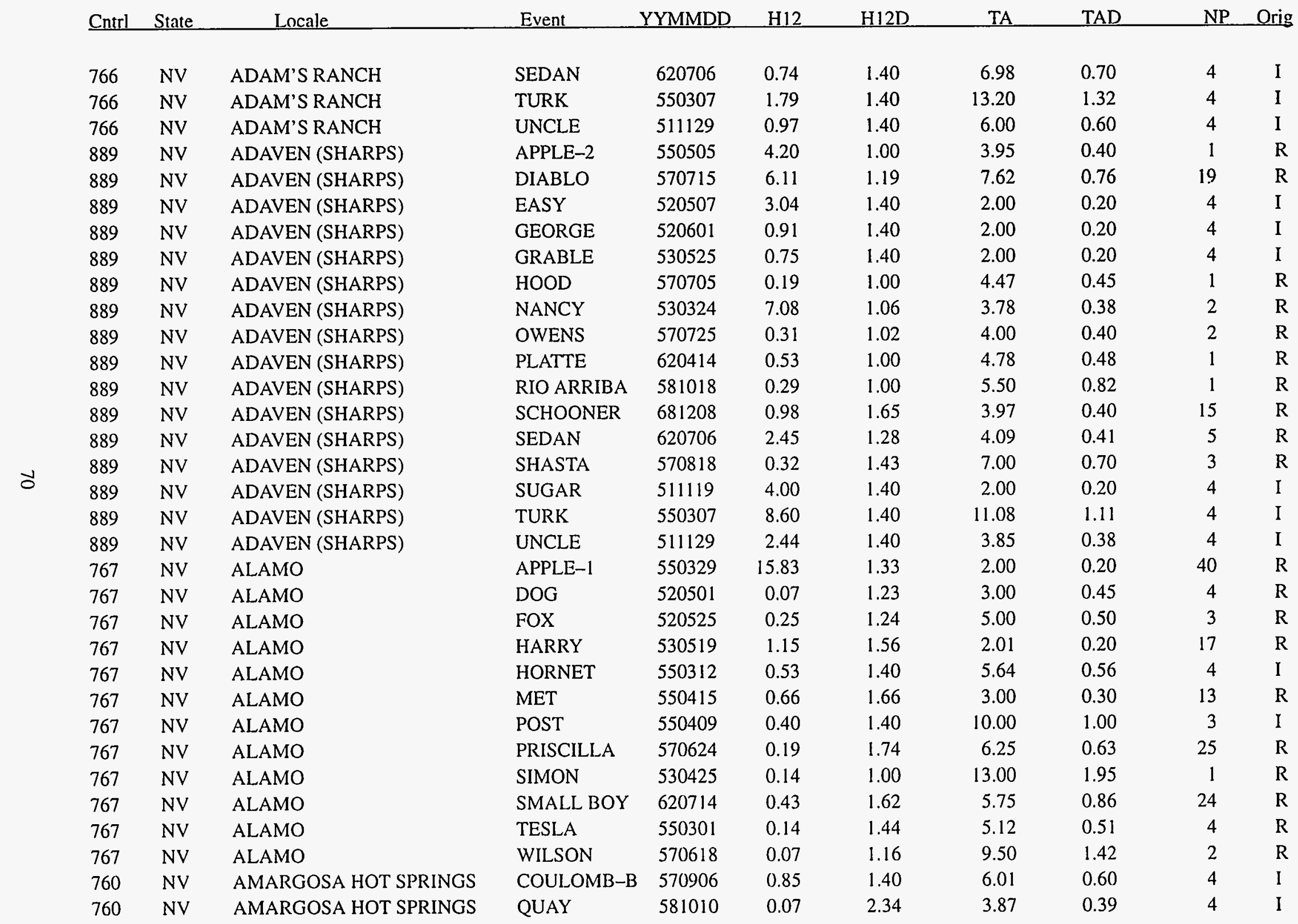




\begin{tabular}{|c|c|c|c|c|c|c|c|c|c|c|}
\hline Cntrl & State & Locale & Event & YYMMDD & $\mathrm{H} 12$ & $\mathrm{H} 12 \mathrm{D}$ & $\mathrm{TA}$ & TAD & NP & Orig \\
\hline 760 & NV & AMARGOSA HOT SPRINGS & WILSON & 570618 & 0.44 & 1.67 & 6.59 & 0.66 & 4 & I \\
\hline 768 & NV & APEX & BADGER & 530418 & 2.26 & 1.56 & 2.72 & 0.27 & 8 & $\mathrm{R}$ \\
\hline 768 & NV & APEX & CLIMAX & 530604 & 0.43 & 2.13 & 6.36 & 0.64 & 4 & I \\
\hline 768 & NV & APEX & ESS & 550323 & 0.16 & 1.00 & 4.50 & 0.45 & 1 & $\mathrm{R}$ \\
\hline 768 & NV & APEX & ZUCCHINI & 550515 & 0.38 & 1.18 & 3.66 & 0.37 & 4 & I \\
\hline 769 & NV & ASH MEADOWS & BANDICOOT & 621019 & 0.19 & 1.86 & 3.42 & 0.34 & 8 & $\mathrm{R}$ \\
\hline 770 & NV & ASH SPRINGS & APPLE-1 & 550329 & 5.00 & 1.43 & 2.11 & 0.21 & 21 & $\mathrm{R}$ \\
\hline 770 & NV & ASH SPRINGS & DOG & 520501 & 0.07 & 1.00 & 3.00 & 0.45 & 1 & $\mathrm{R}$ \\
\hline 770 & NV & ASH SPRINGS & FOX & 520525 & 0.78 & 2.13 & 5.41 & 0.54 & 4 & I \\
\hline 770 & NV & ASH SPRINGS & HARRY & 530519 & 2.34 & 2.11 & 2.30 & 0.23 & 4 & $\mathbf{R}$ \\
\hline 770 & NV & ASH SPRINGS & HIDALGO & 581005 & 0.11 & 1.40 & 8.22 & 0.82 & 4 & I \\
\hline 770 & NV & ASH SPRINGS & MET & 550415 & 0.18 & 1.85 & 4.00 & 0.40 & 2 & $\mathrm{R}$ \\
\hline 770 & NV & ASH SPRINGS & PIN STRIPE & 660425 & 0.09 & 1.73 & 3.87 & 0.39 & 311 & $\mathrm{R}$ \\
\hline 770 & NV & ASH SPRINGS & PRISCILLA & 570624 & 0.06 & 1.94 & 7.00 & 1.05 & 3 & $\mathrm{R}$ \\
\hline 770 & NV & ASH SPRINGS & SMALL BOY & 620714 & 0.09 & 1.78 & 4.96 & 0.50 & 8 & $\mathrm{R}$ \\
\hline 770 & NV & ASH SPRINGS & TESLA & 550301 & 0.83 & 1.44 & 6.00 & 0.60 & 4 & I \\
\hline 770 & NV & ASH SPRINGS & WILSON & 570618 & 0.25 & 1.88 & 9.20 & 1.38 & 3 & $\mathrm{R}$ \\
\hline 771 & NV & ATLANTA & DIABLO & 570715 & 3.33 & 1.40 & 12.23 & 1.22 & 4 & I \\
\hline 771 & NV & ATLANTA & DOPPLER & 570823 & 0.11 & 1.40 & 7.35 & 0.73 & 4 & I \\
\hline 771 & NV & ATLANTA & FOX & 520525 & 0.43 & 1.40 & 11.93 & 1.19 & 4 & I \\
\hline 771 & NV & ATLANTA & GRABLE & 530525 & 0.40 & 1.40 & 2.22 & 0.22 & 3 & I \\
\hline 771 & NV & ATLANTA & HOOD & 570705 & 0.18 & 1.40 & 8.00 & 0.80 & 4 & I \\
\hline 771 & NV & ATLANTA & NEWTON & 570916 & 0.10 & 1.40 & 4.66 & 0.47 & 4 & I \\
\hline 771 & NV & ATLANTA & SCHOONER & 681208 & 0.27 & 1.40 & 7.47 & 0.75 & 4 & I \\
\hline 771 & NV & ATLANTA & SMALL BOY & 620714 & 0.10 & 1.40 & 14.53 & 1.45 & 3 & I \\
\hline 771 & NV & ATLANTA & TURK & 550307 & 0.74 & 1.40 & 14.48 & 1.45 & 4 & $I$ \\
\hline 772 & NV & AUSTIN & BOLTZMANN & 570528 & 3.72 & 1.34 & 7.72 & 0.77 & 7 & $\mathrm{R}$ \\
\hline 772 & NV & AUSTIN & SHASTA & 570818 & 0.33 & 1.00 & 8.00 & 1.20 & 1 & $\mathrm{R}$ \\
\hline 73 & NV & BABBITT & KEPLER & 570724 & 1.92 & 1.40 & 15.00 & 1.50 & 4 & I \\
\hline 73 & NV & BABBITT & WHITNEY & 570923 & 1.00 & 1.40 & 15.32 & 1.53 & 4 & I \\
\hline 774 & NV & BAKER & APPLE-2 & 550505 & 2.92 & 1.00 & 9.18 & 0.92 & 1 & $\mathrm{R}$ \\
\hline 774 & NV & BAKER & DIABLO & 570715 & 2.46 & 1.18 & 15.05 & 1.50 & 4 & $\mathrm{R}$ \\
\hline 774 & NV & BAKER & HOOD & 570705 & 0.24 & 1.00 & 9.00 & 0.90 & 1 & $\mathrm{R}$ \\
\hline
\end{tabular}




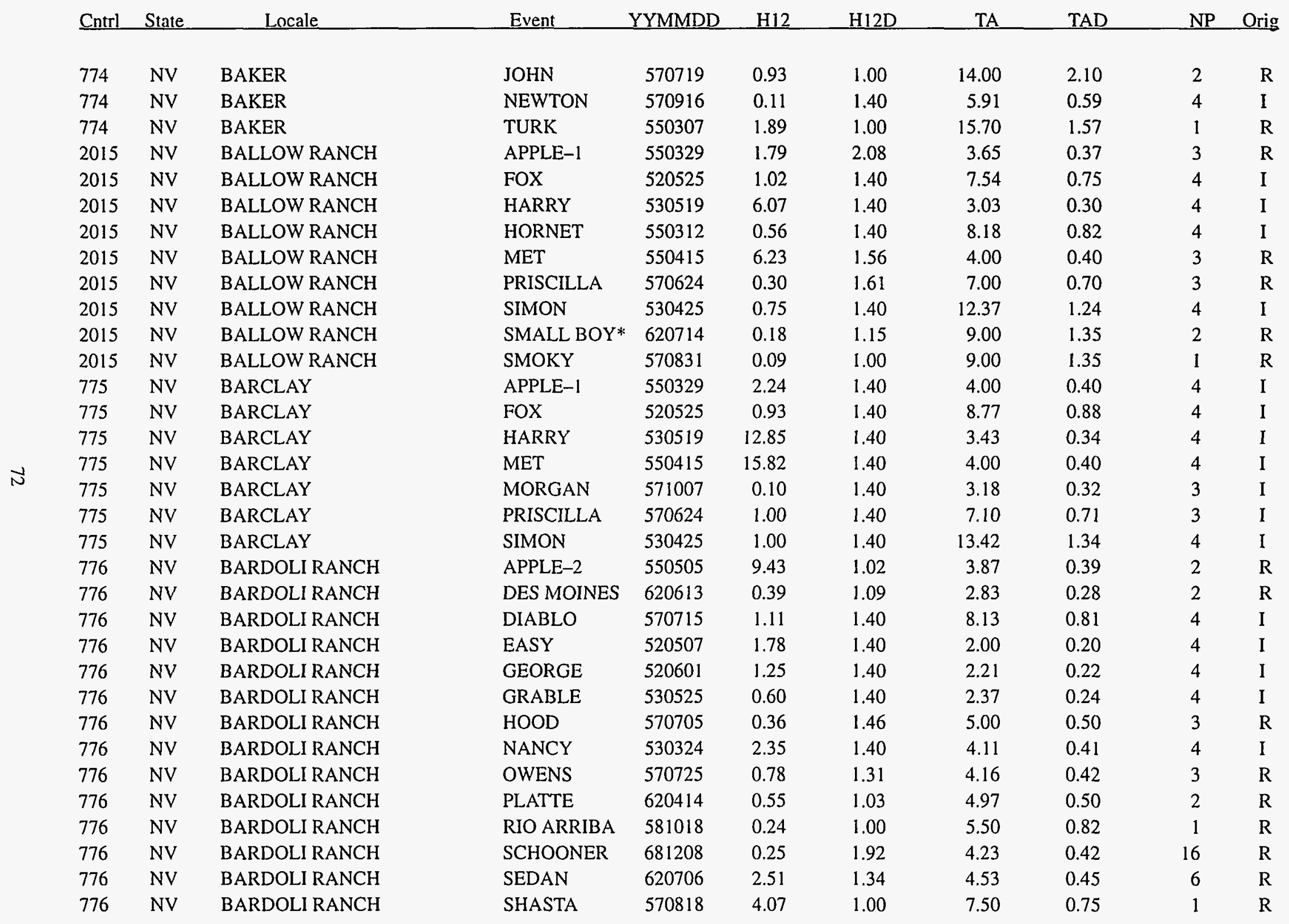




\begin{tabular}{|c|c|c|c|c|c|c|c|c|c|c|}
\hline Cntrl & State & Locale & Event & YYMMDD & $\mathrm{H} 12$ & $\mathrm{H} 12 \mathrm{D}$ & $\mathrm{TA}$ & TAD & NP & Orig \\
\hline 776 & NV & BARDOLI RANCH & SUGAR & 511119 & 4.73 & 1.40 & 2.00 & 0.20 & 4 & I \\
\hline 776 & NV & BARDOLI RANCH & TURK & 550307 & 8.75 & 1.40 & 11.22 & 1.12 & 4 & I \\
\hline 776 & NV & BARDOLI RANCH & UNCLE & 511129 & 1.25 & 1.40 & 4.00 & 0.40 & 4 & I \\
\hline 777 & NV & BASALT & BOLTZMANN & 570528 & 3.48 & 1.00 & 7.00 & 1.05 & 1 & $\mathrm{R}$ \\
\hline 777 & NV & BASALT & KEPLER & 570724 & 2.21 & 1.40 & 13.85 & 1.38 & 4 & I \\
\hline 777 & NV & BASALT & WHEELER & 570906 & 0.09 & 1.75 & 12.00 & 1.80 & 2 & $\mathrm{R}$ \\
\hline 777 & NV & BASALT & WHITNEY & 570923 & 0.30 & 1.00 & 12.30 & 1.23 & 1 & $\mathrm{R}$ \\
\hline 778 & NV & BEATTY & COULOMB-B & 570906 & 0.66 & 1.40 & 5.76 & 0.58 & 4 & I \\
\hline 778 & NV & BEATTY & QUAY & 581010 & 0.13 & 2.34 & 3.94 & 0.39 & 11 & $\mathrm{R}$ \\
\hline 778 & NV & BEATTY & WHITNEY & 570923 & 0.52 & 1.00 & 12.10 & 1.82 & 1 & $\mathrm{R}$ \\
\hline 778 & NV & BEATTY & WILSON & 570618 & 0.64 & 1.67 & 7.06 & 0.71 & 5 & $\mathrm{R}$ \\
\hline 779 & NV & BELEW RANCH & APPLE-2 & 550505 & 4.20 & 1.00 & 3.95 & 0.40 & 1 & $\mathrm{R}$ \\
\hline 779 & NV & BELEW RANCH & DIABLO & 570715 & 6.11 & 1.19 & 7.62 & 0.76 & 19 & $\mathrm{R}$ \\
\hline 779 & NV & BELEW RANCH & EASY & 520507 & 3.04 & 1.40 & 2.00 & 0.20 & 4 & I \\
\hline 779 & NV & BELEW RANCH & GEORGE & 520601 & 0.91 & 1.40 & 2.00 & 0.20 & 4 & I \\
\hline 779 & NV & BELEW RANCH & GRABLE & 530525 & 0.75 & 1.40 & 2.00 & 0.20 & 4 & I \\
\hline 779 & NV & BELEW RANCH & HOOD & 570705 & 0.19 & 1.00 & 4.47 & 0.45 & 1 & $\mathrm{R}$ \\
\hline 779 & NV & BELEW RANCH & NANCY & 530324 & 7.08 & 1.06 & 3.78 & 0.38 & 2 & $\mathrm{R}$ \\
\hline 779 & NV & BELEW RANCH & OWENS & 570725 & 0.31 & 1.02 & 4.00 & 0.40 & 2 & $\mathrm{R}$ \\
\hline 779 & NV & BELEW RANCH & PLATTE & 620414 & 0.53 & 1.00 & 4.78 & 0.48 & 1 & $\mathrm{R}$ \\
\hline 779 & NV & BELEW RANCH & RIO ARRIBA & 581018 & 0.29 & 1.00 & 5.50 & 0.82 & 1 & $\mathrm{R}$ \\
\hline 779 & NV & BELEW RANCH & SCHOONER & 681208 & 0.98 & 1.65 & 3.97 & 0.40 & 15 & $\mathrm{R}$ \\
\hline 779 & NV & BELEW RANCH & SEDAN & 620706 & 2.45 & 1.28 & 4.09 & 0.41 & 5 & $\mathrm{R}$ \\
\hline 779 & NV & BELEW RANCH & SHASTA & 570818 & 0.32 & 1.43 & 7.00 & 0.70 & 3 & $\mathrm{R}$ \\
\hline 779 & NV & BELEW RANCH & SUGAR & 511119 & 4.00 & 1.40 & 2.00 & 0.20 & 4 & I \\
\hline 779 & NV & BELEW RANCH & TURK & 550307 & 8.60 & 1.40 & 11.08 & 1.11 & 4 & I \\
\hline 779 & NV & BELEW RANCH & UNCLE & 511129 & 2.44 & 1.40 & 3.85 & 0.38 & 4 & I \\
\hline 780 & NV & BELMONT & BOLTZMANN & 570528 & 15.70 & 1.13 & 5.31 & 0.53 & 12 & $\mathrm{R}$ \\
\hline 780 & NV & BELMONT & HOW & 520605 & 0.67 & 1.40 & 6.00 & 0.60 & 4 & 1 \\
\hline 780 & NV & BELMONT & PALANQUIN & 650414 & 0.25 & 1.00 & 9.00 & 0.90 & 1 & $\mathrm{R}$ \\
\hline 780 & NV & BELMONT & SCHOONER & 681208 & 0.14 & 1.00 & 5.00 & 0.75 & 1 & $\mathrm{R}$ \\
\hline 780 & NV & BELMONT & WHITNEY & 570923 & 0.76 & 1.00 & 9.60 & 1.44 & 1 & $\mathrm{R}$ \\
\hline 2013 & NV & BLAIR JUNCTION & FIZEAU & 570914 & 0.15 & 1.21 & 9.00 & 0.90 & 2 & $\mathrm{R}$ \\
\hline
\end{tabular}




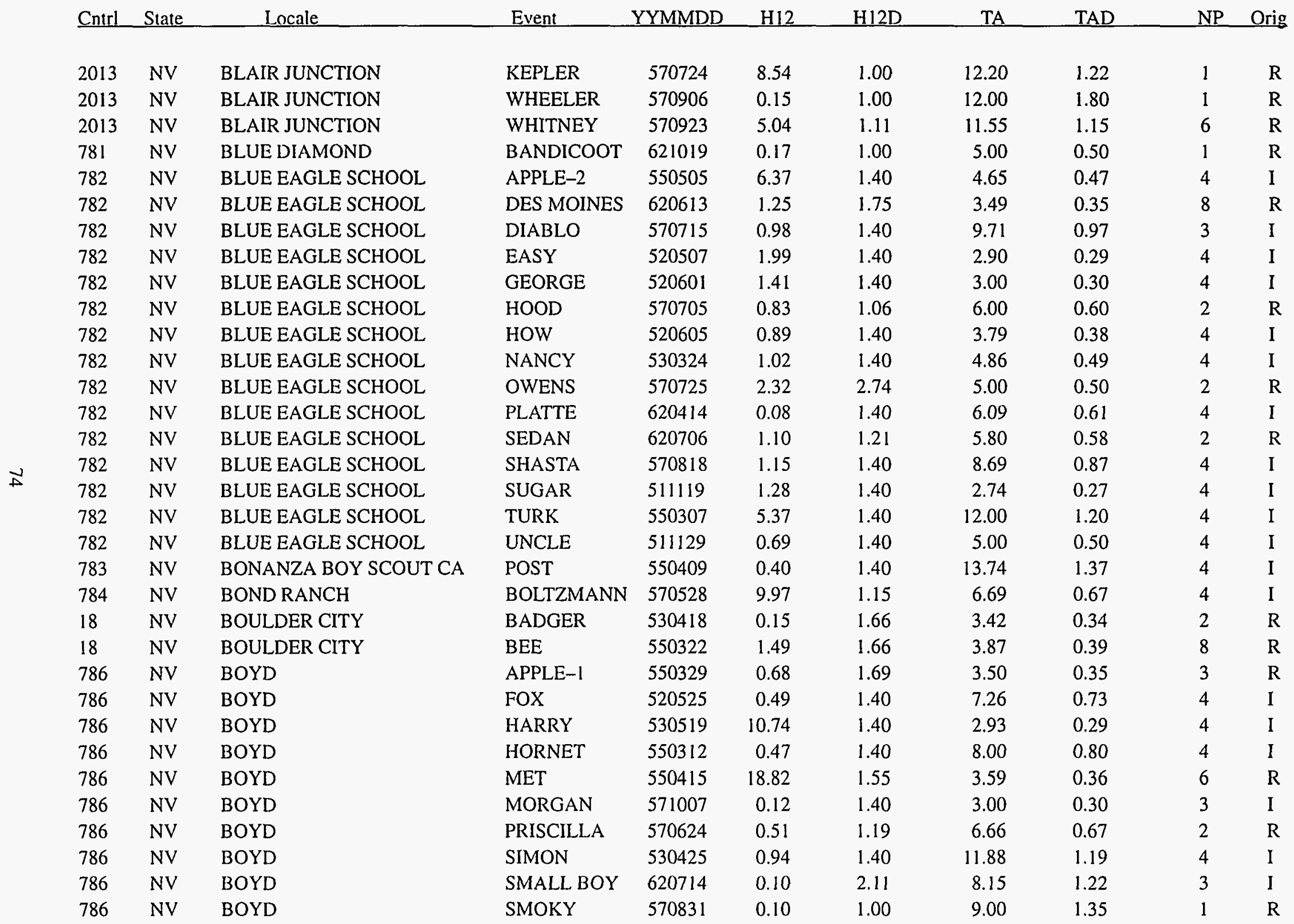




\begin{tabular}{|c|c|c|c|c|c|c|c|c|c|c|}
\hline Cntrl & State & Locale & Event & YYMMDD & $\mathrm{H} 12$ & $\mathrm{H} 12 \mathrm{D}$ & $\mathrm{TA}$ & TAD & NP & Orig \\
\hline 787 & NV & BRISTOL SILVER MINE & DIABLO & 570715 & 0.87 & 1.40 & 9.67 & 0.97 & 3 & I \\
\hline 787 & NV & BRISTOL SILVER MINE & EASY & 520507 & 2.15 & 1.40 & 2.00 & 0.20 & 4 & I \\
\hline 787 & NV & BRISTOL SILVER MINE & EDDY & 580919 & 0.06 & 1.40 & 6.72 & 0.67 & 4 & I \\
\hline 787 & NV & BRISTOL SILVER MINE & FOX & 520525 & 2.90 & 1.40 & 9.92 & 0.99 & 4 & I \\
\hline 787 & NV & BRISTOL SILVER MINE & HOOD & 570705 & 0.10 & 1.40 & 6.00 & 0.60 & 3 & I \\
\hline 787 & NV & BRISTOL SILVER MINE & NEWTON & 570916 & 0.10 & 1.40 & 3.56 & 0.36 & 4 & I \\
\hline 787 & NV & BRISTOL SILVER MINE & SMALL BOY & 620714 & 0.17 & 1.40 & 10.01 & 1.00 & 4 & I \\
\hline 787 & NV & BRISTOL SILVER MINE & TURK & 550307 & 0.42 & 1.40 & 13.09 & 1.31 & 4 & I \\
\hline 787 & NV & BRISTOL SILVER MINE & WILSON & 570618 & 0.50 & 1.40 & 14.00 & 2.10 & 4 & I \\
\hline 788 & NV & BUCKHORN RANCH & APPLE-1 & 550329 & 0.08 & 1.60 & 2.00 & 0.20 & 6 & $\mathrm{R}$ \\
\hline 788 & NV & BUCKHORN RANCH & DOG & 520501 & 0.10 & 1.39 & 3.00 & 0.45 & 3 & $\mathrm{R}$ \\
\hline 788 & NV & BUCKHORN RANCH & HARRY & 530519 & 13.43 & 1.00 & 1.93 & 0.19 & 1 & $\mathrm{R}$ \\
\hline 788 & NV & BUCKHORN RANCH & HORNET & 550312 & 0.71 & 1.40 & 5.60 & 0.56 & 4 & I \\
\hline 788 & NV & BUCKHORN RANCH & MET & 550415 & 15.15 & 1.80 & 3.00 & 0.30 & 7 & $\mathrm{R}$ \\
\hline 788 & NV & BUCKHORN RANCH & POST & 550409 & 0.40 & 1.40 & 10.00 & 1.00 & 3 & I \\
\hline 788 & NV & BUCKHORN RANCH & PRISCILLA & 570624 & 0.51 & 1.86 & 5.85 & 0.58 & 3 & $\mathrm{R}$ \\
\hline 788 & NV & BUCKHORN RANCH & SIMON & 530425 & 0.34 & 1.33 & 7.97 & 0.80 & 2 & $\mathrm{R}$ \\
\hline 788 & NV & BUCKHORN RANCH & SMALL BOY & 620714 & 1.74 & 1.27 & 4.67 & 0.47 & 5 & R \\
\hline 788 & NV & BUCKHORN RANCH & TESLA & 550301 & 0.55 & 1.00 & 5.08 & 0.51 & 1 & $\hat{R}$ \\
\hline 788 & NV & BUCKHORN RANCH & WILSON & 570618 & 0.50 & 1.16 & 23.00 & 3.45 & 3 & I \\
\hline 789 & NV & BUNKERVILLE & ANNIE & 530317 & 0.09 & 4.42 & 3.00 & 0.30 & 3 & I \\
\hline 789 & NV & BUNKERVILLE & ESS & 550323 & 0.13 & 1.00 & 8.43 & 0.84 & 1 & $\mathrm{R}$ \\
\hline 789 & NV & BUNKERVILLE & HARRY & 530519 & 1.71 & 1.82 & 2.47 & 0.25 & 6 & $\mathrm{R}$ \\
\hline 789 & NV & BUNKERVILLE & HORNET & 550312 & 0.50 & 1.09 & 8.22 & 0.82 & 4 & $\mathrm{R}$ \\
\hline 789 & NV & BUNKERVILLE & PRISCILLA & 570624 & 0.24 & 1.00 & 10.00 & 1.50 & 1 & $\mathrm{R}$ \\
\hline 789 & NV & BUNKERVILLE & SIMON & 530425 & 96.49 & 1.37 & 5.88 & 0.59 & 11 & $\mathrm{R}$ \\
\hline 789 & NV & BUNKERVILLE & SMOKY & 570831 & 3.33 & 1.00 & 6.47 & 0.65 & 1 & $\mathrm{R}$ \\
\hline 789 & NV & BUNKERVILLE & ZUCCHINI & 550515 & 2.17 & 1.38 & 3.34 & 0.33 & 4 & I \\
\hline 790 & NV & BUTLER RANCH & ANNIE & 530317 & 17.61 & 1.40 & 2.01 & 0.20 & 3 & I \\
\hline 790 & NV & BUTLER RANCH & ESS & 550323 & 0.99 & 1.40 & 5.00 & 0.50 & 4 & I \\
\hline 790 & NV & BUTLER RANCH & HARRY & 530519 & 74.37 & 1.40 & 1.40 & 0.14 & 4 & I \\
\hline 790 & NV & BUTLER RANCH & HORNET & 550312 & 0.76 & 1.27 & 5.55 & 0.55 & 3 & $\mathrm{R}$ \\
\hline 790 & NV & BUTLER RANCH & MET & 550415 & 0.58 & 1.00 & 2.00 & 0.20 & 1 & $\mathrm{R}$ \\
\hline
\end{tabular}




\begin{tabular}{|c|c|c|c|c|c|c|c|c|c|c|}
\hline Cntrl & State & Locale & Event & YYMMDD & $\mathrm{H} 12$ & $\mathrm{H} 12 \mathrm{D}$ & $\mathrm{TA}$ & TAD & $\mathrm{NP}$ & Orig \\
\hline 790 & NV & BUTLER RANCH & MORGAN & 571007 & 1.05 & 1.00 & 3.79 & 0.38 & 1 & $\mathrm{R}$ \\
\hline 790 & NV & BUTLER RANCH & PRISCILLA & 570624 & 0.29 & 1.00 & 4.20 & 0.42 & 1 & $\mathrm{R}$ \\
\hline 790 & NV & BUTLER RANCH & SIMON & 530425 & 19.20 & 1.40 & 2.99 & 0.30 & 4 & I \\
\hline 790 & NV & BUTLER RANCH & SMOKY & 570831 & 99.15 & 1.15 & 3.77 & 0.38 & 8 & $\mathrm{R}$ \\
\hline 790 & NV & BUTLER RANCH & TESLA & 550301 & 1.10 & 1.40 & 4.00 & 0.40 & 4 & I \\
\hline 790 & NV & BUTLER RANCH & TURK & 550307 & 0.91 & 1.40 & 9.06 & 0.91 & 4 & I \\
\hline 790 & NV & BUTLER RANCH & ZUCCHINI & 550515 & 1.46 & 1.40 & 1.69 & 0.17 & 4 & I \\
\hline 791 & NV & CACTUS SPRINGS & BADGER & 530418 & 0.08 & 2.30 & 1.58 & 0.16 & 5 & $\mathrm{R}$ \\
\hline 791 & NV & CACTUS SPRINGS & BANDICOOT & 621019 & 0.14 & 2.00 & 3.00 & 0.30 & 12 & $\mathrm{R}$ \\
\hline 791 & NV & CACTUS SPRINGS & CHARLIE & 520422 & 0.09 & 1.40 & 7.00 & 1.05 & 2 & $\mathrm{R}$ \\
\hline 791 & NV & CACTUS SPRINGS & CLIMAX & 530604 & 0.06 & 1.00 & 4.50 & 0.45 & 1 & $\mathrm{R}$ \\
\hline 791 & NV & CACTUS SPRINGS & PIKE & 640313 & 0.29 & 1.87 & 2.45 & 0.25 & 87 & $\mathrm{R}$ \\
\hline 791 & NV & CACTUS SPRINGS & POST & 550409 & 0.37 & 1.00 & 10.00 & 1.00 & 1 & $\mathrm{R}$ \\
\hline 791 & NV & CACTUS SPRINGS & SMOKY & 570831 & 0.26 & 1.00 & 9.00 & 1.35 & 1 & $\mathrm{R}$ \\
\hline 60 & NV & CALIENTE & APPLE-1 & 550329 & 2.54 & 1.44 & 4.00 & 0.40 & 22 & $\mathrm{R}$ \\
\hline 60 & NV & CALIENTE & FOX & 520525 & 4.74 & 1.14 & 8.09 & 0.81 & 18 & $\mathrm{R}$ \\
\hline 60 & NV & CALIENTE & HARRY & 530519 & 1.49 & 1.71 & 3.19 & 0.32 & 6 & $\mathrm{R}$ \\
\hline 60 & NV & CALIENTE & HIDALGO & 581005 & 0.08 & 1.40 & 14.45 & 1.45 & 4 & I \\
\hline 60 & NV & CALIENTE & HORNET & 550312 & 0.09 & 1.45 & 8.78 & 0.88 & 17 & $\mathrm{R}$ \\
\hline 60 & NV & CALIENTE & MET & 550415 & 3.14 & 1.43 & 4.00 & 0.40 & 19 & $\mathrm{R}$ \\
\hline 60 & NV & CALIENTE & SIMON & 530425 & 0.47 & 1.03 & 13.15 & 1.32 & 2 & $\mathrm{R}$ \\
\hline 60 & NV & CALIENTE & SMALL BOY & 620714 & 0.19 & 1.41 & 9.32 & 0.93 & 17 & $\mathrm{R}$ \\
\hline 793 & NV & CARP & HARRY & 530519 & 88.37 & 1.40 & 2.35 & 0.23 & 4 & I \\
\hline 793 & NV & CARP & HORNET & 550312 & 0.16 & 2.04 & 8.50 & 0.85 & 2 & $\mathrm{R}$ \\
\hline 793 & NV & CARP & PRISCILLA & 570624 & 2.82 & 1.32 & 5.91 & 0.59 & 12 & $\mathrm{R}$ \\
\hline 793 & NV & CARP & SIMON & 530425 & 2.38 & 1.40 & 8.99 & 0.90 & 4 & I \\
\hline 793 & NV & CARP & SMALL BOY & 620714 & 0.08 & 2.64 & 7.00 & 1.05 & 8 & $\mathrm{R}$ \\
\hline 793 & NV & CARP & SMOKY & 570831 & 1.06 & 1.64 & 7.00 & 1.05 & 10 & $\mathrm{R}$ \\
\hline 793 & NV & CARP & TESLA & 550301 & 0.54 & 1.80 & 6.14 & 0.61 & 2 & $\mathrm{R}$ \\
\hline 2007 & NV & CARRARA & COULOMB-B & 570906 & 0.30 & 1.40 & 5.40 & 0.54 & 4 & I \\
\hline 2007 & NV & CARRARA & QUAY & 581010 & 0.27 & 1.17 & 3.92 & 0.39 & 7 & $\mathrm{R}$ \\
\hline 2007 & NV & CARRARA & WILSON & 570618 & 0.50 & 1.40 & 13.00 & 1.95 & 3 & I \\
\hline 794 & NV & CASELTON MINE & APPLE-1 & 550329 & 0.52 & 1.19 & 4.00 & 0.40 & 4 & I \\
\hline
\end{tabular}




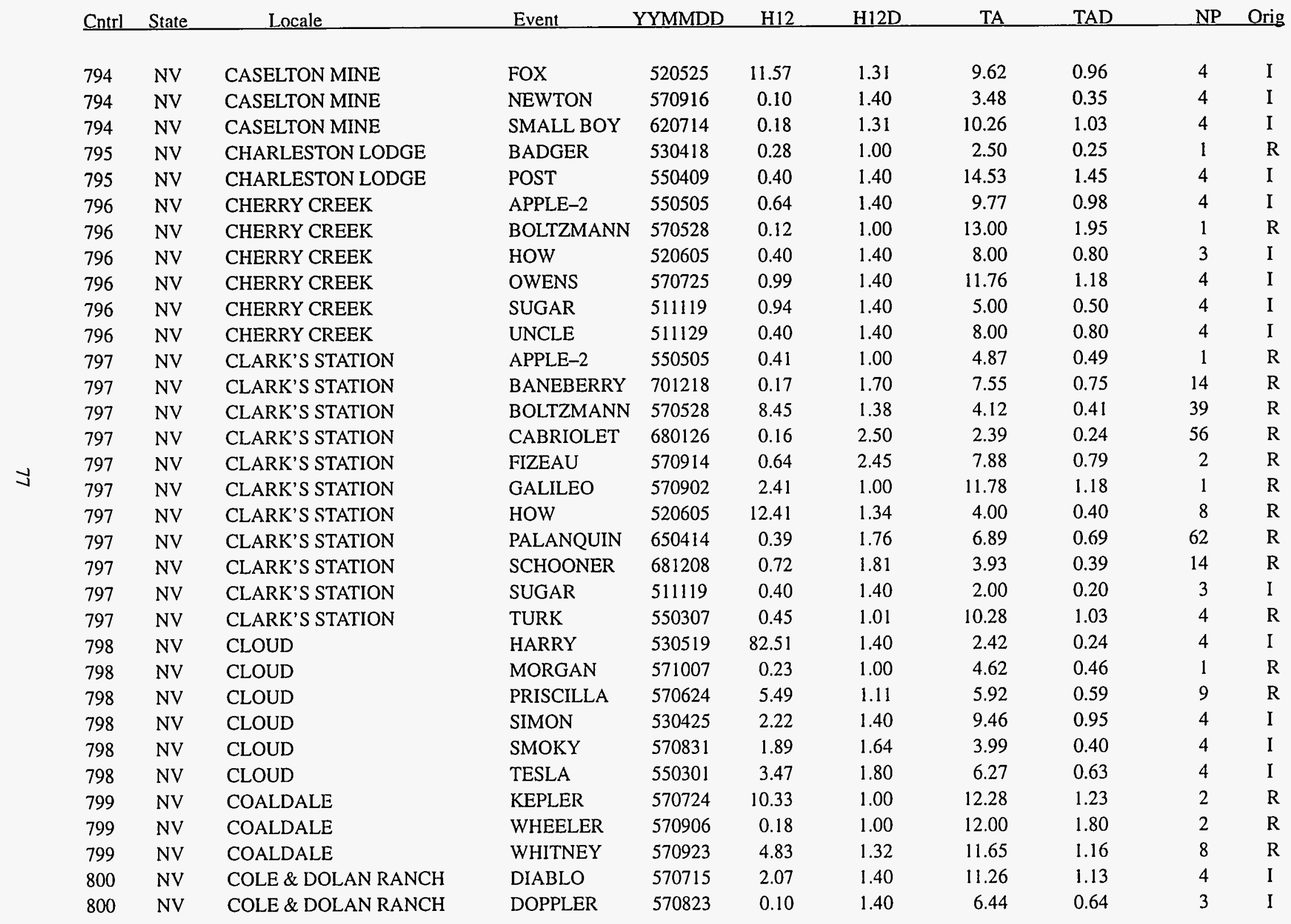




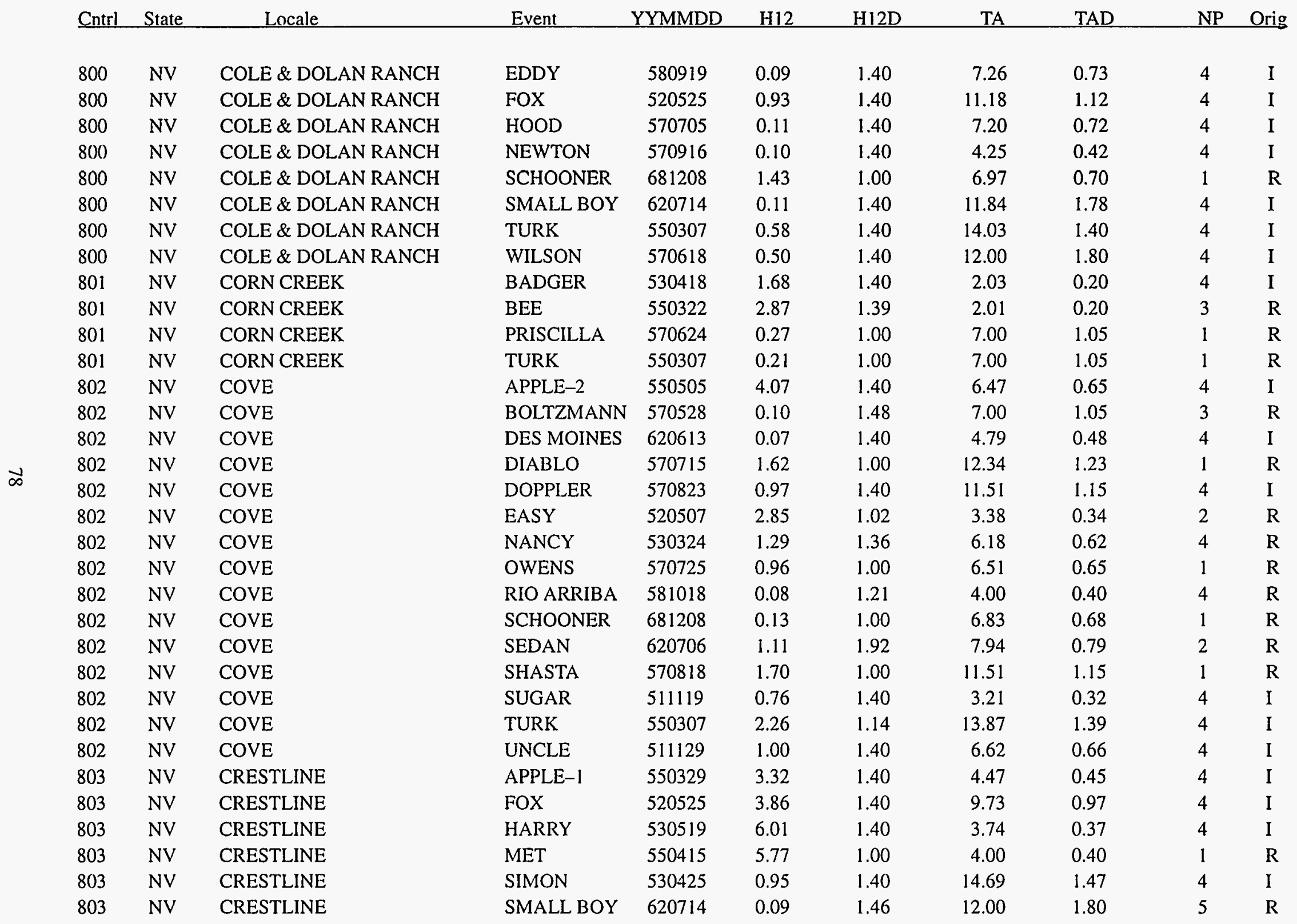




\begin{tabular}{|c|c|c|c|c|c|c|c|c|c|c|}
\hline Cntrl & State & Locale & Event & YYMMDD & $\mathrm{H} 12$ & $\mathrm{H} 12 \mathrm{D}$ & $\mathrm{TA}$ & TAD & NP & Orig \\
\hline 804 & NV & CRYSTAL & BADGER & 530418 & 34.36 & 1.98 & 2.47 & 0.25 & 39 & $\mathrm{R}$ \\
\hline 804 & NV & CRYSTAL & CLIMAX & 530604 & 2.32 & 1.99 & 5.27 & 0.53 & 7 & $\mathrm{R}$ \\
\hline 804 & NV & CRYSTAL & MOTH & 550222 & 0.29 & 1.72 & 3.50 & 0.52 & 3 & $\mathrm{R}$ \\
\hline 804 & NV & CRYSTAL & POST & 550409 & 0.07 & 1.00 & 18.00 & 1.80 & 1 & $\mathrm{R}$ \\
\hline 804 & NV & CRYSTAL & ZUCCHINI & 550515 & 1.55 & 1.32 & 3.17 & 0.32 & 9 & $\mathrm{R}$ \\
\hline 846 & NV & CRYSTAL SPRINGS & APPLE-1 & 550329 & 2.13 & 1.52 & 2.42 & 0.24 & 17 & $\mathrm{R}$ \\
\hline 846 & NV & CRYSTAL SPRINGS & DIABLO & 570715 & 0.89 & 1.80 & 5.87 & 0.59 & 16 & $\mathbf{R}$ \\
\hline 846 & NV & CRYSTAL SPRINGS & DOG & 520501 & 0.06 & 1.29 & 3.00 & 0.45 & 3 & $\mathrm{R}$ \\
\hline 846 & NV & CRYSTAL SPRINGS & FOX & 520525 & 4.35 & 2.13 & 5.59 & 0.56 & 12 & $\mathbf{R}$ \\
\hline 846 & NV & CRYSTAL SPRINGS & GALILEO & 570902 & 0.12 & 1.00 & 18.00 & 2.70 & 1 & $\mathrm{R}$ \\
\hline 846 & NV & CRYSTAL SPRINGS & HARRY & 530519 & 1.20 & 1.40 & 2.31 & 0.23 & 7 & $\mathrm{R}$ \\
\hline 846 & NV & CRYSTAL SPRINGS & HIDALGO & 581005 & 0.08 & 1.40 & 8.84 & 0.88 & 4 & I \\
\hline 846 & NV & CRYSTAL SPRINGS & MET & 550415 & 0.22 & 1.11 & 4.00 & 0.40 & 2 & $\mathrm{R}$ \\
\hline 846 & NV & CRYSTAL SPRINGS & PIN STRIPE & 660425 & 0.16 & 1.83 & 3.91 & 0.39 & 40 & $\mathrm{R}$ \\
\hline 846 & NV & CRYSTAL SPRINGS & TESLA & 550301 & 1.11 & 1.40 & 5.84 & 0.58 & 4 & I \\
\hline 846 & NV & CRYSTAL SPRINGS & UNCLE & 511129 & 0.43 & 1.40 & 2.81 & 0.28 & 3 & I \\
\hline 846 & NV & CRYSTAL SPRINGS & WILSON & 570618 & 0.62 & 1.37 & 12.98 & 1.95 & 4 & $\mathrm{R}$ \\
\hline 805 & NV & CURRANT & APPLE-2 & 550505 & 2.99 & 1.47 & 5.44 & 0.54 & 3 & $\mathrm{R}$ \\
\hline 805 & NV & CURRANT & BOLTZMANN & 570528 & 0.16 & 1.00 & 6.50 & 0.98 & 1 & $\mathrm{R}$ \\
\hline 805 & NV & CURRANT & DES MOINES & 620613 & 1.61 & 1.46 & 4.09 & 0.41 & 12 & $\mathrm{R}$ \\
\hline 805 & NV & CURRANT & DIABLO & 570715 & 1.41 & 1.26 & 11.00 & 1.10 & 6 & $\mathrm{R}$ \\
\hline 805 & NV & CURRANT & DOPPLER & 570823 & 0.16 & 1.40 & 10.48 & 1.05 & 4 & I \\
\hline 805 & NV & CURRANT & EASY & 520507 & 2.64 & 1.00 & 3.20 & 0.32 & 1 & $\mathrm{R}$ \\
\hline 805 & NV & CURRANT & GALILEO & 570902 & 0.30 & 1.00 & 24.00 & 3.60 & 1 & $\mathrm{R}$ \\
\hline 805 & NV & CURRANT & GEORGE & 520601 & 0.87 & 1.40 & 3.26 & 0.33 & 4 & I \\
\hline 805 & NV & CURRANT & GRABLE & 530525 & 0.12 & 1.56 & 4.00 & 0.40 & 4 & $\mathrm{R}$ \\
\hline 805 & NV & CURRANT & HOOD & 570705 & 0.16 & 1.00 & 10.00 & 1.50 & 1 & $\mathrm{R}$ \\
\hline 805 & NV & CURRANT & HOW & 520605 & 1.19 & 1.03 & 4.36 & 0.44 & 2 & $\mathrm{R}$ \\
\hline 805 & NV & CURRANT & NANCY & 530324 & 0.78 & 1.49 & 5.64 & 0.56 & 3 & $\mathrm{R}$ \\
\hline 805 & NV & CURRANT & OWENS & 570725 & 1.09 & 1.37 & 6.00 & 0.60 & 16 & $\mathrm{R}$ \\
\hline 805 & NV & CURRANT & PLATTE & 620414 & 0.09 & 1.40 & 7.91 & 0.79 & 4 & $I$ \\
\hline 805 & NV & CURRANT & SEDAN & 620706 & 1.14 & 1.22 & 6.91 & 0.69 & 8 & $\mathrm{R}$ \\
\hline 805 & NV & CURRANT & SHASTA & 570818 & 2.81 & 1.33 & 10.36 & 1.04 & 2 & $\mathrm{R}$ \\
\hline
\end{tabular}




\begin{tabular}{|c|c|c|c|c|c|c|c|c|c|c|}
\hline Cntrl & State & Locale & Event & YYMMDD & $\mathrm{H} 12$ & $\mathrm{H} 12 \mathrm{D}$ & $\mathrm{TA}$ & $\mathrm{TAD}$ & NP & Orig \\
\hline 805 & NV & CURRANT & SUGAR & 511119 & 1.00 & 1.40 & 3.00 & 0.30 & 4 & I \\
\hline 805 & NV & CURRANT & TURK & 550307 & 2.00 & 1.39 & 12.89 & 1.29 & 3 & $\mathrm{R}$ \\
\hline 805 & NV & CURRANT & UNCLE & 511129 & 0.60 & 1.40 & 6.00 & 0.60 & 4 & I \\
\hline 812 & NV & D-X RANCH & APPLE-2 & 550505 & 1.39 & 1.69 & 8.43 & 0.84 & 4 & I \\
\hline 812 & NV & D-X RANCH & DIABLO & 570715 & 3.54 & 1.16 & 14.90 & 1.49 & 4 & I \\
\hline 812 & NV & D-X RANCH & DOPPLER & 570823 & 0.37 & 1.40 & 12.72 & 1.27 & 4 & I \\
\hline 812 & NV & D-X RANCH & GRABLE & 530525 & 0.40 & 1.40 & 3.00 & 0.30 & 3 & I \\
\hline 812 & NV & D-X RANCH & HOOD & 570705 & 0.12 & 1.40 & 9.00 & 0.90 & 4 & I \\
\hline 812 & NV & D-X RANCH & NANCY & 530324 & 1.45 & 1.40 & 6.64 & 0.66 & 4 & I \\
\hline 812 & NV & D-X RANCH & OWENS & 570725 & 0.07 & 1.40 & 7.00 & 0.70 & 3 & I \\
\hline 812 & NV & D-X RANCH & SCHOONER & 681208 & 0.08 & 1.57 & 9.00 & 0.90 & 2 & $\mathrm{R}$ \\
\hline 812 & NV & D-X RANCH & UNCLE & 511129 & 0.40 & 1.40 & 7.49 & 0.75 & 4 & $\mathrm{I}$ \\
\hline 806 & NV & DELMUE & APPLE-1 & 550329 & 0.82 & 1.48 & 4.00 & 0.40 & 4 & I \\
\hline 806 & NV & DELMUE & FOX & 520525 & 10.64 & 1.40 & 9.79 & 0.98 & 4 & I \\
\hline 806 & NV & DELMUE & HARRY & 530519 & 1.28 & 1.68 & 4.01 & 0.40 & 4 & I \\
\hline 806 & NV & DELMUE & MET & 550415 & 0.80 & 2.36 & 4.89 & 0.49 & 4 & I \\
\hline 806 & NV & DELMUE & SMALL BOY & 620714 & 0.12 & 1.73 & 10.98 & 1.10 & 4 & I \\
\hline 957 & NV & DESERT GAME REFUGE & BADGER & 530418 & 1.74 & 1.40 & 2.03 & 0.20 & 4 & I \\
\hline 957 & NV & DESERT GAME REFUGE & $\mathrm{BEE}$ & 550322 & 2.44 & 1.05 & 2.01 & 0.20 & 2 & $\mathrm{R}$ \\
\hline 957 & NV & DESERT GAME REFUGE & PRISCILLA & 570624 & 0.27 & 1.00 & 7.00 & 1.05 & 1 & $\mathbf{R}$ \\
\hline 807 & NV & DESERT ROCK & POST & 550409 & 1.58 & 1.28 & 8.84 & 0.88 & 4 & $\mathrm{R}$ \\
\hline 808 & NV & DODGE CONSTRUCTION C & DIABLO & 570715 & 39.30 & 1.35 & 4.89 & 0.49 & 39 & $\mathbf{R}$ \\
\hline 808 & NV & DODGE CONSTRUCTION C & GALILEO & 570902 & 1.05 & 1.00 & 14.00 & 2.10 & 1 & $\mathbf{R}$ \\
\hline 808 & NV & DODGE CONSTRUCTION C & HOOD & 570705 & 0.63 & 1.19 & 2.00 & 0.20 & 19 & $\mathrm{R}$ \\
\hline 808 & NV & DODGE CONSTRUCTION C & OWENS & 570725 & 0.37 & 1.59 & 2.10 & 0.31 & 11 & $\mathrm{R}$ \\
\hline 808 & NV & DODGE CONSTRUCTION C & SHASTA & 570818 & 0.11 & 1.39 & 5.50 & 0.82 & 2 & $\mathrm{R}$ \\
\hline 809 & NV & DONAHUE RANCH & FOX & 520525 & 1.44 & 1.40 & 11.59 & 1.16 & 4 & I \\
\hline 809 & NV & DONAHUE RANCH & NEWTON & 570916 & 0.10 & 1.40 & 4.54 & 0.45 & 4 & $\mathrm{I}$ \\
\hline 809 & NV & DONAHUE RANCH & SCHOONER & 681208 & 0.06 & 1.40 & 7.51 & 0.75 & 4 & $I$ \\
\hline 809 & NV & DONAHUE RANCH & SMALL BOY & 620714 & 0.11 & 1.40 & 13.41 & 2.01 & 4 & 1 \\
\hline 809 & NV & DONAHUE RANCH & TURK & 550307 & 0.48 & 1.40 & 14.40 & 1.44 & 4 & I \\
\hline 809 & NV & DONAHUE RANCH & WILSON & 570618 & 0.50 & 1.40 & 15.00 & 2.25 & 4 & I \\
\hline 810 & NV & DRY LAKE & BADGER & 530418 & 8.49 & 2.83 & 2.58 & 0.26 & 25 & $\mathrm{R}$ \\
\hline
\end{tabular}




\begin{tabular}{|c|c|c|c|c|c|c|c|c|c|c|}
\hline Cntrl & State & Locale & Event & YYMMDD & $\mathrm{H} 12$ & $\mathrm{H} 12 \mathrm{D}$ & $\mathrm{TA}$ & TAD & NP & Orig \\
\hline 810 & NV & DRY LAKE & CLIMAX & 530604 & 0.83 & 1.99 & 5.63 & 0.56 & 6 & $\mathrm{R}$ \\
\hline 810 & NV & DRY LAKE & HORNET & 550312 & 0.12 & 1.40 & 6.00 & 0.60 & 1 & $\mathbf{R}$ \\
\hline 810 & NV & DRY LAKE & MOTH & 550222 & 5.34 & 2.03 & 3.50 & 0.52 & 14 & $\mathrm{R}$ \\
\hline 810 & $\mathrm{NV}$ & DRY LAKE & ZUCCHINI & 550515 & 1.43 & 1.48 & 3.30 & 0.33 & 10 & $\mathbf{R}$ \\
\hline 811 & NV & DUCKWATER & APPLE-2 & 550505 & 9.14 & 1.14 & 5.59 & 0.56 & 2 & $\mathrm{R}$ \\
\hline 811 & NV & DUCKWATER & DES MOINES & 620613 & 0.37 & 1.00 & 4.43 & 0.44 & 1 & $\mathrm{R}$ \\
\hline 811 & NV & DUCKWATER & GALILEO & 570902 & 0.88 & 1.00 & 23.00 & 3.45 & 1 & $\mathrm{R}$ \\
\hline 811 & NV & DUCKWATER & GEORGE & 520601 & 6.80 & 1.40 & 4.12 & 0.41 & 4 & I \\
\hline 811 & NV & DUCKWATER & HOW & 520605 & 1.32 & 1.40 & 5.00 & 0.50 & 4 & I \\
\hline 811 & NV & DUCKWATER & NANCY & 530324 & 0.52 & 1.40 & 6.34 & 0.63 & 4 & I \\
\hline 811 & NV & DUCKWATER & OWENS & 570725 & 0.57 & 1.00 & 7.00 & 0.70 & 1 & $\mathrm{R}$ \\
\hline 811 & NV & DUCKWATER & SEDAN & 620706 & 0.75 & 1.00 & 7.58 & 0.76 & 1 & $\mathrm{R}$ \\
\hline 811 & NV & DUCKWATER & SHASTA & 570818 & 3.84 & 1.00 & 11.00 & 1.10 & 1 & $\mathbf{R}$ \\
\hline 811 & NV & DUCKWATER & SUGAR & 511119 & 1.00 & 1.40 & 3.00 & 0.30 & 4 & I \\
\hline 811 & NV & DUCKWATER & TURK & 550307 & 1.40 & 1.40 & 12.92 & 1.29 & 4 & I \\
\hline 932 & NV & DYER & KEPLER & 570724 & 1.19 & 1.40 & 11.53 & 1.15 & 4 & I \\
\hline 932 & NV & DYER & WHITNEY & 570923 & 0.19 & 1.18 & 10.97 & 1.10 & 2 & $\mathbf{R}$ \\
\hline 110 & NV & EAST ELY & APPLE-2 & 550505 & 3.12 & 1.63 & 7.46 & 0.75 & 9 & $\mathrm{R}$ \\
\hline 110 & NV & EAST ELY & DIABLO & 570715 & 1.16 & 1.77 & 14.27 & 1.43 & 20 & $\mathrm{R}$ \\
\hline 110 & NV & EAST ELY & DOPPLER & 570823 & 0.48 & 1.20 & 13.63 & 1.36 & 4 & $\mathrm{R}$ \\
\hline 110 & NV & EAST ELY & EASY & 520507 & 4.65 & 1.12 & 3.94 & 0.39 & 4 & $\mathrm{R}$ \\
\hline 110 & NV & EAST ELY & NANCY & 530324 & 1.00 & 1.41 & 6.85 & 0.69 & 19 & $\mathrm{R}$ \\
\hline 110 & NV & EAST ELY & OWENS & 570725 & 0.34 & 1.47 & 7.80 & 0.78 & 5 & $\mathrm{R}$ \\
\hline 110 & NV & EAST ELY & SEDAN & 620706 & 0.68 & 1.11 & 10.00 & 1.50 & 7 & $\mathrm{R}$ \\
\hline 110 & NV & EAST ELY & SHASTA & 570818 & 3.07 & 1.55 & 12.83 & 1.28 & 11 & $\mathrm{R}$ \\
\hline 110 & NV & EAST ELY & SUGAR & 511119 & 0.44 & 1.40 & 4.00 & 0.40 & 4 & I \\
\hline 110 & NV & EAST ELY & TURK & 550307 & 1.37 & 1.65 & 14.55 & 1.46 & 9 & $\mathrm{R}$ \\
\hline 110 & NV & EAST ELY & UNCLE & 511129 & 0.53 & 1.40 & 7.00 & 0.70 & 4 & I \\
\hline 739 & NV & EL DORADO & APPLE-2 & 550505 & 1.81 & 1.17 & 6.65 & 0.66 & 3 & $\mathrm{R}$ \\
\hline 739 & NV & EL DORADO & BOLTZMANN & 570528 & 0.59 & 1.92 & 8.08 & 0.81 & 2 & $\mathrm{R}$ \\
\hline 739 & NV & EL DORADO & DES MOINES & 620613 & 0.07 & 1.00 & 5.50 & 0.55 & 1 & $\mathrm{R}$ \\
\hline 739 & NV & EL DORADO & GEORGE & 520601 & 0.73 & 1.00 & 6.00 & 0.60 & 1 & $\mathbf{R}$ \\
\hline 739 & NV & EL DORADO & HOW & 520605 & 1.13 & 1.40 & 7.00 & 0.70 & 4 & I \\
\hline
\end{tabular}




\begin{tabular}{|c|c|c|c|c|c|c|c|c|c|c|}
\hline Cntr] & State & Locale & Event & YYMMDD & $\mathrm{H} 12$ & $\mathrm{H} 12 \mathrm{D}$ & $\mathrm{TA}$ & $\mathrm{TAD}$ & NP & Orig \\
\hline 739 & NV & EL DORADO & OWENS & 570725 & 1.06 & 1.05 & 8.10 & 0.81 & 2 & $\mathrm{R}$ \\
\hline 739 & NV & EL DORADO & SEDAN & 620706 & 0.40 & 1.17 & 9.50 & 1.42 & 2 & $\mathrm{R}$ \\
\hline 739 & NV & EL DORADO & SHASTA & 570818 & 4.76 & 1.11 & 12.64 & 1.26 & 4 & $\mathrm{R}$ \\
\hline 739 & NV & EL DORADO & SUGAR & 511119 & 1.14 & 1.40 & 4.00 & 0.40 & 4 & $\mathrm{I}$ \\
\hline 739 & NV & EL DORADO & TURK & 550307 & 0.06 & 1.00 & 14.00 & 1.40 & 1 & $\mathrm{R}$ \\
\hline 746 & NV & ELDRIDGE RANCH (MT.W & APPLE-2 & 550505 & 3.43 & 1.69 & 8.69 & 0.87 & 2 & $\mathrm{R}$ \\
\hline 746 & NV & ELDRIDGE RANCH (MT.W & DIABLO & 570715 & 2.38 & 1.00 & 15.04 & 1.50 & 2 & $\mathbf{R}$ \\
\hline 746 & NV & ELDRIDGE RANCH (MT.W & GRABLE & 530525 & 0.40 & 1.40 & 3.00 & 0.30 & 3 & I \\
\hline 746 & NV & ELDRIDGE RANCH (MT.W & HOOD & 570705 & 0.13 & 1.40 & 9.00 & 0.90 & 4 & I \\
\hline 746 & NV & ELDRIDGE RANCH (MT.W & NANCY & 530324 & 1.92 & 1.40 & 6.56 & 0.66 & 4 & I \\
\hline 746 & NV & ELDRIDGE RANCH (MT.W & NEWTON & 570916 & 0.10 & 1.40 & 6.00 & 0.60 & 3 & I \\
\hline 746 & NV & ELDRIDGE RANCH (MT.W & SCHOONER & 681208 & 0.06 & 1.32 & 9.00 & 0.90 & 2 & $\mathrm{R}$ \\
\hline 746 & NV & ELDRIDGE RANCH (MT.W & TURK & 550307 & 0.52 & 1.40 & 15.49 & 1.55 & 3 & I \\
\hline 746 & NV & ELDRIDGE RANCH (MT.W & UNCLE & 511129 & 0.40 & 1.40 & 7.76 & 0.78 & 4 & I \\
\hline 741 & NV & ELDRIDGE RANCH (NO. & APPLE-2 & 550505 & 0.56 & 1.40 & 7.66 & 0.77 & 4 & I \\
\hline 741 & NV & ELDRIDGE RANCH (NO. & GEORGE & 520601 & 3.78 & 1.40 & 6.28 & 0.63 & 4 & I \\
\hline 741 & NV & ELDRIDGE RANCH (NO. & HOW & 520605 & 1.00 & 1.40 & 7.34 & 0.73 & 4 & I \\
\hline 741 & NV & ELDRIDGE RANCH (NO. & OWENS & 570725 & 1.26 & 1.40 & 9.00 & 0.90 & 4 & I \\
\hline 741 & NV & ELDRIDGE RANCH (NO. & SHASTA & 570818 & 5.00 & 1.40 & 13.45 & 1.35 & 4 & $\mathrm{I}$ \\
\hline 741 & NV & ELDRIDGE RANCH (NO. & SUGAR & 511119 & 1.04 & 1.40 & 5.00 & 0.50 & 4 & I \\
\hline 773 & NV & ELGIN & APPLE-1 & 550329 & 0.39 & 1.84 & 3.68 & 0.37 & 3 & $\mathrm{R}$ \\
\hline 773 & NV & ELGIN & HARRY & 530519 & 21.61 & 1.40 & 2.76 & 0.28 & 4 & I \\
\hline 773 & NV & ELGIN & HORNET & 550312 & 0.41 & 1.40 & 7.91 & 0.79 & 3 & $\mathrm{I}$ \\
\hline 773 & NV & ELGIN & MET & 550415 & 47.47 & 1.32 & 3.00 & 0.30 & 5 & $\mathrm{R}$ \\
\hline 773 & NV & ELGIN & PRISCILLA & 570624 & 1.20 & 1.62 & 6.35 & 0.64 & 12 & $\mathrm{R}$ \\
\hline 773 & NV & ELGIN & SIMON & 530425 & 1.00 & 1.40 & 11.25 & 1.13 & 4 & I \\
\hline 773 & NV & ELGIN & SMALL BOY & 620714 & 0.08 & 2.11 & 8.09 & 1.21 & 14 & $\mathrm{R}$ \\
\hline 773 & NV & ELGIN & SMOKY & 570831 & 0.14 & 1.00 & 9.00 & 1.35 & 1 & $\mathrm{R}$ \\
\hline 773 & NV & ELGIN & TESLA & 550301 & 0.62 & 1.40 & 6.86 & 0.69 & 4 & I \\
\hline 31 & NV & ELKO & GEORGE & 520601 & 1.55 & 1.27 & 9.50 & 1.42 & 4 & $\mathrm{R}$ \\
\hline 111 & NV & ELY & APPLE-2 & 550505 & 3.12 & 1.63 & 7.43 & 0.74 & 9 & $\mathrm{R}$ \\
\hline 111 & NV & ELY & DIABLO & 570715 & 1.22 & 1.70 & 14.24 & 1.42 & 23 & $\mathrm{R}$ \\
\hline 111 & NV & ELY & DOPPLER & 570823 & 0.48 & 1.20 & 13.62 & 1.36 & 4 & $\mathrm{R}$ \\
\hline
\end{tabular}




\begin{tabular}{|c|c|c|c|c|c|c|c|c|c|c|}
\hline Cntrl & State & Locale & Event & YYMMDD & $\mathrm{H} 12$ & $\mathrm{H} 12 \mathrm{D}$ & TA & TAD & NP & Orig \\
\hline 813 & NV & FALLINI RANCH & LEA & 581013 & 0.34 & 1.00 & 10.78 & 1.08 & 2 & $\mathrm{R}$ \\
\hline 813 & NV & FALLINI RANCH & NANCY & 530324 & 0.20 & 1.00 & 4.25 & 0.43 & 1 & $\mathbf{R}$ \\
\hline 813 & NV & FALLINI RANCH & OWENS & 570725 & 0.60 & 1.00 & 4.18 & 0.42 & 1 & $\mathbf{R}$ \\
\hline 813 & NV & FALLINI RANCH & SCHOONER & 681208 & 0.13 & 2.20 & 4.03 & 0.40 & 170 & $\mathrm{R}$ \\
\hline 813 & NV & FALLINI RANCH & SEDAN & 620706 & 1.04 & 1.74 & 4.68 & 0.47 & 18 & $\mathrm{R}$ \\
\hline 813 & NV & FALLINI RANCH & SHASTA & 570818 & 14.94 & 1.25 & 5.34 & 0.53 & 11 & $\mathrm{R}$ \\
\hline 813 & NV & FALLINI RANCH & SUGAR & 511119 & 1.09 & 1.40 & 2.00 & 0.20 & 4 & I \\
\hline 813 & NV & FALLINI RANCH & TURK & 550307 & 6.73 & 1.40 & 10.43 & 1.04 & 4 & I \\
\hline 813 & NV & FALLINI RANCH & UNCLE & 511129 & 0.40 & 1.40 & 3.21 & 0.32 & 3 & I \\
\hline 813 & NV & FALLINI RANCH & WHITNEY & 570923 & 0.08 & 1.40 & 11.00 & 1.65 & 2 & $\mathrm{R}$ \\
\hline 5 & NV & FALLON & BOLTZMANN & 570528 & 3.69 & 1.32 & 11.78 & 1.18 & 10 & $\mathrm{R}$ \\
\hline 5 & NV & FALLON & KEPLER & 570724 & 1.45 & 1.40 & 15.00 & 1.50 & 4 & $\mathrm{I}$ \\
\hline 958 & NV & FARRIER & ANNIE & 530317 & 4.32 & 1.40 & 2.73 & 0.27 & 4 & I \\
\hline 958 & NV & FARRIER & ESS & 550323 & 1.03 & 1.40 & 6.27 & 0.63 & 4 & $\mathrm{I}$ \\
\hline 958 & NV & FARRIER & HARRY & 530519 & 4.76 & 1.40 & 1.71 & 0.17 & 4 & $I$ \\
\hline 958 & NV & FARRIER & HORNET & 550312 & 4.06 & 1.40 & 6.79 & 0.68 & 4 & I \\
\hline 958 & NV & FARRIER & SIMON & 530425 & 17.81 & 1.40 & 3.91 & 0.39 & 4 & I \\
\hline 958 & NV & FARRIER & SMALL BOY & 620714 & 0.11 & 1.00 & 5.00 & 0.50 & 1 & $\mathrm{R}$ \\
\hline 958 & NV & FARRIER & SMOKY & 570831 & 2.13 & 1.21 & 5.34 & 0.53 & 8 & $\mathrm{R}$ \\
\hline 958 & NV & FARRIER & TURK & 550307 & 0.42 & 1.40 & 9.91 & 0.99 & 3 & I \\
\hline 958 & NV & FARRIER & ZUCCHINI & 550515 & 4.34 & 1.40 & 2.34 & 0.23 & 4 & I \\
\hline 594 & NV & FERNLEY & BOLTZMANN & 570528 & 3.13 & 1.00 & 13.00 & 1.30 & 1 & $\mathrm{R}$ \\
\hline 814 & NV & FISH CREEK RANCH & APPLE-2 & 550505 & 2.96 & 1.17 & 6.25 & 0.63 & 2 & $\mathrm{R}$ \\
\hline 814 & NV & FISH CREEK RANCH & BOLTZMANN & 570528 & 0.77 & 1.40 & 7.43 & 0.74 & 4 & I \\
\hline 814 & NV & FISH CREEK RANCH & GEORGE & 520601 & 2.19 & 1.40 & 5.85 & 0.58 & 4 & I \\
\hline 814 & NV & FISH CREEK RANCH & HOW & 520605 & 1.46 & 1.40 & 6.40 & 0.64 & 4 & I \\
\hline 814 & NV & FISH CREEK RANCH & LEA & 581013 & 0.07 & 1.40 & 13.00 & 1.30 & 4 & I \\
\hline 814 & NV & FISH CREEK RANCH & OWENS & 570725 & 1.05 & 1.40 & 7.28 & 0.73 & 4 & I \\
\hline 814 & NV & FISH CREEK RANCH & SEDAN & 620706 & 0.51 & 1.40 & 8.00 & 0.80 & 3 & I \\
\hline 814 & NV & FISH CREEK RANCH & SHASTA & 570818 & 3.43 & 1.39 & 11.83 & 1.18 & 3 & $\mathrm{R}$ \\
\hline 814 & NV & FISH CREEK RANCH & SUGAR & 511119 & 1.23 & 1.40 & 4.00 & 0.40 & 4 & I \\
\hline 83 & NV & GABBS & BOLTZMANN & 570528 & 1.31 & 1.40 & 7.38 & 0.74 & 4 & I \\
\hline 83 & NV & GABBS & KEPLER & 570724 & 5.17 & 1.40 & 15.00 & 1.50 & 4 & I \\
\hline
\end{tabular}




\begin{tabular}{|c|c|c|c|c|c|c|c|c|c|c|}
\hline Cntrl & State & Locale & Event & YYMMDD & $\mathrm{H} 12$ & $\mathrm{H} 12 \mathrm{D}$ & $\mathrm{TA}$ & TAD & NP & Orig \\
\hline 83 & NV & GABBS & WHITNEY & 570923 & 1.01 & 1.40 & 16.55 & 1.65 & 4 & $I$ \\
\hline 815 & NV & GALT & ANNIE & 530317 & 13.96 & 1.40 & 2.13 & 0.21 & 4 & I \\
\hline 815 & NV & GALT & ESS & 550323 & 0.69 & 1.40 & 6.78 & 0.68 & 3 & I \\
\hline 815 & $\mathrm{NV}$ & GALT & HARRY & 530519 & 76.37 & 1.40 & 2.01 & 0.20 & 4 & I \\
\hline 815 & NV & GALT & HORNET & 550312 & 0.68 & 1.40 & 7.05 & 0.71 & 4 & I \\
\hline 815 & NV & GALT & PRISCILLA & 570624 & 1.28 & 1.40 & 5.78 & 0.58 & 4 & I \\
\hline 815 & NV & GALT & SIMON & 530425 & 3.53 & 1.40 & 6.56 & 0.66 & 4 & I \\
\hline 815 & NV & GALT & SMOKY & 570831 & 83.93 & 1.38 & 4.34 & 0.43 & 11 & $\mathrm{R}$ \\
\hline 815 & NV & GALT & TESLA & 550301 & 0.91 & 1.80 & 5.35 & 0.53 & 2 & $\mathrm{R}$ \\
\hline 815 & NV & GALT & TURK & 550307 & 0.46 & 1.40 & 10.12 & 1.01 & 3 & I \\
\hline 816 & NV & GARNET & BADGER & 530418 & 2.93 & 1.62 & 2.86 & 0.29 & 12 & $\mathrm{R}$ \\
\hline 816 & NV & GARNET & CLIMAX & 530604 & 0.43 & 2.13 & 5.91 & 0.59 & 3 & $\mathrm{R}$ \\
\hline 816 & NV & GARNET & MOTH & 550222 & 2.56 & 2.75 & 2.00 & 0.20 & 12 & $\mathrm{R}$ \\
\hline 816 & NV & GARNET & ZUCCHINI & 550515 & 1.55 & 1.18 & 3.41 & 0.34 & 7 & $\mathrm{R}$ \\
\hline 817 & NV & GEYSER MAINTENANCE S & APPLE-2 & 550505 & 1.12 & 1.18 & 7.50 & 0.75 & 3 & $\mathrm{R}$ \\
\hline 817 & NV & GEYSER MAINTENANCE S & DIABLO & 570715 & 4.24 & 1.63 & 12.10 & 1.21 & 2 & $\mathrm{R}$ \\
\hline 817 & NV & GEYSER MAINTENANCE S & DOPPLER & 570823 & 0.43 & 1.67 & 8.76 & 0.88 & 3 & $\mathrm{R}$ \\
\hline 817 & NV & GEYSER MAINTENANCE S & EASY & 520507 & 7.89 & 1.00 & 2.72 & 0.27 & 1 & $\mathrm{R}$ \\
\hline 817 & NV & GEYSER MAINTENANCE S & GRABLE & 530525 & 0.31 & 1.16 & 2.14 & 0.21 & 2 & $\mathrm{R}$ \\
\hline 817 & NV & GEYSER MAINTENANCE S & HOOD & 570705 & 0.32 & 1.12 & 7.81 & 0.78 & 5 & $\mathrm{R}$ \\
\hline 817 & NV & GEYSER MAINTENANCE S & NANCY & 530324 & 7.83 & 1.61 & 5.44 & 0.54 & 8 & $\mathrm{R}$ \\
\hline 817 & NV & GEYSER MAINTENANCE S & SCHOONER & 681208 & 0.54 & 1.61 & 7.08 & 0.71 & 222 & $\mathrm{R}$ \\
\hline 817 & NV & GEYSER MAINTENANCE S & SEDAN & 620706 & 0.52 & 1.40 & 7.63 & 0.76 & 3 & I \\
\hline 817 & NV & GEYSER MAINTENANCE S & SMALL BOY & 620714 & 0.08 & 1.38 & 12.00 & 1.80 & 3 & $\mathrm{R}$ \\
\hline 817 & NV & GEYSER MAINTENANCE S & TURK & 550307 & 1.00 & 1.40 & 14.10 & 1.41 & 4 & I \\
\hline 817 & NV & GEYSER MAINTENANCE S & UNCLE & 511129 & 0.40 & 1.40 & 6.14 & 0.61 & 4 & I \\
\hline 818 & NV & GEYSER RANCH & APPLE-2 & 550505 & 0.92 & 1.00 & 7.50 & 0.75 & 2 & $\mathrm{R}$ \\
\hline 818 & NV & GEYSER RANCH & DIABLO & 570715 & 5.35 & 1.61 & 12.16 & 1.22 & 4 & $\mathrm{R}$ \\
\hline 818 & NV & GEYSER RANCH & DOPPLER & 570823 & 0.88 & 1.67 & 8.85 & 0.89 & 4 & I \\
\hline 818 & NV & GEYSER RANCH & EASY & 520507 & 7.89 & 1.00 & 2.80 & 0.28 & 1 & $\mathrm{R}$ \\
\hline 818 & NV & GEYSER RANCH & GRABLE & 530525 & 0.28 & 1.20 & 2.25 & 0.23 & 3 & $\mathrm{R}$ \\
\hline 818 & NV & GEYSER RANCH & HOOD & 570705 & 0.26 & 1.00 & 7.80 & 0.78 & 1 & $\mathrm{R}$ \\
\hline 818 & NV & GEYSER RANCH & NANCY & 530324 & 17.72 & 1.24 & 5.48 & 0.55 & 8 & $\mathrm{R}$ \\
\hline
\end{tabular}




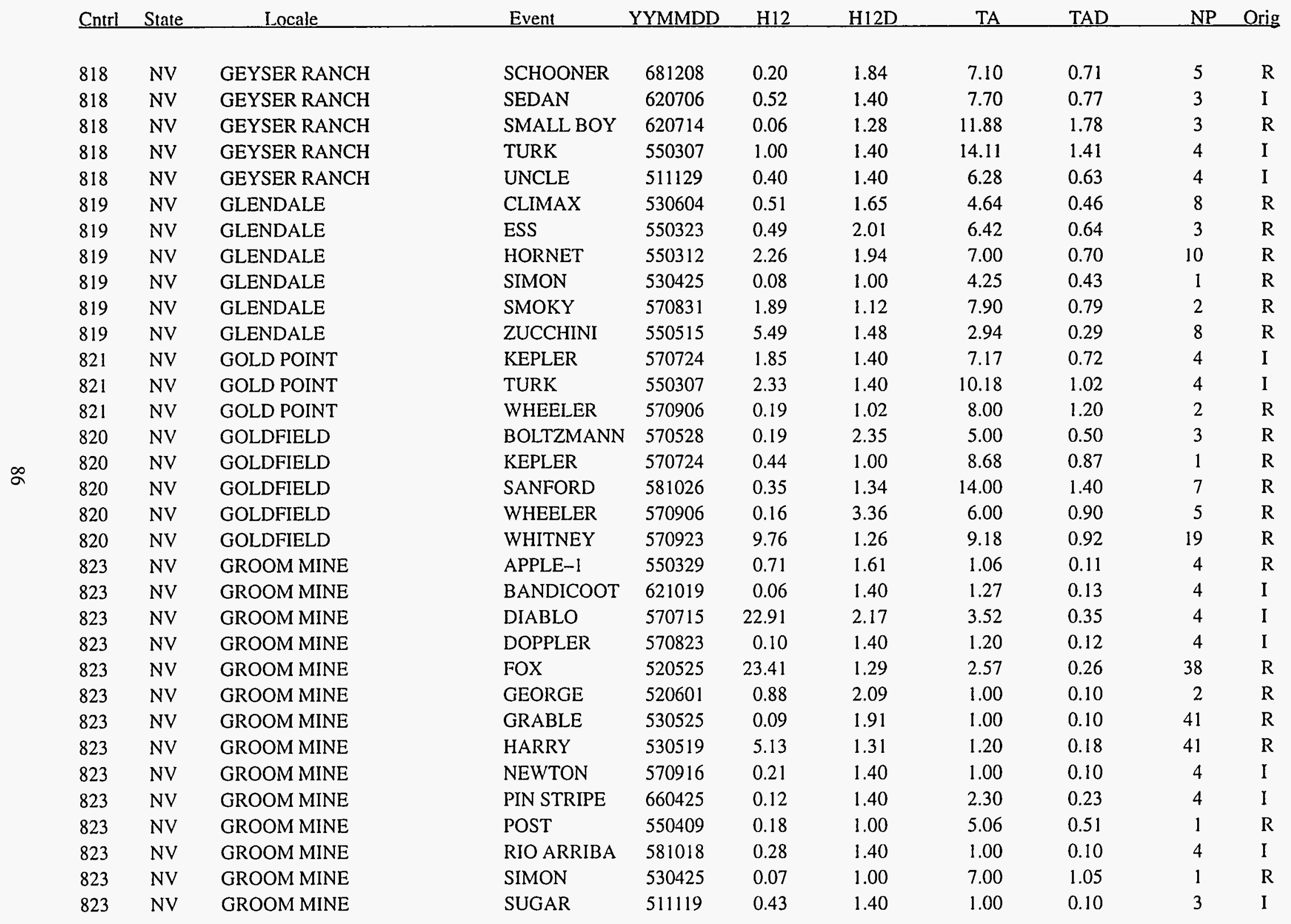




\begin{tabular}{|c|c|c|c|c|c|c|c|c|c|c|}
\hline Cntrl & State & Locale & Event & YYMMDD & $\mathrm{H} 12$ & $\mathrm{H} 12 \mathrm{D}$ & TA & TAD & NP & Orig \\
\hline 823 & NV & GROOM MINE & TESLA & 550301 & 0.41 & 1.40 & 3.05 & 0.30 & 4 & I \\
\hline 823 & NV & GROOM MINE & UNCLE & 511129 & 1.16 & 1.40 & 1.00 & 0.10 & 4 & I \\
\hline 823 & NV & GROOM MINE & WHITNEY & 570923 & 1.76 & 1.40 & 1.34 & 0.13 & 3 & I \\
\hline 823 & NV & GROOM MINE & WILSON & 570618 & 0.35 & 1.35 & 5.37 & 0.54 & 12 & $\mathrm{R}$ \\
\hline 823 & NV & GROOM MINE & WRANGELL & 581022 & 0.07 & 1.40 & 4.04 & 0.40 & 4 & I \\
\hline 824 & NV & GUBLER RANCH & APPLE-2 & 550505 & 1.37 & 1.38 & 6.43 & 0.64 & 4 & I \\
\hline 824 & NV & GUBLER RANCH & DIABLO & 570715 & 5.25 & 1.05 & 11.76 & 1.18 & 2 & $\mathrm{R}$ \\
\hline 824 & NV & GUBLER RANCH & DOPPLER & 570823 & 0.95 & 1.40 & 10.11 & 1.01 & 4 & I \\
\hline 824 & NV & GUBLER RANCH & EASY & 520507 & 4.75 & 1.40 & 3.00 & 0.30 & 4 & I \\
\hline 824 & NV & GUBLER RANCH & GRABLE & 530525 & 0.67 & 1.70 & 3.00 & 0.30 & 4 & I \\
\hline 824 & $\mathrm{NV}$ & GUBLER RANCH & HOOD & 570705 & 0.11 & 1.23 & 7.12 & 0.71 & 2 & $\mathrm{R}$ \\
\hline 824 & NV & GUBLER RANCH & NANCY & 530324 & 2.31 & 1.32 & 5.67 & 0.57 & 2 & $\mathrm{R}$ \\
\hline 824 & NV & GUBLER RANCH & OWENS & 570725 & 0.19 & 1.30 & 6.00 & 0.60 & 4 & I \\
\hline 824 & NV & GUBLER RANCH & SCHOONER & 681208 & 0.68 & 1.00 & 6.62 & 0.66 & 1 & $\mathrm{R}$ \\
\hline 824 & NV & GUBLER RANCH & SEDAN & 620706 & 1.10 & 1.00 & 7.45 & 0.75 & 1 & $\mathrm{R}$ \\
\hline 824 & NV & GUBLER RANCH & TURK & 550307 & 1.64 & 1.40 & 13.65 & 1.37 & 4 & I \\
\hline 824 & NV & GUBLER RANCH & UNCLE & 511129 & 1.00 & 1.40 & 6.00 & 0.60 & 4 & I \\
\hline 74 & NV & HAWTHORNE & BOLTZMANN & 570528 & 3.74 & 1.00 & 9.00 & 0.90 & 1 & $\mathrm{R}$ \\
\hline 74 & NV & HAWTHORNE & KEPLER & 570724 & 1.95 & 1.40 & 15.00 & 1.50 & 4 & I \\
\hline 74 & NV & HAWTHORNE & WHITNEY & 570923 & 1.00 & 1.40 & 15.25 & 1.52 & 4 & I \\
\hline 10 & NV & HENDERSON & BADGER & 530418 & 0.59 & 1.80 & 3.00 & 0.30 & 4 & I \\
\hline 10 & NV & HENDERSON & BEE & 550322 & 0.07 & 2.03 & 3.54 & 0.35 & 6 & $\mathrm{R}$ \\
\hline 825 & NV & HIKO & APPLE-1 & 550329 & 0.88 & 1.47 & 2.81 & 0.28 & 6 & $\mathrm{R}$ \\
\hline 825 & NV & HIKO & BANDICOOT & 621019 & 0.07 & 1.00 & 3.00 & 0.30 & 1 & $\mathrm{R}$ \\
\hline 825 & NV & HIKO & DIABLO & 570715 & 1.04 & 1.22 & 6.09 & 0.61 & 5 & $\mathrm{R}$ \\
\hline 825 & NV & HIKO & EASY & 520507 & 0.74 & 1.40 & 0.76 & 0.08 & 4 & I \\
\hline 825 & NV & HIKO & FOX & 520525 & 16.83 & 1.00 & 6.02 & 0.60 & 1 & $\mathrm{R}$ \\
\hline 825 & NV & HIKO & HARRY & 530519 & 2.16 & 1.23 & 2.49 & 0.25 & 4 & $\mathrm{R}$ \\
\hline 825 & NV & HIKO & MET & 550415 & 0.09 & 1.46 & 4.50 & 0.45 & 2 & $\mathrm{R}$ \\
\hline 825 & NV & HIKO & PIN STRIPE & 660425 & 0.15 & 1.64 & 4.19 & 0.42 & 74 & $\mathrm{R}$ \\
\hline 825 & NV & HIKO & TESLA & 550301 & 0.78 & 1.40 & 6.00 & 0.60 & 4 & I \\
\hline 825 & NV & HIKO & TURK & 550307 & 0.44 & 1.40 & 10.31 & 1.03 & 3 & 1 \\
\hline 825 & NV & HIKO & UNCLE & 511129 & 0.48 & 1.40 & 3.00 & 0.30 & 4 & I \\
\hline
\end{tabular}




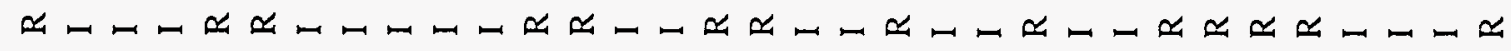

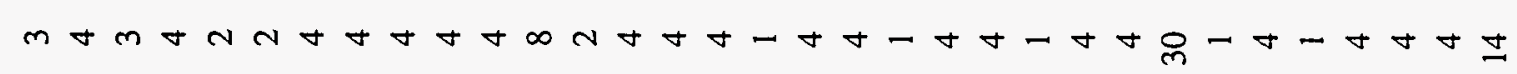

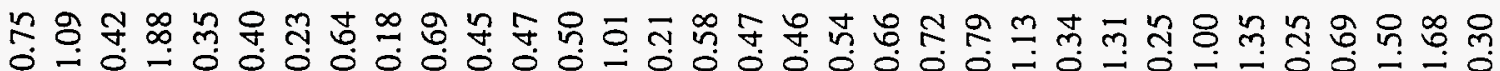

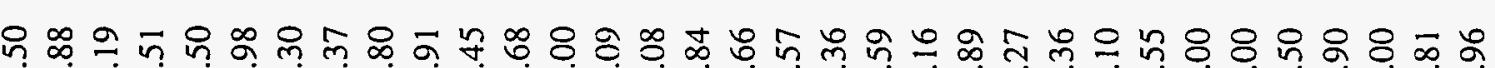

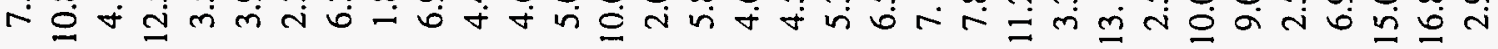

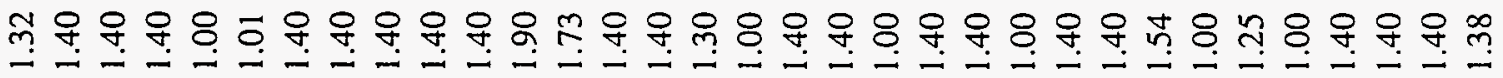

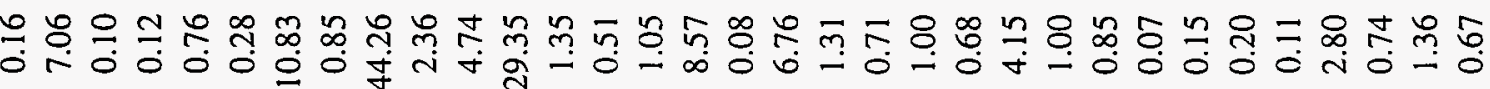

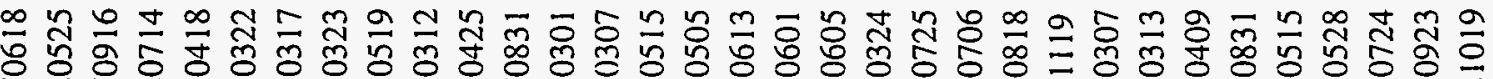

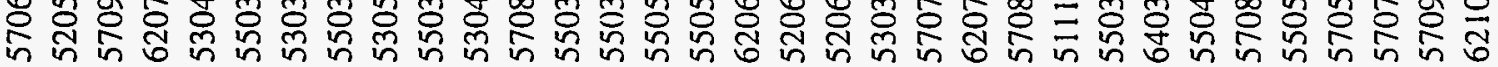

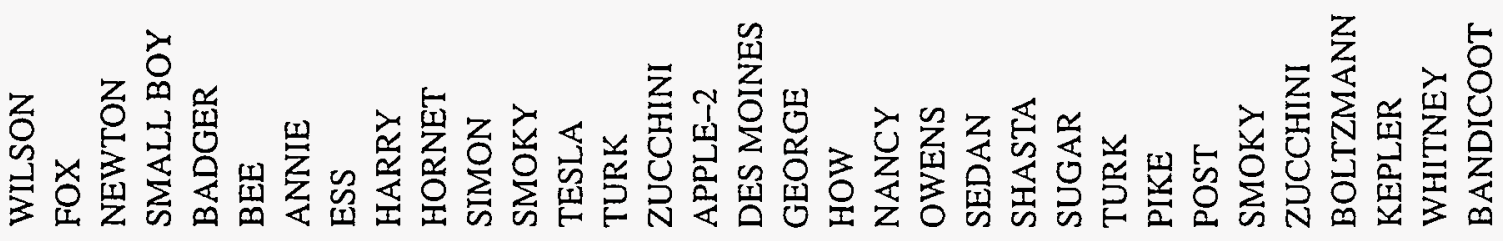

军界军

革交交

$\$ 2$

$\because \approx$ थ $\sum \sum$

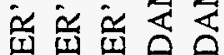

Z

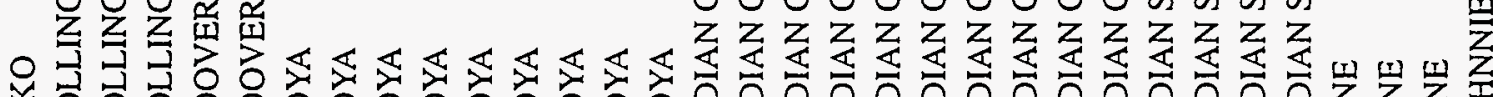

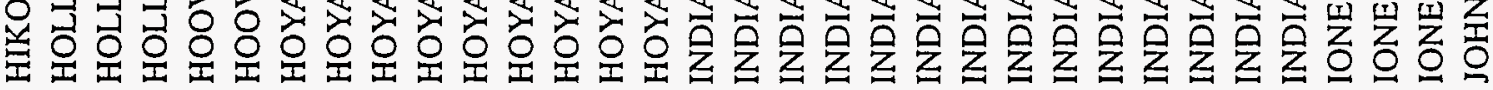

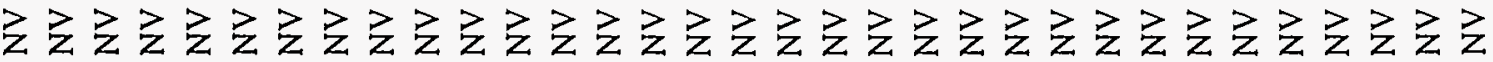

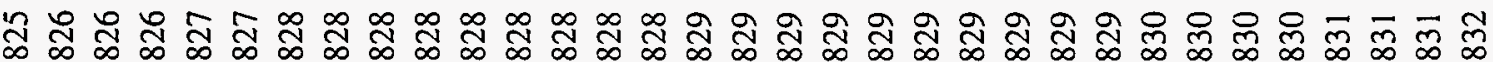




\begin{tabular}{|c|c|c|c|c|c|c|c|c|c|c|}
\hline Cntrl & State & Locale & Event & YYMMDD & $\mathrm{H} 12$ & $\mathrm{H} 12 \mathrm{D}$ & $\mathrm{TA}$ & $\mathrm{TAD}$ & NP & Orig \\
\hline 832 & NV & JOHNNIE & POST & 550409 & 0.32 & 1.40 & 11.61 & 1.16 & 3 & I \\
\hline 832 & NV & JOHNNIE & RAY & 530411 & 0.06 & 1.00 & 2.25 & 0.22 & 1 & $\mathbf{R}$ \\
\hline 2011 & NV & JOHNNIES WATER & APPLE-1 & 550329 & 0.41 & 1.40 & 1.71 & 0.17 & 4 & I \\
\hline 2011 & NV & JOHNNIES WATER & APPLE-2 & 550505 & 39.81 & 1.40 & 1.23 & 0.12 & 4 & I \\
\hline 2011 & $\mathrm{NV}$ & JOHNNIES WATER & BANDICOOT & 621019 & 0.48 & 1.40 & 1.42 & 0.14 & 4 & I \\
\hline 2011 & NV & JOHNNIES WATER & BANEBERRY & 701218 & 0.74 & 1.40 & 6.00 & 0.60 & 4 & 1 \\
\hline 2011 & NV & JOHNNIES WATER & BOLTZMANN & 570528 & 2.80 & 1.40 & 1.13 & 0.11 & 3 & I \\
\hline 2011 & NV & JOHNNIES WATER & DES MOINES & 620613 & 32.44 & 1.40 & 0.50 & 0.05 & 4 & I \\
\hline 2011 & NV & JOHNNIES WATER & DLABLO* & 570715 & & & deleted)- & & & \\
\hline 2011 & NV & JOHNNIES WATER & EASY & 520507 & 9.47 & 1.40 & 0.63 & 0.06 & 4 & I \\
\hline 2011 & NV & JOHNNIES WATER & EEL & 620519 & 2.27 & 1.40 & 1.00 & 0.10 & 4 & $\mathrm{I}$ \\
\hline 2011 & NV & JOHNNIES WATER & FOX & 520525 & 9.25 & 1.00 & 4.38 & 0.44 & 1 & $\mathrm{R}$ \\
\hline 2011 & NV & JOHNNIES WATER & FRANKLIN P & 570830 & 0.12 & 1.40 & 1.65 & 0.17 & 3 & I \\
\hline 2011 & NV & JOHNNIES WATER & GEORGE & 520601 & 9.41 & 1.40 & 1.53 & 0.15 & 4 & I \\
\hline 2011 & NV & JOHNNIES WATER & GRABLE & 530525 & 0.51 & 1.40 & 1.00 & 0.10 & 3 & I \\
\hline 2011 & NV & JOHNNIES WATER & HOOD & 570705 & 0.12 & 1.40 & 1.00 & 0.10 & 4 & I \\
\hline 2011 & $\mathrm{NV}$ & JOHNNIES WATER & HOW & 520605 & 6.84 & 1.40 & 1.00 & 0.10 & 4 & I \\
\hline 2011 & NV & JOHNNIES WATER & LEA & 581013 & 0.16 & 1.40 & 3.34 & 0.33 & 4 & I \\
\hline 2011 & NV & JOHNNIES WATER & NANCY & 530324 & 14.78 & 1.40 & 1.26 & 0.13 & 4 & I \\
\hline 2011 & NV & JOHNNIES WATER & OWENS & 570725 & 0.21 & 1.40 & 1.64 & 0.16 & 4 & $\mathrm{I}$ \\
\hline 2011 & NV & JOHNNIES WATER & PLATTE & 620414 & 0.98 & 1.40 & 1.05 & 0.10 & 4 & $\mathrm{I}$ \\
\hline 2011 & NV & JOHNNIES WATER & POST & 550409 & 0.08 & 1.40 & 4.42 & 0.44 & 3 & $\mathrm{I}$ \\
\hline 2011 & NV & JOHNNIES WATER & RIO ARRIBA & 581018 & 0.07 & 1.40 & 1.00 & 0.10 & 4 & I \\
\hline 2011 & NV & JOHNNIES WATER & SEDAN & 620706 & 3.77 & 1.40 & 1.00 & 0.10 & 4 & I \\
\hline 2011 & $\mathrm{NV}$ & JOHNNIES WATER & SHASTA & 570818 & 15.30 & 1.13 & 1.83 & 0.18 & 3 & $\mathrm{R}$ \\
\hline 2011 & NV & JOHNNIES WATER & STOKES & 570807 & 0.10 & 1.40 & 0.92 & 0.09 & 4 & I \\
\hline 2011 & NV & JOHNNIES WATER & SUGAR & 511119 & 8.11 & 1.40 & 1.00 & 0.10 & 4 & I \\
\hline 2011 & NV & JOHNNIES WATER & TURK & 550307 & 13.84 & 1.40 & 6.51 & 0.65 & 4 & I \\
\hline 2011 & $\mathrm{NV}$ & JOHNNIES WATER & UNCLE & 511129 & 10.27 & 1.40 & 1.00 & 0.10 & 4 & I \\
\hline 2011 & NV & JOHNNIES WATER & VESTA & 581017 & 0.08 & 1.40 & 2.46 & 0.25 & 4 & I \\
\hline 2011 & NV & JOHNNIES WATER & WHITNEY & 570923 & 7.98 & 1.40 & 2.73 & 0.27 & 4 & I \\
\hline 2011 & NV & JOHNNIES WATER & WILSON & 570618 & 0.53 & 1.40 & 7.00 & 1.05 & 4 & I \\
\hline 833 & $\mathrm{NV}$ & KIMBERLY & APPLE-2 & 550505 & 4.00 & 1.63 & 7.18 & 0.72 & 4 & I \\
\hline
\end{tabular}




\begin{tabular}{|c|c|c|c|c|c|c|c|c|c|c|}
\hline Cntrl & State & Locale & Event & YYMMDD & $\mathrm{H} 12$ & $\mathrm{H} 12 \mathrm{D}$ & $\mathrm{TA}$ & $\mathrm{TAD}$ & NP & Orig \\
\hline 833 & $\mathrm{NV}$ & KIMBERLY & DIABLO & 570715 & 0.76 & 1.26 & 13.97 & 1.40 & 6 & $\mathrm{R}$ \\
\hline 833 & $N V$ & KIMBERLY & DOPPLER & 570823 & 0.82 & 1.46 & 13.68 & 1.37 & 4 & I \\
\hline 833 & NV & KIMBERLY & EASY & 520507 & 4.01 & 1.12 & 4.00 & 0.40 & 3 & I \\
\hline 833 & NV & KIMBERLY & NANCY & 530324 & 0.54 & 1.49 & 6.90 & 0.69 & 4 & I \\
\hline 833 & NV & KIMBERLY & OWENS & 570725 & 0.33 & 1.00 & 8.00 & 0.80 & 1 & $\mathrm{R}$ \\
\hline 833 & NV & KIMBERLY & SHASTA & 570818 & 1.58 & 1.52 & 12.85 & 1.28 & 4 & $I$ \\
\hline 833 & NV & KIMBERLY & SUGAR & 511119 & 0.74 & 1.40 & 4.00 & 0.40 & 4 & $\mathrm{I}$ \\
\hline 833 & $\mathrm{NV}$ & KIMBERLY & TURK & 550307 & 1.04 & 1.80 & 14.32 & 1.43 & 4 & I \\
\hline 833 & NV & KIMBERLY & UNCLE & 511129 & 0.45 & 1.40 & 7.00 & 0.70 & 4 & $\mathrm{I}$ \\
\hline 834 & NV & KYLE & APPLE-1 & 550329 & 0.20 & 1.84 & 4.00 & 0.40 & 4 & I \\
\hline 834 & NV & KYLE & HARRY & 530519 & 30.57 & 1.40 & 2.78 & 0.28 & 4 & I \\
\hline 834 & NV & KYLE & MET & 550415 & 1.91 & 3.11 & 3.00 & 0.30 & 6 & $\mathrm{R}$ \\
\hline 834 & NV & KYLE & MORGAN & 571007 & 0.56 & 1.40 & 3.30 & 0.33 & 4 & I \\
\hline 834 & NV & KYLE & PRISCILLA & 570624 & 2.45 & 1.04 & 6.25 & 0.62 & 4 & $\mathrm{R}$ \\
\hline 834 & NV & KYLE & SIMON & 530425 & 1.07 & 1.40 & 11.45 & 1.14 & 4 & I \\
\hline 834 & NV & KYLE & SMALL BOY & 620714 & 0.15 & 1.00 & 8.00 & 1.20 & 1 & $\mathrm{R}$ \\
\hline 834 & NV & KYLE & SMOKY & 570831 & 0.10 & 1.00 & 9.00 & 1.35 & 1 & $\mathrm{R}$ \\
\hline 834 & NV & KYLE & TESLA & 550301 & 0.79 & 1.40 & 7.10 & 0.71 & 4 & I \\
\hline 835 & NV & LABOARD RANCH & BOLTZMANN & 570528 & 8.93 & 1.40 & 7.15 & 0.72 & 4 & I \\
\hline 45 & NV & LAGES STATION & OWENS & 570725 & 0.87 & 1.40 & 13.00 & 1.30 & 4 & I \\
\hline 836 & NV & LAKE MEAD BASE & BADGER & 530418 & 0.78 & 1.43 & 3.22 & 0.32 & 4 & I \\
\hline 836 & NV & LAKE MEAD BASE & $\mathrm{BEE}$ & 550322 & 0.45 & 1.43 & 3.89 & 0.39 & 3 & I \\
\hline 837 & NV & LANE CITY & APPLE-2 & 550505 & 3.95 & 1.63 & 7.39 & 0.74 & 4 & $I$ \\
\hline 837 & NV & LANE CITY & DIABLO & 570715 & 1.48 & 1.00 & 14.29 & 1.43 & 2 & $\mathrm{R}$ \\
\hline 837 & NV & LANE CITY & DOPPLER & 570823 & 1.78 & 1.66 & 13.92 & 1.39 & 2 & $\mathrm{R}$ \\
\hline 837 & NV & LANE CITY & EASY & 520507 & 4.01 & 1.12 & 3.99 & 0.40 & 4 & I \\
\hline 837 & NV & LANE CITY & NANCY & 530324 & 0.53 & 1.45 & 6.92 & 0.69 & 4 & I \\
\hline 837 & NV & LANE CITY & OWENS & 570725 & 0.49 & 1.58 & 7.97 & 0.80 & 4 & I \\
\hline 837 & NV & LANE CITY & SEDAN & 620706 & 0.65 & 1.00 & 10.00 & 1.50 & 1 & $\mathrm{R}$ \\
\hline 837 & NV & LANE CITY & SHASTA & 570818 & 1.45 & 1.54 & 12.96 & 1.30 & 4 & I \\
\hline 837 & NV & LANE CITY & SUGAR & 511119 & 0.53 & 1.40 & 4.00 & 0.40 & 4 & I \\
\hline 837 & $\mathrm{NV}$ & LANE CITY & TURK & 550307 & 1.00 & 1.73 & 14.56 & 1.46 & 4 & I \\
\hline 837 & $\mathrm{NV}$ & LANE CITY & UNCLE & 511129 & 0.49 & 1.40 & 7.00 & 0.70 & 4 & I \\
\hline
\end{tabular}




\begin{tabular}{|c|c|c|c|c|c|c|c|c|c|c|}
\hline Cntrl & State & Locale & Event & YYMMDD & $\mathrm{H} 12$ & $\mathrm{H} 12 \mathrm{D}$ & $\mathrm{TA}$ & TAD & NP & Orig \\
\hline 12 & NV & LAS VEGAS (JUNCTION & APPLE-1 & 550329 & 0.33 & 1.40 & 18.00 & 2.70 & 1 & $\mathrm{X}$ \\
\hline 12 & NV & LAS VEGAS (JUNCTION & BADGER & 530418 & 0.09 & 3.44 & 2.91 & 0.29 & 20 & $\mathrm{R}$ \\
\hline 12 & NV & LAS VEGAS (JUNCTION & BANDICOOT & 621019 & 0.08 & 1.00 & 5.00 & 0.75 & 1 & $\mathrm{R}$ \\
\hline 12 & NV & LAS VEGAS (JUNCTION & $\mathrm{BEE}$ & 550322 & 0.58 & 2.79 & 2.93 & 0.29 & 57 & $\mathrm{R}$ \\
\hline 12 & NV & LAS VEGAS (JUNCTION & HORNET* & 550312 & 0.47 & 1.00 & 5.50 & 0.55 & 1 & $R$ \\
\hline 12 & NV & LAS VEGAS (JUNCTION & POST & 550409 & 0.12 & 1.40 & 18.00 & 2.70 & 1 & $\mathrm{X}$ \\
\hline 12 & NV & LAS VEGAS (JUNCTION & SANFORD & 581026 & 0.20 & 1.40 & 24.00 & 3.60 & 1 & $\mathrm{X}$ \\
\hline 12 & NV & LAS VEGAS (JUNCTION & SOCORRO & 581022 & 0.19 & 1.40 & 24.00 & 3.60 & 1 & $\mathrm{X}$ \\
\hline 838 & NV & LATHROP WELLS & BANDICOOT & 621019 & 0.17 & 2.82 & 2.50 & 0.25 & 22 & $\mathrm{R}$ \\
\hline 838 & NV & LATHROP WELLS & POST & 550409 & 0.66 & 1.00 & 9.81 & 0.98 & 1 & $\mathrm{R}$ \\
\hline 838 & NV & LATHROP WELLS & QUAY & 581010 & 0.06 & 1.50 & 3.06 & 0.31 & 10 & $\mathrm{R}$ \\
\hline 838 & NV & LATHROP WELLS & SIMON & 530425 & 0.10 & 1.40 & 5.02 & 0.50 & 4 & I \\
\hline 838 & NV & LATHROP WELLS & WHITNEY & 570923 & 0.40 & 1.00 & 10.00 & 1.50 & 1 & $\mathrm{R}$ \\
\hline 838 & NV & LATHROP WELLS & WILSON & 570618 & 0.41 & 1.02 & 12.00 & 1.80 & 3 & $\mathrm{R}$ \\
\hline 839 & NV & LEHMAN CAVES & APPLE-2 & 550505 & 1.01 & 1.40 & 8.67 & 0.87 & 4 & I \\
\hline 839 & NV & LEHMAN CAVES & DIABLO & 570715 & 4.81 & 1.18 & 14.59 & 1.46 & 4 & I \\
\hline 839 & NV & LEHMAN CAVES & DOPPLER & 570823 & 0.11 & 1.40 & 11.18 & 1.12 & 4 & I \\
\hline 839 & NV & LEHMAN CAVES & HOOD & 570705 & 0.42 & 1.40 & 8.95 & 0.89 & 4 & I \\
\hline 839 & NV & LEHMAN CAVES & NANCY & 530324 & 5.97 & 1.40 & 6.14 & 0.61 & 4 & I \\
\hline 839 & $\mathrm{NV}$ & LEHMAN CAVES & NEWTON & 570916 & 0.10 & 1.40 & 5.74 & 0.57 & 4 & I \\
\hline 839 & NV & LEHMAN CAVES & TURK & 550307 & 0.95 & 1.40 & 15.34 & 1.53 & 4 & $\mathrm{I}$ \\
\hline 839 & NV & LEHMAN CAVES & UNCLE & 511129 & 0.40 & 1.40 & 7.11 & 0.71 & 4 & $I$ \\
\hline 840 & $\mathrm{NV}$ & LEITH & HARRY & 530519 & 51.32 & 1.40 & 2.63 & 0.26 & 4 & I \\
\hline 840 & NV & LEITH & MORGAN & 571007 & 0.10 & 1.00 & 3.89 & 0.39 & 1 & $\mathrm{R}$ \\
\hline 840 & NV & LEITH & PRISCILLA & 570624 & 2.87 & 1.00 & 5.96 & 0.60 & 2 & $\mathrm{R}$ \\
\hline 840 & NV & LEITH & SIMON & 530425 & 1.42 & 1.40 & 10.75 & 1.08 & 4 & I \\
\hline 840 & NV & LEITH & SMALL BOY & 620714 & 0.22 & 1.47 & 8.00 & 1.20 & 2 & $\mathrm{R}$ \\
\hline 840 & NV & LEITH & SMOKY & 570831 & 0.38 & 2.41 & 9.00 & 1.35 & 2 & $\mathrm{R}$ \\
\hline 840 & NV & LEITH & TESLA & 550301 & 1.73 & 1.40 & 6.81 & 0.68 & 4 & I \\
\hline 841 & NV & LIDA & KEPLER & 570724 & 3.35 & 1.01 & 8.00 & 0.80 & 2 & $\mathrm{R}$ \\
\hline 841 & NV & LIDA & WHEELER & 570906 & 0.13 & 1.56 & 9.00 & 1.35 & 2 & $\mathrm{R}$ \\
\hline 841 & NV & LIDA & WHITNEY & 570923 & 2.18 & 1.40 & 9.00 & 1.35 & 3 & $\mathrm{R}$ \\
\hline 842 & NV & LIDA JUNCTION & GALILEO & 570902 & 0.09 & 1.40 & 17.00 & 2.55 & 3 & $\mathrm{R}$ \\
\hline
\end{tabular}




\begin{tabular}{|c|c|c|c|c|c|c|c|c|c|c|}
\hline Cntrl & State & Locale & Event & YYMMDD & $\mathrm{H} 12$ & $\mathrm{H} 12 \mathrm{D}$ & $\mathrm{TA}$ & TAD & $\mathrm{NP}$ & Orig \\
\hline 842 & NV & LIDA JUNCTION & KEPLER & 570724 & 9.59 & 1.13 & 6.84 & 0.68 & 3 & $\mathrm{R}$ \\
\hline 842 & NV & LIDA JUNCTION & WHEELER & 570906 & 0.13 & 1.83 & 7.00 & 1.05 & 9 & $\mathbf{R}$ \\
\hline 842 & NV & LIDA JUNCTION & WHITNEY & 570923 & 0.61 & 2.48 & 7.98 & 0.80 & 8 & $\mathbf{R}$ \\
\hline 843 & NV & LINCOLN MINE & APPLE-1 & 550329 & 0.15 & 1.35 & 2.07 & 0.21 & 13 & $\mathrm{R}$ \\
\hline 843 & NV & LINCOLN MINE & APPLE-2 & 550505 & 0.15 & 2.60 & 2.00 & 0.20 & 4 & $\mathrm{R}$ \\
\hline 843 & NV & LINCOLN MINE & DIABLO & 570715 & 12.03 & 1.80 & 5.08 & 0.51 & 44 & $\mathrm{R}$ \\
\hline 843 & NV & LINCOLN MINE & EASY & 520507 & 11.89 & 1.50 & 0.75 & 0.07 & 103 & $\mathrm{R}$ \\
\hline 843 & NV & LINCOLN MINE & FOX & 520525 & 1.01 & 1.21 & 5.72 & 0.57 & 4 & $\mathrm{R}$ \\
\hline 843 & NV & LINCOLN MINE & GRABLE & 530525 & 0.41 & 1.49 & 1.00 & 0.10 & 37 & $\mathrm{R}$ \\
\hline 843 & NV & LINCOLN MINE & HOOD & 570705 & 0.47 & 1.56 & 2.00 & 0.20 & 17 & $\mathrm{R}$ \\
\hline 843 & NV & LINCOLN MINE & $\mathrm{HOW}^{*}$ & 520605 & & & deleted) & & & \\
\hline 843 & NV & LINCOLN MINE & NANCY & 530324 & 28.80 & 1.56 & 1.75 & 0.17 & 120 & $\mathrm{R}$ \\
\hline 843 & NV & LINCOLN MINE & POST & 550409 & 0.08 & 1.85 & 11.00 & 1.10 & 5 & $\mathrm{R}$ \\
\hline 843 & NV & LINCOLN MINE & SHASTA & 570818 & 0.18 & 1.37 & 10.00 & 1.50 & 2 & $\mathrm{R}$ \\
\hline 843 & NV & LINCOLN MINE & TURK & 550307 & 0.72 & 1.32 & 9.10 & 0.91 & 9 & $\mathrm{R}$ \\
\hline 843 & NV & LINCOLN MINE & UNCLE & 511129 & 10.71 & 1.40 & 2.00 & 0.20 & 4 & I \\
\hline 844 & NV & LOCKES & APPLE-2 & 550505 & 13.71 & 1.08 & 4.87 & 0.49 & 7 & $\mathrm{R}$ \\
\hline 844 & NV & LOCKES & BOLTZMANN & 570528 & 0.17 & 1.00 & 6.00 & 0.90 & 1 & $\mathrm{R}$ \\
\hline 844 & NV & LOCKES & DES MOINES & 620613 & 0.45 & 1.21 & 3.46 & 0.35 & 3 & $\mathrm{R}$ \\
\hline 844 & NV & LOCKES & DIABLO & 570715 & 0.80 & 2.07 & 10.00 & 1.00 & 2 & $\mathrm{R}$ \\
\hline 844 & NV & LOCKES & GALILEO & 570902 & 1.59 & 1.00 & 20.00 & 3.00 & 2 & $\mathrm{R}$ \\
\hline 844 & NV & LOCKES & GEORGE & 520601 & 9.62 & 1.53 & 3.17 & 0.32 & 4 & $\mathrm{R}$ \\
\hline 844 & NV & LOCKES & GRABLE & 530525 & 0.21 & 1.00 & 4.00 & 0.40 & 1 & $\mathrm{R}$ \\
\hline 844 & NV & LOCKES & HOW & 520605 & 1.23 & 1.25 & 4.00 & 0.40 & 2 & $\mathrm{R}$ \\
\hline 844 & NV & LOCKES & JOHNIE BOY & 620711 & 0.36 & 2.32 & 3.64 & 0.36 & 2 & $\mathrm{R}$ \\
\hline 844 & NV & LOCKES & NANCY & 530324 & 0.81 & 1.40 & 5.03 & 0.50 & 4 & I \\
\hline 844 & NV & LOCKES & OWENS & 570725 & 0.89 & 1.07 & 5.13 & 0.51 & 2 & $\mathrm{R}$ \\
\hline 844 & NV & LOCKES & SCHOONER & 681208 & 0.31 & 1.33 & 8.00 & 1.20 & 44 & $\mathrm{R}$ \\
\hline 844 & NV & LOCKES & SEDAN & 620706 & 1.81 & 1.74 & 5.83 & 0.58 & 11 & $\mathrm{R}$ \\
\hline 844 & NV & LOCKES & SHASTA & 570818 & 3.87 & 1.18 & 8.07 & 0.81 & 7 & $\mathrm{R}$ \\
\hline 844 & $\mathrm{NV}$ & LOCKES & SUGAR & 511119 & 1.22 & 1.40 & 3.00 & 0.30 & 4 & I \\
\hline 844 & NV & LOCKES & TURK & 550307 & 4.87 & 1.59 & 12.00 & 1.20 & 7 & $\mathrm{R}$ \\
\hline 844 & NV & LOCKES & UNCLE & 511129 & 0.44 & 1.40 & 5.00 & 0.50 & 3 & I \\
\hline
\end{tabular}




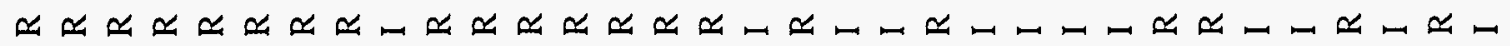

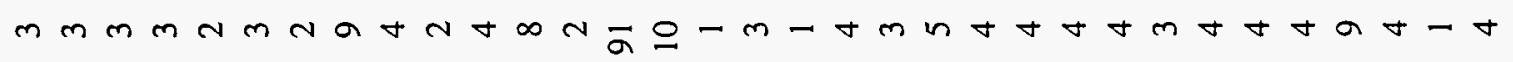

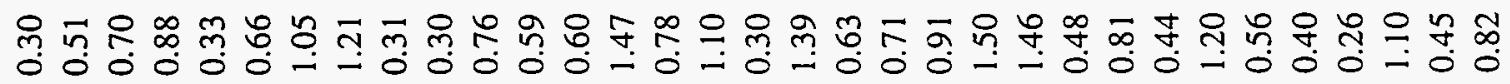

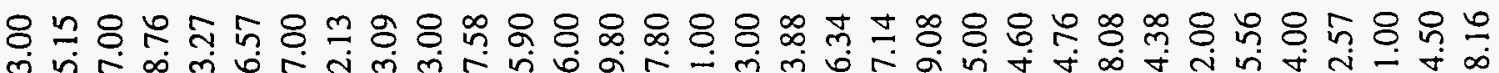
लं山

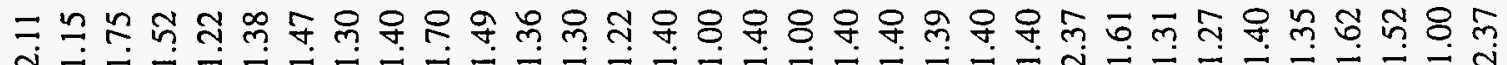

त̂

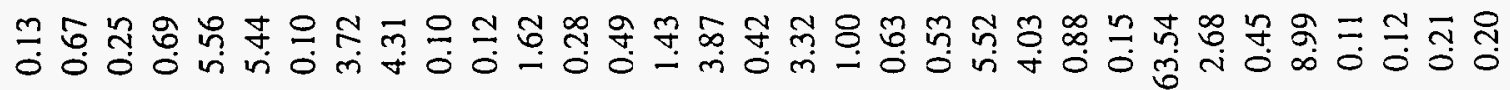

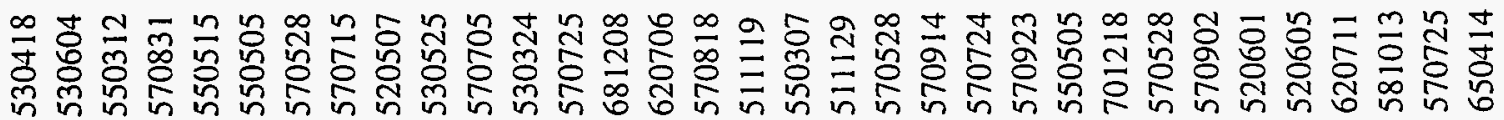

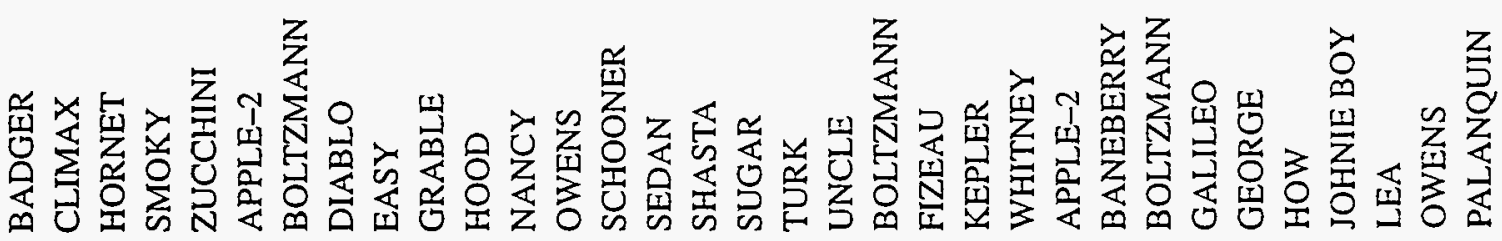

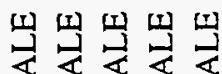

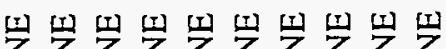

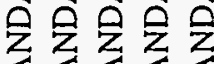

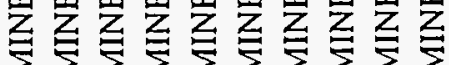

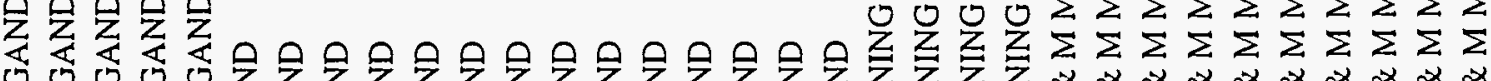

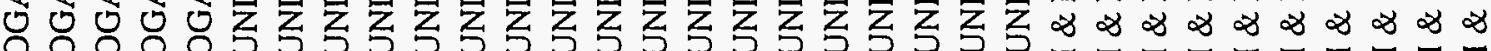

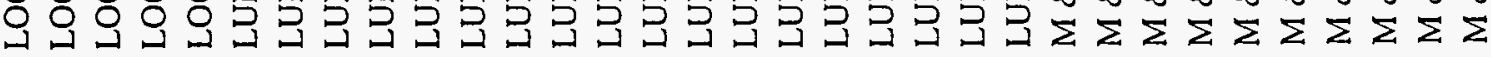

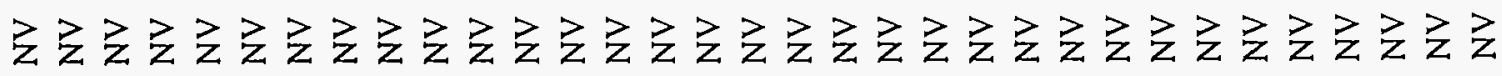

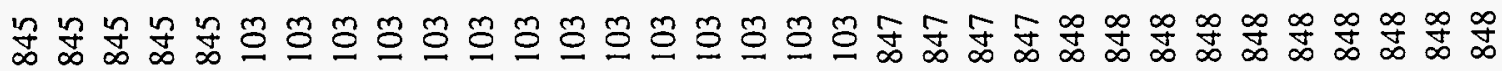




\begin{tabular}{|c|c|c|c|c|c|c|c|c|c|c|}
\hline Cntrl & State & Locale & Event & YYMMDD & $\mathrm{H} 12$ & $\mathrm{H} 12 \mathrm{D}$ & $\mathrm{TA}$ & TAD & NP & Orig \\
\hline 848 & NV & M \& M MINE & SCHOONER & 681208 & 0.06 & 1.66 & 4.02 & 0.40 & 4 & I \\
\hline 848 & NV & M \& M MINE & SUGAR & 511119 & 0.44 & 1.40 & 2.00 & 0.20 & 4 & I \\
\hline 848 & NV & M \& M MINE & TURK & 550307 & 0.44 & 1.24 & 10.77 & 1.08 & 3 & I \\
\hline 849 & NV & MANHATTAN & BOLTZMANN & 570528 & 1.89 & 1.29 & 5.35 & 0.53 & 9 & $\mathrm{R}$ \\
\hline 849 & NV & MANHATTAN & FIZEAU & 570914 & 0.57 & 1.25 & 8.42 & 0.84 & 2 & $\mathrm{R}$ \\
\hline 849 & NV & MANHATTAN & PALANQUIN & 650414 & 0.16 & 1.00 & 9.01 & 0.90 & 1 & - \\
\hline 849 & NV & MANHATTAN & SCHOONER & 681208 & 0.27 & 1.61 & 4.50 & 0.68 & 2 & $\mathrm{R}$ \\
\hline 849 & NV & MANHATTAN & WHITNEY & 570923 & 0.78 & 1.40 & 13.69 & 1.37 & 4 & I \\
\hline 112 & NV & MCGILL & APPLE-2 & 550505 & 2.68 & 2.05 & 8.10 & 0.81 & 4 & I \\
\hline 112 & NV & MCGILL & DIABLO & 570715 & 0.90 & 1.24 & 15.37 & 1.54 & 6 & $\mathrm{R}$ \\
\hline 112 & NV & MCGILL & DOPPLER & 570823 & 0.52 & 1.40 & 14.00 & 1.40 & 4 & I \\
\hline 112 & NV & MCGILL & NANCY & 530324 & 0.44 & 1.40 & 7.28 & 0.73 & 4 & I \\
\hline 112 & NV & MCGILL & OWENS & 570725 & 0.25 & 1.52 & 8.62 & 0.86 & 2 & $\mathrm{R}$ \\
\hline 112 & NV & MCGILL & SCHOONER & 681208 & 0.15 & 1.00 & 9.00 & 1.35 & 1 & $\mathrm{R}$ \\
\hline 112 & NV & MCGILL & SHASTA & 570818 & 1.45 & 1.40 & 13.46 & 1.35 & 4 & I \\
\hline 112 & NV & MCGILL & SUGAR & 511119 & 0.40 & 1.40 & 4.00 & 0.40 & 3 & I \\
\hline 112 & NV & MCGILL & TURK & 550307 & 0.59 & 1.00 & 15.03 & 1.50 & 1 & $\mathrm{R}$ \\
\hline 112 & NV & MCGILL & UNCLE & 511129 & 0.42 & 1.40 & 7.84 & 0.78 & 4 & I \\
\hline 2008 & $\mathrm{NV}$ & MELLAN & APPLE-2 & 550505 & 1.61 & 1.40 & 4.01 & 0.40 & 4 & I \\
\hline 2008 & NV & MELLAN & BANEBERRY & 701218 & 1.24 & 1.40 & 6.63 & 0.66 & 4 & I \\
\hline 2008 & NV & MELLAN & BOLTZMANN & 570528 & 0.37 & 1.35 & 2.76 & 0.28 & 5 & $\mathrm{R}$ \\
\hline 2008 & NV & MELLAN & CABRIOLET & 680126 & 0.24 & 1.40 & 1.16 & 0.12 & 4 & I \\
\hline 2008 & NV & MELLAN & DANNY BOY & 620305 & 0.06 & 1.98 & 2.00 & 0.20 & 12 & $\mathrm{R}$ \\
\hline 2008 & NV & MELLAN & FIZEAU & 570914 & 11.43 & 1.91 & 4.27 & 0.43 & 14 & $\mathrm{R}$ \\
\hline 2008 & NV & MELLAN & GALILEO & 570902 & 2.95 & 1.67 & 6.43 & 0.64 & 7 & $\mathrm{R}$ \\
\hline 2008 & NV & MELLAN & HOW & 520605 & 2.61 & 1.40 & 3.00 & 0.30 & 4 & I \\
\hline 2008 & NV & MELLAN & JOHNIE BOY & 620711 & 0.15 & 2.85 & 1.33 & 0.13 & 2 & $\mathrm{R}$ \\
\hline 2008 & NV & MELLAN & PALANQUIN & 650414 & 0.71 & 1.40 & 4.25 & 0.43 & 4 & I \\
\hline 2008 & NV & MELLAN & SCHOONER & 681208 & 5.54 & 1.40 & 1.72 & 0.17 & 4 & I \\
\hline 2008 & NV & MELLAN & TURK & 550307 & 19.06 & 1.40 & 7.11 & 0.71 & 4 & I \\
\hline 2008 & NV & MELLAN & WHEELER & 570906 & 1.16 & 1.00 & 3.50 & 0.52 & 1 & $\mathrm{R}$ \\
\hline 2008 & NV & MELLAN & WHITNEY & 570923 & 7.68 & 1.40 & 8.55 & 0.85 & 4 & I \\
\hline 850 & NV & MERCURY & BANDICOOT & 621019 & 0.23 & 1.71 & 1.87 & 0.19 & 76 & $\mathrm{R}$ \\
\hline
\end{tabular}




\begin{tabular}{|c|c|c|c|c|c|c|c|c|c|c|}
\hline Cntrl & State & Locale & Event & YYMMDD & $\mathrm{H} 12$ & $\mathrm{H} 12 \mathrm{D}$ & $\mathrm{TA}$ & TAD & NP & Orig \\
\hline 850 & NV & MERCURY & POST & 550409 & 1.23 & 1.14 & 7.67 & 0.77 & 3 & $\mathrm{R}$ \\
\hline 850 & NV & MERCURY & SIMON & 530425 & 0.10 & 1.00 & 5.00 & 0.75 & 1 & $\mathrm{R}$ \\
\hline 850 & NV & MERCURY & WHEELER & 570906 & 0.07 & 1.00 & 1.00 & 0.15 & 1 & $\mathrm{R}$ \\
\hline 850 & $\mathrm{NV}$ & MERCURY & WILSON & 570618 & 0.21 & 1.00 & 13.50 & 2.03 & 2 & $\mathrm{R}$ \\
\hline 851 & NV & MESQUITE & ANNIE & 530317 & 0.09 & 4.42 & 3.00 & 0.30 & 16 & $\mathrm{R}$ \\
\hline 851 & NV & MESQUITE & CLIMAX & 530604 & 0.40 & 1.00 & 5.50 & 0.55 & 1 & $\mathrm{R}$ \\
\hline 851 & NV & MESQUITE & ESS & 550323 & 0.24 & 1.87 & 8.59 & 0.86 & 2 & $\mathrm{R}$ \\
\hline 851 & NV & MESQUITE & HARRY & 530519 & 6.68 & 1.41 & 2.57 & 0.26 & 15 & $\mathrm{R}$ \\
\hline 851 & NV & MESQUITE & HORNET & 550312 & 0.24 & 1.77 & 8.26 & 0.83 & 6 & R \\
\hline 851 & NV & MESQUITE & SIMON & 530425 & 31.00 & 1.65 & 6.65 & 0.67 & 21 & $\mathrm{R}$ \\
\hline 851 & NV & MESQUITE & SMOKY & 570831 & 1.43 & 1.84 & 6.20 & 0.62 & 4 & $\mathrm{R}$ \\
\hline 851 & NV & MESQUITE & ZUCCHINI & 550515 & 1.61 & 1.99 & 3.34 & 0.33 & 11 & $\mathrm{R}$ \\
\hline 852 & NV & MILLETT & BOLTZMANN & 570528 & 10.71 & 1.15 & 6.57 & 0.66 & 4 & $\mathrm{R}$ \\
\hline 852 & $\mathrm{NV}$ & MILLETT & SCHOONER & 681208 & 0.08 & 1.31 & 5.00 & 0.75 & 2 & $\mathrm{R}$ \\
\hline 853 & NV & MINA & BOLTZMANN & 570528 & 1.20 & 2.55 & 7.00 & 0.70 & 2 & $\mathrm{R}$ \\
\hline 853 & NV & MINA & KEPLER & 570724 & 5.47 & 1.40 & 15.00 & 1.50 & 4 & I \\
\hline 853 & NV & MINA & WHEELER & 570906 & 0.19 & 1.00 & 12.00 & 1.80 & 1 & $\mathrm{R}$ \\
\hline 853 & $\mathrm{NV}$ & MINA & WHITNEY & 570923 & 0.59 & 1.00 & 13.92 & 1.39 & 1 & $\mathrm{R}$ \\
\hline 854 & NV & MOAPA & CLIMAX & 530604 & 0.67 & 1.00 & 4.57 & 0.46 & 1 & $\mathrm{R}$ \\
\hline 854 & NV & MOAPA & ESS & 550323 & 1.18 & 1.00 & 6.30 & 0.63 & 1 & $\mathrm{R}$ \\
\hline 854 & NV & MOAPA & HORNET & 550312 & 2.04 & 1.61 & 7.00 & 0.70 & 5 & $\mathrm{R}$ \\
\hline 854 & NV & MOAPA & PRISCILLA & 570624 & 0.17 & 1.00 & 9.00 & 1.35 & 1 & $\mathrm{R}$ \\
\hline 854 & NV & MOAPA & SMOKY & 570831 & 1.43 & 1.30 & 7.86 & 0.79 & 4 & $\mathrm{R}$ \\
\hline 854 & NV & MOAPA & ZUCCHINI & 550515 & 6.87 & 1.47 & 2.91 & 0.29 & 3 & $\mathrm{R}$ \\
\hline 855 & NV & MOAPA INDIAN RES. & ANNIE & 530317 & 0.13 & 1.00 & 3.00 & 0.30 & 1 & $\mathrm{R}$ \\
\hline 855 & NV & MOAPA INDIAN RES. & CLIMAX & 530604 & 1.13 & 1.90 & 4.39 & 0.44 & 4 & I \\
\hline 855 & NV & MOAPA INDIAN RES. & ESS & 550323 & 0.49 & 2.01 & 6.00 & 0.60 & 4 & I \\
\hline 855 & NV & MOAPA INDIAN RES. & HORNET & 550312 & 1.29 & 1.60 & 6.66 & 0.67 & 5 & $\mathrm{R}$ \\
\hline 855 & NV & MOAPA INDIAN RES. & SMOKY & 570831 & 1.15 & 1.00 & 7.78 & 0.78 & 1 & $\mathrm{R}$ \\
\hline 855 & NV & MOAPA INDIAN RES. & ZUCCHINI & 550515 & 13.60 & 1.00 & 2.81 & 0.28 & 1 & $\mathrm{R}$ \\
\hline 744 & NV & MONTGOMERY PASS & BOLTZMANN & 570528 & 3.49 & 1.00 & 7.00 & 1.05 & 1 & $\mathrm{R}$ \\
\hline 744 & NV & MONTGOMERY PASS & KEPLER & 570724 & 1.79 & 1.40 & 13.77 & 1.38 & 4 & I \\
\hline 744 & NV & MONTGOMERY PASS & WHITNEY & 570923 & 0.31 & 1.00 & 12.28 & 1.23 & 2 & 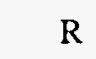 \\
\hline
\end{tabular}




\begin{tabular}{|c|c|c|c|c|c|c|c|c|c|c|}
\hline Cntrl & State & Locale & Event & YYMMDD & $\mathrm{H} 12$ & $\mathrm{H} 12 \mathrm{D}$ & $\mathrm{TA}$ & TAD & $\mathrm{NP}$ & Orig \\
\hline 856 & NV & MOON RIVER RANCH & APPLE-2 & 550505 & 0.50 & 1.40 & 5.22 & 0.52 & 3 & I \\
\hline 856 & NV & MOON RIVER RANCH & DIABLO & 570715 & 5.75 & 1.40 & 9.61 & 0.96 & 4 & I \\
\hline 856 & NV & MOON RIVER RANCH & EASY & 520507 & 9.97 & 1.40 & 2.12 & 0.21 & 4 & I \\
\hline 856 & NV & MOON RIVER RANCH & GRABLE & 530525 & 0.98 & 1.40 & 2.00 & 0.20 & 4 & I \\
\hline 856 & NV & MOON RIVER RANCH & HOOD & 570705 & 0.50 & 1.40 & 6.00 & 0.60 & 4 & I \\
\hline 856 & NV & MOON RIVER RANCH & NANCY & 530324 & 5.45 & 1.40 & 4.45 & 0.45 & 4 & I \\
\hline 856 & NV & MOON RIVER RANCH & OWENS & 570725 & 0.16 & 1.00 & 4.50 & 0.45 & 1 & $\mathrm{R}$ \\
\hline 856 & NV & MOON RIVER RANCH & RIO ARRIBA & 581018 & 0.08 & 1.40 & 3.00 & 0.30 & 4 & I \\
\hline 856 & NV & MOON RIVER RANCH & SCHOONER & 681208 & 1.02 & 1.34 & 6.50 & 0.98 & 19 & $\mathrm{R}$ \\
\hline 856 & NV & MOON RIVER RANCH & SEDAN & 620706 & 1.13 & 1.22 & 5.61 & 0.56 & 21 & $\mathrm{R}$ \\
\hline 856 & NV & MOON RIVER RANCH & TURK & 550307 & 2.47 & 1.40 & 12.63 & 1.26 & 4 & I \\
\hline 856 & NV & MOON RIVER RANCH & UNCLE & 511129 & 1.40 & 1.40 & 5.00 & 0.50 & 4 & I \\
\hline 2004 & NV & MOUNTAIN SPRINGS & BANDICOOT & 621019 & 0.17 & 1.36 & 5.00 & 0.50 & 2 & $\mathrm{R}$ \\
\hline 2004 & NV & MOUNTAIN SPRINGS & POST & 550409 & 0.40 & 1.40 & 18.00 & 1.80 & 3 & I \\
\hline 857 & NV & MOUNTS RANCH & APPLE-2 & 550505 & 1.15 & 1.40 & 8.15 & 0.82 & 4 & I \\
\hline 857 & NV & MOUNTS RANCH & DIABLO & 570715 & 2.64 & 1.16 & 14.35 & 1.43 & 4 & $\mathrm{R}$ \\
\hline 857 & NV & MOUNTS RANCH & DOPPLER & 570823 & 0.32 & 1.40 & 11.70 & 1.17 & 4 & I \\
\hline 857 & NV & MOUNTS RANCH & GRABLE & 530525 & 0.40 & 1.40 & 3.00 & 0.30 & 3 & I \\
\hline 857 & NV & MOUNTS RANCH & HOOD & 570705 & 0.24 & 1.40 & 8.77 & 0.88 & 4 & I \\
\hline 857 & NV & MOUNTS RANCH & NANCY & 530324 & 2.71 & 1.40 & 6.40 & 0.64 & 4 & I \\
\hline 857 & NV & MOUNTS RANCH & TURK & 550307 & 0.57 & 1.40 & 15.05 & 1.50 & 4 & I \\
\hline 857 & NV & MOUNTS RANCH & UNCLE & 511129 & 0.40 & 1.40 & 7.00 & 0.70 & 4 & I \\
\hline 858 & NV & NELLIS AIR FORCE BAS & BADGER & 530418 & 0.34 & 1.70 & 2.82 & 0.28 & 19 & $\mathrm{R}$ \\
\hline 858 & NV & NELLIS AIR FORCE BAS & HORNET & 550312 & 0.20 & 1.00 & 5.50 & 0.82 & 1 & $\mathrm{R}$ \\
\hline 858 & NV & NELLIS AIR FORCE BAS & ZUCCHINI & 550515 & 0.09 & 1.00 & 4.00 & 0.40 & 1 & $\mathrm{R}$ \\
\hline 860 & NV & NIVLOC MINE & KEPLER & 570724 & 3.46 & 1.40 & 9.27 & 0.93 & 4 & I \\
\hline 860 & NV & NIVLOC MINE & WHITNEY & 570923 & 2.23 & 1.20 & 10.04 & 1.00 & 4 & I \\
\hline 13 & NV & NORTH LAS VEGAS & BADGER & 530418 & 0.25 & 1.64 & 2.83 & 0.28 & 4 & $\mathrm{R}$ \\
\hline 13 & NV & NORTH LAS VEGAS & $\mathrm{BEE}$ & 550322 & 0.77 & 2.79 & 2.93 & 0.29 & 4 & I \\
\hline 13 & NV & NORTH LAS VEGAS & CLIMAX & 530604 & 0.13 & 1.00 & 7.00 & 0.70 & 1 & $\mathrm{R}$ \\
\hline 861 & NV & NYALA RANCH & APPLE-2 & 550505 & 8.06 & 1.00 & 3.65 & 0.37 & 1 & $\mathrm{R}$ \\
\hline 861 & NV & NYALA RANCH & DES MOINES & 620613 & 2.79 & 1.81 & 2.75 & 0.28 & 21 & $\mathrm{R}$ \\
\hline 861 & NV & NYALA RANCH & DIABLO & 570715 & 0.93 & 1.40 & 8.04 & 0.80 & 3 & I \\
\hline
\end{tabular}




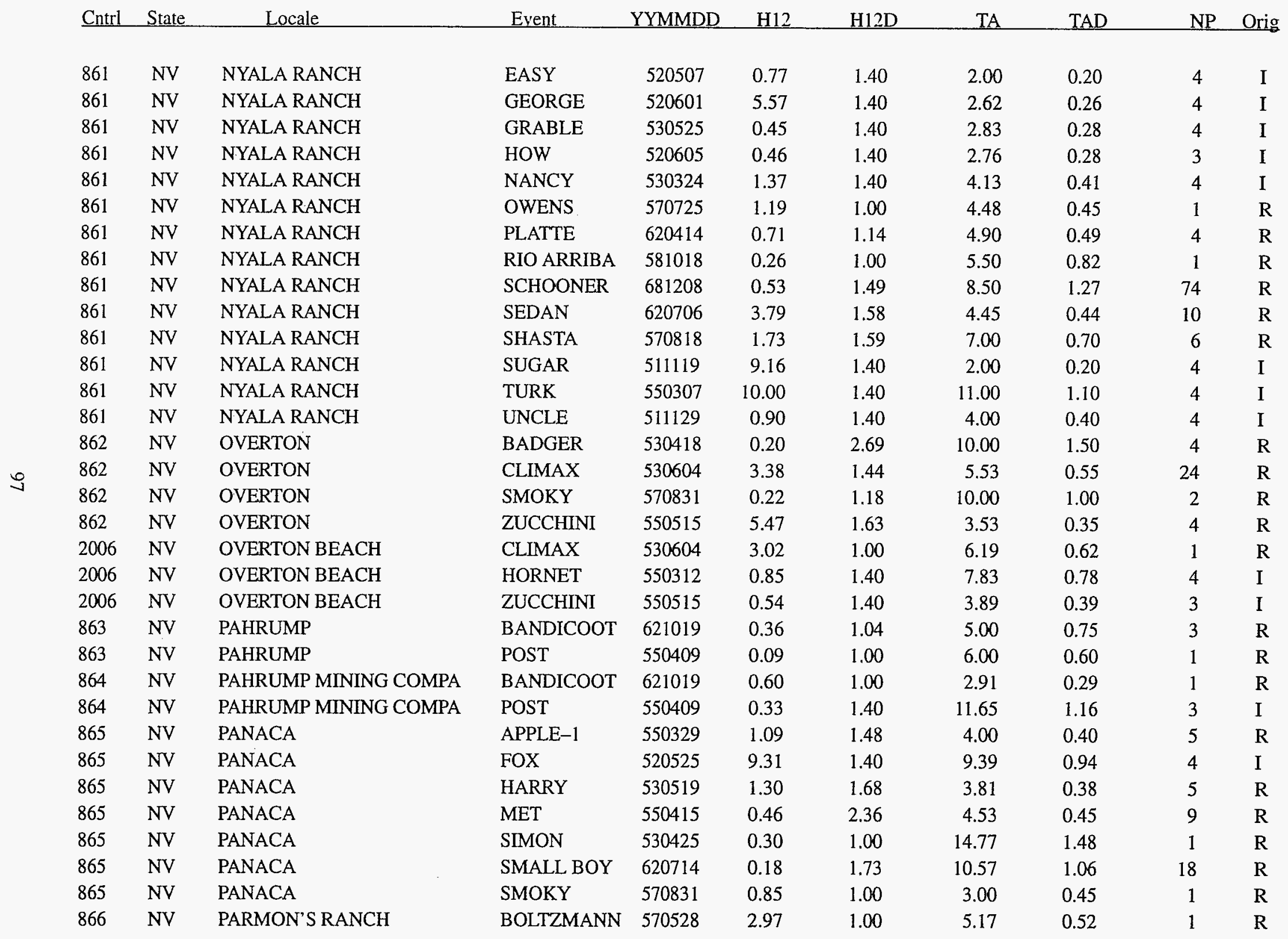




\begin{tabular}{lll} 
Cntrl & State & \multicolumn{1}{c}{ Locale } \\
\hline & & \\
866 & NV & PARMON'S RANCH \\
866 & NV & PARMON'S RANCH \\
866 & NV & PARMON'S RANCH \\
866 & NV & PARMON'S RANCH \\
866 & NV & PARMON'S RANCH \\
867 & NV & PIOCHE \\
867 & NV & PIOCHE \\
867 & NV & PIOCHE \\
867 & NV & PIOCHE \\
867 & NV & PIOCHE \\
867 & NV & PIOCHE \\
867 & NV & PIOCHE \\
867 & NV & PIOCHE \\
867 & NV & PIOCHE \\
868 & NV & PITTMAN \\
868 & NV & PITTMAN \\
869 & NV & PONY SPRINGS \\
869 & NV & PONY SPRINGS \\
869 & NV & PONY SPRINGS \\
869 & NV & PONY SPRINGS \\
869 & NV & PONY SPRINGS \\
869 & NV & PONY SPRINGS \\
869 & NV & PONY SPRINGS \\
869 & NV & PONY SPRINGS \\
869 & NV & PONY SPRINGS \\
869 & NV & PONY SPRINGS \\
871 & NV & POTTS \\
871 & NV & POTTS \\
871 & NV & POTTS \\
872 & NV & PRESTON \\
872 & NV & PRESTON \\
872 & NV & PRESTON \\
872 & NV & PRESTON \\
& & \\
8 &
\end{tabular}

YYMMDD $\mathrm{H} 12 \quad \mathrm{H} 12 \mathrm{D}$

TA TAD NP Orig

$\begin{array}{lrrrrrrl}\text { FIZEAU } & 570914 & 0.17 & 1.82 & 9.00 & 0.90 & 3 & \mathrm{R} \\ \text { HOW } & 520605 & 0.41 & 1.40 & 6.00 & 0.60 & 4 & \mathrm{I} \\ \text { PALANQUIN } & 650414 & 0.18 & 1.84 & 9.00 & 0.90 & 6 & \mathrm{R} \\ \text { SCHOONER } & 681208 & 0.14 & 1.00 & 4.50 & 0.68 & 1 & \mathrm{R} \\ \text { WHITNEY } & 570923 & 0.89 & 1.00 & 13.50 & 1.35 & 1 & \mathrm{R} \\ \text { APPLE-1 } & 550329 & 0.39 & 1.19 & 4.00 & 0.40 & 3 & \mathrm{R} \\ \text { DIABLO } & 570715 & 0.37 & 1.00 & 10.00 & 1.00 & \mathrm{I} & \mathrm{R} \\ \text { EASY } & 520507 & 1.60 & 1.39 & 1.50 & 0.15 & 12 & \mathrm{R} \\ \text { FOX } & 520525 & 12.46 & 1.31 & 9.78 & 0.98 & 11 & \mathrm{R} \\ \text { NEWTON* } & 570916 & 0.10 & 1.24 & 3.58 & 0.36 & 4 & \mathrm{I} \\ \text { SIMON } & 530425 & 0.30 & 1.00 & 16.00 & 1.60 & 1 & \mathrm{R} \\ \text { SMALL BOY } & 620714 & 0.17 & 1.31 & 10.48 & 1.05 & 9 & \mathrm{R} \\ \text { TURK } & 550307 & 0.15 & 1.92 & 13.50 & 1.35 & 3 & \mathrm{R} \\ \text { WILSON } & 570618 & 0.08 & 2.19 & 12.40 & 1.86 & 17 & \mathrm{R} \\ \text { BADGER } & 530418 & 1.81 & 1.00 & 3.00 & 0.30 & 1 & \mathrm{R} \\ \text { BEE } & 550322 & 0.19 & 1.00 & 3.35 & 0.33 & 2 & \mathrm{R} \\ \text { DIABLO } & 570715 & 7.32 & 1.32 & 10.79 & 1.08 & 2 & \mathrm{R} \\ \text { EASY } & 520507 & 2.08 & 1.66 & 2.00 & 0.20 & 5 & \mathrm{R} \\ \text { FOX } & 520525 & 0.72 & 1.40 & 10.90 & 1.09 & 4 & \mathrm{I} \\ \text { GRABLE } & 530525 & 0.06 & 1.96 & 2.00 & 0.20 & 2 & \mathrm{R} \\ \text { HOOD } & 570705 & 0.09 & 1.00 & 7.00 & 0.70 & 1 & \mathrm{R} \\ \text { NEWTON* } & 570916 & 0.10 & 1.46 & 4.01 & 0.40 & 4 & \mathrm{I} \\ \text { SCHOONER } & 681208 & 1.46 & 1.25 & 6.60 & 0.66 & 4 & \mathrm{R} \\ \text { SMALL BOY } & 620714 & 0.12 & 1.13 & 10.25 & 1.02 & 3 & \mathrm{R} \\ \text { TURK } & 550307 & 0.68 & 1.40 & 13.68 & 1.37 & 4 & \mathrm{I} \\ \text { WILSON } & 570618 & 0.50 & 1.40 & 10.23 & 1.02 & 3 & \mathrm{I} \\ \text { BOLTZMANN } & 570528 & 2.57 & 1.40 & 6.41 & 0.64 & 4 & \mathrm{I} \\ \text { HOW } & 520605 & 1.03 & 1.40 & 7.00 & 0.70 & 4 & \mathrm{I} \\ \text { SHASTA } & 570818 & 0.95 & 1.40 & 6.74 & 0.67 & 4 & \mathrm{I} \\ \text { APPLE-2 } & 550505 & 5.81 & 1.00 & 6.54 & 0.65 & 1 & \mathrm{R} \\ \text { BOLTZMANN } & 570528 & 0.11 & 1.33 & 7.00 & 1.05 & 2 & \mathrm{R} \\ \text { DIABLO } & 570715 & 2.99 & 1.38 & 12.24 & 1.22 & 5 & \mathrm{R} \\ \text { DOPPLER } & 570823 & 1.00 & 1.40 & 11.03 & 1.10 & 4 & \mathrm{I}\end{array}$




\begin{tabular}{|c|c|c|c|c|c|c|c|c|c|c|}
\hline Cntrl & State & Locale & Event & YYMMDD & $\mathrm{H} 12$ & $\mathrm{H} 12 \mathrm{D}$ & $\mathrm{TA}$ & TAD & $\mathrm{NP}$ & Orig \\
\hline 872 & NV & PRESTON & EASY & 520507 & 4.01 & 1.02 & 3.24 & 0.32 & 4 & I \\
\hline 872 & NV & PRESTON & GRABLE & 530525 & 0.10 & 1.75 & 3.00 & 0.30 & 2 & $\mathrm{R}$ \\
\hline 872 & NV & PRESTON & HOOD & 570705 & 0.14 & 1.00 & 8.00 & 0.80 & 1 & $\mathrm{R}$ \\
\hline 872 & NV & PRESTON & NANCY & 530324 & 1.21 & 1.19 & 6.05 & 0.60 & 6 & $\mathbf{R}$ \\
\hline 872 & NV & PRESTON & OWENS & 570725 & 0.86 & 1.92 & 6.03 & 0.60 & 2 & $\mathrm{R}$ \\
\hline 872 & NV & PRESTON & SEDAN & 620706 & 1.26 & 1.00 & 7.95 & 0.79 & 1 & $\mathrm{R}$ \\
\hline 872 & NV & PRESTON & SHASTA & 570818 & 3.96 & 1.00 & 11.03 & 1.10 & 1 & $\mathrm{R}$ \\
\hline 872 & NV & PRESTON & SUGAR & 511119 & 0.48 & 1.40 & 3.03 & 0.30 & 4 & I \\
\hline 872 & NV & PRESTON & TURK & 550307 & 2.39 & 1.14 & 14.00 & 1.40 & 2 & $\mathrm{R}$ \\
\hline 872 & NV & PRESTON & UNCLE & 511129 & 1.00 & 1.40 & 6.53 & 0.65 & 4 & I \\
\hline 873 & NV & RATTLESNAKE MAINTENA & APPLE-2 & 550505 & 6.69 & 1.20 & 4.58 & 0.46 & 6 & $\mathrm{R}$ \\
\hline 873 & NV & RATTLESNAKE MAINTENA & BANEBERRY & 701218 & 0.24 & 1.00 & 12.42 & 1.24 & 1 & $\mathrm{R}$ \\
\hline 873 & NV & RATTLESNAKE MAINTENA & GALILEO & 570902 & 1.00 & 1.40 & 12.00 & 1.20 & 3 & I \\
\hline 873 & NV & RATTLESNAKE MAINTENA & GEORGE & 520601 & 1.86 & 1.00 & 4.57 & 0.46 & 1 & $\mathrm{R}$ \\
\hline 873 & NV & RATTLESNAKE MAINTENA. & HOW & 520605 & 1.62 & 1.08 & 4.08 & 0.41 & 2 & $\mathrm{R}$ \\
\hline 873 & NV & RATTLESNAKE MAINTENA & JOHNIE BOY & 620711 & 1.09 & 1.27 & 3.39 & 0.34 & 2 & $\mathrm{R}$ \\
\hline 873 & NV & RATTLESNAKE MAINTENA & LEA & 581013 & 0.17 & 1.00 & 12.06 & 1.21 & 2 & $\mathbf{R}$ \\
\hline 873 & NV & RATTLESNAKE MAINTENA & NANCY & 530324 & 0.16 & 1.00 & 5.00 & 0.50 & 1 & $\mathrm{R}$ \\
\hline 873 & NV & RATTLESNAKE MAINTENA & OWENS & 570725 & 0.25 & 1.00 & 5.00 & 0.50 & 1 & $\mathrm{R}$ \\
\hline 873 & NV & RATTLESNAKE MAINTENA & SEDAN & 620706 & 0.10 & 1.74 & 5.50 & 0.55 & 4 & $\mathrm{R}$ \\
\hline 873 & NV & RATTLESNAKE MAINTENA & SHASTA & 570818 & 11.59 & 1.27 & 6.34 & 0.63 & 12 & $\mathrm{R}$ \\
\hline 873 & NV & RATTLESNAKE MAINTENA & SUGAR & 511119 & 0.72 & 1.40 & 2.33 & 0.23 & 4 & I \\
\hline 873 & NV & RATTLESNAKE MAINTENA & TURK & 550307 & 1.03 & 1.00 & 11.50 & 1.15 & 1 & $\mathrm{R}$ \\
\hline 874 & NV & REED & ANTLER & 610915 & 0.19 & 3.13 & 1.25 & 0.19 & 12 & $\mathrm{R}$ \\
\hline 874 & NV & REED & APPLE-2 & 550505 & 56.17 & 1.00 & 2.27 & 0.23 & 1 & $\mathrm{R}$ \\
\hline 874 & NV & REED & BANEBERRY & 701218 & 0.38 & 1.53 & 6.01 & 0.60 & 7 & $\mathrm{R}$ \\
\hline 874 & NV & REED & BOLTZMANN & 570528 & 1.22 & 1.33 & 2.59 & 0.26 & 4 & I \\
\hline 874 & NV & REED & DIABLO & 570715 & 3.83 & 1.40 & 5.16 & 0.52 & 4 & I \\
\hline 874 & NV & REED & EASY & 520507 & 0.12 & 1.04 & 2.00 & 0.30 & 2 & $\mathrm{R}$ \\
\hline 874 & NV & REED & FIZEAU & 570914 & 1.45 & 1.40 & 8.00 & 0.80 & 2 & $\mathrm{R}$ \\
\hline 874 & NV & REED & FOX & 520525 & 3.24 & 1.00 & 8.00 & 0.80 & 1 & $\mathrm{R}$ \\
\hline 874 & NV & REED & GALILEO & 570902 & 7.25 & 1.50 & 11.56 & 1.16 & 14 & $\mathrm{R}$ \\
\hline 874 & NV & REED & GEORGE & 520601 & 0.72 & 1.00 & 2.80 & 0.28 & 1 & $\mathrm{R}$ \\
\hline
\end{tabular}




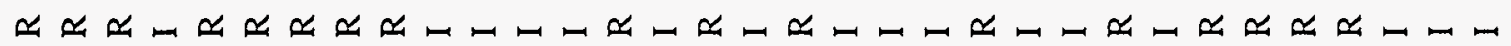

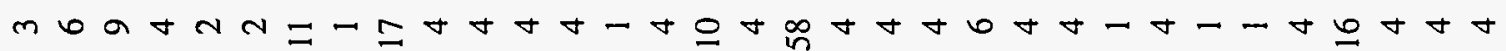

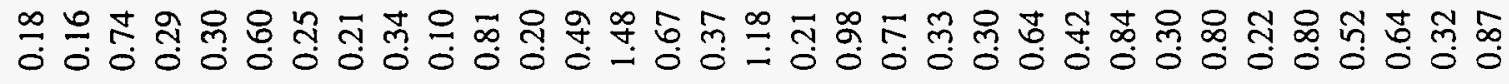

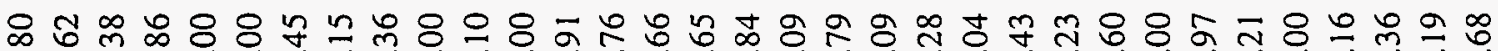

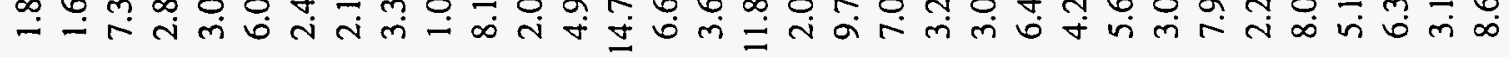

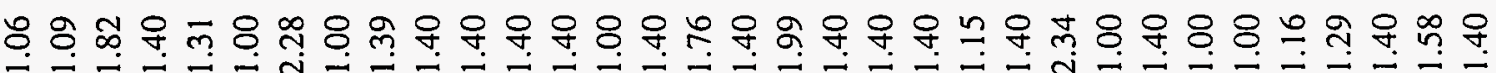

음후웜 궁

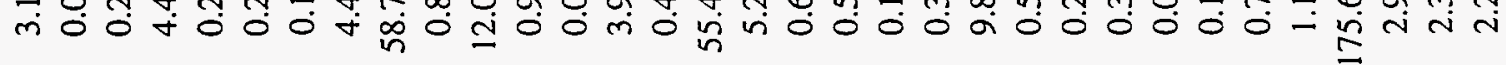

茖

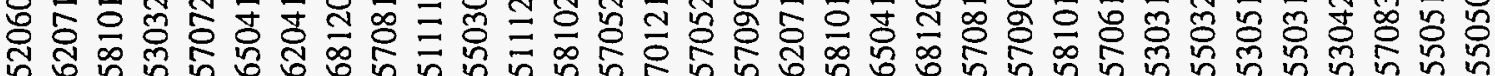

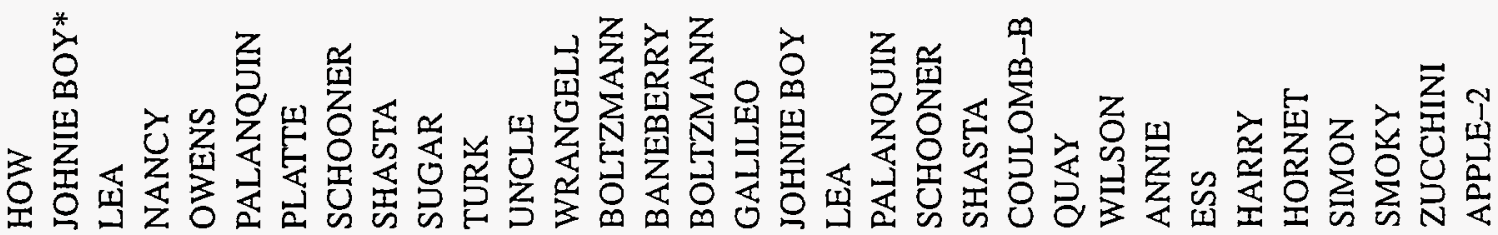

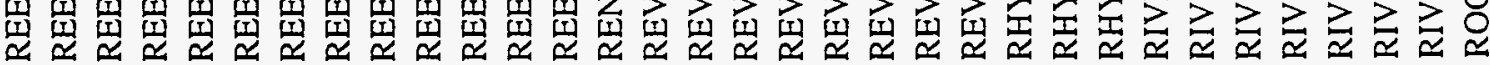

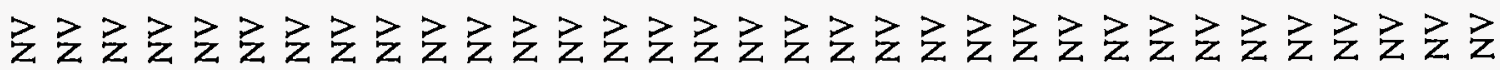

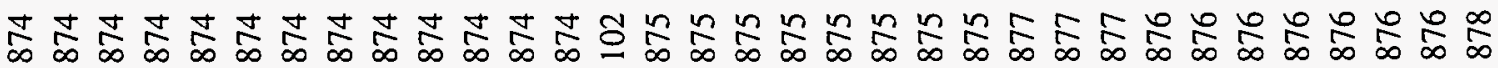




\begin{tabular}{|c|c|c|c|c|c|c|c|c|c|c|}
\hline Cntrl & State & Locale & Event & YYMMDD & $\mathrm{H} 12$ & $\mathrm{H} 12 \mathrm{D}$ & $\mathrm{TA}$ & TAD & NP & Orig \\
\hline 878 & NV & ROGERS RANCH & DIABLO & 570715 & 1.82 & 1.40 & 15.58 & 1.56 & 4 & $\mathrm{I}$ \\
\hline 878 & NV & ROGERS RANCH & DOPPLER & 570823 & 0.99 & 1.40 & 13.69 & 1.37 & 4 & I \\
\hline 878 & NV & ROGERS RANCH & HOOD & 570705 & 0.10 & 1.40 & 9.00 & 0.90 & 3 & I \\
\hline 878 & NV & ROGERS RANCH & NANCY & 530324 & 0.67 & 1.40 & 6.91 & 0.69 & 4 & I \\
\hline 878 & NV & ROGERS RANCH & OWENS & 570725 & 0.14 & 1.40 & 8.00 & 0.80 & 4 & $\mathrm{I}$ \\
\hline 878 & NV & ROGERS RANCH & UNCLE & 511129 & 0.40 & 1.40 & 8.00 & 0.80 & 4 & I \\
\hline 879 & NV & ROSE VALLEY & APPLE-1 & 550329 & 0.34 & 1.40 & 4.35 & 0.43 & 4 & I \\
\hline 879 & NV & ROSE VALLEY & FOX & 520525 & 10.79 & 1.40 & 10.29 & 1.03 & 4 & I \\
\hline 879 & NV & ROSE VALLEY & MET & 550415 & 0.36 & 1.40 & 5.00 & 0.50 & 4 & I \\
\hline 879 & NV & ROSE VALLEY & SMALL BOY & 620714 & 0.12 & 1.40 & 11.72 & 1.76 & 4 & I \\
\hline 880 & NV & ROUND MOUNTAIN & BOLTZMANN & 570528 & 4.83 & 1.00 & 5.76 & 0.58 & 1 & $\mathrm{R}$ \\
\hline 880 & NV & ROUND MOUNTAIN & SCHOONER & 681208 & 0.13 & 1.00 & 8.50 & 1.27 & 1 & $\mathrm{R}$ \\
\hline 880 & NV & ROUND MOUNTAIN & WHEELER & 570906 & 0.12 & 1.00 & 10.00 & 1.50 & 1 & R \\
\hline 880 & NV & ROUND MOUNTAIN & WHITNEY & 570923 & 0.65 & 1.40 & 14.62 & 1.46 & 3 & I \\
\hline 881 & NV & ROX & ANNIE & 530317 & 5.61 & 1.40 & 2.59 & 0.26 & 4 & $I$ \\
\hline 881 & NV & ROX & ESS & 550323 & 1.02 & 1.40 & 6.25 & 0.62 & 4 & I \\
\hline 881 & NV & ROX & HARRY & 530519 & 11.19 & 1.40 & 1.71 & 0.17 & 4 & I \\
\hline 881 & $\mathrm{NV}$ & ROX & HORNET & 550312 & 4.15 & 1.40 & 6.72 & 0.67 & 4 & I \\
\hline 881 & NV & ROX & SIMON & 530425 & 11.19 & 1.40 & 3.83 & 0.38 & 4 & I \\
\hline 881 & NV & ROX & SMALL BOY & 620714 & 0.08 & 1.00 & 5.00 & 0.50 & 1 & $\mathrm{R}$ \\
\hline 881 & NV & ROX & SMOKY & 570831 & 4.05 & 1.40 & 5.14 & 0.51 & 8 & $\mathrm{R}$ \\
\hline 881 & NV & ROX & TESLA & 550301 & 0.71 & 1.83 & 5.00 & 0.50 & 5 & $\mathrm{R}$ \\
\hline 881 & NV & ROX & TURK & 550307 & 0.42 & 1.40 & 9.97 & 1.00 & 3 & I \\
\hline 881 & NV & ROX & ZUCCHINI & 550515 & 2.90 & 1.40 & 2.23 & 0.22 & 4 & I \\
\hline 882 & NV & RUBY HILL MINE & APPLE-2 & 550505 & 0.57 & 1.00 & 7.09 & 0.71 & 1 & $\mathrm{R}$ \\
\hline 882 & NV & RUBY HILL MINE & BOLTZMANN & 570528 & 0.94 & 1.22 & 8.32 & 0.83 & 3 & $\mathrm{R}$ \\
\hline 882 & NV & RUBY HILL MINE & GEORGE & 520601 & 2.63 & 1.00 & 6.77 & 0.68 & 1 & $\mathrm{R}$ \\
\hline 882 & NV & RUBY HILL MINE & HOW & 520605 & 1.00 & 1.40 & 7.00 & 0.70 & 2 & I \\
\hline 882 & NV & RUBY HILL MINE & OWENS & 570725 & 0.48 & 1.59 & 8.00 & 0.80 & 6 & $\mathrm{R}$ \\
\hline 882 & NV & RUBY HILL MINE & SCHOONER & 681208 & 0.06 & 1.40 & 13.00 & 1.95 & 2 & $\mathrm{R}$ \\
\hline 882 & NV & RUBY HILL MINE & SHASTA & 570818 & 6.22 & 1.54 & 12.82 & 1.28 & 11 & $\mathrm{R}$ \\
\hline 882 & NV & RUBY HILL MINE & SUGAR & 511119 & 1.23 & 1.40 & 4.00 & 0.40 & 2 & I \\
\hline 883 & NV & RUTH & APPLE-2 & 550505 & 3.78 & 1.63 & 7.38 & 0.74 & 4 & I \\
\hline
\end{tabular}




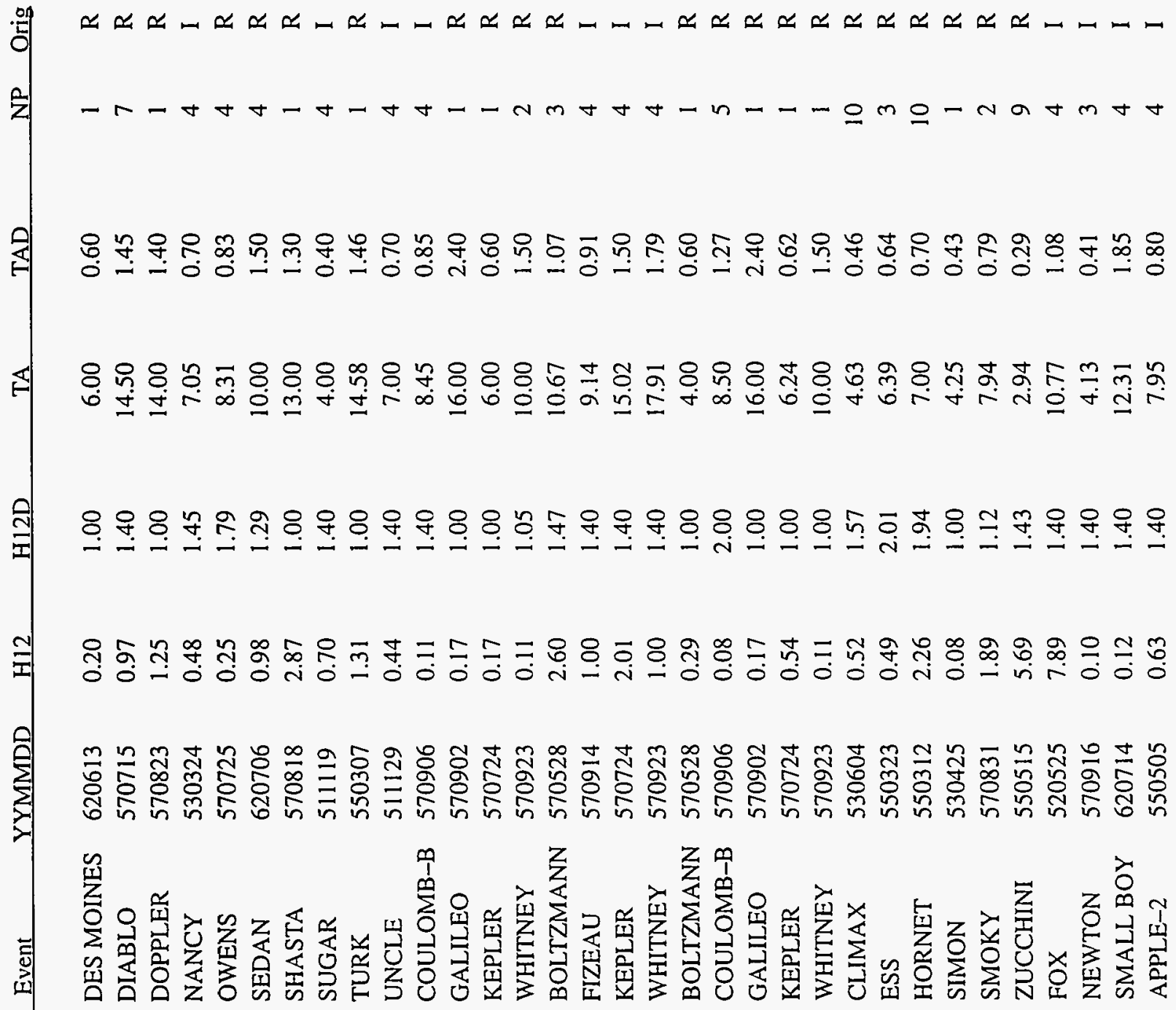

z z z z

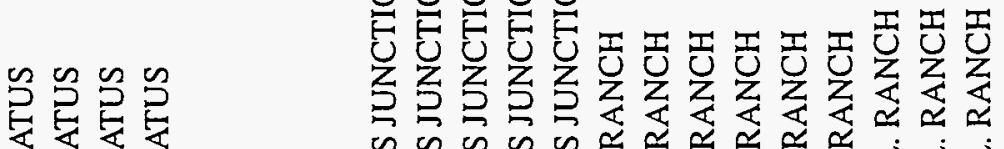
定究 各

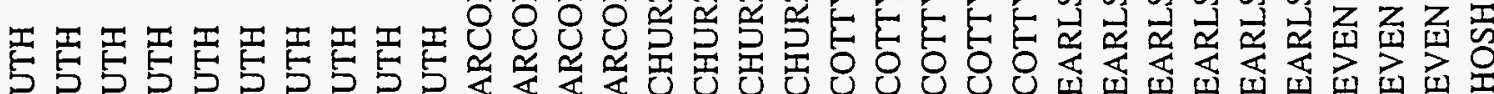

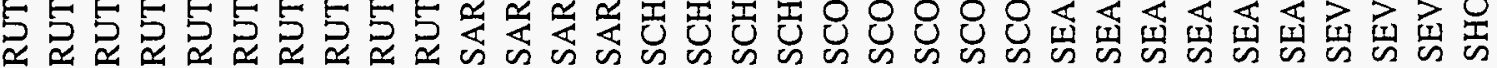

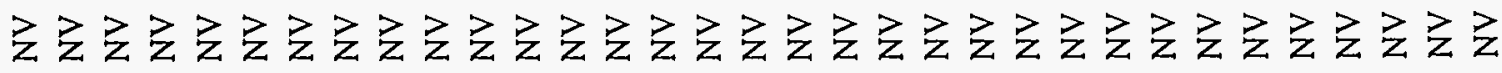
య 


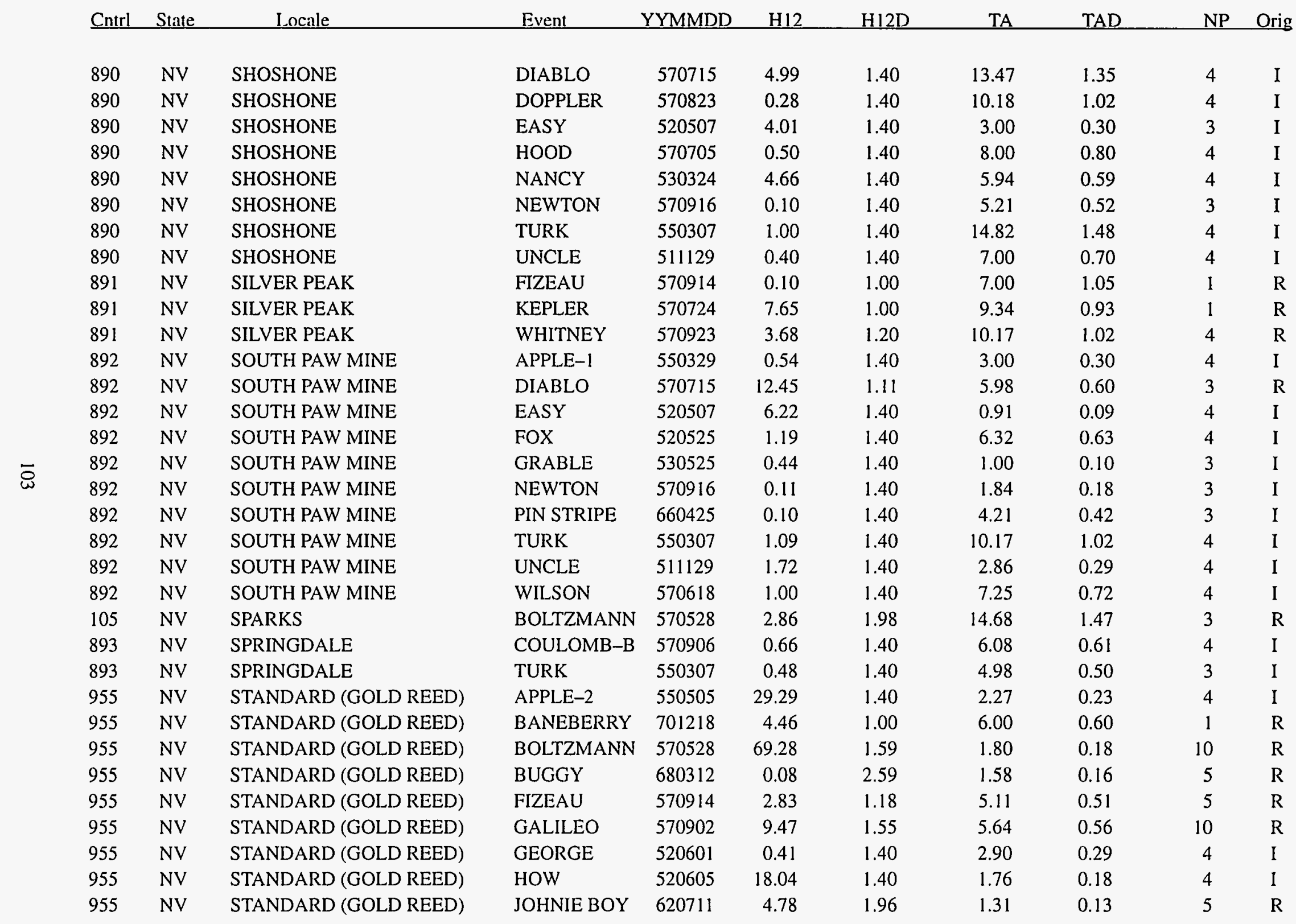




\begin{tabular}{|c|c|c|c|c|c|c|c|c|c|c|}
\hline Cntrl & State & Locale & Event & YYMMDD & $\mathrm{H} 12$ & $\mathrm{H} 12 \mathrm{D}$ & $\mathrm{TA}$ & TAD & NP & Orig \\
\hline 955 & NV & STANDARD (GOLD REED) & LEA & 581013 & 0.84 & 1.16 & 5.45 & 0.54 & 5 & $\mathrm{R}$ \\
\hline 955 & NV & STANDARD (GOLD REED) & NANCY & 530324 & 1.97 & 1.40 & 2.37 & 0.24 & 4 & I \\
\hline 955 & NV & STANDARD (GOLD REED) & PALANQUIN & 650414 & 0.06 & 1.40 & 3.93 & 0.39 & 3 & I \\
\hline 955 & NV & STANDARD (GOLD REED) & SCHOONER & 681208 & 0.15 & 1.40 & 1.18 & 0.12 & 4 & I \\
\hline 955 & NV & STANDARD (GOLD REED) & SHASTA & 570818 & 134.70 & 1.57 & 1.72 & 0.17 & 18 & $\mathrm{R}$ \\
\hline 955 & NV & STANDARD (GOLD REED) & SUGAR & 511119 & 0.41 & 1.40 & 1.00 & 0.10 & 4 & I \\
\hline 955 & NV & STANDARD (GOLD REED) & SULKY & 641218 & 0.28 & 2.24 & 2.20 & 0.33 & 138 & $\mathrm{R}$ \\
\hline 955 & NV & STANDARD (GOLD REED) & TURK & 550307 & 30.58 & 1.40 & 6.61 & 0.66 & 4 & I \\
\hline 955 & NV & STANDARD (GOLD REED) & UNCLE & 511129 & 0.46 & 1.40 & 1.53 & 0.15 & 4 & I \\
\hline 955 & NV & STANDARD (GOLD REED) & WHITNEY & 570923 & 0.16 & 1.00 & 6.07 & 0.61 & 1 & $\mathrm{R}$ \\
\hline 895 & NV & STEWARD R. RANCH & DIABLO & 570715 & 6.77 & 1.32 & 10.14 & 1.01 & 4 & I \\
\hline 895 & NV & STEWARD R. RANCH & DOPPLER & 570823 & 0.11 & 1.40 & 6.00 & 0.60 & 4 & I \\
\hline 895 & NV & STEWARD R. RANCH & EASY & 520507 & 2.56 & 1.40 & 2.00 & 0.20 & 4 & I \\
\hline 895 & NV & STEWARD R. RANCH & EDDY & 580919 & 0.11 & 1.40 & 6.58 & 0.66 & 4 & I \\
\hline 895 & NV & STEWARD R. RANCH & FOX & 520525 & 0.82 & 1.40 & 10.45 & 1.04 & 4 & I \\
\hline 895 & NV & STEWARD R. RANCH & GRABLE & 530525 & 0.40 & 1.96 & 2.00 & 0.20 & 3 & I \\
\hline 895 & NV & STEWARD R. RANCH & HOOD & 570705 & 0.28 & 1.40 & 6.49 & 0.65 & 4 & I \\
\hline 895 & NV & STEWARD R. RANCH & NEWTON & 570916 & 0.10 & 1.40 & 3.74 & 0.37 & 4 & I \\
\hline 895 & NV & STEWARD R. RANCH & SCHOONER & 681208 & 0.16 & 1.25 & 6.17 & 0.62 & 4 & I \\
\hline 895 & NV & STEWARD R. RANCH & SMALL BOY & 620714 & 0.10 & 1.13 & 10.08 & 1.01 & 4 & I \\
\hline 895 & NV & STEWARD R. RANCH & TURK & 550307 & 0.71 & 1.40 & 13.26 & 1.33 & 4 & 1 \\
\hline 895 & NV & STEWARD R. RANCH & WILSON & 570618 & 0.50 & 1.40 & 10.83 & 1.08 & 3 & I \\
\hline 896 & NV & STINE & APPLE-1 & 550329 & 2.34 & 1.83 & 3.69 & 0.37 & 4 & $\mathrm{R}$ \\
\hline 896 & NV & STINE & FOX & 520525 & 1.08 & 1.40 & 7.56 & 0.76 & 4 & I \\
\hline 896 & NV & STINE & HARRY & 530519 & 5.89 & 1.40 & 3.03 & 0.30 & 4 & I \\
\hline 896 & NV & STINE & HORNET & 550312 & 0.57 & 1.40 & 8.20 & 0.82 & 4 & I \\
\hline 896 & NV & STINE & MET & 550415 & 6.79 & 1.65 & 4.00 & 0.40 & 2 & $\mathrm{R}$ \\
\hline 896 & NV & STINE & PRISCILLA & 570624 & 0.15 & 1.85 & 8.00 & 0.80 & 3 & $\mathrm{R}$ \\
\hline 896 & NV & STINE & SIMON & 530425 & 0.73 & 1.40 & 12.40 & 1.24 & 4 & $\mathrm{I}$ \\
\hline 896 & NV & STINE & SMALL BOY & 620714 & 0.18 & 1.15 & 8.00 & 1.20 & 2 & $\mathrm{R}$ \\
\hline 896 & NV & STINE & SMOKY & 570831 & 0.09 & 1.00 & 9.00 & 1.35 & 1 & $\mathrm{R}$ \\
\hline 897 & NV & STONE CABIN RANCH & APPLE-2 & 550505 & 0.49 & 1.40 & 4.98 & 0.50 & 4 & I \\
\hline 897 & NV & STONE CABIN RANCH & BANEBERRY & 701218 & 0.32 & 1.26 & 7.81 & 0.78 & 43 & $\mathrm{R}$ \\
\hline
\end{tabular}




\begin{tabular}{|c|c|c|c|c|c|c|c|c|c|c|}
\hline$\underline{\text { Cntrl }}$ & State & Locale & Event & YYMMDD & $\mathrm{H} 12$ & H12D & $\mathrm{TA}$ & TAD & NP & Orig \\
\hline 897 & NV & STONE CABIN RANCH & BOLTZMANN & 570528 & 7.43 & 1.21 & 4.30 & 0.43 & 5 & $\mathrm{R}$ \\
\hline 897 & NV & STONE CABIN RANCH & CABRIOLET & 680126 & 0.48 & 1.94 & 2.59 & 0.26 & 42 & $\mathrm{R}$ \\
\hline 897 & NV & STONE CABIN RANCH & DANNY BOY & 620305 & 0.07 & 2.41 & 2.82 & 0.28 & 2 & $\mathrm{R}$ \\
\hline 897 & NV & STONE CABIN RANCH & GALILEO & 570902 & 2.00 & 1.00 & 10.00 & 1.00 & 1 & $\mathrm{R}$ \\
\hline 897 & NV & STONE CABIN RANCH & HOW & 520605 & 8.17 & 1.34 & 4.19 & 0.42 & 4 & $I$ \\
\hline 897 & NV & STONE CABIN RANCH & PALANQUIN & 650414 & 0.34 & 2.35 & 7.26 & 0.73 & 246 & $\mathrm{R}$ \\
\hline 897 & NV & STONE CABIN RANCH & SCHOONER & 681208 & 0.57 & 1.49 & 4.05 & 0.40 & 57 & $\mathrm{R}$ \\
\hline 897 & NV & STONE CABIN RANCH & SHASTA & 570818 & 0.08 & 1.00 & 3.00 & 0.30 & 1 & $\mathrm{R}$ \\
\hline 897 & NV & STONE CABIN RANCH & SUGAR & 511119 & 0.40 & 1.40 & 2.00 & 0.20 & 4 & I \\
\hline 898 & NV & SUNNYSIDE & APPLE-2 & 550505 & 0.07 & 1.91 & 5.50 & 0.55 & 7 & $\mathrm{R}$ \\
\hline 898 & $\mathrm{NV}$ & SUNNYSIDE & DIABLO & 570715 & 8.40 & 1.08 & 10.14 & 1.01 & 3 & $\mathrm{R}$ \\
\hline 898 & NV & SUNNYSIDE & EASY & 520507 & 9.97 & 1.40 & 2.00 & 0.20 & 4 & I \\
\hline 898 & NV & SUNNYSIDE & EDDY & 580919 & 0.07 & 1.40 & 6.86 & 0.69 & 4 & 1 \\
\hline 898 & NV & SUNNYSIDE & GRABLE & 530525 & 0.75 & 1.40 & 2.00 & 0.20 & 4 & I \\
\hline 898 & NV & SUNNYSIDE & HOOD & 570705 & 0.27 & 1.07 & 6.26 & 0.63 & 4 & $\mathrm{R}$ \\
\hline 898 & NV & SUNNYSIDE & NANCY & 530324 & 11.78 & 1.00 & 4.67 & 0.47 & 1 & $\mathrm{R}$ \\
\hline 898 & NV & SUNNYSIDE & SCHOONER & 681208 & 0.75 & 1.21 & 5.78 & 0.58 & 18 & $\mathrm{R}$ \\
\hline 898 & NV & SUNNYSIDE & SEDAN & 620706 & 0.37 & 1.69 & 5.99 & 0.60 & 3 & $\mathrm{R}$ \\
\hline 898 & NV & SUNNYSIDE & TURK & 550307 & 1.59 & 1.40 & 13.00 & 1.30 & 4 & I \\
\hline 898 & NV & SUNNYSIDE & UNCLE & 511129 & 0.89 & 1.40 & 5.26 & 0.53 & 4 & I \\
\hline 899 & NV & SWALOW RANCH & APPLE-2 & 550505 & 0.81 & 1.40 & 8.02 & 0.80 & 4 & I \\
\hline 899 & NV & SWALOW RANCH & DIABLO & 570715 & 5.17 & 1.40 & 13.83 & 1.38 & 4 & $\mathrm{I}$ \\
\hline 899 & NV & SWALOW RANCH & DOPPLER & 570823 & 0.27 & 1.40 & 10.66 & 1.07 & 4 & I \\
\hline 899 & NV & SWALOW RANCH & HOOD & 570705 & 0.50 & 1.40 & 8.09 & 0.81 & 4 & I \\
\hline 899 & NV & SWALOW RANCH & NANCY & 530324 & 6.79 & 1.40 & 6.10 & 0.61 & 4 & I \\
\hline 899 & NV & SWALOW RANCH & TURK & 550307 & 0.97 & 1.40 & 14.91 & 1.49 & 4 & I \\
\hline 899 & NV & SWALOW RANCH & UNCLE & 511129 & 0.40 & 1.40 & 7.00 & 0.70 & 4 & I \\
\hline 2010 & NV & TEMPIUTE & APPLE-I & 550329 & 0.16 & 1.26 & 2.50 & 0.25 & 9 & $\mathrm{R}$ \\
\hline 2010 & NV & TEMPIUTE & APPLE-2 & 550505 & 0.17 & 2.85 & 2.30 & 0.34 & 2 & $\mathrm{R}$ \\
\hline 2010 & NV & TEMPIUTE & DIABLO & 570715 & 12.82 & 1.73 & 5.27 & 0.53 & 43 & $\mathrm{R}$ \\
\hline 2010 & NV & TEMPIUTE & EASY & 520507 & 11.85 & 1.45 & 0.86 & 0.09 & 100 & $\mathrm{R}$ \\
\hline 2010 & NV & TEMPIUTE & EDDY & 580919 & 0.14 & 2.97 & 5.00 & 0.50 & 12 & $\mathrm{R}$ \\
\hline 2010 & NV & TEMPIUTE & FOX & 520525 & 1.08 & 1.19 & 6.06 & 0.61 & 3 & $\mathrm{R}$ \\
\hline
\end{tabular}




\begin{tabular}{|c|c|c|c|c|c|c|c|c|c|c|}
\hline Cntrl & State & Locale & Event & YYMMDD & $\mathrm{H} 12$ & $\mathrm{H} 12 \mathrm{D}$ & $\mathrm{TA}$ & TAD & NP & Orig \\
\hline 2010 & NV & TEMPIUTE & GRABLE & 530525 & 0.43 & 1.49 & 1.00 & 0.10 & 39 & $\mathrm{R}$ \\
\hline 2010 & NV & TEMPIUTE & HOOD & 570705 & 0.49 & 1.56 & 2.24 & 0.22 & 18 & $\mathbf{R}$ \\
\hline 2010 & NV & TEMPIUTE & NANCY & 530324 & 35.86 & 1.38 & 1.89 & 0.19 & 116 & $\mathrm{R}$ \\
\hline 2010 & NV & TEMPIUTE & RIO ARRIBA & 581018 & 0.35 & 1.40 & 2.00 & 0.20 & 4 & I \\
\hline 2010 & NV & TEMPIUTE & SCHOONER & 681208 & 0.63 & 1.00 & 3.00 & 0.30 & 1 & $\mathrm{R}$ \\
\hline 2010 & NV & TEMPIUTE & SEDAN & 620706 & 0.25 & 3.30 & 3.00 & 0.45 & 9 & $\mathrm{R}$ \\
\hline 2010 & NV & TEMPIUTE & SHASTA & 570818 & 0.24 & 1.00 & 10.00 & 1.50 & 1 & $\mathrm{R}$ \\
\hline 2010 & NV & TEMPIUTE & SUGAR & 511119 & 0.46 & 1.40 & 1.00 & 0.10 & 3 & I \\
\hline 2010 & NV & TEMPIUTE & TURK & 550307 & 0.69 & 1.63 & 9.26 & 0.93 & 2 & $\mathrm{R}$ \\
\hline 2010 & NV & TEMPIUTE & UNCLE & 511129 & 12.20 & 1.40 & 2.06 & 0.21 & 4 & I \\
\hline 87 & NV & TONOPAH & BANEBERRY & 701218 & 0.07 & 1.71 & 14.69 & 1.47 & 8 & $\mathrm{R}$ \\
\hline 87 & NV & TONOPAH & BOLTZMANN & 570528 & 0.49 & 1.69 & 4.83 & 0.48 & 24 & $\mathrm{R}$ \\
\hline 87 & NV & TONOPAH & FIZEAU & 570914 & 3.92 & 1.78 & 5.64 & 0.56 & 68 & $\mathrm{R}$ \\
\hline 87 & NV & TONOPAH & GALILEO & 570902 & 0.15 & 1.56 & 15.00 & 2.25 & 3 & $\mathrm{R}$ \\
\hline 87 & NV & TONOPAH & KEPLER & 570724 & 0.28 & 1.18 & 12.42 & 1.24 & 3 & $\mathrm{R}$ \\
\hline 87 & NV & TONOPAH & WHITNEY & 570923 & 11.69 & 1.50 & 11.30 & 1.13 & 26 & $\mathrm{R}$ \\
\hline 900 & NV & TONOPAH AIRPORT & BOLTZMANN & 570528 & 0.38 & 1.00 & 4.54 & 0.45 & 1 & $\mathrm{R}$ \\
\hline 900 & NV & TONOPAH AIRPORT & FIZEAU & 570914 & 4.50 & 1.40 & 5.44 & 0.54 & 4 & I \\
\hline 900 & NV & TONOPAH AIRPORT & WHITNEY & 570923 & 4.62 & 1.00 & 11.19 & 1.12 & 1 & $\mathrm{R}$ \\
\hline 2009 & NV & TYBO & APPLE-2 & 550505 & 1.28 & 1.40 & 4.89 & 0.49 & 4 & I \\
\hline 2009 & NV & TYBO & BANEBERRY & 701218 & 0.16 & 1.40 & 10.51 & 1.05 & 4 & I \\
\hline 2009 & NV & TYBO & BOLTZMANN & 570528 & 3.38 & 1.40 & 4.86 & 0.49 & 4 & I \\
\hline 2009 & NV & TYBO & GALILEO & 570902 & 1.20 & 1.40 & 12.00 & 1.20 & 4 & I \\
\hline 2009 & NV & TYBO & GEORGE & 520601 & 0.69 & 1.40 & 5.61 & 0.56 & 4 & I \\
\hline 2009 & NV & TYBO & HOW & 520605 & 6.73 & 1.40 & 4.17 & 0.42 & 4 & I \\
\hline 2009 & NV & TYBO & JOHNIE BOY & 620711 & 0.07 & 1.40 & 3.20 & 0.32 & 4 & I \\
\hline 2009 & NV & TYBO & LEA & 581013 & 0.12 & 1.40 & 11.76 & 1.18 & 4 & I \\
\hline 2009 & NV & TYBO & PALANQUIN & 650414 & 0.15 & 1.40 & 9.00 & 0.90 & 4 & I \\
\hline 2009 & NV & TYBO & SUGAR & 511119 & 0.42 & 1.40 & 2.19 & 0.22 & 4 & I \\
\hline 901 & NV & UHALDE RANCH & APPLE-2 & 550505 & 5.09 & 1.40 & 3.59 & 0.36 & 4 & I \\
\hline 901 & NV & UHALDE RANCH & DIABLO & 570715 & 5.92 & 1.24 & 7.59 & 0.76 & 22 & $\mathrm{R}$ \\
\hline 901 & NV & UHALDE RANCH & EASY & 520507 & 3.67 & 1.40 & 2.00 & 0.20 & 4 & I \\
\hline 901 & NV & UHALDE RANCH & GEORGE & 520601 & 0.75 & 1.40 & 2.00 & 0.20 & 4 & I \\
\hline
\end{tabular}




\begin{tabular}{ccl} 
Cntrl & State & \multicolumn{1}{c}{ Locale } \\
& & \\
901 & NV & UHALDE RANCH \\
901 & NV & UHALDE RANCH \\
901 & NV & UHALDE RANCH \\
901 & NV & UHALDE RANCH \\
901 & NV & UHALDE RANCH \\
901 & NV & UHALDE RANCH \\
901 & NV & UHALDE RANCH \\
901 & NV & UHALDE RANCH \\
901 & NV & UHALDE RANCH \\
901 & NV & UHALDE RANCH \\
901 & NV & UHALDE RANCH \\
902 & NV & URRETIAS RANCH \\
902 & NV & URRETIAS RANCH \\
902 & NV & URRETIAS RANCH \\
902 & NV & URRETIAS RANCH \\
902 & NV & URRETIAS RANCH \\
902 & NV & URRETIAS RANCH \\
902 & NV & URRETIAS RANCH \\
902 & NV & URRETIAS RANCH \\
902 & NV & URRETIAS RANCH \\
902 & NV & URRETIAS RANCH \\
902 & NV & URRETIAS RANCH \\
903 & NV & URSINE \\
903 & NV & URSINE \\
903 & NV & URSINE \\
903 & NV & URSINE \\
903 & NV & URSINE \\
904 & NV & VIGO \\
904 & NV & VIGO \\
904 & NV & VIGO \\
904 & NV & VIGO \\
904 & NV & VIGO \\
904 & NV & VIGO \\
& & \\
& & \\
9 &
\end{tabular}

Event

YYMMDD $\mathrm{H} 12 \quad \mathrm{H} 12 \mathrm{D}$

$\begin{array}{llll}\text { TA } & \text { TAD } & \text { NP } & \text { Orig }\end{array}$

\begin{tabular}{|c|c|c|c|c|c|c|}
\hline GRABLE & 530525 & 0.80 & 1.40 & 2.00 & 0.20 & 4 \\
\hline HOOD & 570705 & 0.09 & 2.14 & 4.36 & 0.44 & 2 \\
\hline NANCY & 530324 & 7.39 & 1.00 & 3.75 & 0.37 & 1 \\
\hline OWENS & 570725 & 0.23 & 1.24 & 4.00 & 0.40 & 3 \\
\hline PLATTE & 620414 & 0.56 & 1.00 & 4.78 & 0.48 & 1 \\
\hline SCHOONER & 681208 & 1.27 & 1.37 & 3.97 & 0.40 & 32 \\
\hline SEDAN & 620706 & 2.38 & 1.16 & 4.06 & 0.41 & 4 \\
\hline SHASTA & 570818 & 0.15 & 2.13 & 7.00 & 0.70 & 2 \\
\hline SUGAR & 511119 & 3.09 & 1.40 & 2.00 & 0.20 & 4 \\
\hline TURK & 550307 & 8.23 & 1.40 & 11.07 & 1.11 & 4 \\
\hline UNCLE & 511129 & 2.76 & 1.40 & 3.87 & 0.39 & 4 \\
\hline APPLE-2 & 550505 & 0.44 & 1.40 & 6.70 & 0.67 & 3 \\
\hline DIABLO & 570715 & 10.17 & 1.40 & 11.73 & 1.17 & 4 \\
\hline DOPPLER & 570823 & 1.00 & 1.40 & 9.08 & 0.91 & 4 \\
\hline EASY & 520507 & 9.49 & 1.40 & 2.76 & 0.28 & 4 \\
\hline GRABLE & 530525 & 0.57 & 1.40 & 2.57 & 0.26 & 4 \\
\hline HOOD & 570705 & 0.50 & 1.40 & 7.12 & 0.71 & 4 \\
\hline NANCY & 530324 & 9.57 & 1.40 & 5.33 & 0.53 & 4 \\
\hline SCHOONER & 681208 & 0.08 & 1.40 & 6.78 & 0.68 & 4 \\
\hline SEDAN & 620706 & 0.56 & 1.40 & 7.30 & 0.73 & 4 \\
\hline TURK & 550307 & 1.00 & 1.40 & 13.84 & 1.38 & 4 \\
\hline UNCLE & 511129 & 0.60 & 1.40 & 6.00 & 0.60 & 4 \\
\hline APPLE-1 & 550329 & 0.24 & 1.00 & 4.46 & 0.45 & 1 \\
\hline FOX & 520525 & 10.60 & 1.40 & 10.41 & 1.04 & 4 \\
\hline SMALL BOY & 620714 & 0.12 & 1.40 & 11.87 & 1.78 & 4 \\
\hline TESLA & 550301 & 0.06 & 1.00 & 11.50 & 1.73 & 1 \\
\hline TURK & 550307 & 0.31 & 1.00 & 14.00 & 2.10 & 1 \\
\hline ANNIE & 530317 & 7.42 & 1.40 & 2.09 & 0.21 & 4 \\
\hline ESS & 550323 & 0.57 & 1.40 & 7.02 & 0.70 & 3 \\
\hline HARIRY & 530519 & 83.74 & 1.40 & 2.10 & 0.21 & 4 \\
\hline HORNET & 550312 & 0.52 & 1.40 & 7.18 & 0.72 & 4 \\
\hline PRISCILLA & 570624 & 1.00 & 1.00 & 6.84 & 1.03 & 1 \\
\hline SIMON & 530425 & 3.00 & 1.40 & 7.36 & 0.74 & 4 \\
\hline
\end{tabular}




\begin{tabular}{|c|c|c|c|c|c|c|c|c|c|c|}
\hline Cntrl & State & Locale & Event & YYMMDD & $\mathrm{H} 12$ & $\mathrm{H} 12 \mathrm{D}$ & TA & TAD & NP & Orig \\
\hline 904 & NV & VIGO & SMOKY & 570831 & 4.17 & 3.30 & 4.20 & 0.42 & 5 & $\mathrm{R}$ \\
\hline 904 & NV & VIGO & TESLA & 550301 & 4.83 & 1.80 & 5.72 & 0.57 & 4 & I \\
\hline 904 & NV & VIGO & TURK & 550307 & 0.43 & 1.40 & 10.05 & 1.00 & 3 & I \\
\hline 633 & NV & VIRGINIA CITY & BOLTZMANN & 570528 & 0.66 & 1.40 & 13.92 & 1.39 & 4 & I \\
\hline 959 & NV & WADSWORTH & BOLTZMANN & 570528 & 3.12 & 1.00 & 14.00 & 1.40 & 1 & $\mathrm{R}$ \\
\hline 905 & NV & WALCH PINE CREEK RAN & APPLE-2 & 550505 & 4.68 & 1.40 & 3.23 & 0.32 & 4 & I \\
\hline 905 & NV & WALCH PINE CREEK RAN & DIABLO & 570715 & 1.47 & 1.21 & 7.20 & 0.72 & 4 & I \\
\hline 905 & NV & WALCH PINE CREEK RAN & EASY & 520507 & 4.63 & 1.40 & 2.00 & 0.20 & 4 & I \\
\hline 905 & NV & WALCH PINE CREEK RAN & GEORGE & 520601 & 0.96 & 1.40 & 2.00 & 0.20 & 4 & I \\
\hline 905 & NV & WALCH PINE CREEK RAN & GRABLE & 530525 & 0.82 & 1.40 & 2.00 & 0.20 & 4 & I \\
\hline 905 & NV & WALCH PINE CREEK RAN & HOOD & 570705 & 0.49 & 2.14 & 4.00 & 0.40 & 4 & I \\
\hline 905 & NV & WALCH PINE CREEK RAN & NANCY & 530324 & 8.65 & 1.06 & 3.53 & 0.35 & 4 & I \\
\hline 905 & NV & WALCH PINE CREEK RAN & OWENS & 570725 & 0.42 & 1.13 & 3.54 & 0.35 & 4 & I \\
\hline 905 & NV & WALCH PINE CREEK RAN & PLATTE & 620414 & 0.33 & 1.40 & 4.44 & 0.44 & 4 & I \\
\hline 905 & NV & WALCH PINE CREEK RAN & SCHOONER & 681208 & 2.52 & 1.28 & 3.75 & 0.37 & 7 & $\mathrm{R}$ \\
\hline 905 & NV & WALCH PINE CREEK RAN & SEDAN & 620706 & 1.78 & 1.01 & 3.72 & 0.37 & 2 & $\mathrm{R}$ \\
\hline 905 & NV & WALCH PINE CREEK RAN & SHASTA & 570818 & 0.11 & 1.00 & 7.00 & 0.70 & 1 & $\mathrm{R}$ \\
\hline 905 & NV & WALCH PINE CREEK RAN & SUGAR & 511119 & 3.33 & 1.40 & 2.00 & 0.20 & 4 & I \\
\hline 905 & NV & WALCH PINE CREEK RAN & TURK & 550307 & 8.72 & 1.40 & 10.85 & 1.09 & 4 & I \\
\hline 905 & NV & WALCH PINE CREEK RAN & UNCLE & 511129 & 4.13 & 1.40 & 3.34 & 0.33 & 4 & I \\
\hline 906 & NV & WARM SPRINGS & APPLE-2 & 550505 & 0.39 & 2.37 & 4.31 & 0.43 & 2 & $\mathrm{R}$ \\
\hline 906 & NV & WARM SPRINGS & BANEBERRY & 701218 & 0.13 & 1.61 & 8.06 & 0.81 & 47 & $\mathrm{R}$ \\
\hline 906 & NV & WARM SPRINGS & BOLTZMANN & 570528 & 2.26 & 2.21 & 4.31 & 0.43 & 34 & $\mathrm{R}$ \\
\hline 906 & NV & WARM SPRINGS & BUGGY & 680312 & 0.13 & 2.39 & 4.50 & 0.68 & 180 & $\mathrm{R}$ \\
\hline 906 & NV & WARM SPRINGS & DANNY BOY & 620305 & 0.06 & 2.01 & 2.79 & 0.28 & 18 & $\mathrm{R}$ \\
\hline 906 & NV & WARM SPRINGS & GALILEO & 570902 & 2.24 & 1.09 & 12.00 & 1.20 & 5 & $\mathrm{R}$ \\
\hline 906 & NV & WARM SPRINGS & GEORGE & 520601 & 2.54 & 1.00 & 5.08 & 0.51 & 1 & $\mathrm{R}$ \\
\hline 906 & NV & WARM SPRINGS & HOW & 520605 & 2.69 & 1.35 & 4.00 & 0.40 & 4 & $\mathrm{R}$ \\
\hline 906 & NV & WARM SPRINGS & JOHNIE BOY & 620711 & 0.25 & 1.80 & 4.50 & 0.68 & 10 & $\mathrm{R}$ \\
\hline 906 & NV & WARM SPRINGS & LEA & 581013 & 0.31 & 1.52 & 10.83 & 1.08 & 3 & $\mathrm{R}$ \\
\hline 906 & NV & WARM SPRINGS & NANCY & 530324 & 0.68 & 1.95 & 4.26 & 0.43 & 8 & $\mathrm{R}$ \\
\hline 906 & NV & WARM SPRINGS & OWENS & 570725 & 0.07 & 1.68 & 4.50 & 0.45 & 3 & $\mathrm{R}$ \\
\hline 906 & NV & WARM SPRINGS & PALANQUIN & 650414 & 0.25 & 2.37 & 8.59 & 0.86 & 17 & $\mathrm{R}$ \\
\hline
\end{tabular}




\begin{tabular}{ccl} 
Cntrl & State & \multicolumn{1}{c}{ Locale } \\
906 & NV & WARM SPRINGS \\
906 & NV & WARM SPRINGS \\
906 & NV & WARM SPRINGS \\
906 & NV & WARM SPRINGS \\
906 & NV & WARM SPRINGS \\
956 & NV & WARM SPRINGS NORTH \\
956 & NV & WARM SPRINGS NORTH \\
956 & NV & WARM SPRINGS NORTH \\
956 & NV & WARM SPRINGS NORTH \\
956 & NV & WARM SPRINGS NORTH \\
907 & NV & WARM SPRINGS RANCH \\
907 & NV & WARM SPRINGS RANCH \\
907 & NV & WARM SPRINGS RANCH \\
907 & NV & WARM SPRINGS RANCH \\
907 & NV & WARM SPRINGS RANCH \\
907 & NV & WARM SPRINGS RANCH \\
907 & NV & WARM SPRINGS RANCH \\
907 & NV & WARM SPRINGS RANCH \\
908 & NV & WATERTOWN \\
908 & NV & WATERTOWN \\
908 & NV & WATERTOWN \\
908 & NV & WATERTOWN \\
908 & NV & WATERTOWN \\
908 & NV & WATERTOWN \\
67 & NV & WEED HEIGHTS \\
909 & NV & WHIPPLE RANCH \\
909 & NV & WHIPPLE RANCH \\
909 & NV & WHIPPLE RANCH \\
909 & NV & WHIPPLE RANCH \\
909 & NV & WHIPPLE RANCH \\
909 & NV & WHIPPLE RANCH \\
909 & NV & WHIPPLE RANCH \\
909 & NV & WHIPPIE RANCH \\
& & \\
& & \\
& & \\
&
\end{tabular}

Event

YYMMDD $\mathrm{H} 12 \quad \mathrm{H} 12 \mathrm{D}$

TA

TAD NP Orig

$\begin{array}{lrrrrrrl}\text { SCHOONER } & 681208 & 0.13 & 1.66 & 8.60 & 0.86 & 67 & \mathrm{R} \\ \text { SHASTA } & 570818 & 0.55 & 2.44 & 6.00 & 0.90 & 13 & \mathrm{R} \\ \text { SUGAR } & 511119 & 0.59 & 1.40 & 2.00 & 0.20 & 4 & \mathrm{I} \\ \text { TURK } & 550307 & 4.47 & 1.24 & 10.49 & 1.05 & 2 & \mathrm{R} \\ \text { WHITNEY } & 570923 & 0.20 & 1.00 & 13.00 & 1.95 & 1 & \mathrm{R} \\ \text { APPLE-2 } & 550505 & 1.36 & 1.40 & 9.05 & 0.91 & 4 & \mathrm{I} \\ \text { DOPPLER } & 570823 & 0.11 & 1.40 & 14.00 & 1.40 & 4 & \mathrm{I} \\ \text { OWENS } & 570725 & 0.42 & 1.40 & 10.29 & 1.03 & 4 & \mathrm{I} \\ \text { SUGAR } & 511119 & 0.51 & 1.40 & 5.00 & 0.50 & 4 & \mathrm{I} \\ \text { UNCLE } & 511129 & 0.40 & 1.40 & 8.00 & 0.80 & 4 & \mathrm{I} \\ \text { ANNIE } & 530317 & 2.65 & 1.61 & 3.00 & 0.30 & 3 & \mathrm{R} \\ \text { BANDICOOT } & 621019 & 0.08 & 1.00 & 2.00 & 0.20 & 1 & \mathrm{R} \\ \text { CLIMAX } & 530604 & 0.25 & 2.42 & 4.21 & 0.42 & 2 & \mathrm{R} \\ \text { ESS } & 550323 & 0.58 & 1.40 & 5.91 & 0.59 & 4 & \mathrm{I} \\ \text { HORNET } & 550312 & 4.20 & 1.01 & 6.39 & 0.64 & 2 & \mathrm{R} \\ \text { SIMON } & 530425 & 1.40 & 1.62 & 4.07 & 0.41 & 9 & \mathrm{R} \\ \text { SMOKY } & 570831 & 1.44 & 1.34 & 7.41 & 0.74 & 3 & \mathrm{R} \\ \text { ZUCCHINI } & 550515 & 9.00 & 1.20 & 2.70 & 0.27 & 8 & \mathrm{R} \\ \text { BANDICOOT } & 621019 & 0.17 & 1.40 & 1.12 & 0.11 & 4 & \mathrm{I} \\ \text { DIABLO } & 570715 & 13.02 & 2.17 & 3.00 & 0.30 & 83 & \mathrm{R} \\ \text { DOPPLER } & 570823 & 0.10 & 1.40 & 1.07 & 0.11 & 3 & \mathrm{I} \\ \text { SMOKY } & 570831 & 0.21 & 1.04 & 2.30 & 0.34 & 2 & \mathrm{R} \\ \text { WHITNEY } & 570923 & 0.09 & 1.00 & 1.09 & 0.11 & 1 & \mathrm{R} \\ \text { WILSON } & 570618 & 0.77 & 2.61 & 5.22 & 0.52 & 44 & \mathrm{R} \\ \text { KEPLER } & 570724 & 0.73 & 1.40 & 15.00 & 1.50 & 4 & \mathrm{I} \\ \text { APPLE-1 } & 550329 & 1.67 & 1.50 & 2.91 & 0.29 & 4 & \mathrm{I} \\ \text { DIABLO } & 570715 & 2.03 & 1.83 & 6.21 & 0.62 & 14 & \mathrm{R} \\ \text { EASY } & 520507 & 0.83 & 1.40 & 0.86 & 0.09 & 4 & \mathrm{I} \\ \text { FOX } & 520525 & 4.53 & 1.00 & 6.19 & 0.62 & 1 & \mathrm{R} \\ \text { HARRY } & 530519 & 1.35 & 1.32 & 2.62 & 0.26 & 4 & \mathrm{I} \\ \text { PIN STRIPE } & 660425 & 0.11 & 1.81 & 4.34 & 0.43 & 8 & \mathrm{R} \\ \text { SCHOONER } & 681208 & 0.06 & 1.00 & 4.00 & 0.40 & 1 & \mathrm{R} \\ \text { SHASTA } & 570818 & 0.43 & 1.61 & 28.50 & 4.28 & 3 & \mathrm{R}\end{array}$




\begin{tabular}{|c|c|c|c|c|c|c|c|c|c|c|}
\hline Cntrl & State & Locale & Event & YYMMDD & $\mathrm{H} 12$ & $\mathrm{H} 12 \mathrm{D}$ & $\mathrm{TA}$ & $\mathrm{TAD}$ & NP & Orig \\
\hline 909 & NV & WHIPPLE RANCH & TESLA & 550301 & 0.75 & 1.40 & 6.00 & 0.60 & 4 & I \\
\hline 909 & NV & WHIPPLE RANCH & TURK & 550307 & 0.42 & 1.40 & 10.48 & 1.05 & 3 & $I$ \\
\hline 909 & NV & WHIPPLE RANCH & UNCLE & 511129 & 0.45 & 1.40 & 3.00 & 0.30 & 4 & I \\
\hline 910 & NV & WHITNEY & BADGER & 530418 & 1.08 & 1.80 & 3.00 & 0.30 & 4 & $\mathrm{R}$ \\
\hline 910 & NV & WHITNEY & BEE & 550322 & 0.49 & 1.35 & 3.26 & 0.33 & 3 & $\mathrm{R}$ \\
\hline 68 & NV & YERINGTON & KEPLER & 570724 & 0.85 & 1.40 & 15.00 & 1.50 & 4 & I \\
\hline 911 & UT & ADAMSVILLE & FOX & 520525 & 2.12 & 1.40 & 14.18 & 1.42 & 4 & $\mathrm{I}$ \\
\hline 911 & UT & ADAMSVILLE & MET & 550415 & 5.01 & 1.00 & 5.92 & 0.59 & 1 & $\mathrm{R}$ \\
\hline 911 & UT & ADAMSVILLE & SMALL BOY & 620714 & 0.09 & 1.16 & 20.00 & 3.00 & 6 & $\mathrm{R}$ \\
\hline 911 & UT & ADAMSVILLE & SMOKY & 570831 & 0.08 & 1.02 & 8.00 & 1.20 & 2 & $\mathrm{R}$ \\
\hline 911 & UT & ADAMSVILLE & TURK & 550307 & 0.36 & 1.00 & 17.00 & 2.55 & 1 & $\mathrm{R}$ \\
\hline 212 & UT & ALTAMONT & SMALL BOY & 620714 & 0.55 & 1.40 & 40.00 & 6.00 & 4 & I \\
\hline 271 & UT & ALTON & APPLE-1 & 550329 & 0.60 & 1.00 & 7.00 & 0.70 & 1 & $\mathrm{R}$ \\
\hline $27 !$ & UT & ALTON & HARRY & 530519 & 14.45 & 1.92 & 5.41 & 0.54 & 4 & I \\
\hline 271 & UT & ALTON & MORGAN & 571007 & 0.12 & 1.40 & 11.50 & 1.15 & 4 & I \\
\hline 271 & UT & ALTON & PRISCILLA & 570624 & 0.76 & 1.00 & 10.00 & 1.00 & 1 & $\mathrm{R}$ \\
\hline 912 & UT & ANDERSON JUNCTION & ANNIE & 530317 & 0.19 & 1.35 & 3.14 & 0.31 & 2 & $\mathrm{R}$ \\
\hline 912 & UT & ANDERSON JUNCTION & HARRY & 530519 & 33.30 & 1.37 & 4.20 & 0.42 & 4 & $\mathrm{R}$ \\
\hline 912 & UT & ANDERSON JUNCTION & MORGAN & 571007 & 0.54 & 1.28 & 8.61 & 0.86 & 3 & $\mathrm{R}$ \\
\hline 912 & UT & ANDERSON JUNCTION & PRISCILLA & 570624 & 1.48 & 1.47 & 9.30 & 0.93 & 7 & $\mathrm{R}$ \\
\hline 912 & UT & ANDERSON JUNCTION & SMOKY & 570831 & 15.41 & 1.19 & 6.28 & 0.63 & 7 & $\mathrm{R}$ \\
\hline 912 & UT & ANDERSON JUNCTION & TESLA & 550301 & 1.05 & 1.42 & 12.15 & 1.22 & 4 & $\mathrm{I}$ \\
\hline 912 & UT & ANDERSON JUNCTION & ZUCCHINI & 550515 & 1.16 & 1.00 & 4.08 & 0.41 & 1 & $\mathrm{R}$ \\
\hline 360 & UT & ANNABELLA & APPLE-2 & 550505 & 0.46 & 1.40 & 13.29 & 1.33 & 4 & I \\
\hline 242 & UT & ANTIMONY & FOX & 520525 & 1.19 & 1.40 & 15.00 & 1.50 & 4 & I \\
\hline 242 & UT & ANTIMONY & SMOKY & 570831 & 10.00 & 1.40 & 12.26 & 1.23 & 4 & I \\
\hline 365 & UT & AURORA & SMALL BOY & 620714 & 0.10 & 1.00 & 27.00 & 4.05 & 1 & $\mathrm{R}$ \\
\hline 913 & UT & BEAR VALLEY JUNCTION & FOX & 520525 & 1.37 & 1.40 & 14.78 & 1.48 & 4 & 1 \\
\hline 913 & UT & BEAR VALLEY JUNCTION & MET & 550415 & 0.37 & 1.40 & 5.00 & 0.50 & 3 & I \\
\hline 913 & UT & BEAR VALLEY JUNCTION & SMOKY & 570831 & 11.52 & 1.45 & 12.07 & 1.21 & 9 & $\mathrm{R}$ \\
\hline 122 & UT & BEAVER & FOX & 520525 & 1.58 & 1.40 & 14.66 & 1.47 & 4 & I \\
\hline 122 & UT & BEAVER & MET & 550415 & 5.91 & 1.35 & 5.97 & 0.60 & 3 & $\mathrm{R}$ \\
\hline 122 & UT & BEAVER & SMOKY & 570831 & 0.08 & 1.14 & 9.00 & 0.90 & 6 & $\mathrm{R}$ \\
\hline
\end{tabular}




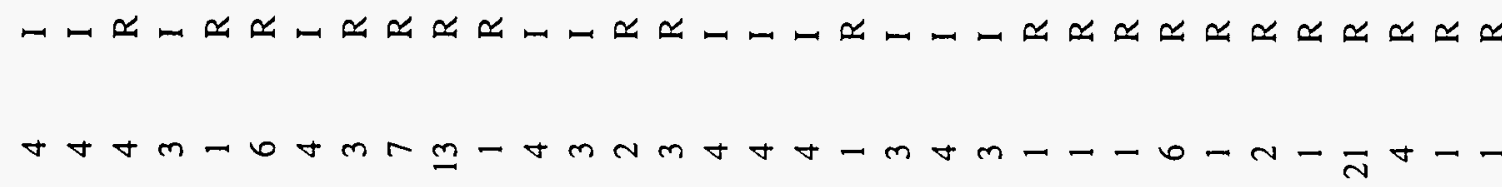

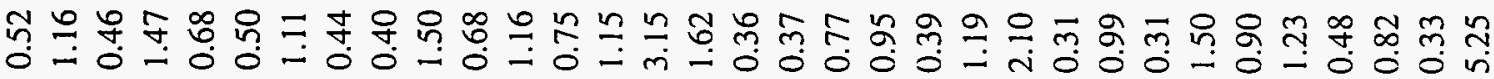

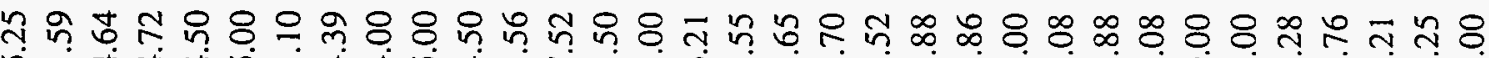

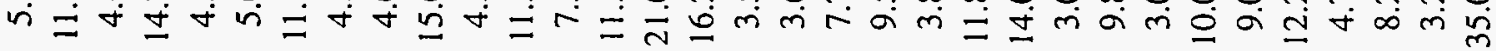

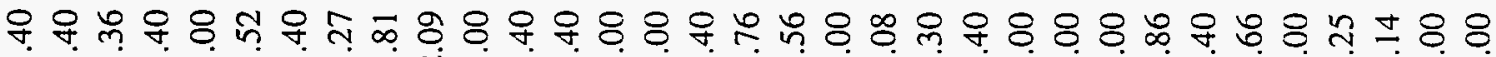

- - - - - - -

沑 苟

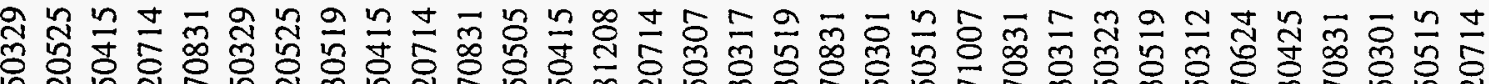

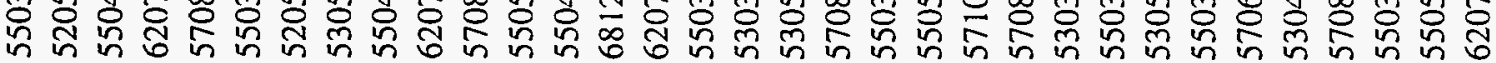

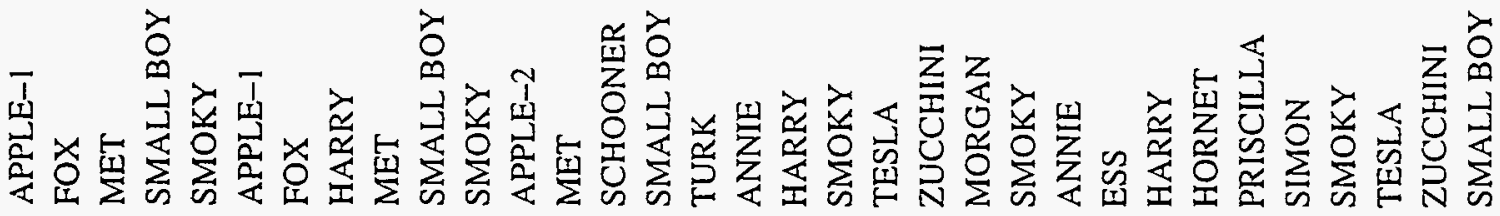

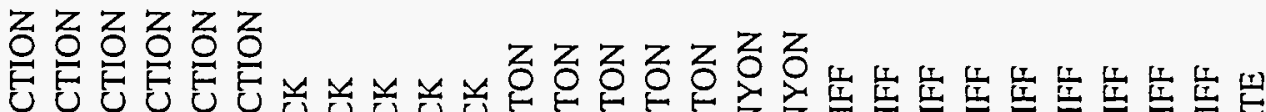

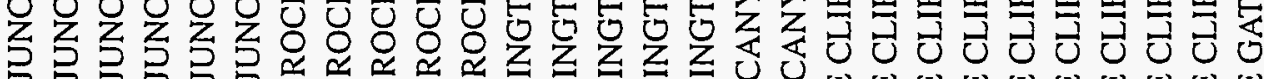

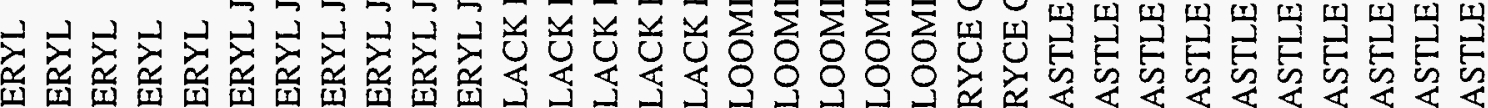

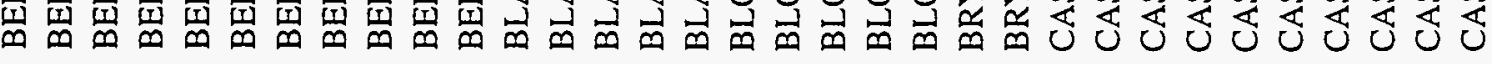

555555555555555555555555555555555

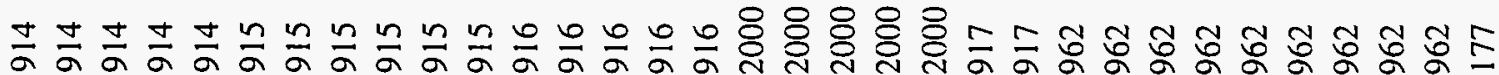




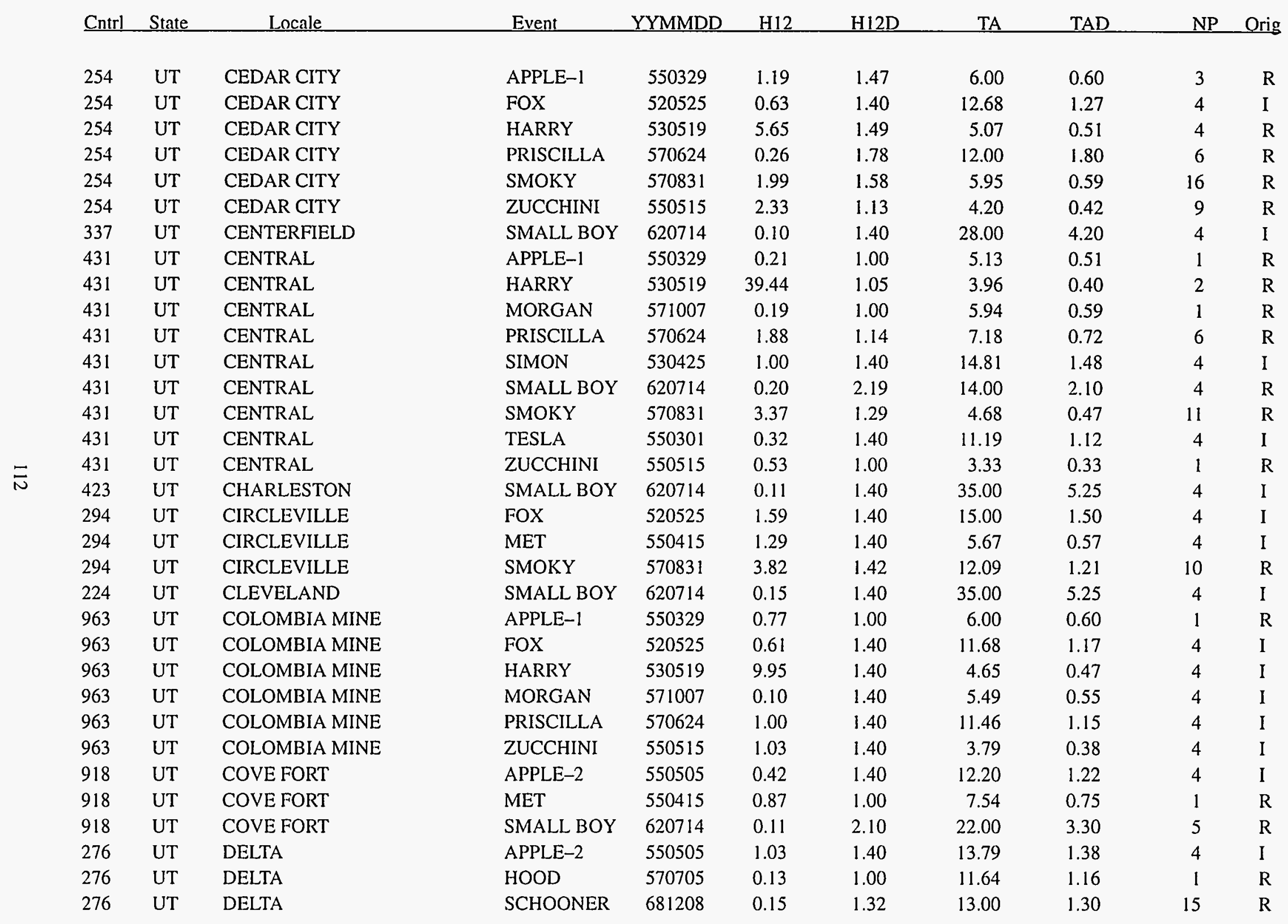




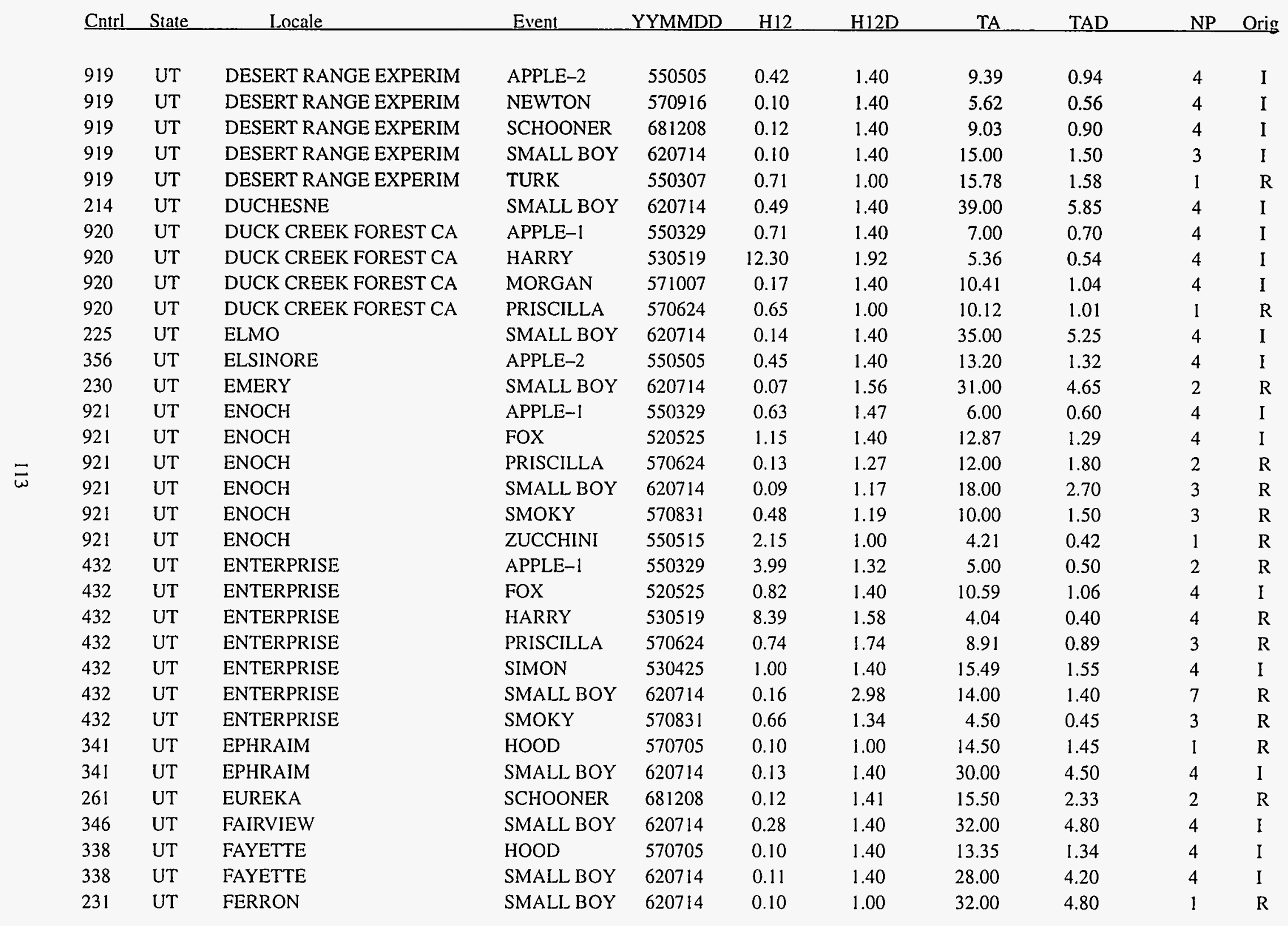




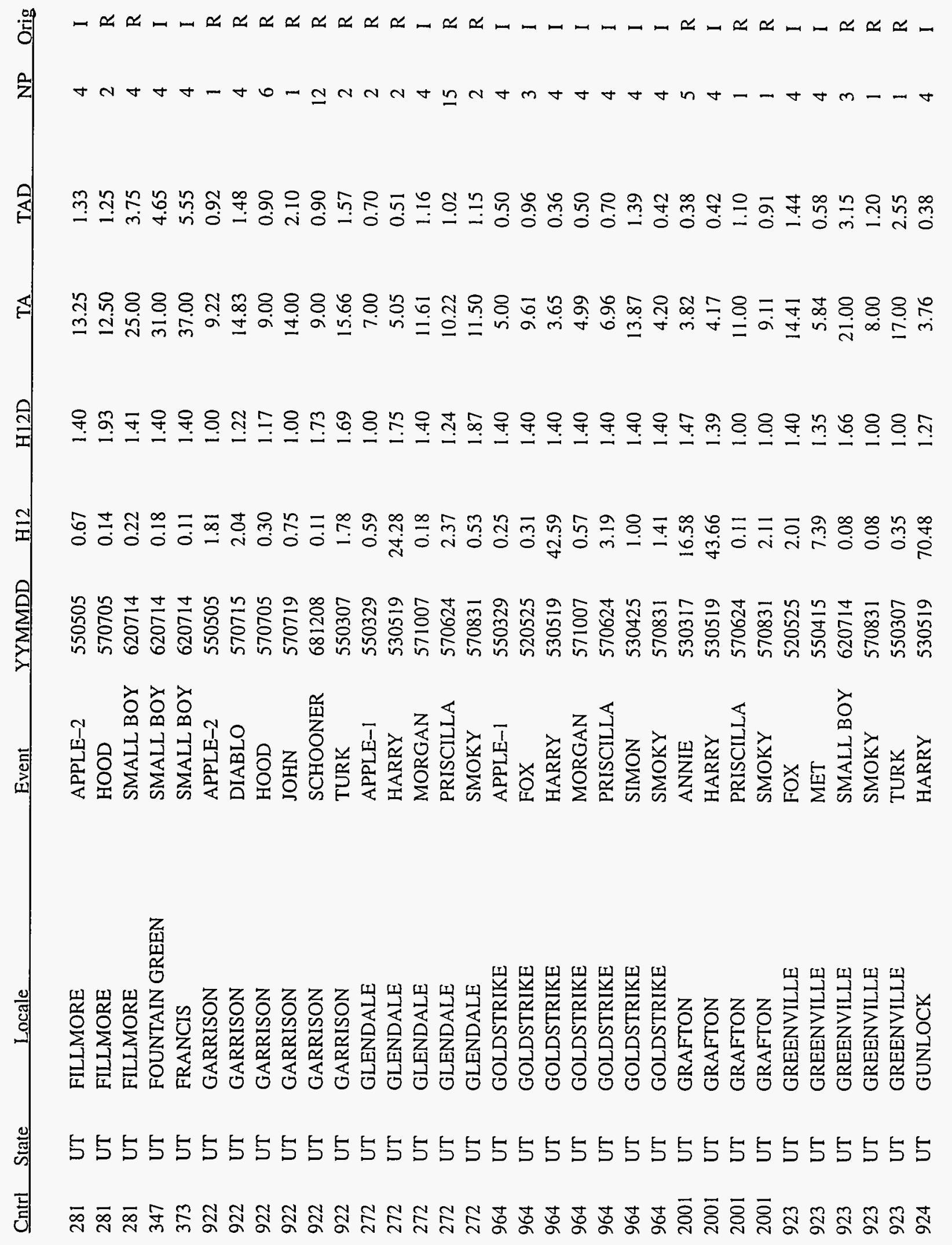




\begin{tabular}{|c|c|c|c|c|c|c|c|c|c|c|}
\hline Cntrl & State & Locale & Event & YYMMDD & $\mathrm{H} 12$ & $\mathrm{H} 12 \mathrm{D}$ & $\mathrm{TA}$ & TAD & NP & Orig \\
\hline 924 & UT & GUNLOCK & MORGAN & 571007 & 0.41 & 1.15 & 6.49 & 0.65 & 4 & I \\
\hline 924 & UT & GUNLOCK & PRISCILLA & 570624 & 1.67 & 1.22 & 7.16 & 0.72 & 7 & $\mathrm{R}$ \\
\hline 924 & UT & GUNLOCK & SIMON & 530425 & 1.00 & 1.40 & 13.84 & 1.38 & 4 & $I$ \\
\hline 924 & UT & GUNLOCK & SMOKY & 570831 & 5.83 & 1.10 & 4.48 & 0.45 & 2 & $\mathrm{R}$ \\
\hline 924 & UT & GUNLOCK & TESLA & 550301 & 0.25 & 1.00 & 10.03 & 1.00 & 1 & $\mathrm{R}$ \\
\hline 339 & UT & GUNNISON & HOOD & 570705 & 0.13 & 1.00 & 13.50 & 1.35 & 1 & $\mathrm{R}$ \\
\hline 339 & UT & GUNNISON & SMALL BOY & 620714 & 0.10 & 1.40 & 28.00 & 4.20 & 4 & $\mathrm{I}$ \\
\hline 925 & UT & HAMILTON FORT & APPLE-1 & 550329 & 2.67 & 1.17 & 6.00 & 0.60 & 3 & $\mathrm{R}$ \\
\hline 925 & UT & HAMILTON FORT & FOX & 520525 & 0.46 & 1.40 & 12.45 & 1.25 & 4 & I \\
\hline 925 & UT & HAMILTON FORT & HARRY & 530519 & 11.58 & 1.15 & 4.96 & 0.50 & 3 & $\mathrm{R}$ \\
\hline 925 & UT & HAMILTON FORT & PRISCILLA & 570624 & 0.36 & 1.69 & 11.11 & 1.11 & 3 & $\mathrm{R}$ \\
\hline 925 & UT & HAMILTON FORT & SMOKY & 570831 & 4.83 & 1.22 & 5.94 & 0.59 & 10 & $\mathrm{R}$ \\
\hline 925 & UT & HAMILTON FORT & ZUCCHINI & 550515 & 1.77 & 1.52 & 4.09 & 0.41 & 2 & $\mathrm{R}$ \\
\hline 926 & UT & HAMLIN VALLEY & FOX & 520525 & 9.15 & 1.40 & 11.18 & 1.12 & 4 & I \\
\hline 926 & UT & HAMLIN VALLEY & MET & 550415 & 0.60 & 1.40 & 5.00 & 0.50 & 3 & I \\
\hline 926 & UT & HAMLIN VALLEY & SMALL BOY* & 620714 & 0.21 & 1.18 & 13.48 & 1.35 & 6 & $\mathrm{R}$ \\
\hline 2002 & UT & HARRISBURG JCT. & ANNIE & 530317 & 7.66 & 1.74 & 3.38 & 0.34 & 2 & $\mathrm{R}$ \\
\hline 2002 & UT & HARRISBURG JCT. & HARRY & 530519 & 45.34 & 1.34 & 3.87 & 0.39 & 7 & $\mathrm{R}$ \\
\hline 2002 & UT & HARRISBURG JCT. & PRISCILLA & 570624 & 0.35 & 1.83 & 10.50 & 1.05 & 3 & $\mathrm{R}$ \\
\hline 2002 & UT & HARRISBURG JCT. & SIMON & 530425 & 1.00 & 1.40 & 13.84 & 1.38 & 3 & I \\
\hline 2002 & UT & HARRISBURG JCT. & SMOKY & 570831 & 5.53 & 1.35 & 7.55 & 0.75 & 12 & $\mathrm{R}$ \\
\hline 2002 & UT & HARRISBURG JCT. & TESLA & 550301 & 0.33 & 1.00 & 11.00 & 1.10 & 1 & $\mathrm{R}$ \\
\hline 2002 & UT & HARRISBURG JCT. & ZUCCHINI & 550515 & 1.10 & 1.40 & 4.02 & 0.40 & 4 & I \\
\hline 239 & UT & HATCH & PRISCILLA & 570624 & 0.33 & 1.00 & 12.00 & 1.20 & 1 & $\mathrm{R}$ \\
\hline 239 & UT & HATCH & SMOKY & 570831 & 1.22 & 1.22 & 11.89 & 1.19 & 3 & $\mathrm{R}$ \\
\hline 424 & UT & HEBER CITY & SMALL BOY & 620714 & 0.11 & 1.40 & 36.00 & 5.40 & 4 & I \\
\hline 178 & UT & HELPER & SMALL BOY & 620714 & 0.18 & 1.40 & 35.00 & 5.25 & 4 & I \\
\hline 180 & UT & HIAWATHA & SMALL BOY & 620714 & 0.54 & 1.40 & 34.00 & 5.10 & 4 & I \\
\hline 2012 & UT & HILLDALE & ANNIE & 530317 & 0.15 & 1.40 & 4.42 & 0.44 & 4 & I \\
\hline 2012 & UT & HILLDALE & HARRY & 530519 & 64.70 & 1.40 & 4.08 & 0.41 & 4 & $I$ \\
\hline 2012 & UT & HILLDALE & TESL_A & 550301 & 0.75 & 1.40 & 11.92 & 1.19 & 4 & I \\
\hline 928 & UT & HILLSDALE & SMOKY & 570831 & 3.05 & 1.20 & 11.91 & 1.19 & 4 & $\mathrm{R}$ \\
\hline 277 & UT & HINCKLEY & APPLE-2 & 550505 & 1.03 & 1.40 & 13.58 & 1.36 & 4 & I \\
\hline
\end{tabular}




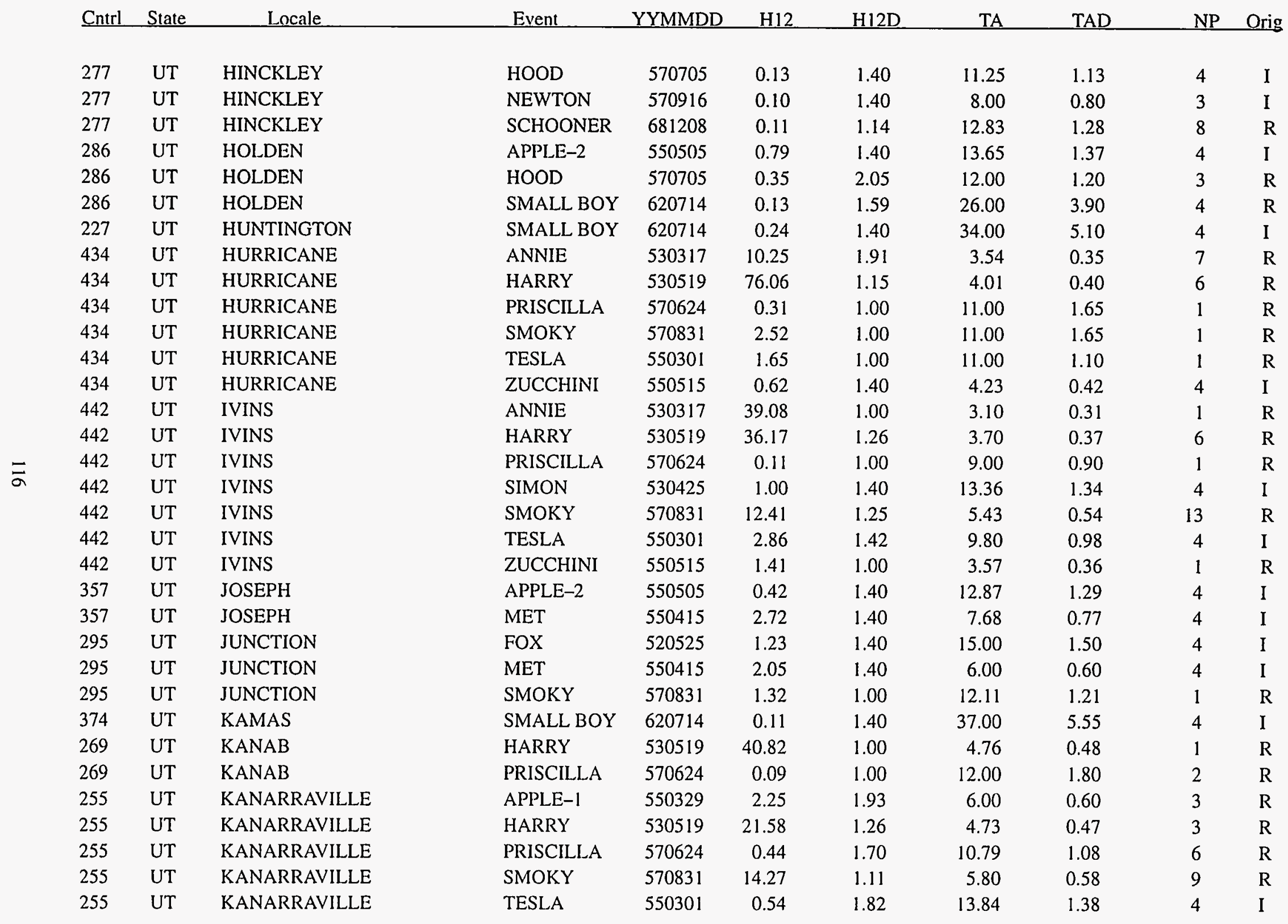




\begin{tabular}{|c|c|c|c|c|c|c|c|c|c|c|}
\hline Cntrl & State & Locale & Event & YYMMDD & $\mathrm{H} 12$ & $\mathrm{H} 12 \mathrm{D}$ & $\mathrm{TA}$ & TAD & NP & Orig \\
\hline 255 & UT & KANARRAVILLE & ZUCCHINI & 550515 & 1.92 & 1.00 & 4.00 & 0.40 & 1 & $\mathrm{R}$ \\
\hline 282 & UT & KANOSH & APPLE-2 & 550505 & 0.52 & 1.40 & 12.78 & 1.28 & 4 & I \\
\hline 282 & UT & KANOSH & HOOD & 570705 & 0.07 & 1.65 & 12.00 & 1.20 & 2 & $\mathrm{R}$ \\
\hline 282 & UT & KANOSH & MET & 550415 & 0.53 & 1.40 & 8.64 & 0.86 & 4 & $I$ \\
\hline 282 & UT & KANOSH & SMALL BOY & 620714 & 0.10 & 1.00 & 24.00 & 3.60 & 4 & I \\
\hline 296 & UT & KINGSTON & FOX & 520525 & 1.24 & 1.40 & 15.00 & 1.50 & 4 & I \\
\hline 296 & UT & KINGSTON & MET & 550415 & 1.36 & 1.40 & 6.00 & 0.60 & 4 & I \\
\hline 296 & UT & KINGSTON & SMOKY & 570831 & 8.93 & 1.42 & 12.04 & 1.20 & 4 & I \\
\hline 435 & UT & LA VERKIN & ANNIE & 530317 & 1.77 & 1.62 & 3.42 & 0.34 & 3 & $\mathrm{R}$ \\
\hline 435 & UT & LA VERKIN & HARRY & 530519 & 65.32 & 1.32 & 4.08 & 0.41 & 8 & $R$ \\
\hline 435 & UT & LA VERKIN & MORGAN & 571007 & 0.14 & 1.24 & 9.69 & 0.97 & 4 & I \\
\hline 435 & UT & LA VERKIN & PRISCILLA & 570624 & 0.40 & 1.48 & 10.23 & 1.02 & 3 & $\mathrm{R}$ \\
\hline 435 & UT & LA VERKIN & SMOKY & 570831 & 2.53 & 1.00 & 11.00 & 1.65 & 2 & $\mathrm{R}$ \\
\hline 435 & UT & LA VERKIN & TESLA & 550301 & 1.66 & 1.00 & 11.64 & 1.16 & 2 & $\mathrm{R}$ \\
\hline 435 & UT & LA VERKIN & ZUCCHINI & 550515 & 0.73 & 1.40 & 4.20 & 0.42 & 4 & I \\
\hline 278 & UT & LEAMINGTON & APPLE-2 & 550505 & 1.03 & 1.40 & 14.84 & 1.48 & 3 & I \\
\hline 278 & UT & LEAMINGTON & HOOD & 570705 & 0.10 & 1.40 & 12.00 & 1.20 & 4 & $I$ \\
\hline 436 & UT & LEEDS & ANNIE & 530317 & 2.04 & 1.57 & 3.27 & 0.33 & 4 & I \\
\hline 436 & UT & LEEDS & HARRY & 530519 & 31.10 & 1.41 & 4.07 & 0.41 & 4 & $\mathrm{R}$ \\
\hline 436 & UT & LEEDS & MORGAN & 571007 & 0.70 & 1.17 & 9.14 & 0.91 & 2 & $\mathrm{R}$ \\
\hline 436 & UT & LEEDS & PRISCILLA & 570624 & 1.36 & 1.92 & 9.84 & 0.98 & 2 & $\mathrm{R}$ \\
\hline 436 & UT & LEEDS & SMOKY & 570831 & 16.56 & 1.13 & 6.80 & 0.68 & 8 & $\mathrm{R}$ \\
\hline 436 & UT & LEEDS & TESLA & 550301 & 1.16 & 1.51 & 11.62 & 1.16 & 3 & $I$ \\
\hline 436 & UT & LEEDS & ZUCCHINI & 550515 & 1.00 & 1.40 & 4.08 & 0.41 & 4 & I \\
\hline 263 & UT & LEVAN & HOOD & 570705 & 0.19 & 1.00 & 13.50 & 1.35 & 1 & $\mathrm{R}$ \\
\hline 263 & UT & LEVAN & SMALL BOY & 620714 & 0.11 & 1.40 & 29.00 & 4.35 & 4 & I \\
\hline 929 & UT & LONG VALLEY JUNCTION & APPLE-1 & 550329 & 0.62 & 1.40 & 7.00 & 0.70 & 4 & I \\
\hline 929 & UT & LONG VALLEY JUNCTION & HARRY & 530519 & 21.81 & 1.92 & 5.50 & 0.55 & 2 & $\mathrm{R}$ \\
\hline 929 & UT & LONG VALLEY JUNCTION & MORGAN & 571007 & 0.12 & 1.40 & 10.93 & 1.09 & 4 & I \\
\hline 929 & UT & LONG VALLEY JUNCTION & PRISCILLA & 570624 & 0.77 & 1.47 & 10.14 & 1.01 & 2 & $\mathrm{R}$ \\
\hline 929 & UT & LONG VALLEY JUNCTION & SMOKY & 570831 & 0.26 & 1.12 & 12.00 & 1.20 & 3 & $\mathrm{R}$ \\
\hline 930 & UT & LUND & FOX & 520525 & 5.64 & 1.40 & 12.47 & 1.25 & 4 & I \\
\hline 930 & UT & LUND & MET & 550415 & 5.61 & 1.24 & 5.00 & 0.50 & 5 & $\mathrm{R}$ \\
\hline
\end{tabular}




\begin{tabular}{|c|c|c|c|c|c|c|c|c|c|c|}
\hline Cntrl & State & Locale & Event & YYMMDD & $\mathrm{H} 12$ & $\mathrm{H} 12 \mathrm{D}$ & $\mathrm{TA}$ & TAD & NP & Orig \\
\hline 279 & UT & LYNNDYL & A.PPLE-2 & 550505 & 1.05 & 1.40 & 14.77 & 1.48 & 4 & I \\
\hline 279 & UT & LYNNDYL & HOOD & 570705 & 0.10 & 1.40 & 12.00 & 1.20 & 4 & I \\
\hline 279 & UT & LYNNDYL & NEWTON & 570916 & 0.10 & 1.40 & 8.00 & 0.80 & 3 & I \\
\hline 279 & UT & LYNNDYL & SCHOONER & 681208 & 0.29 & 1.24 & 13.00 & 1.30 & 3 & $\mathrm{R}$ \\
\hline 931 & UT & MANDERFIELD & FOX & 520525 & 0.98 & 1.40 & 14.96 & 1.50 & 4 & I \\
\hline 931 & UT & MANDERFIELD & MET & 550415 & 2.41 & 1.00 & 6.00 & 0.60 & 1 & $\mathrm{R}$ \\
\hline 931 & UT & MANDERFIELD & SMALL BOY & 620714 & 0.08 & 1.00 & 21.00 & 3.15 & 3 & $\mathbf{R}$ \\
\hline 931 & UT & MANDERFIELD & SMOKY & 570831 & 0.07 & 1.28 & 10.00 & 1.50 & 5 & $\mathrm{R}$ \\
\hline 342 & UT & MANTI & HOOD & 570705 & 0.07 & 1.31 & 14.00 & 1.40 & 2 & $\mathrm{R}$ \\
\hline 342 & UT & MANTI & SMALL BOY & 620714 & 0.12 & 1.40 & 30.00 & 4.50 & 4 & I \\
\hline 419 & UT & MAPLETON & SMALL BOY & 620714 & 0.27 & 2.19 & 33.00 & 4.95 & 4 & $R$ \\
\hline 298 & UT & MARYSVALE & FOX & 520525 & 0.41 & 1.40 & 15.00 & 1.50 & 4 & I \\
\hline 298 & UT & MARYSVALE & MET & 550415 & 7.39 & 1.40 & 6.68 & 0.67 & 4 & I \\
\hline 298 & UT & MARYSVALE & SMOKY & 570831 & 0.16 & 1.51 & 12.03 & 1.20 & 4 & $\mathrm{R}$ \\
\hline 343 & UT & MAYFIELD & SMALL BOY & 620714 & 0.10 & 1.40 & 29.00 & 4.35 & 4 & I \\
\hline 283 & UT & MEADOW & APPLE-2 & 550505 & 0.60 & 1.40 & 12.95 & 1.29 & 4 & I \\
\hline 283 & UT & MEADOW & HOOD & 570705 & 0.10 & 1.35 & 12.00 & 1.20 & 2 & $\mathrm{R}$ \\
\hline 283 & UT & MEADOW & SMALL BOY* & 620714 & 0.17 & 1.00 & 24.00 & 3.60 & 2 & $\mathrm{R}$ \\
\hline 2003 & UT & MIDDLETON & ANNIE & 530317 & 11.95 & 2.10 & 3.30 & 0.33 & 2 & $\mathrm{R}$ \\
\hline 2003 & UT & MIDDLETON & HARRY & 530519 & 39.47 & 1.92 & 3.80 & 0.38 & 5 & $\mathrm{R}$ \\
\hline 2003 & UT & MIDDLETON & PRISCILLA & 570624 & 0.07 & 1.45 & 10.00 & 1.00 & 2 & $\mathrm{R}$ \\
\hline 2003 & UT & MIDDLETON & SIMON & 530425 & 1.00 & 1.40 & 13.49 & 1.35 & 4 & I \\
\hline 2003 & UT & MIDDLETON & SMOKY & 570831 & 5.37 & 1.81 & 7.00 & 0.70 & 4 & $\mathrm{R}$ \\
\hline 2003 & UT & MIDDLETON & TESLA & 550301 & 2.46 & 1.68 & 10.31 & 1.03 & 3 & I \\
\hline 2003 & UT & MIDDLETON & ZUCCHINI & 550515 & 1.31 & 2.30 & 3.86 & 0.39 & 4 & I \\
\hline 425 & UT & MIDWAY & SMALL BOY & 620714 & 0.10 & 1.40 & 35.00 & 5.25 & 4 & I \\
\hline 124 & UT & MILFORD & APPLE-2 & 550505 & 0.12 & 1.00 & 11.00 & 1.65 & 1 & $\mathrm{R}$ \\
\hline 124 & UT & MILFORD & FOX & 520525 & 0.86 & 1.40 & 14.05 & 1.40 & 4 & $I$ \\
\hline 124 & UT & MILFORD & MET & 550415 & 2.37 & 1.34 & 6.39 & 0.64 & 3 & $\mathrm{R}$ \\
\hline 124 & UT & MILFORD & TURK & 550307 & 0.13 & 1.00 & 16.10 & 1.61 & 1 & $\mathrm{R}$ \\
\hline 125 & UT & MINERSVILLE & FOX & 520525 & 2.71 & 1.40 & 13.96 & 1.40 & 4 & I \\
\hline 125 & UT & MINERSVILLE & MET & 550415 & 5.14 & 1.08 & 6.00 & 0.60 & 3 & $\mathrm{R}$ \\
\hline 933 & UT & MODENA & APPLE-I & 550329 & 0.87 & 1.16 & 5.00 & 0.50 & 2 & $\mathrm{R}$ \\
\hline
\end{tabular}




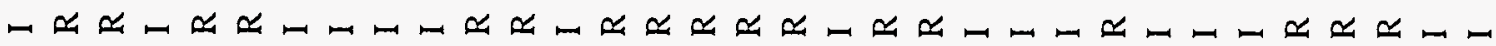

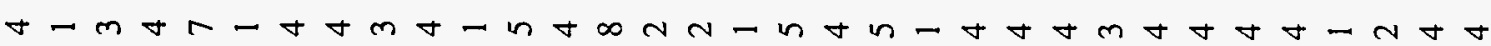

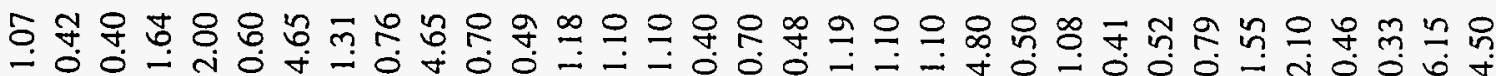

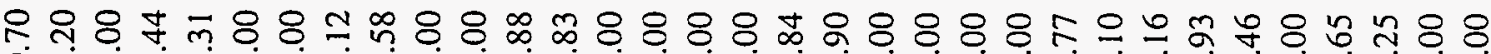

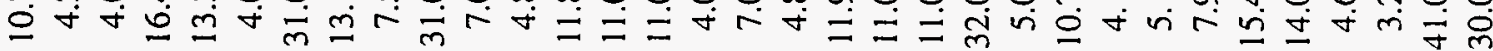

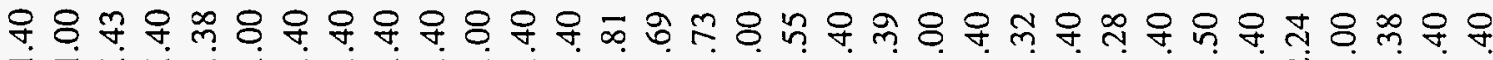

倠

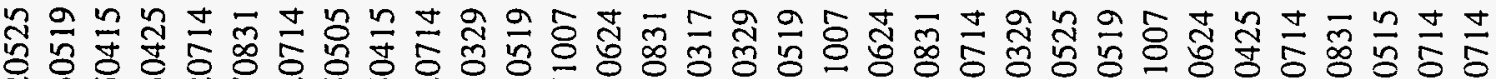

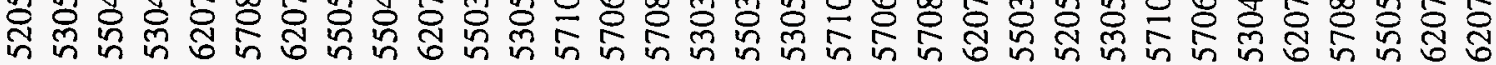

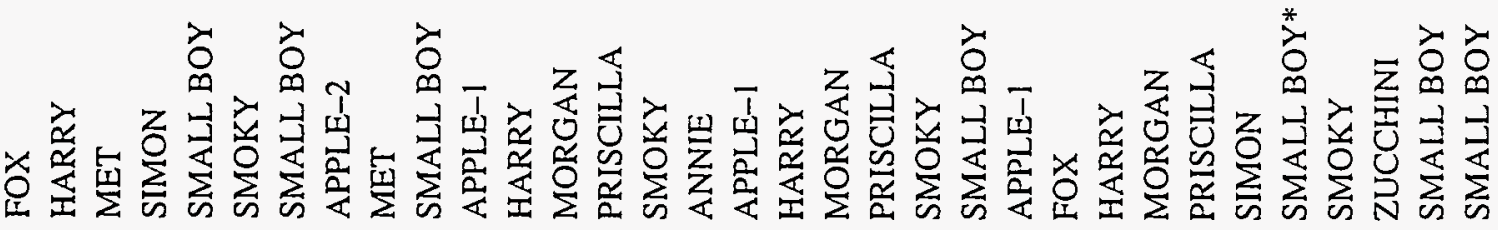
으으으으은

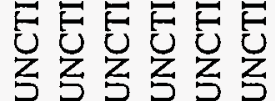

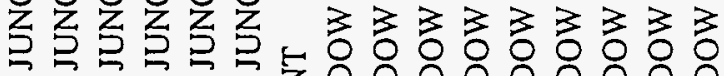

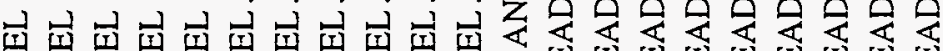

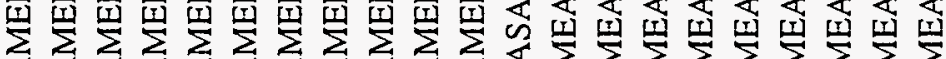

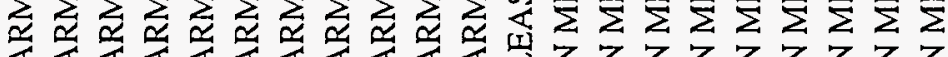

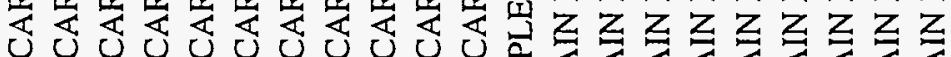

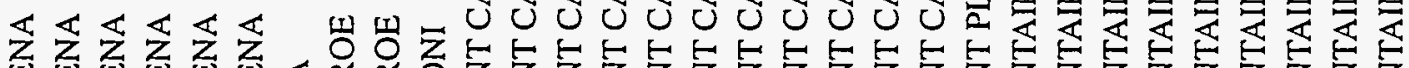

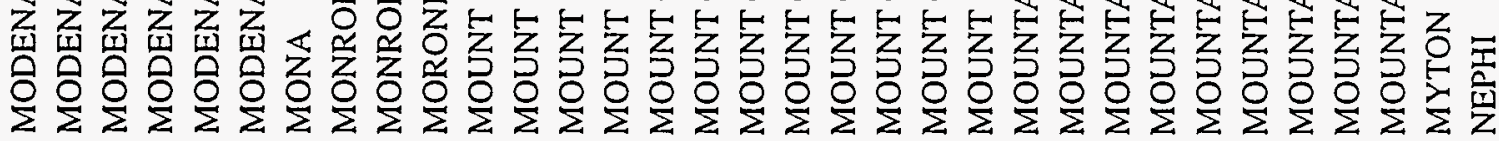

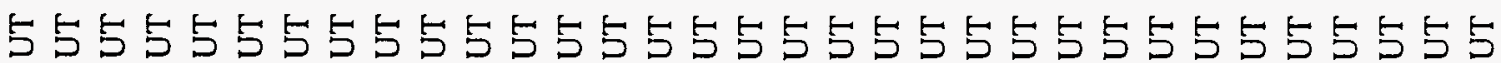

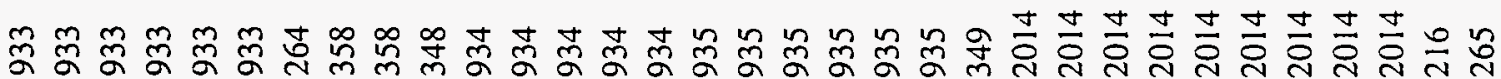




\begin{tabular}{|c|c|c|}
\hline Cntrl & State & Locale \\
\hline 437 & UT & NEW HARMONY \\
\hline 437 & UT & NEW HARMONY \\
\hline 437 & UT & NEW HARMONY \\
\hline 437 & UT & NEW HARMONY \\
\hline 437 & UT & NEW HARMONY \\
\hline 437 & UT & NEW HARMONY \\
\hline 936 & UT & NEWCASTLE \\
\hline 936 & UT & NEWCASTLE \\
\hline 936 & UT & NEWCASTLE \\
\hline 936 & UT & NEWCASTLE \\
\hline 936 & UT & NEWCASTLE \\
\hline 936 & UT & NEWCASTLE \\
\hline 287 & UT & OAK CITY \\
\hline 287 & UT & OAK CITY \\
\hline 375 & UT & OAKLEY \\
\hline 273 & UT & ORDERVILLE \\
\hline 273 & UT & ORDERVILLE \\
\hline 273 & UT & ORDERVILLE \\
\hline 273 & UT & ORDERVILLE \\
\hline 273 & UT & ORDERVILLE \\
\hline 406 & UT & OREM \\
\hline 240 & UT & PANGUITCH \\
\hline 240 & UT & PANGUITCH \\
\hline 257 & UT & PARAGONAH \\
\hline 257 & UT & PARAGONAH \\
\hline 257 & UT & PARAGONAH \\
\hline 257 & UT & PARAGONAH \\
\hline 377 & UT & PARK CITY \\
\hline 258 & UT & PAROWAN \\
\hline 258 & UT & PAROWAN \\
\hline 258 & UT & PAROWAN \\
\hline 258 & UT & PAROWAN \\
\hline 258 & UT & PAROWAN \\
\hline
\end{tabular}

$\begin{array}{lll}\text { Event } & \text { YYMMDD } & \mathrm{H} 12\end{array}$

H12D

$\begin{array}{llll}T A & T A D & \text { NP } & \text { Orig }\end{array}$

$\begin{array}{lrrrrrrl}\text { APPLE-1 } & 550329 & 1.52 & 1.13 & 6.00 & 0.60 & 5 & \mathrm{R} \\ \text { MORGAN } & 571007 & 0.28 & 1.40 & 6.81 & 0.68 & 4 & \mathrm{I} \\ \text { PRISCILLA } & 570624 & 1.00 & 1.40 & 9.82 & 0.98 & 4 & \mathrm{I} \\ \text { SMOKY } & 570831 & 12.10 & 1.40 & 5.45 & 0.54 & 4 & \mathrm{I} \\ \text { TESLA } & 550301 & 0.50 & 1.40 & 13.23 & 1.32 & 3 & \mathrm{I} \\ \text { ZUCCHINI } & 550515 & 1.04 & 1.40 & 3.95 & 0.39 & 4 & \mathrm{I} \\ \text { APPLE-1 } & 550329 & 3.95 & 1.32 & 5.48 & 0.55 & 2 & \mathrm{R} \\ \text { FOX } & 520525 & 1.18 & 1.40 & 11.37 & 1.14 & 4 & \mathrm{I} \\ \text { HARRY } & 530519 & 6.51 & 1.27 & 4.51 & 0.45 & 4 & \mathrm{I} \\ \text { PRISCILLA } & 570624 & 0.39 & 1.36 & 12.00 & 1.20 & 5 & \mathrm{R} \\ \text { SMOKY } & 570831 & 0.72 & 1.00 & 4.75 & 0.47 & 1 & \mathrm{R} \\ \text { ZUCCHINI } & 550515 & 0.15 & 1.40 & 3.46 & 0.35 & 3 & \mathrm{I} \\ \text { APPLE-2 } & 550505 & 1.01 & 1.40 & 14.40 & 1.44 & 4 & \mathrm{I} \\ \text { HOOD } & 570705 & 0.20 & 1.95 & 12.00 & 1.20 & 2 & \mathrm{R} \\ \text { SMALL BOY } & 620714 & 0.11 & 1.40 & 37.00 & 5.55 & 4 & \mathrm{I} \\ \text { APPLE-1 } & 550329 & 0.59 & 1.00 & 7.00 & 0.70 & 1 & \mathrm{R} \\ \text { HARRY } & 530519 & 23.47 & 1.80 & 4.91 & 0.49 & 4 & \mathrm{R} \\ \text { MORGAN } & 571007 & 0.12 & 1.40 & 11.86 & 1.19 & 4 & \mathrm{I} \\ \text { PRISCILLA } & 570624 & 0.83 & 1.42 & 10.50 & 1.05 & 5 & \mathrm{R} \\ \text { SMOKY } & 570831 & 0.46 & 1.95 & 11.50 & 1.15 & 3 & \mathrm{R} \\ \text { SMALL BOY } & 620714 & 0.10 & 1.40 & 33.00 & 4.95 & 3 & \mathrm{I} \\ \text { FOX } & 520525 & 0.77 & 1.40 & 14.46 & 1.45 & 4 & \mathrm{I} \\ \text { SMOKY } & 570831 & 15.58 & 1.14 & 11.92 & 1.19 & 7 & \mathrm{R} \\ \text { FOX } & 520525 & 1.50 & 1.40 & 13.84 & 1.38 & 4 & \mathrm{I} \\ \text { MET } & 550415 & 0.44 & 1.00 & 5.00 & 0.50 & 1 & \mathrm{R} \\ \text { SMOKY } & 570831 & 0.35 & 1.17 & 10.00 & 1.50 & 3 & \mathrm{R} \\ \text { ZUCCHINI } & 550515 & 4.49 & 1.00 & 5.00 & 0.50 & 1 & \mathrm{R} \\ \text { SMALL BOY } & 620714 & 0.10 & 1.40 & 36.00 & 5.40 & 3 & \mathrm{I} \\ \text { FOX } & 520525 & 1.49 & 1.40 & 13.58 & 1.36 & 4 & \mathrm{I} \\ \text { MET } & 550415 & 0.10 & 1.00 & 5.00 & 0.50 & 1 & \mathrm{R} \\ \text { SMALL BOY } & 620714 & 0.06 & 1.24 & 19.00 & 2.85 & 3 & \mathrm{R} \\ \text { SMOKY } & 570831 & 0.41 & 1.00 & 10.50 & 1.58 & 1 & \mathrm{R} \\ \text { ZUCCHINI } & 550515 & 5.30 & 1.00 & 4.68 & 0.47 & 1 & \mathrm{R}\end{array}$




\begin{tabular}{|c|c|c|c|c|c|c|c|c|c|c|}
\hline Cntrl & State & Locale & Event & YYMMDD & $\mathrm{H} 12$ & $\mathrm{H} 12 \mathrm{D}$ & $\mathrm{TA}$ & TAD & NP & Orig \\
\hline 961 & UT & PINE VALLEY & APPLE-1 & 550329 & 0.44 & 1.40 & 5.76 & 0.58 & 4 & I \\
\hline 961 & UT & PINE VALLEY & HARRY & 530519 & 43.93 & 1.05 & 4.06 & 0.41 & 4 & I \\
\hline 961 & UT & PINE VALLEY & MORGAN & 571007 & 0.50 & 1.40 & 6.73 & 0.67 & 4 & I \\
\hline 961 & UT & PINE VALLEY & PRISCILLA & 570624 & 4.17 & 1.14 & 7.71 & 0.77 & 4 & I \\
\hline 961 & UT & PINE VALLEY & SIMON & 530425 & 1.00 & 1.40 & 14.97 & 1.50 & 3 & $I$ \\
\hline 961 & UT & PINE VALLEY & SMOKY & 570831 & 10.06 & 1.29 & 4.90 & 0.49 & 4 & I \\
\hline 961 & UT & PINE VALLEY & TESLA & 550301 & 0.47 & 1.40 & 11.78 & 1.18 & 4 & I \\
\hline 961 & UT & PINE VALLEY & ZUCCHINI & 550515 & 1.19 & 1.40 & 3.63 & 0.36 & 4 & I \\
\hline 965 & UT & PINTO & APPLE-1 & 550329 & 2.02 & 1.40 & 5.67 & 0.57 & 4 & I \\
\hline 965 & UT & PINTO & FOX & 520525 & 0.39 & 1.40 & 11.11 & 1.11 & 4 & I \\
\hline 965 & UT & PINTO & HARRY & 530519 & 20.24 & 1.28 & 4.24 & 0.42 & 4 & I \\
\hline 965 & UT & PINTO & MORGAN & 571007 & 0.16 & 1.40 & 5.45 & 0.55 & 4 & I \\
\hline 965 & UT & PINTO & PRISCILLA & 570624 & 1.39 & 1.40 & 8.83 & 0.88 & 4 & I \\
\hline 965 & UT & PINTO & SMOKY & 570831 & 2.54 & 1.40 & 4.80 & 0.48 & 4 & I \\
\hline 965 & UT & PINTO & ZUCCHINI & 550515 & 1.00 & 1.38 & 3.55 & 0.35 & 4 & I \\
\hline 938 & UT & PINTURA & ANNIE & 530317 & 0.83 & 1.00 & 3.06 & 0.31 & 2 & $\mathrm{R}$ \\
\hline 938 & UT & PINTURA & APPLE-1 & 550329 & 0.24 & 2.71 & 6.00 & 0.60 & 2 & $\mathrm{R}$ \\
\hline 938 & UT & PINTURA & HARRY & 530519 & 25.98 & 1.23 & 4.27 & 0.43 & 4 & $\mathrm{R}$ \\
\hline 938 & UT & PINTURA & MORGAN & 571007 & 0.35 & 1.27 & 8.27 & 0.83 & 2 & $\mathrm{R}$ \\
\hline 938 & UT & PINTURA & PRISCILLA & 570624 & 1.46 & 1.50 & 9.03 & 0.90 & 19 & $\mathbf{R}$ \\
\hline 938 & UT & PINTURA & SMOKY & 570831 & 17.25 & 1.18 & 6.06 & 0.61 & 9 & $\mathrm{R}$ \\
\hline 938 & UT & PINTURA & TESLA & 550301 & 0.98 & 1.42 & 12.52 & 1.25 & 4 & I \\
\hline 938 & UT & PINTURA & ZUCCHINI & 550515 & 1.58 & 1.00 & 4.07 & 0.41 & 1 & $\mathrm{R}$ \\
\hline 937 & UT & PIUTE INDIAN RESERVA & FOX & 520525 & 0.83 & 1.40 & 15.00 & 1.50 & 4 & I \\
\hline 937 & UT & PIUTE INDIAN RESERVA & MET & 550415 & 3.24 & 1.40 & 6.00 & 0.60 & 4 & I \\
\hline 937 & UT & PIUTE INDIAN RESERVA & SMOKY & 570831 & 4.94 & 1.40 & 12.10 & 1.21 & 4 & I \\
\hline 181 & UT & PRICE & SMALL BOY & 620714 & 0.12 & 1.40 & 35.00 & 5.25 & 4 & I \\
\hline 415 & UT & PROVO & SMALL BOY & 620714 & 0.10 & 1.40 & 33.00 & 4.95 & 4 & I \\
\hline 366 & UT & REDMOND & SMALL BOY & 620714 & 0.10 & 1.40 & 28.00 & 4.20 & 4 & 1 \\
\hline 362 & UT & RICHFIELD & APPLE-2 & 550505 & 0.49 & 1.40 & 13.39 & 1.34 & 4 & I \\
\hline 939 & UT & ROCKVILLE & ANNIE & 530317 & 16.13 & 1.57 & 3.94 & 0.39 & 4 & $\mathrm{R}$ \\
\hline 939 & UT & ROCKVILLE & HARRY & 530519 & 42.31 & 1.38 & 4.23 & 0.42 & 3 & $\mathrm{R}$ \\
\hline 939 & UT & ROCKVILLE & PRISCILLA & 570624 & 0.14 & 1.00 & 11.00 & 1.10 & 1 & $\mathrm{R}$ \\
\hline
\end{tabular}




\begin{tabular}{|c|c|c|c|c|c|c|c|c|c|c|}
\hline Cntrl & State & Locale & Event & YYMMDD & $\mathrm{H} 12$ & $\mathrm{H} 12 \mathrm{D}$ & $\mathrm{TA}$ & TAD & $\mathrm{NP}$ & Orig \\
\hline 939 & UT & ROCKVILLE & SMOKY & 570831 & 2.12 & 1.00 & 9.50 & 0.95 & 1 & $\mathrm{R}$ \\
\hline 218 & UT & ROOSEVELT & SMALL BOY & 620714 & 0.47 & 1.40 & 42.00 & 6.30 & 4 & I \\
\hline 409 & UT & SALEM & SMALL BOY & 620714 & 0.12 & 2.19 & 32.00 & 4.80 & 4 & $\mathrm{I}$ \\
\hline 367 & UT & SALINA & SMALL BOY & 620714 & 0.17 & 1.22 & 28.00 & 4.20 & 2 & $\mathrm{R}$ \\
\hline 444 & UT & SANTA CLARA & ANNIE & 530317 & 13.95 & 1.17 & 3.15 & 0.32 & 4 & $\mathrm{R}$ \\
\hline 444 & UT & SANTA CLARA & HARRY & 530519 & 41.77 & 1.15 & 3.67 & 0.37 & 5 & $\mathrm{R}$ \\
\hline 444 & UT & SANTA CLARA & PRISCILLA & 570624 & 0.37 & 1.98 & 9.00 & 0.90 & 3 & $\mathrm{R}$ \\
\hline 444 & UT & SANTA CLARA & SIMON & 530425 & 1.00 & 1.40 & 13.28 & 1.33 & 4 & I \\
\hline 444 & UT & SANTA CLARA & SMOKY & 570831 & 9.76 & 1.31 & 5.63 & 0.56 & 17 & $\mathrm{R}$ \\
\hline 444 & UT & SANTA CLARA & TESLA & 550301 & 4.97 & 1.08 & 9.75 & 0.97 & 4 & $\mathrm{R}$ \\
\hline 444 & UT & SANTA CLARA & ZUCCHINI & 550515 & 0.22 & 2.30 & 3.61 & 0.36 & 2 & $\mathrm{R}$ \\
\hline 410 & UT & SANTAQUIN & SMALL BOY & 620714 & 0.10 & 1.40 & 32.00 & 4.80 & 3 & $I$ \\
\hline 288 & UT & SCIPIO & APPLE-2 & 550505 & 0.86 & 1.40 & 14.33 & 1.43 & 4 & 1 \\
\hline 288 & UT & SCIPIO & HOOD & 570705 & 0.10 & 1.40 & 13.00 & 1.30 & 4 & I \\
\hline 288 & UT & SCIPIO & SMALL BOY & 620714 & 0.17 & 1.00 & 27.00 & 4.05 & 1 & $\mathrm{R}$ \\
\hline 184 & UT & SCOFIELD & SMALL BOY & 620714 & 0.33 & 1.40 & 34.00 & 5.10 & 4 & I \\
\hline 941 & UT & SHIVWITS & ANNIE & 530317 & 25.26 & 2.65 & 3.03 & 0.30 & 7 & $\mathrm{R}$ \\
\hline 941 & UT & SHIVWITS & HARRY & 530519 & 33.42 & 1.62 & 3.58 & 0.36 & 4 & $\mathrm{R}$ \\
\hline 941 & UT & SHIVWITS & PRISCILLA & 570624 & 0.23 & 1.80 & 8.00 & 0.80 & 11 & $\mathrm{R}$ \\
\hline 941 & UT & SHIVWITS & SIMON & 530425 & 1.03 & 1.40 & 13.21 & 1.32 & 4 & I \\
\hline 941 & UT & SHIVWITS & SMOKY & 570831 & 28.97 & 1.28 & 4.71 & 0.47 & 22 & $\mathrm{R}$ \\
\hline 941 & UT & SHIVWITS & TESLA & 550301 & 0.82 & 1.64 & 9.53 & 0.95 & 2 & $\mathrm{R}$ \\
\hline 941 & UT & SHIVWITS & ZUCCHINI & 550515 & 0.97 & 1.10 & 3.37 & 0.34 & 2 & $\mathrm{R}$ \\
\hline 428 & UT & SOLDIER SUMMIT & SMALI BOY & 620714 & 0.93 & 1.32 & 35.00 & 5.25 & 2 & $\mathrm{R}$ \\
\hline 417 & UT & SPANISH FORK & SMALL BOY & 620714 & 0.11 & 2.19 & 33.00 & 4.95 & 4 & I \\
\hline 350 & UT & SPRING CITY & HOOD & 570705 & 0.12 & 1.07 & 15.00 & 2.25 & 2 & $\mathrm{R}$ \\
\hline 350 & UT & SPRING CITY & SMALL BOY & 620714 & 0.17 & 1.40 & 31.00 & 4.65 & 4 & I \\
\hline 438 & UT & SPRINGDALE & ANNIE & 530317 & 7.59 & 2.00 & 3.96 & 0.40 & 3 & $\mathrm{R}$ \\
\hline 438 & UT & SPRINGDALE & HARRY & 530519 & 51.42 & 1.42 & 4.26 & 0.43 & 3 & $\mathrm{R}$ \\
\hline 438 & UT & SPRINGDALE & PRISCILLA & 570624 & 0.10 & 1.00 & 11.00 & 1.65 & 2 & $\mathrm{R}$ \\
\hline 438 & UT & SPRINGDALE & SMOKY & 570831 & 1.83 & 1.23 & 9.50 & 0.95 & 2 & $\mathrm{R}$ \\
\hline 420 & UT & SPRINGVILLE & SMALL BOY & 620714 & 0.12 & 2.19 & 33.00 & 4.95 & 4 & I \\
\hline 443 & UT & ST. GEORGE & ANNIE & 530317 & 6.85 & 1.85 & 3.29 & 0.33 & 45 & $\mathrm{R}$ \\
\hline
\end{tabular}




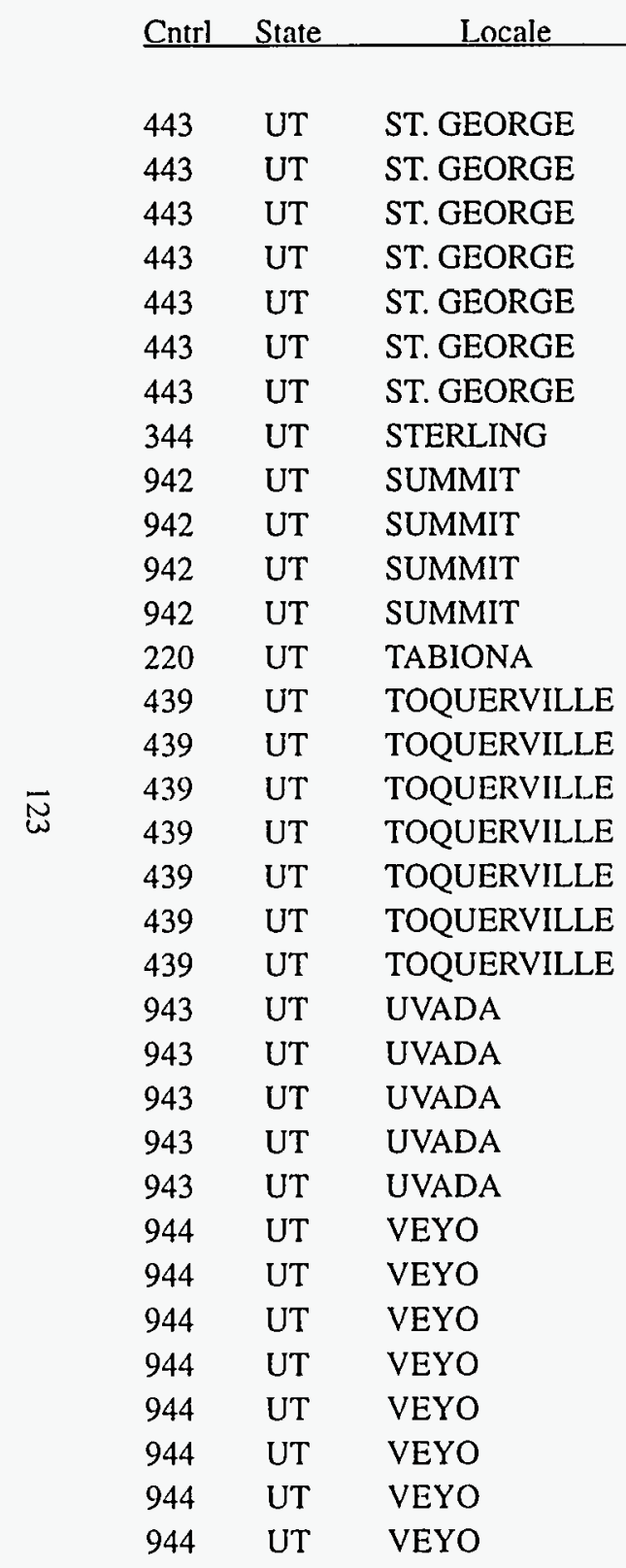

Event

YYMMDD $\quad \mathrm{H} 12$

H12D

TAD NP Orig

$\begin{array}{lrrrrrrl}\text { DIXIE } & 530406 & 0.17 & 1.40 & 9.00 & 1.35 & 2 & \mathrm{R} \\ \text { HARRY } & 530519 & 63.64 & 1.48 & 3.77 & 0.38 & 54 & \mathrm{R} \\ \text { PRISCILLA } & 570624 & 0.26 & 2.56 & 10.00 & 1.00 & 3 & \mathrm{R} \\ \text { SIMON } & 530425 & 0.89 & 1.00 & 13.41 & 1.34 & 1 & \mathrm{R} \\ \text { SMOKY } & 570831 & 6.43 & 1.67 & 6.78 & 0.68 & 15 & \mathrm{R} \\ \text { TESLA } & 550301 & 2.95 & 1.68 & 10.18 & 1.02 & 3 & \mathrm{I} \\ \text { ZUCCHINI } & 550515 & 1.59 & 2.30 & 3.82 & 0.38 & 4 & \mathrm{I} \\ \text { SMALL BOY } & 620714 & 0.11 & 1.40 & 29.00 & 4.35 & 4 & \mathrm{I} \\ \text { APPLE-1 } & 550329 & 0.42 & 1.40 & 6.00 & 0.60 & 4 & \mathrm{I} \\ \text { FOX } & 520525 & 1.12 & 1.40 & 13.16 & 1.32 & 4 & \mathrm{I} \\ \text { SMOKY } & 570831 & 0.36 & 1.10 & 10.00 & 1.50 & 2 & \mathrm{R} \\ \text { ZUCCHINI } & 550515 & 3.24 & 1.40 & 4.42 & 0.44 & 4 & \mathrm{I} \\ \text { SMALL BOY } & 620714 & 1.04 & 1.15 & 38.00 & 5.70 & 2 & \mathrm{R} \\ \text { ANNIE } & 530317 & 0.19 & 1.35 & 3.28 & 0.33 & 2 & \mathrm{R} \\ \text { HARRY } & 530519 & 38.52 & 1.00 & 4.13 & 0.41 & 1 & \mathrm{R} \\ \text { MORGAN } & 571007 & 0.29 & 1.25 & 9.18 & 0.92 & 4 & \mathrm{I} \\ \text { PRISCILLA } & 570624 & 0.97 & 1.15 & 9.92 & 0.99 & 3 & \mathrm{R} \\ \text { SMOKY } & 570831 & 4.37 & 1.00 & 6.83 & 0.68 & 1 & \mathrm{R} \\ \text { TESLA } & 550301 & 0.98 & 1.80 & 11.84 & 1.18 & 3 & \mathrm{R} \\ \text { ZUCCHINI } & 550515 & 1.33 & 1.00 & 4.13 & 0.41 & 1 & \mathrm{R} \\ \text { APPLE-1 } & 550329 & 2.40 & 1.40 & 4.86 & 0.49 & 4 & \mathrm{I} \\ \text { FOX } & 520525 & 4.74 & 1.40 & 10.02 & 1.00 & 4 & \mathrm{I} \\ \text { HARRY } & 530519 & 4.83 & 1.00 & 3.86 & 0.39 & 1 & \mathrm{R} \\ \text { MET } & 550415 & 2.94 & 1.50 & 4.00 & 0.40 & 4 & \mathrm{R} \\ \text { SIMON } & 530425 & 0.98 & 1.40 & 15.12 & 1.51 & 4 & \mathrm{I} \\ \text { ANNIE } & 530317 & 0.16 & 2.85 & 2.50 & 0.38 & 2 & \mathrm{R} \\ \text { APPLE-1 } & 550329 & 0.19 & 1.00 & 5.50 & 0.55 & 1 & \mathrm{R} \\ \text { HARRY } & 530519 & 46.69 & 1.27 & 3.85 & 0.38 & 8 & \mathrm{R} \\ \text { MORGAN } & 571007 & 0.43 & 1.15 & 6.72 & 0.67 & 2 & \mathrm{R} \\ \text { PRISCILLA } & 570624 & 3.96 & 1.25 & 7.30 & 0.73 & 20 & \mathrm{R} \\ \text { SIMON } & 530425 & 1.00 & 1.40 & 14.21 & 1.42 & 4 & \mathrm{I} \\ \text { SMALL BOY } & 620714 & 0.08 & 1.82 & 14.00 & 2.10 & 7 & \mathrm{R} \\ \text { SMOKY } & 570831 & 7.38 & 1.26 & 4.66 & 0.47 & 15 & \mathrm{R}\end{array}$




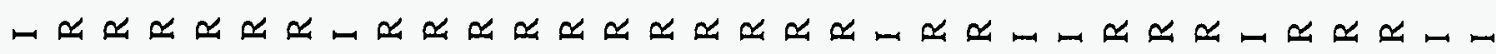

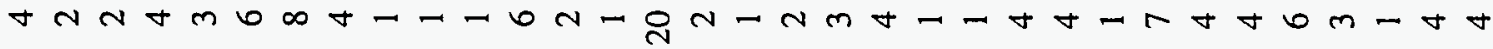

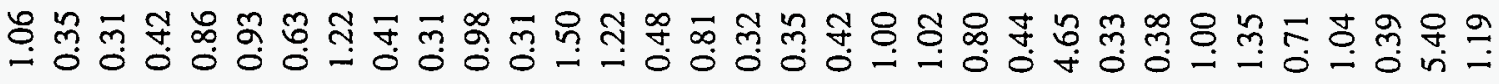

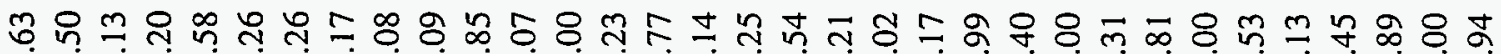

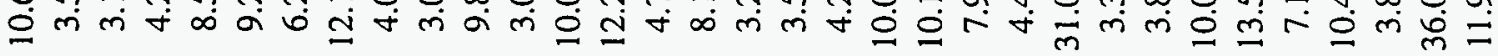

염 음

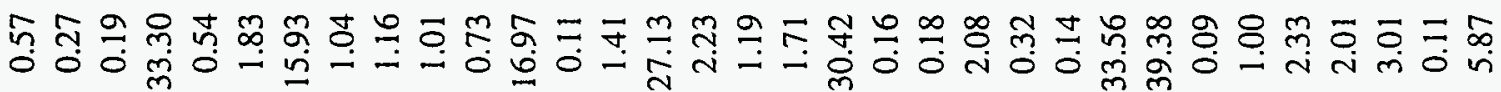

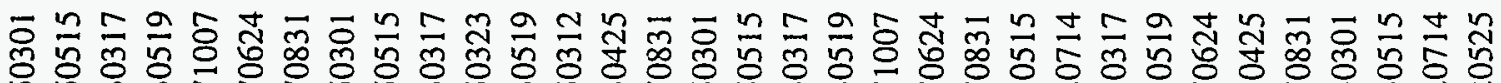

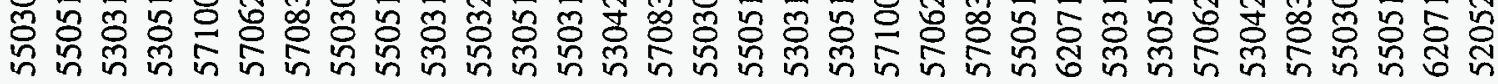

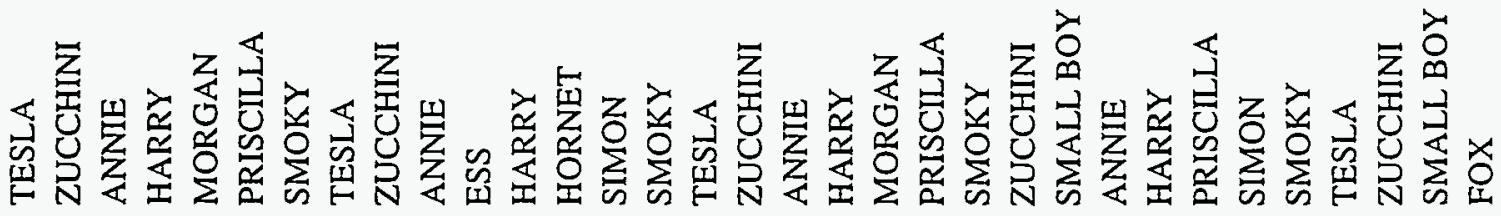

응으응으으응

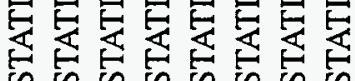

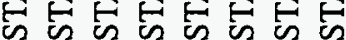

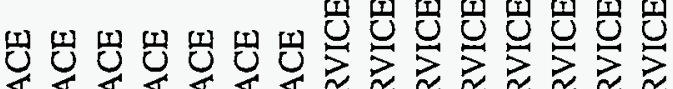

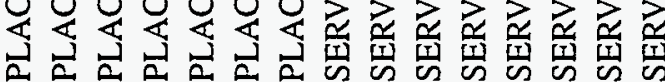

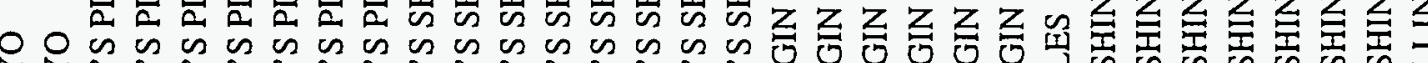

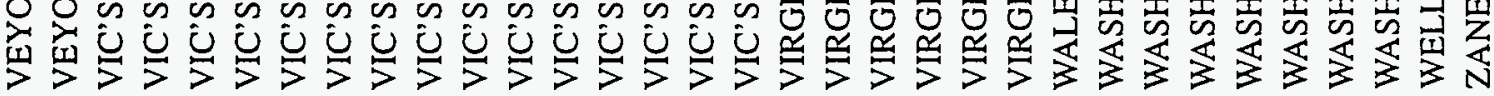

555555555555555555555555555555555

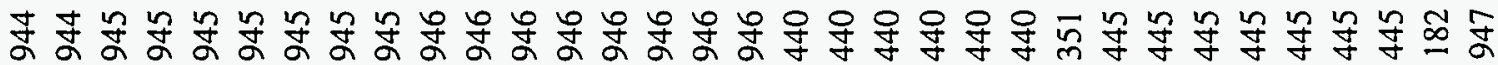




\begin{tabular}{|c|c|c|c|c|c|c|c|c|c|c|}
\hline Cntrl & State & Locale & Event & YYMMDD & $\mathrm{H} 12$ & $\mathrm{H} 12 \mathrm{D}$ & $\mathrm{TA}$ & TAD & NP & Orig \\
\hline 947 & UT & ZANE & MET & 550415 & 5.03 & 1.01 & 5.00 & 0.50 & 2 & $\mathbf{R}$ \\
\hline 947 & UT & ZANE & SMALL BOY & 620714 & 0.10 & 1.40 & 15.02 & 1.50 & 3 & I \\
\hline 948 & UT & ZION LODGE & ANNIE & 530317 & 4.64 & 1.80 & 3.86 & 0.39 & 2 & $\mathbf{R}$ \\
\hline 948 & UT & ZION LODGE & HARRY & 530519 & 41.36 & 1.51 & 4.43 & 0.44 & 5 & R \\
\hline 948 & UT & ZION LODGE & MORGAN & 571007 & 0.18 & 1.40 & 10.75 & 1.08 & 4 & 1 \\
\hline 948 & UT & ZION LODGE & PRISCILLA & 570624 & 0.13 & 1.39 & 10.50 & 1.05 & 4 & $\mathrm{R}$ \\
\hline 948 & UT & ZION LODGE & SMOKY & 570831 & 1.95 & 1.18 & 12.00 & 1.80 & 3 & $\mathrm{R}$ \\
\hline
\end{tabular}




\section{APPENDIX D}

\section{ORERP PROJECT DIRECTIVE NO. 10}

One of 11 project directives of the ORERP, Project Directive No. 10 was issued after discussions with the Dose Assessment Advisory Group in October 1985. Its purpose was to provide interim guidance for dealing with survey-meter readings that were either very low or were made a long time (several days) after the event. The directive is reproduced on the following two pages.

At the time Project Directive No. 10 was issued, the estimation procedure included a weighting scheme based on the time (H+hours) of each measurement. This scheme was subsequently abandoned, making the rules stated in the directive obsolete. As described in the text, the geometric mean and standard deviation were calculated using the arithmetic mean and standard deviation as an intermediate step, whether or not there were net values of 0 . Estimates were always calculated, but they were not included in the final version of the Town Data Base if $X_{E}$ was less than the discernible fallout level. Some measurements were excluded from the calculations if their net value was less than the discernible fallout level, they were taken more than 60 hours after detonation and the net values, decayed to $\mathrm{H}+12$, created an $\mathrm{X}_{\mathrm{E}}$ that was inconsistent with other measurements for that location. 


\section{PROJECT DIRECTIVE NO. 10:}

\section{METHOD OF DEALING WITH "INSIGNIFICANT" EXTERNAL GAMMA EXPOSURE-RATE MEASUREMENTS AND THOSE MADE SEVERAL DAYS AFTER THE EVENT}

\section{BACKGROUND AND GOAL}

The purpose of this directive is to describe a method of dealing with external gamma-exposure-rate measurements that are part of the "Survey-Meter Data Base" and which present one or both of two problems. They are either so low that there is legitimate question whether they are distinguishable from "background" due to radiation from natural background, or they were made so long after the event that the required extrapolation back to $\mathrm{H}+12 \mathrm{~h}$ makes a very low value appear to be large, even if it might be only a background value.

Our previously used methods of dealing with these problems have caused significant difficulty. These methods have consisted of subtracting a background value $(0.02 \mathrm{mR} / \mathrm{h}$, if not otherwise specified) from the measured value, extrapolating the measured value to $\mathrm{H}+12 \mathrm{~h}$ by use of the 11-term exponential relationship, calculating a weighted geometric mean, and a weighted geometric standard deviation. Trouble has arisen particularly when this has resulted in some "zero" values, which makes the usual methods of calculation of geometric means and standard deviations unusable. Attempts to deal with this problem by developing other estimation methods have not been satisfactory, particularly for the calculation of a geometric standard deviation. In addition, these attempts have been very time consuming and are delaying the completion of the "town data base."

Another specific problem concerns the extrapolation of very low measured values back to $H+12 \mathrm{~h}$ when the measurements were made as long as 10 days after the event. This has been reasonably resolved by the use of a weighting factor that is one over the square of the decay correction factor.

These problems were discussed with the Dose Assessment Advisory Group (DAAG) in October 1985. One member of the DAAG recommended that measurements less than 4 times background should be discarded as insignificant and resulting in unmeasurable doses and that measurements made more than 4 days after the event should also be discarded. This proposed solution may be too severe in eliminating potentially usable information. Thus, we are reluctant to implement it without exploring the consequences.

However, we cannot afford to delay the completion of the "town data base" and the directives that follow are interim guidance intended to facilitate completion of the "town data base" and to explore the consequences of following the proposed recommendation.

\section{DIRECTIVES}

1. All measurements of external gamma-exposure rate will be treated in the previous way by subtracting a suitable background from the measured value.

2. If, for a particular location, none of the resulting values are 0 , the weighted geometric mean of the values will be calculated in the usual way. If the weighted geometric mean is less than $0.06 \mathrm{mR} / \mathrm{h}$, no attempt will be made to calculate a geometric standard deviation and it will be specified as "0." 
If the weighted geometric mean is more than $0.06 \mathrm{mR} / \mathrm{h}$, the weighted geometric standard deviation will be calculated in the usual way.

3. If, for a particular location, one or more of the resulting values are 0 , the weighted arithmetic mean will be calculated. If the weighted arithmetic mean is less than $0.06 \mathrm{mR} / \mathrm{h}$, no attempt will be made to calculate an arithmetic standard deviation, a geometric mean, or a geometric standard deviation, and the geometric standard deviation will be specified as " 0. " If the weighted arithmetic mean is more than $0.06 \mathrm{mR} / \mathrm{h}$, the weighted arithmetic standard deviation will be calculated and the geometric mean and the geometric standard deviation will be calculated from these arithmetic values.

4. No measurements will be rejected because of time post detonation. This is because the weighting scheme now used gives very little weight to measurements at late times.

Lynn R. Anspaugh

Scientific Director
Bruce W. Church

Project Manager

Note: Original contains actual signatures 


\section{DISTRIBUTION LIST}

U.S. Department of Energy

B.P. Brooks, EH-421

B.W. Church

D. Elle

J. Fiore

J.S. Ledbetter

M.A. Marelli

S. Mellington

R.V. Nutley

D.L. Wheeler

Technical Information Resource Center

Comprehensive Epidemologic Data Resource

Desert Research Institute

C.B. Thompson (10)

R.D. McArthur

R.L. Jacobson

M.A. Jones

WRC Library

Dose Assessment Advisory Group

E.L. Alpen

J.A. Auxier

C.R. Blincoe

W.J. Breed

G.B. Caldwell

J.E. Carothers

G.W. Casarett

R.L. Coppedge

S. Jablon

J.S. Malik

R.O. McClellan

R.D. Miercort

J.O. Ward

M. Wilde

M.E. Wrenn
ORERP Task Group Leaders

L.R. Anspaugh, Lawrence Livermore

National Laboratory

R. Henderson, Los Alamos National Laboratory

R.F. Smale, Los Alamos National Laboratory

F.W. Whicker, Colorado State University

T.B. Kirchner, Colorado State University

C.E. Steadman, Weather Service

Nuclear Support Office

P.J. Weeden, Environmental Protection Agency

H.L. Beck, Environmental

Measurements Laboratory

P.R. Krey, Environmental

Measurements Laboratory

M. DeMarre, Coordination and

Information Center (60)

\section{Others}

H.N. Friesen, Raytheon Services Nevada

W. Stevens, University of Utah

J.E. Till 